\title{
YEAR 2 BIOMASS UTILIZATION
}

Final Technical Report

(for the period of June 2001 - June 2004)

Prepared for:

AAD Document Control

U.S. Department of Energy

National Energy Technology Laboratory

PO Box 10940, MS 921-107

Pittsburgh, PA 15236-0940

DOE NETL Cooperative Agreement No. DE-FC26-01NT41129

Performance Monitor: Andrew O’Palko

Prepared by:

Christopher J. Zygarlicke

Energy \& Environmental Research Center

University of North Dakota

PO Box 9018

Grand Forks, ND 58202-9018 


\section{EERC DISCLAIMER}

LEGAL NOTICE This research report was prepared by the Energy \& Environmental Research Center (EERC), an agency of the University of North Dakota, as an account of work sponsored by the U.S. Department of Energy (DOE) National Energy Technology Laboratory. Because of the research nature of the work performed, neither the EERC nor any of its employees makes any warranty, express or implied, or assumes any legal liability or responsibility for the accuracy, completeness, or usefulness of any information, apparatus, product, or process disclosed, or represents that its use would not infringe privately owned rights. Reference herein to any specific commercial product, process, or service by trade name, trademark, manufacturer, or otherwise does not necessarily constitute or imply its endorsement or recommendation by the EERC.

\section{DISCLAIMER}

This report was prepared as an account of work sponsored by an agency of the United States Government. Neither the United States Government, nor any agency thereof, nor any of their employees makes any warranty, express or implied, or assumes any legal liability or responsibility for the accuracy, completeness, or usefulness of any information, apparatus, product, or process disclosed or represents that its use would not infringe privately owned rights. Reference herein to any specific commercial product, process, or service by trade name, trademark, manufacturer, or otherwise does not necessarily constitute or imply its endorsement, recommendation, or favoring by the United States Government or any agency thereof. The views and opinions of authors expressed herein do not necessarily state or reflect those of the United States Government or any agency thereof.

This report is available to the public from the National Technical Information Service, U.S. Department of Commerce, 5285 Port Royal Road, Springfield, VA 22161; phone orders accepted at (703) 487-4650.

\section{ACKNOWLEDGMENT}

This report was prepared with the support of the DOE National Energy Technology Laboratory Cooperative Agreement No. DE-FC26-01NT41129. However, any opinions, findings, conclusions, or recommendations expressed herein are those of the author(s) and do not necessarily reflect the views of DOE. 


\section{YEAR 2 BIOMASS UTILIZATION}

\section{ABSTRACT}

This Energy \& Environmental Research Center (EERC) Year 2 Biomass Utilization Final Technical Report summarizes multiple projects in biopower or bioenergy, transportation biofuels, and bioproducts. A prototype of a novel advanced power system, termed the high-temperature air furnace (HITAF), was tested for performance while converting biomass and coal blends to energy. Three biomass fuels - wood residue or hog fuel, corn stover, and switchgrass — and Wyoming subbituminous coal were acquired for combustion tests in the 3-million-Btu/hr system. Blend levels were $20 \%$ biomass $-80 \%$ coal on a heat basis. Hog fuel was prepared for the upcoming combustion test by air-drying and processing through a hammer mill and screen. A K-Tron biomass feeder capable of operating in both gravimetric and volumetric modes was selected as the HITAF feed system. Two oxide dispersion-strengthened (ODS) alloys that would be used in the HITAF high-temperature heat exchanger were tested for slag corrosion rates. An alumina layer formed on one particular alloy, which was more corrosion-resistant than a chromia layer that formed on the other alloy. Research activities were completed in the development of an atmospheric pressure, fluidized-bed pyrolysis-type system called the controlled spontaneous reactor (CSR), which is used to process and condition biomass. Tree trimmings were physically and chemically altered by the CSR process, resulting in a fuel that was very suitable for feeding into a coal combustion or gasification system with little or no feed system modifications required. Experimental procedures were successful for producing hydrogen from biomass using the bacteria Thermotoga, a deep-ocean thermal vent organism. Analytical procedures for hydrogen were evaluated, a gas chromatography (GC) method was derived for measuring hydrogen yields, and adaptation culturing and protocols for mutagenesis were initiated to better develop strains that can use biomass cellulose. Fly ash derived from cofiring coal with waste paper, sunflower hulls, and wood waste showed a broad spectrum of chemical and physical characteristics, according to American Society for Testing and Materials (ASTM) C618 procedures. Higher-than-normal levels of magnesium, sodium, and potassium oxide were observed for the biomass-coal fly ash, which may impact utilization in cement replacement in concrete under ASTM requirements. Other niche markets for biomass-derived fly ash were explored. Research was conducted to develop/optimize a catalytic partial oxidation-based concept for a simple, low-cost fuel processor (reformer). Work progressed to evaluate the effects of temperature and denaturant on ethanol catalytic partial oxidation. A catalyst was isolated that had a yield of 24 mole percent, with catalyst coking limited to less than $15 \%$ over a period of 2 hours. In biodiesel research, conversion of vegetable oils to biodiesel using an alternative alkaline catalyst was demonstrated without the need for subsequent water washing. In work related to biorefinery technologies, a continuous-flow reactor was used to react ethanol with lactic acid prepared from an ammonium lactate concentrate produced in fermentations conducted at the EERC. Good yields of ester were obtained even though the concentration of lactic acid in the feed was low with respect to the amount of water present. Esterification gave lower yields of ester, owing to the lowered lactic acid content of the feed. All lactic acid fermentation from amylose hydrolysate test trials was completed. Management activities included a decision to extend several projects to December 31, 2003, because of delays in receiving biomass feedstocks for testing and acquisition of commercial matching funds. In strategic studies, methods for producing acetate esters for high-value fibers, fuel additives, solvents, and chemical intermediates were discussed with several commercial entities. Commercial industries have an interest in efficient biomass gasification designs but are waiting for economic incentives. Utility, biorefinery, pulp and paper, or other industries are interested in lignin as a potential fuel or feedstock but need more information on properties. 


\section{TABLE OF CONTENTS}

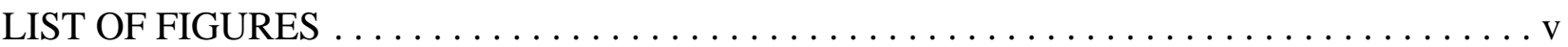

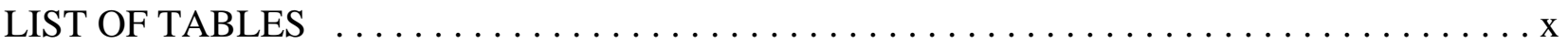

EXECUTIVE SUMMARY $\ldots \ldots \ldots \ldots \ldots \ldots \ldots \ldots \ldots \ldots \ldots \ldots \ldots \ldots \ldots \ldots$ xii

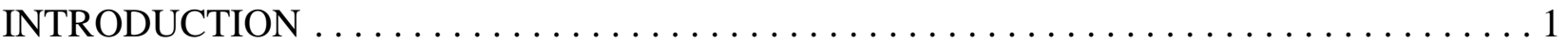

SUBTASK 1.1 - BIOMASS CONVERSION FOR HEAT AND POWER $\ldots \ldots \ldots \ldots \ldots \ldots 3$

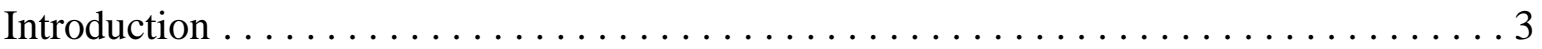

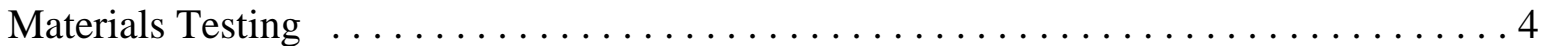

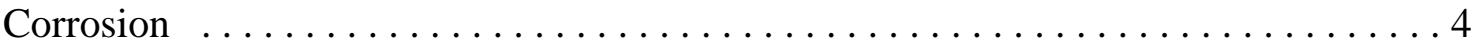

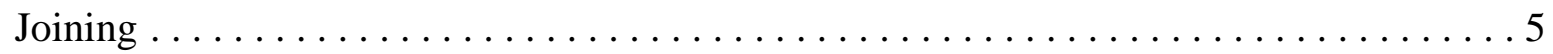

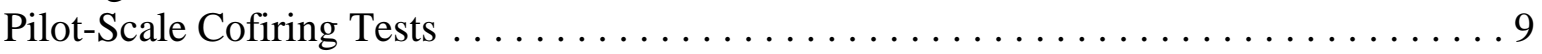

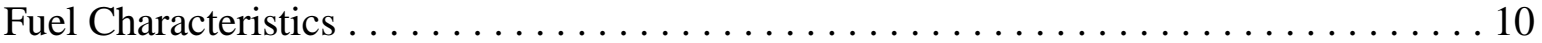

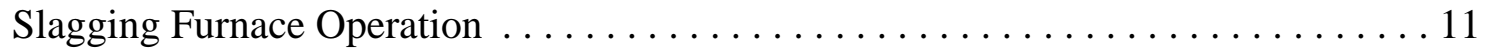

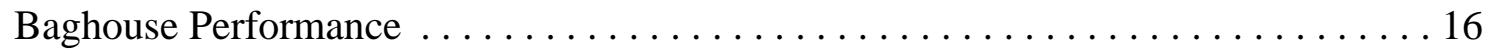

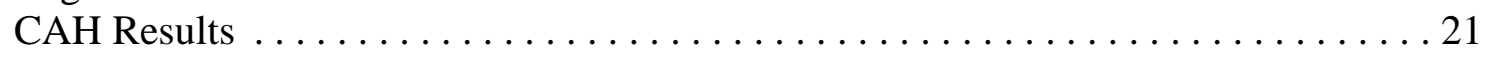

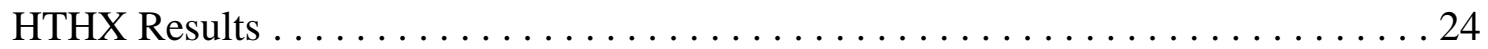

SUBTASK 1.2 - CONTROLLED SPONTANEOUS REACTOR FOR IMPROVING

BIOMASS FEEDING FOR COMBUSTION AND GASIFICATION . . . . . . . . . . . . . 29

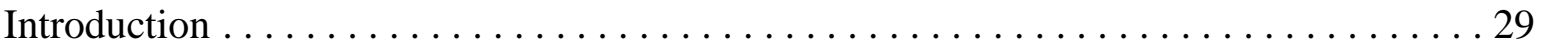

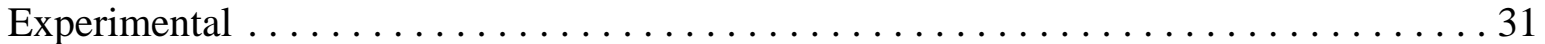

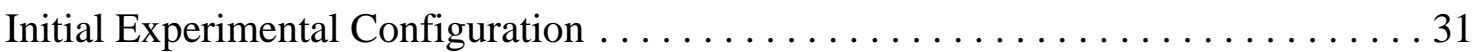

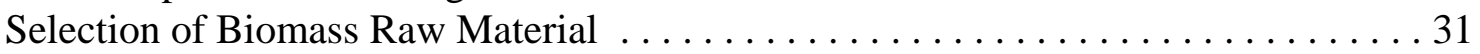

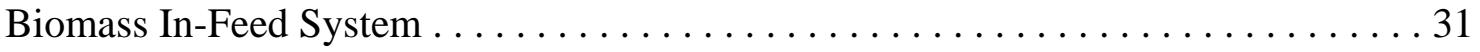

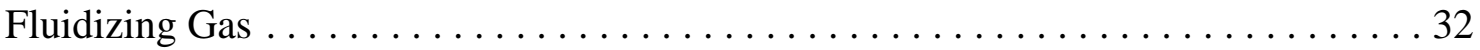

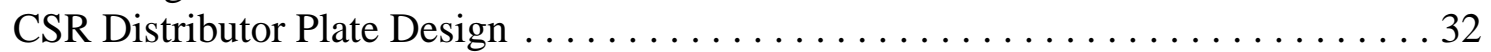

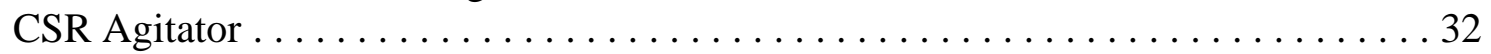

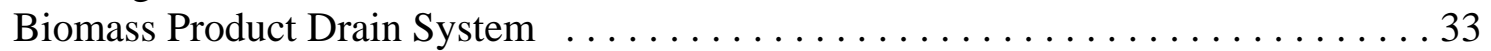

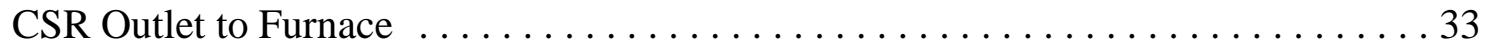

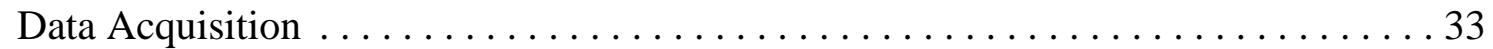

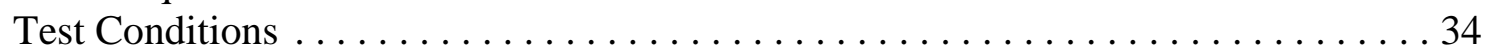

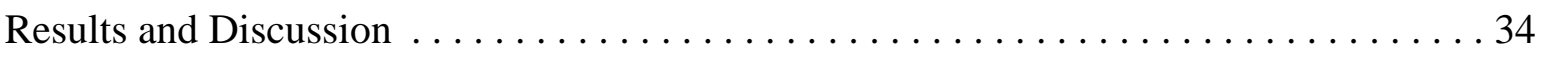

Simulated Rod Mill Size Reduction Testing $\ldots \ldots \ldots \ldots \ldots \ldots \ldots \ldots \ldots \ldots$

Rheological Evaluation of Char-Water Slurries $\ldots \ldots \ldots \ldots \ldots \ldots \ldots \ldots$

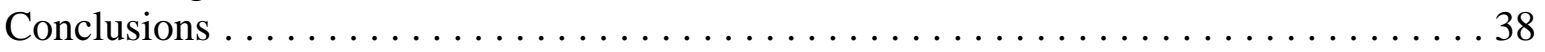

Continued ... 


\section{TABLE OF CONTENTS (continued)}

SUBTASK 1.3 - BIOLOGICAL HYDROGEN PRODUCTION . . . . . . . . . . . . . . 39

Introduction . . . . . . . . . . . . . . . . . . . . . . . . . . . . . . . . . . . . . 39

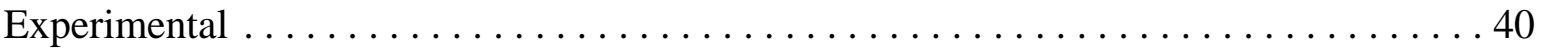

Growth Media ......................................40

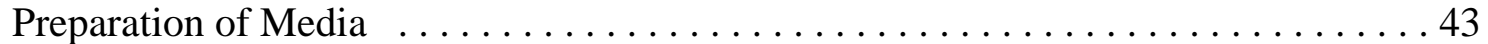

Storage of Cells ..................................... 44

General Procedures .................................. 44

Gas Analysis ...................................... 44

Results and Discussion .................................. 44

Conclusions ........................................... 45

SUBTASK 1.4 - DEVELOPMENT OF MANAGEMENT OPTIONS FOR BIOMASS

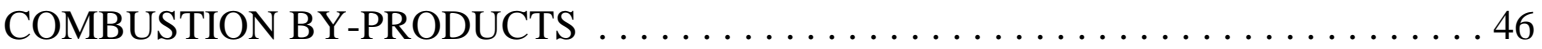

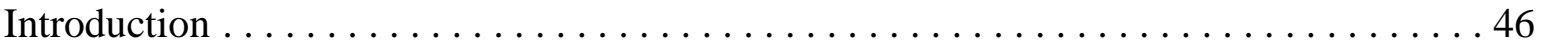

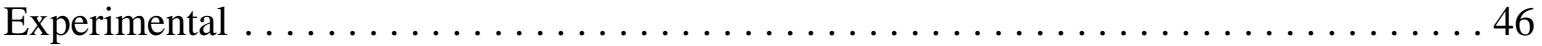

ASTM C618 Chemical Requirements $\ldots \ldots \ldots \ldots \ldots \ldots \ldots \ldots \ldots \ldots \ldots \ldots \ldots$

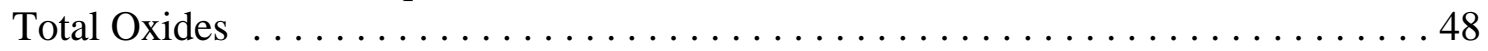

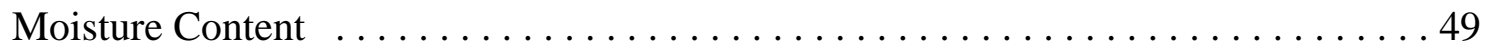

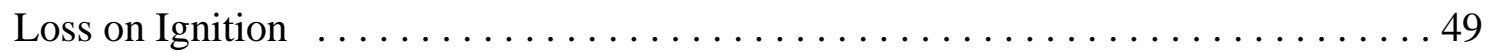

Available Alkalies ...................................... 49

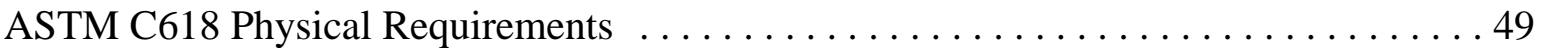

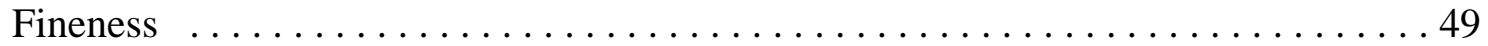

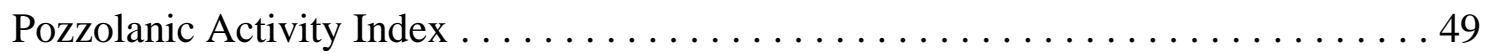

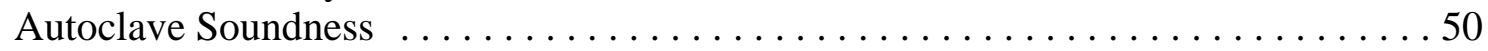

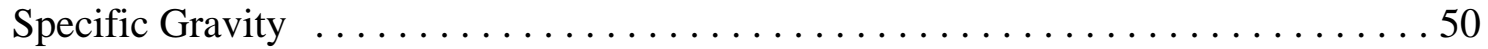

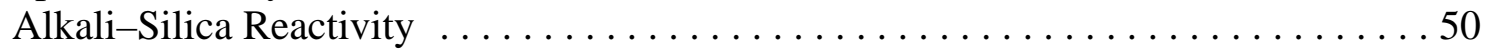

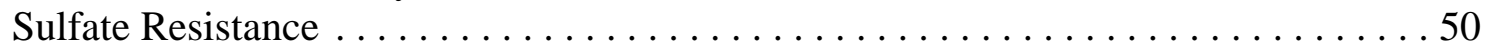

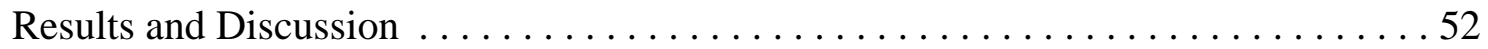

Zeolite Production . . . . . . . . . . . . . . . . . . . . . . . . . . . 57

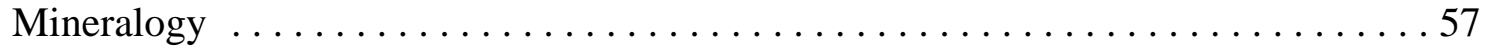

Synthetic Zeolites ................................... 58

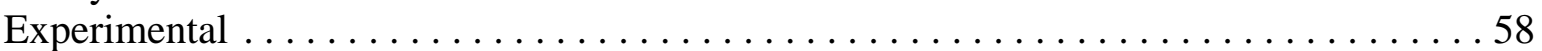

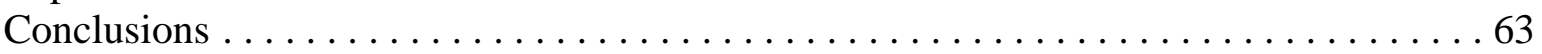

SUBTASK 2.1 - ETHANOL PROCESSING FOR FUEL CELLS $\ldots \ldots \ldots \ldots \ldots \ldots \ldots 6$

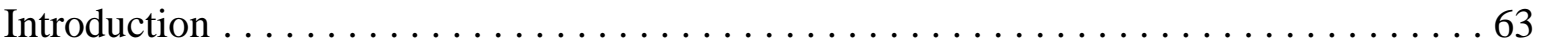

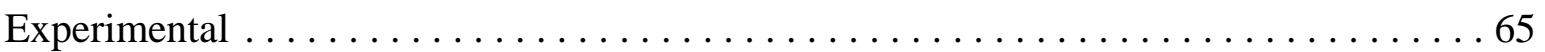

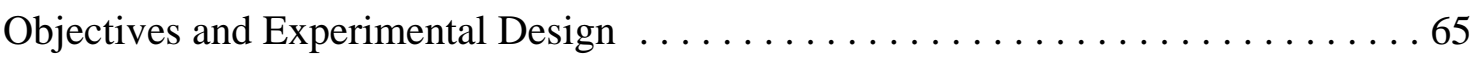

Reactions . .....................................66 66

Description of Materials, Instrumentation, and Equipment $\ldots \ldots \ldots \ldots \ldots \ldots 67$

Continued ... 


\section{TABLE OF CONTENTS (continued)}

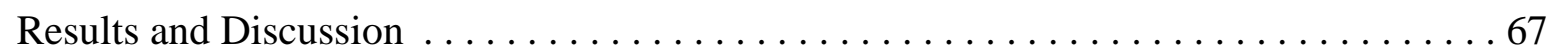

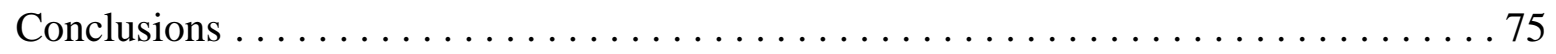

SUBTASK 2.2 - THE USE OF REGIONALLY AVAILABLE WASTE OILS AND AN IMPROVED CATALYST IN THE PREPARATION OF BIODIESEL FUEL . . . . . . 76

SUBTASK 2.3 - ASSESSMENT OF THE USE OF ETHANOL FUELS IN TWO-CYCLE

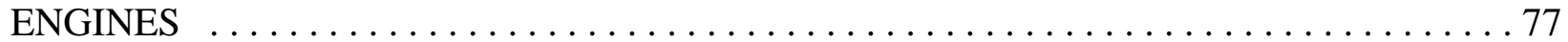

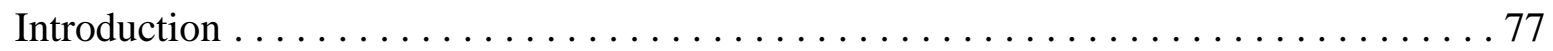

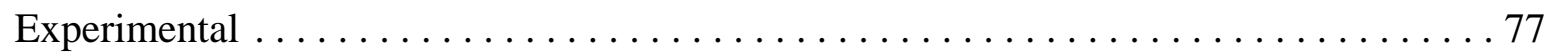

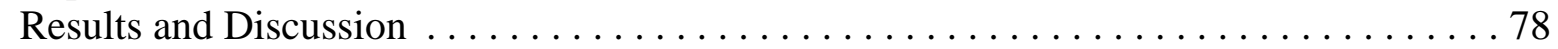

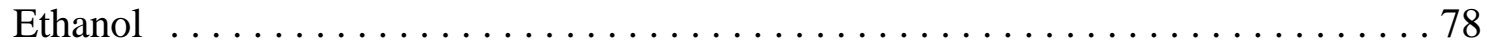

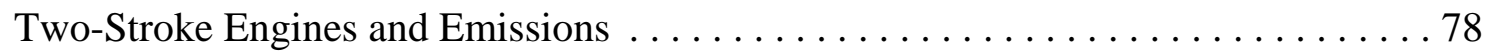

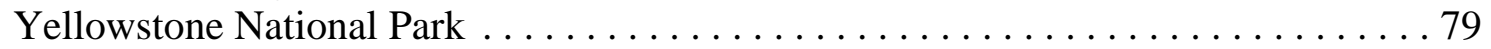

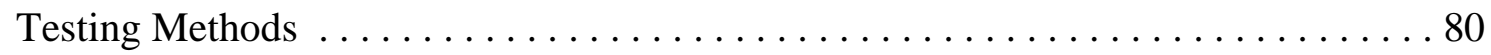

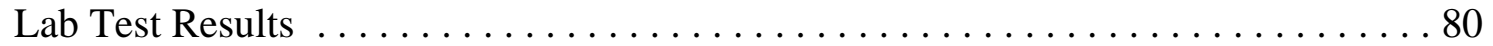

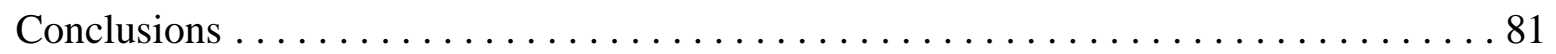

SUBTASK 3.1 - BENCH-SCALE DEMONSTRATION OF ESTERIFICATION

BIOREFINERY ROUTES TO FUEL, SOLVENT, AND CHEMICAL INTERMEDIATE\$I

SUBTASK 3.2 - LACTIC ACID FERMENTATION FROM AMYLOSE

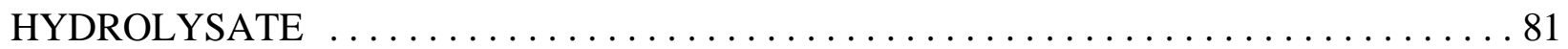

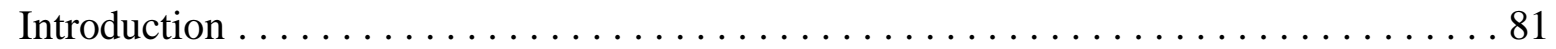

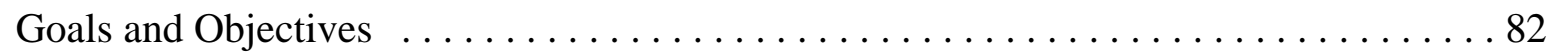

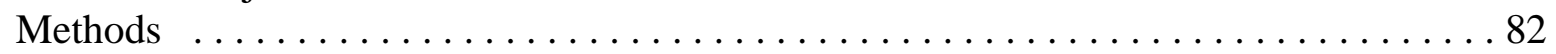

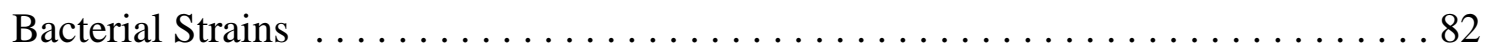

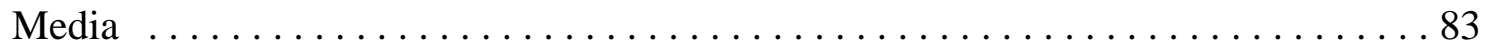

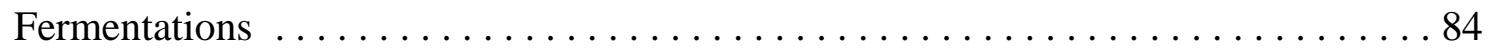

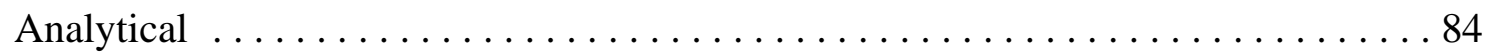

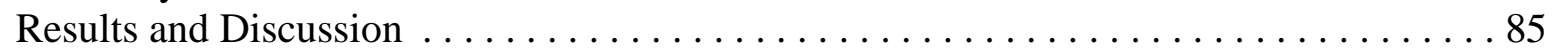

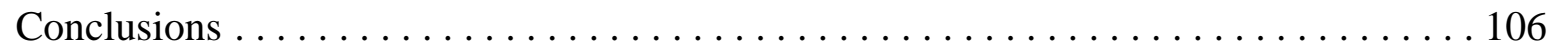

TASK 4.0 - MANAGEMENT AND STRATEGIC STUDIES $\ldots \ldots \ldots \ldots \ldots \ldots \ldots \ldots$

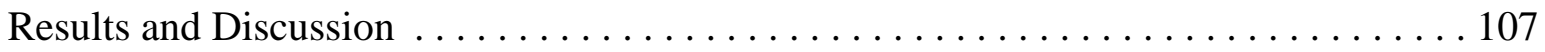

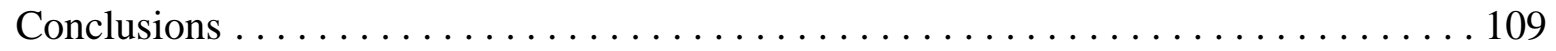

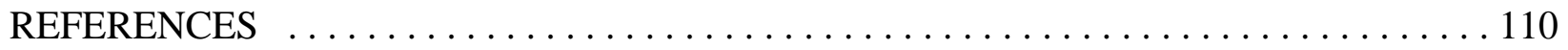

Continued ... 


\section{TABLE OF CONTENTS (continued)}

BIOMASS ASH: AN ANNOTATED BIBLIOGRAPHY $\ldots \ldots \ldots \ldots \ldots \ldots$ Appendix A SUBTASK 1.4 - DEVELOPMENT OF MANAGEMENT OPTIONS FOR BIOMASS COMBUSTION BY-PRODUCTS 


\section{LIST OF FIGURES}

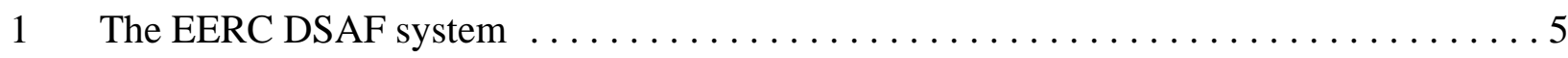

2 The surfaces of the MA956 tube sections after flowing slag corrosion

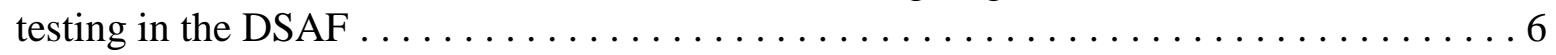

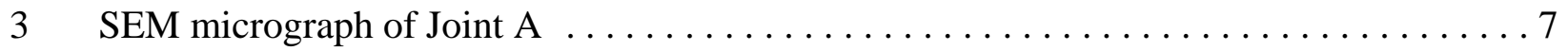

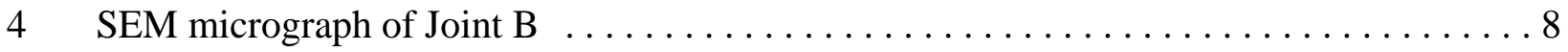

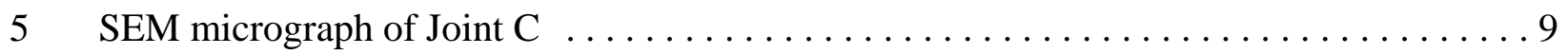

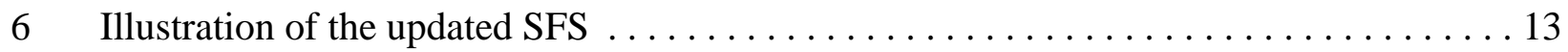

$7 \quad$ Fuel feed rate versus run time for Test SFS-XCEL2-0403 . . . . . . . . . . . . 14

8 Slagging furnace firing rate versus run time for Test SFS-XCEL2-0403 . . . . . . . 15

$9 \quad$ Furnace and slag screen temperatures versus run time for Test SFS-XCEL2-0403 . . . 15

10 Baghouse differential pressure versus run time for Test SFS-XCEL-0403 . . . . . . 17

$11 \mathrm{CAH}$ heat recovery versus run time for the coal-biomass cofiring tests $\ldots \ldots \ldots 22$

12 Photograph of ash deposits on the surface of the tubes following Test XCEL2 . . . . 22

13 Measured and surface area-corrected HTHX heat recovery data for the

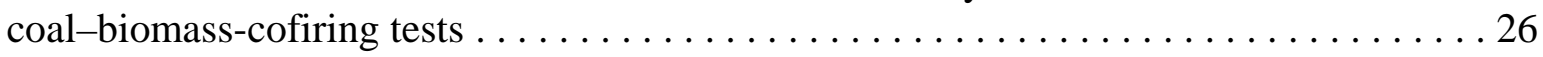

14 Photograph of the HTHX following Test XCEL $2 \ldots \ldots \ldots \ldots \ldots \ldots \ldots \ldots \ldots$

15 HTHX heat recovery (air-blown) versus furnace temperature on an equivalent-

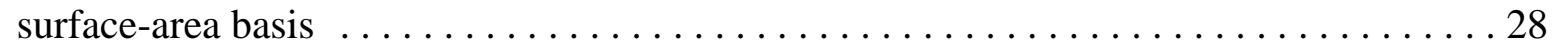

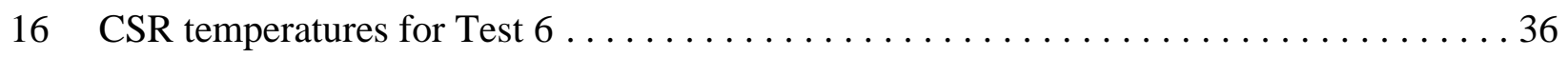

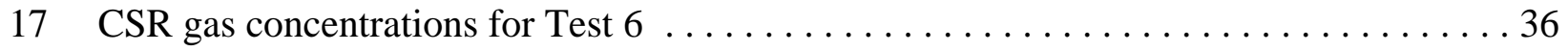

18 Comparison of milling tests performed on the raw unprocessed UWW ( -1 in.) . . . . . 37

Continued ... 


\section{LIST OF FIGURES (continued)}

19 XRD diffractogram of Sample $20-066$ after $48 \mathrm{hr}$ of heating at $150^{\circ} \mathrm{C} \ldots \ldots \ldots 59$

$20 \mathrm{XRD}$ diffractogram of Sample $02-066$ after $48 \mathrm{hr}$ of heating at $150^{\circ} \mathrm{C}$ in a 3 molar

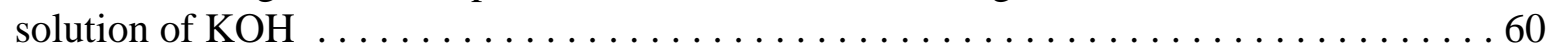

21 XRD diffractogram of Sample $02-066$ after $48 \mathrm{hr}$ of heating at $150^{\circ} \mathrm{C}$ in a 3 molar $\mathrm{NaOH}$

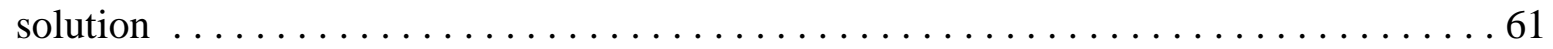

22 Diffractogram of NBS $1633 \mathrm{a}$ after $48 \mathrm{hr}$ at $175^{\circ} \mathrm{C}$ in a 1 molar solution of $\mathrm{NaOH} \ldots \ldots 62$

23 Diffractogram of NBS 1633 a heated for $48 \mathrm{hr}$ at $175^{\circ} \mathrm{C}$ in a $\mathrm{KOH}$ solution $\ldots . . . .662$

24 Effect of partial oxidation on hydrogen production for Catalyst 1, no water addition . . . 68

25 Effect of partial oxidation on hydrogen production for Catalyst 2, no water addition . . . 69

26 Effect of partial oxidation on hydrogen production for Catalyst 3, no water addition . . . 69

27 Comparison of water addition rates on hydrogen production, Catalyst $1 \ldots \ldots \ldots$

28 Comparison of water addition rates on hydrogen production, Catalyst $2 \ldots \ldots \ldots$

29 Comparison of water addition rates on hydrogen production, Catalyst $3 \ldots \ldots$. . . 71

30 Coking rate for Catalyst 1 at varying water addition rates $\ldots \ldots \ldots \ldots \ldots \ldots \ldots$

31 Coking rate for Catalyst 2 at varying water addition rates $\ldots \ldots \ldots \ldots \ldots \ldots \ldots$

32 Coking rate for Catalyst 3 at varying water addition rates $\ldots \ldots \ldots \ldots \ldots \ldots \ldots$

33 Product gas composition for Catalyst $1 \ldots \ldots \ldots \ldots \ldots \ldots \ldots \ldots \ldots \ldots$

34 Comparison of coking rates for various denaturants, Catalyst $1 \ldots \ldots \ldots \ldots$

35 Comparison of coking rates for various denaturants, Catalyst $2 \ldots \ldots \ldots \ldots$

36 Comparison of the coking rates versus temperature, Catalyst $1 \ldots \ldots \ldots \ldots \ldots$

37 Cumulative consumption of 4.3 $\mathrm{M}$ ammonium hydroxide during the fermentation of

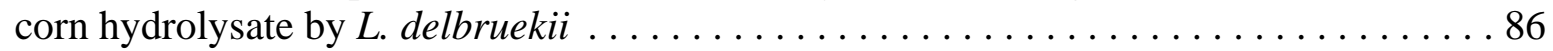




\section{LIST OF FIGURES (continued)}

38 Consumption of carbohydrates in the fermentation of corn hydrolysate by L. delbruekii

39 Total bacteria counts of the fermentation broth during the fermentation of corn

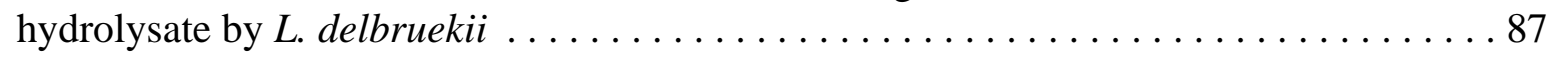

40 Production of fermentation acids L. delbruekii during the fermentation of corn

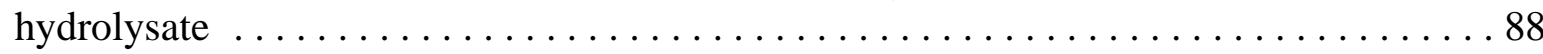

41 Efficiency of fermentation, expressed as the weight of lactic acid produced compared to the initial glucose concentration, during the fermentation of corn hydrolysate

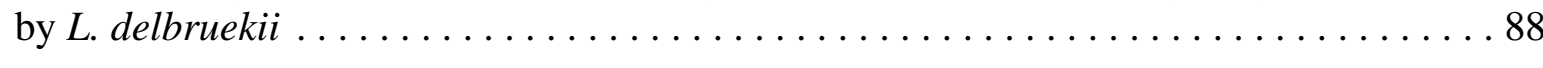

42 Cumulative consumption of $4.3 \mathrm{M}$ ammonium hydroxide during the fermentation

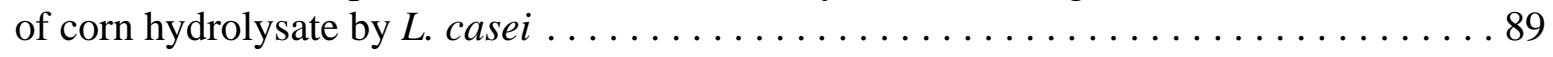

43 Consumption of carbohydrates in the fermentation of corn hydrolysate by L. casei . . . . 89

44 Total bacteria counts of the fermentation broth during the fermentation of corn

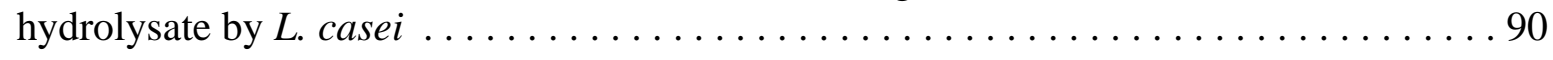

45 Production of fermentation acids by $L$. casei during the fermentation of corn

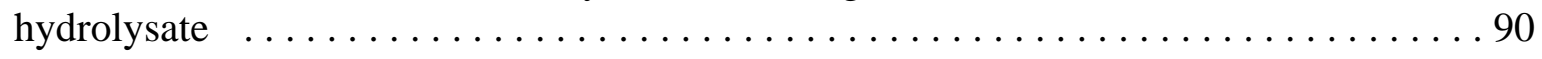

46 Efficiency of fermentation, expressed as the weight of lactic acid produced compared to the initial glucose concentration, during the fermentation of corn hydrolysate

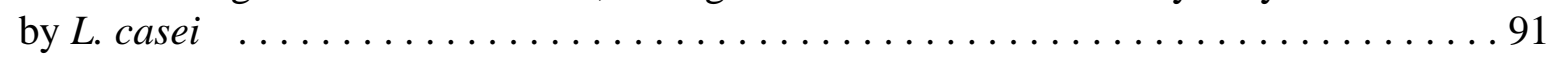

47 Cumulative consumption of 4.3 $\mathrm{M}$ ammonium hydroxide during the fermentation

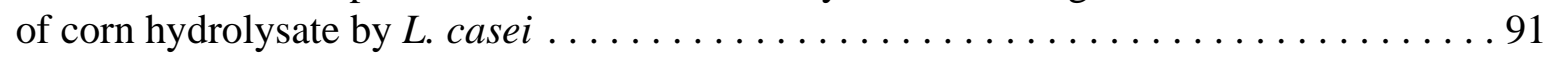

48 Consumption of carbohydrates in the fermentation of corn hydrolysate by L. casei . . . . 92

49 Total bacteria counts of the fermentation broth during the fermentation of corn

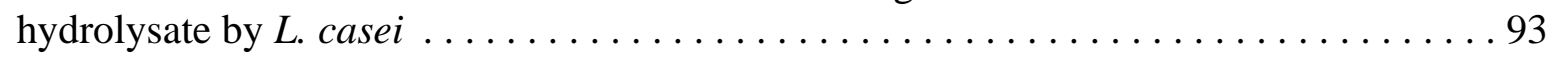

50 Production of fermentation acids by $L$. casei during the fermentation of corn

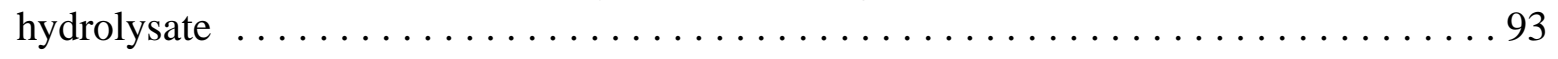

Continued ... 


\section{LIST OF FIGURES (continued)}

51 Efficiency of fermentation, expressed as the weight of lactic acid produced compared to the initial glucose concentration, during the fermentation of corn hydrolysate

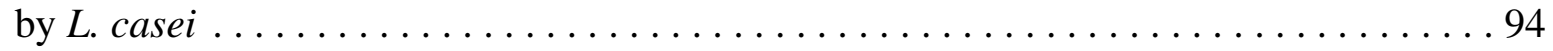

52 Cumulative consumption of 4.3 $\mathrm{M}$ ammonium hydroxide during the fermentation of

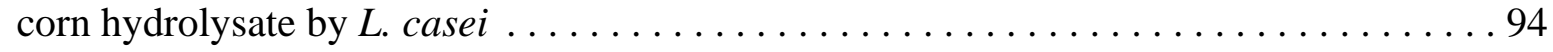

53 Consumption of carbohydrates in the fermentation of corn hydrolysate by L. casei . . . . 95

54 Total bacteria counts of the fermentation broth during the fermentation of corn

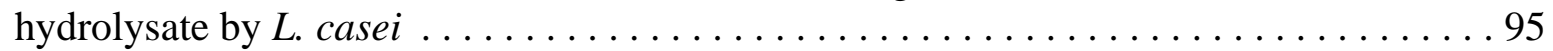

55 Production of fermentation acids by L. casei during the fermentation of corn

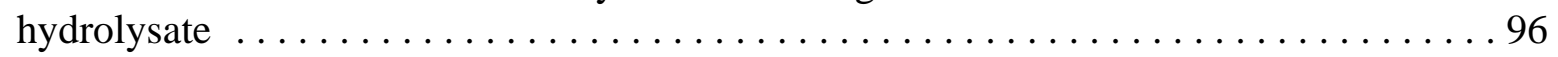

56 Efficiency of fermentation, expressed as the weight of lactic acid produced compared to the initial glucose concentration, during the fermentation of corn hydrolysate by

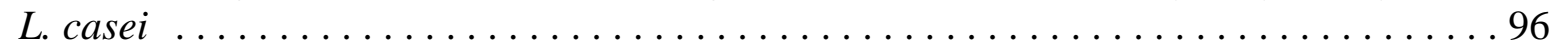

57 Cumulative consumption of 4.3 $\mathrm{M}$ ammonium hydroxide during the fermentation of

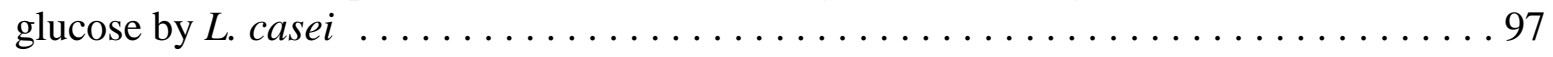

58 Consumption of carbohydrates in the fermentation of glucose by L. casei . . . . . . . . 97

59 Total bacteria counts of the fermentation broth during the fermentation of glucose by

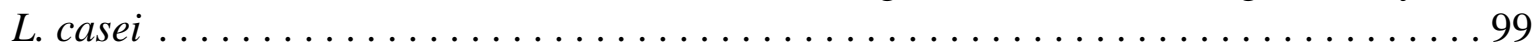

60 Production of fermentation acids by L. casei during the fermentation of glucose . . . . . 99

61 Efficiency of fermentation, expressed as the weight of lactic acid produced compared to the initial glucose concentration, during the fermentation of glucose by L. casei . . . 100

62 Cumulative consumption of 4.3 $\mathrm{M}$ ammonium hydroxide during the fermentation of

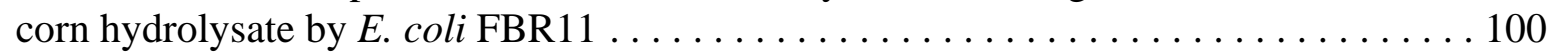

63 Consumption of carbohydrates in the fermentation of corn hydrolysate by E. coli FBR11 101

Continued ... 


\section{LIST OF FIGURES (continued)}

64 Total bacteria counts of the fermentation broth during the fermentation of corn

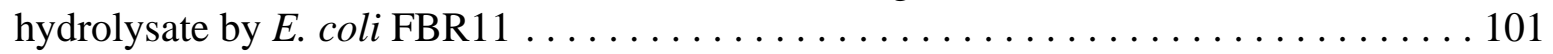

65 Production of fermentation acids by $E$. coli FBR11 during the fermentation of corn

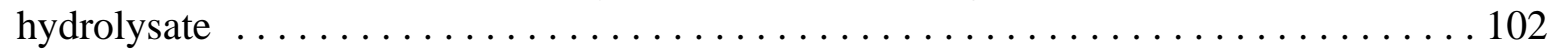

66 Efficiency of fermentation, expressed as the weight of lactic acid produced compared to the initial glucose concentration, during the fermentation of corn hydrolysate by

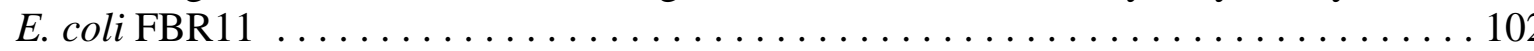

67 Cumulative consumption of 4.3 $\mathrm{M}$ ammonium hydroxide during the fermentation of corn

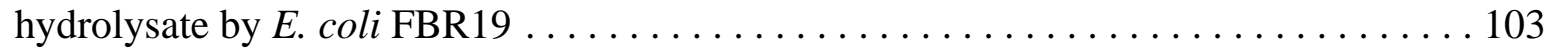

68 Consumption of carbohydrates in the fermentation of corn hydrolysate by E. coli FBR19

69 Total bacteria counts of the fermentation broth during the fermentation of corn

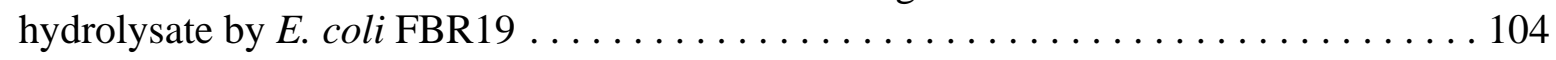

70 Production of fermentation acids by E. coli FBR19 during the fermentation of corn

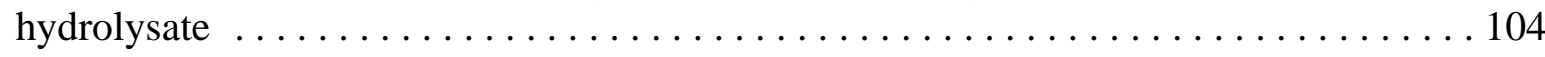

71 Efficiency of fermentation, expressed as the weight of lactic acid produced compared to the initial glucose concentration, during the fermentation of corn hydrolysate by E. coli FBR19 105 


\section{LIST OF TABLES}

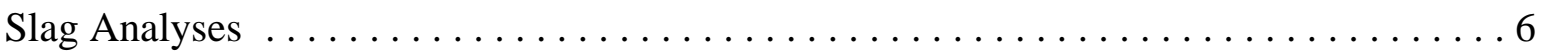

2 Summary of SEM Examinations of the TLP Joints 10

3 Results of Fuel and Fuel Ash Analysis for the Coal-Biomass Cofiring Tests

4 Baghouse Bulk Ash Sample Analyses for Tests XCEL1, XCEL2, XCEL3, and a Previously Fired Subbituminous Coal $\ldots \ldots \ldots \ldots \ldots \ldots \ldots \ldots \ldots \ldots \ldots \ldots \ldots \ldots \ldots$

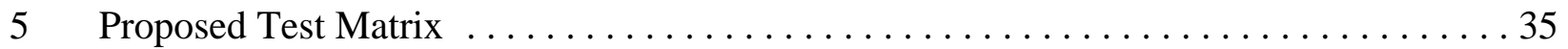

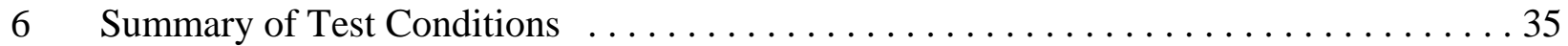

$7 \quad$ ASTM Specification C618-92a Chemical and Physical Specifications . . . . . . . . . . 48

8 Biomass Samples Tested for Alkali-Silica Reactivity . . . . . . . . . . . . . 51

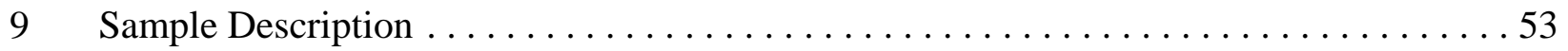

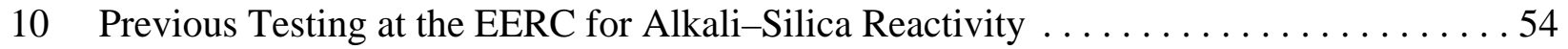

11 Results of Testing Biomass Samples for Alkali-Silica Reactivity . . . . . . . . . . . . 55

12 Average Length Expansions Due to Sulfate Resistance Using Type V Cement . . . . . . 55

13 Average Length Expansions Due to Sulfate Resistance Using Type V Cement . . . . . . 56

14 Average Length Expansions Due to Sulfate Resistance Using Type V Cement . . . . . . 56

15 Length Expansion Results of Testing Biomass Samples for Sulfate Resistance . . . . . . 56

16 Chemical Composition of Full-Scale Biomass-Coal Ash . . . . . . . . . . . . . 58

17 Ethanol cPOX Reforming - Reaction Condition and Catalyst Evaluation .........66

18 Average Product Gas Composition under Catalyst $1 \ldots \ldots \ldots \ldots \ldots \ldots \ldots \ldots$

19 Average Product Gas Composition under Catalyst $2 \ldots \ldots \ldots \ldots \ldots \ldots \ldots$

20 Bacterial Strains Selected for Lactic Acid Production Fermentations . . . . . . . . . 83

Continued ... 


\section{LIST OF TABLES (continued)}

21 Composition of MRS Media for Growth of Lactobacilli (Difco) . . . . . . . . . . . 83

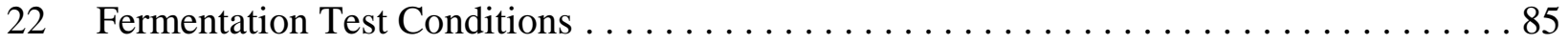

23 Glucose and Lactic Acid Concentrations in the Fermentation Tests . . . . . . . . . 105

24 Lag Periods, Rate of Lactic Acid Production, and Time to Total Glucose

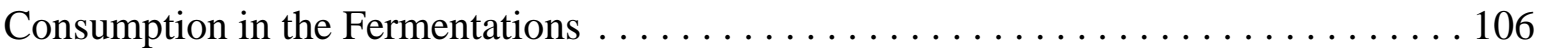




\section{YEAR 2 BIOMASS UTILIZATION}

\section{EXECUTIVE SUMMARY}

This document is a Final Technical Report for multiple project activities under the program entitled "Year 2 Biomass Utilization," U.S. Department of Energy (DOE) Contract DEFC26-01NT41129. The goal of the Energy \& Environmental Research Center (EERC) Biomass Utilization Program is to develop economical, environmentally sound technologies that will promote efficient biopower or bioenergy, transportation biofuels, and bioproducts.

In Subtask 1.1, a novel advanced power system, designed by United Technologies Research Center and termed the high-temperature air furnace (HITAF), is being used at the EERC to convert coal and biomass to clean energy. The heart of the system includes a very hightemperature heat exchanger (HTHX) to produce clean air to turn an aeroderivative turbine. A decision was made to fire one blend level of three biomass fuels with a coal. The first biomass, hog fuel, will be cofired with Powder River Basin (PRB) subbituminous coal from Wyoming at a $20 \%$ hog fuel blend on a heat basis. In preparation for combustion tests on the HITAF system, a truckload of the PRB subbituminous coal (20-25 tons) was delivered and pulverized. Hog fuel was received from the city of Grand Forks and air-dried. Specifications for the biomass feeder that will be added to the slagging furnace were finalized. Based on vendor specifications and quotes, the EERC purchased and installed a K-Tron feeder capable of operating in both gravimetric and volumetric modes. The first coal-biomass cofiring test took place in October 2003. Coal and biomass characterization was performed to prepare the 3-million-Btu/hr slagging furnace system for cofiring tests. The hog fuel contained very high volatile matter, nearly equal ash (4\%), and much higher potassium and calcium contents compared to the coal. Viscosity tests showed hog fuel ash melting at much higher temperatures than the coal, which is critical information for the slagging furnace.

In Subtask 1.2, an atmospheric pressure, fluidized-bed pyrolysis-type system called the controlled spontaneous reactor (CSR) was used to condition and dry tree trimmings, considered a subset of urban wood waste (UWW). This activity was completed in May 2003; therefore, no further activity occurred during this year.

The CSR pilot-scale system was successfully used to physically and chemically alter biomass material, resulting in a fuel that is suitable for feeding into a coal combustion or gasification system operated at either atmospheric or pressurized conditions, with little or no feed system modifications required. Size reduction testing in the CSR showed that the altered CSR biomass product should have very low power requirements for any additional size reduction. While 2.5-cm (1-in.) material was the maximum size capable of being fed into the pilot-scale system, a full-scale commercial system would be expected, with proper design, to easily accommodate larger material up to at least $7.6 \mathrm{~cm}$ (3 in.) in size. Successful operation of the pilot-scale system required limiting the inlet oxygen content for the fluidizing gas to less than $2 \%$. It is expected that operation with higher inlet oxygen concentrations will be possible with a full-scale commercial system. A spouting-bed distributor plate along with mechanical agitation 
was required to maintain fluidization of the biomass within the CSR and to prevent the biomass feed material from intertwining into an immovable mass and eventually into a plug of material. If mechanical agitation is required in a larger-scale system, it could be accomplished with minimal power requirements. The CSR has enough versatility to operate for both combustion and gasification systems.

In Subtask 1.3, experimental procedures were successful for culturing two species of Thermotoga, T. maritima and T. neapolitana, which are deep-ocean thermal vent organisms that use glucose and other carbohydrate sources. Growth was rapid using glucose. Cultures of neapolitana were inoculated into media containing cellulose, cellobiose, starch, and maltose, which are most representative of biomass plant-derived sugars, plus lactose, which is an abundant sugar in dairy waste. Growth of neapolitana was poor in starch, and an alternative media is being tested.

In Subtask 1.4, fly ash derived from cofiring coal with waste paper, sunflower hulls, and wood waste is being evaluated for reuse. Results of all chemical, physical, and engineering testing were assembled, and data interpretation related to the use of biomass-coal ash as a mineral admixture in concrete was completed for inclusion in the final report for this task. Two full-scale ashes were selected based on their availability and chemistry for zeolite production. The samples selected were chosen because of the $\mathrm{K}_{2} \mathrm{O}, \mathrm{Na}_{2} \mathrm{O}$, and $\mathrm{CaO}$ content. These ashes were not suitable for application as a mineral admixture or cement replacement in concrete because of the alkaline content. Several attempts were made to produce zeolites from the selected fly ash samples. The trials included no addition of alkali, potassium hydroxide, or sodium hydroxide. All samples were heated to temperatures ranging from $90^{\circ}$ to $150^{\circ} \mathrm{C}$. In some experiments, the samples were heated under pressure to potentially enhance the zeolite formation. Using the biomass-coal samples, zeolites were not formed in any of the experiments; however, tobermorite, a mineral precursor of zeolites, was formed. Since both samples in these trials had a high calcium content and there were no reports of zeolites being produced from highcalcium ash in the literature, it was preliminarily concluded that different conditions would be required for zeolite formation from high-calcium fly ash as compared to low-calcium fly ash. The first draft of the task's final report was prepared and is under review.

In Subtask 2.1, a catalytic partial oxidation-based concept for reforming ethanol to hydrogen is being pursued. Results were obtained from the evaluation of the effect of denaturant and temperature on hydrogen production that indicate that EtOH denatured with $\mathrm{MeOH}$ provides higher $\mathrm{H}_{2}$ yields than EtOH denatured with regular unleaded gasoline or natural gas liquids. In addition, less catalyst coking occurred than for EtOH containing other denaturants, producing a higher revenue stream while potentially reducing costs of operation by extending the life of the catalyst. While no attempt was made to increase $\mathrm{H}_{2}$ through catalytic water-gas shift, it is clear that the high $\mathrm{CO}$ concentration in all of the streams produced can be decreased to recover additional $\mathrm{H}_{2} \cdot \mathrm{H}_{2}$ concentration doubled when operating temperature was increased up to $755^{\circ} \mathrm{C}$ as did $\mathrm{CH}_{4}$, while $\mathrm{CO}$ nearly doubled. However, coking at the catalyst surface also increased as the temperature increased up to $755^{\circ} \mathrm{C}$. 
In Subtask 2.2, conversion of vegetable oils to biodiesel using an alternative alkaline catalyst without the subsequent water washing was successfully modeled. Verification of the process continued, as well as optimization. Details of the catalyst and process system used will be held confidential until patents are checked.

In Subtask 2.3, an assessment was conducted to determine the technical, environmental, and economic prudence of developing two-stroke engines that run on ethanol-gasoline blends. The use of E10 (10\% ethanol)-blended fuels shows significant reductions in emissions, with E85 (85\% ethanol) showing even more dramatic reductions in emissions. More engines need to be tested, and durability tests should be performed to instill confidence in consumers. Consumers need to be educated about the advantages of using E85. The combinations of technological innovations and the use of ethanol could conceivably reduce two-stroke engine emissions by significantly large amounts. It is important to remember that these results could be expected in all two-cycle engines, including snowmobiles, personal watercraft, outboard motors, motorcycles, all terrain vehicles, lawnmowers, chainsaws, weed trimmers, electrical generators, compressors, pressure washers, mopeds, and scooters. With the growing population and the number of engines increasing every year, these emission problems will not go away. There are an estimated 2.7 million snowmobiles registered, and this number increases every year. Education and more testing will be needed to overcome the problems of lack of availability of E85.

In Subtask 3.1, a continuous-flow reactor is being used to react ethanol with lactic acid prepared from an ammonium lactate concentrate produced in fermentations conducted at the EERC for demonstration of a dual-fermentation biorefinery (DFB) process. The principal investigator in charge of experimental data collection for this project underwent major surgery, and work will resume on this project in the last quarter. Work performed to date shows good yields of ester even though the concentration of lactic acid in the feed was low with respect to the amount of water present. The procedure for conversion of ammonium lactate to lactic acid was facilitated by dilution of the lactate concentrate with ethanol to produce a low-viscosity lactate feed solution for the exchange process as well as an insoluble fraction containing the unfermented carbohydrates and proteins and only 3\% of the lactate. The exchange process proceeded to give a lactic acid solution suitable for feed to the esterification tower; however, the loss of lactate on the column was $17 \%$. Esterification gave lower yields of ester, owing to the lowered lactic acid content of the feed. The lactate was recovered from the exchange column by water washing, and this could be reconcentrated. The use of 95\% ethanol for the dilution/reaction gave significantly lower yields. Removal of water from the $95 \%$ ethanol-diluted feed was investigated. Molecular sieve treatment of the feed removed enough of the water to raise the yields considerably, but further work is needed to study lowering the loss on the exchange column and increasing the lactic acid concentration. Methanol (100\%) will also be investigated to overcome the excess water problem. Other future work will investigate additional solid acid catalysts, such as sulfated zirconia and zeolites, in the flow-through reactor. Catalyst turnover and recovery will be evaluated for the most effective catalysts. Alternative methods for conversion of the ammonium salt will be attempted. Methods for regeneration of the ion exchanger as well as the reactor bed will be investigated. 
In Subtask 3.2, several batch fermentation experiments were conducted using four different microorganisms or strains: Lactobacillus delbruekii, Lactobacillus casei, and two strains of Escherichia coli or E. coli. Fermentation trials were conducted using various media. The feedstock for most of the fermentations was a corn hydrolysate collected from a commercial ethanol production plant owned by Archer Daniels Midland. This raw hydrolysate contained about $300 \mathrm{~g} / \mathrm{L}$ glucose, and nutrients used for the fermentation consisted of Soytone ${ }^{\circledR}$ peptone (Difco) and yeast extract (Difco). All fermentation trials of test bacterial strains and evaporation/concentration trials have been completed. Continued work will include final data analysis and preparation and submission of a final report.

Task 4.0 work is related to project management and strategic studies. The EERC Biomass Utilization - Year 2 project completed a fifth quarter of research and development under nine technical subtask project areas. All projects are completed. 


\section{YEAR 2 BIOMASS UTILIZATION}

\section{INTRODUCTION}

The term "biomass" refers to any organic matter available on a renewable or recurring basis (excluding old-growth timber), including dedicated energy crops and trees, food and feed crop residues, aquatic plants, wood and wood residues, animal wastes, and other waste materials. With concerns over air pollution, greenhouse gas emissions, and dwindling fossil fuels, biomass has emerged as one factor in an intricate equation for a sustainable energy and value-added product future. Inherent in most biomass is a chemistry free from common fossil fuel pollutants such as sulfur and concentrated toxic trace elements. Biomass is derived from living organisms that use or uptake $\mathrm{CO}_{2}$ and is considered $\mathrm{CO}_{2}$ neutral. During plant or animal growth cycles, $\mathrm{CO}_{2}$ comes out of the atmosphere and is taken up by living organisms that comprise biomass. Upon combustion, gasification, fermentation, or some other utilization, the $\mathrm{CO}_{2}$ returns to the atmosphere. Thus $\mathrm{CO}_{2}$ is recycled and not accumulated in the atmosphere.

Biomass is a resource or "feedstock" that can be utilized for three derivative renewable products: bioenergy, transportation biofuels, and other value-added bioproducts. The term "biobased product" usually means a commercial or industrial product (other than food or feed) that utilizes biological products or renewable domestic agricultural (plant, animal, and marine) or forestry materials. Transportation biofuels include such products as biodiesel, made from processing vegetable or other organic seed or animal oils, and ethanol, made from the conversion of plant sugars to alcohol. The term "bioenergy" means biomass used in the production of energy (electricity; liquid, solid, and gaseous fuels; and heat).

In 2001, President Bush unveiled his energy policy and plan for the nation from a biomass-powered district energy plant in St. Paul, Minnesota. In his speech, President Bush cited near- and longer-term energy solutions to a rapidly expanding demand for clean electricity and transportation fuels in the United States. Key to his energy equation is expanding and diversifying America's supply of all sources of energy, including renewables such as biomass. Development of renewable sources of energy, harnessing biomass for power, and providing research and incentives to increase the use of alternative fuels like ethanol were promoted in Bush's energy policy. The U.S. Department of Energy (DOE) followed the President's lead to enhance the utilization of biomass as a renewable energy fuel and went further to promote biomass as a chemical feedstock for marketable value-added bioproducts. The Office of Energy Efficiency and Renewable Energy (EERE), within DOE, underwent an extensive reorganization to refocus research and development into several specific areas, including what was called the Biomass Program. The Biomass Program was developed with two primary platforms of direction in biomass utilization: a sugar platform and a syngas platform. The sugar platform is focused primarily on the hydrolysis of cellulose and hemicellulose to sugars for the production of ethanol; however, this approach was also meant to enable biorefinery technologies for production of many other value-added products. The syngas platform involves developing biomass-derived fuels such as ethanol and other products such as biodegradable solvents using catalytic gasification of raw biomass. 
In fiscal year 2001, DOE entered into a Cooperative Agreement with the Energy \& Environmental Research Center (EERC) at the University of North Dakota to initiate \$1,000,000 worth of new research projects on energy from biomass in a project called EERC Biomass Utilization. A second year of research was promulgated for fiscal year 2002 for this same EERC Biomass Utilization Program under DOE Contract No. DE-FC26-01NT41129. This document is the final technical report for project activities under this current second-year contract. In this report, experimental results, discussion, and conclusions are documented for each of the separate project activities which include the following:

- Biomass Conversion for Heat and Power

- Controlled Spontaneous Reactor for Improving Biomass Feeding for Combustion and Gasification

- Biological Hydrogen Production

- Development of Management Options for Biomass Combustion By-Products

- Ethanol Processing for Fuel Cells

- The Use of Regionally Available Waste Oils and an Improved Catalyst in the Preparation of Biodiesel Fuel

- Assessment of the Use of Ethanol Fuels in Two-Cycle Engines

- Bench-Scale Demonstration of Esterification Biorefinery Routes to Fuel, Solvent, and Chemical Intermediates

- Lactic Acid Fermentation from Amylose Hydrolysate

- Management and Strategic Studies

The goal of the EERC Biomass Utilization Program is to develop economical, environmentally sound technologies that will promote efficient biopower or bioenergy, transportation biofuels, and bioproducts. Specific objectives for the overall research program are stated as follows:

- Develop management options for biomass combustion by-products.

- Study the formation of particulate and vapor species during cofiring of biomass.

- Modify an existing controlled spontaneous reactor (CSR) to effectively process high-moisture cellulosic biomass for conventional and advanced fuel conversion systems. 
- Produce hydrogen suitable for a fuel cell using thermophilic anaerobes for the fermentation of cellulosic biomass.

- Investigate ethanol as a premium fuel for fuel cell applications.

- Formulate novel catalysts for the esterification of waste vegetable oils to biodiesel.

- Design ethanol-blended fuel engine modifications for two-cycle applications.

- Develop new catalysts for the conversion of ethanol and methanol to higher alcohols.

- Study the conversion of corn or other unrefined sugar to ethyl esters such as lactate, propionate, butyrate, or succinate in an ester biorefinery.

- Evaluate the feasibility for acid-catalyzed thermal reactions of lignocellulosics to form ethyl levulinate and succinic acid.

- Examine the use of ammonium hydroxide to facilitate direct conversion of carboxlic acids to esters.

- Perform strategic studies in biomass utilization, including the viability of collocating biomass-to-ethanol plants near utility generating stations, characterizing biomass types for practical uses, and developing technologies in biomass gasification.

The remainder of this report describes experimental procedures, data and results, and conclusions for each of the individual project subtasks.

\section{SUBTASK 1.1 - BIOMASS CONVERSION FOR HEAT AND POWER}

\section{Introduction}

Under the High-Performance Power System Program, DOE funded the development of a pilot-scale slagging furnace system (SFS) at the EERC to test a very high-temperature heat exchanger (HTHX) that would be an integral part of a next-generation solid fuel power system using an indirectly fired combined cycle (IFCC). The novel power system was designed by United Technologies Research Center (UTRC) and the EERC to be at least one-third more efficient while emitting less $\mathrm{SO}_{\mathrm{x}}$ and $\mathrm{NO}_{\mathrm{x}}$ or particulate than current power plants. The technology has applications for both industrial- and large utility-sized plants. The heart of the system is a slagging pulverized coal-fired combustor that uses an HTHX to produce clean air at up to $1800^{\circ} \mathrm{F}\left(982^{\circ} \mathrm{C}\right)$ and $250 \mathrm{psi}$ to turn an aeroderivative turbine, followed by a steam generator and steam turbine. In order to produce clean air at such a high temperature, advanced oxide dispersion-strengthened (ODS) alloys were used for the construction of the HTHX. Thermodynamic calculations indicate system efficiencies of up to $47 \%$ while firing coal and $55 \%$ when using a gas-topping burner for a system employing this technology. The pilot-scale testing 
demonstrated over $2000 \mathrm{hr}$ of operation for the HTHX, including a short test producing air at $2000^{\circ} \mathrm{F}\left(1093^{\circ} \mathrm{C}\right)$, without observable creep, deformation, or significant corrosion.

Even though the tests indicate that an IFCC plant will have much higher efficiencies than today's plants, emissions of $\mathrm{CO}_{2}$ and Resource Conservation and Recovery Act pollutants can be reduced even more by cofiring coal with an opportunity biomass fuel. Therefore, the EERC requested and was granted funds from the Xcel Energy Renewable Development Fund, with matching funds from the DOE National Energy Technology Laboratory-funded EERC Biomass Utilization Program, with the objective of demonstrating the practicality of burning coal and biomass blends in a simulated IFCC system. Secondary objectives are to determine through laboratory-scale testing the approximate lifetimes of candidate ODS alloys that could be used to construct an HTHX and to refine methods of joining these advanced alloys since standard welding techniques will not work with ODS materials.

The main focus of the pilot-scale testing is to evaluate system operations; mechanisms of air pollutant formation including fine particulate, $\mathrm{SO}_{\mathrm{x}}$, and $\mathrm{NO}_{\mathrm{x}}$; operational issues related to ash fouling and slagging; and slag corrosion of ODS alloy heat exchanger and refractory materials. With the performance of three tests during the last quarter of 2003, the pilot-scale work for the program was completed. A description of the results of those tests is presented in this report. Three different biomass-coal blends were fired. The biomass types were wood-processing residue (hog fuel), raw corn stover, and unprocessed switchgrass. The coal was from the Powder River Basin (PRB) of Wyoming. The tests of slag corrosion of cooled heat exchanger alloys are being done in a laboratory-scale slagging furnace to determine approximate alloy lifetimes and whether or not converting biomass-coal blends in an advanced power system presents any special corrosion or slag flow problems in the operation of that system. In addition, new methods of joining the ODS alloys are being developed and tested. The methods include transient liquidphase bonding in which a thin layer of a reactive metal is used to join pieces together and the development of machining and pretreatment methods for preparing threads in these gall-prone alloys.

\section{Materials Testing}

\section{Corrosion}

The EERC laboratory-scale dynamic slag application furnace (DSAF) is being used to measure the corrosion rates of sections of cooled MA956 tube to flowing slag. MA956 is an iron-chrome-aluminum alloy containing approximately $0.5 \%$ yttria particles dispersed throughout the material to reduce creep of the grain boundaries at high temperatures. It is the same material that was used to replace the center tube of the HTHX as reported previously. Figure 1 shows a schematic of the DSAF system. During testing, the furnace is heated to $1500^{\circ} \mathrm{C}$ while the surface of the alloy tube section is cooled to $1050^{\circ} \mathrm{C}$ by internal airflow. The slag is screw-fed into the furnace system as sandlike grains where it drops into a platinum pan. After melting in the pan, the slag drips onto the surface of the cooled alloy tube section at approximately the 11 o'clock position. It is administered at a rate equal to the maximum 


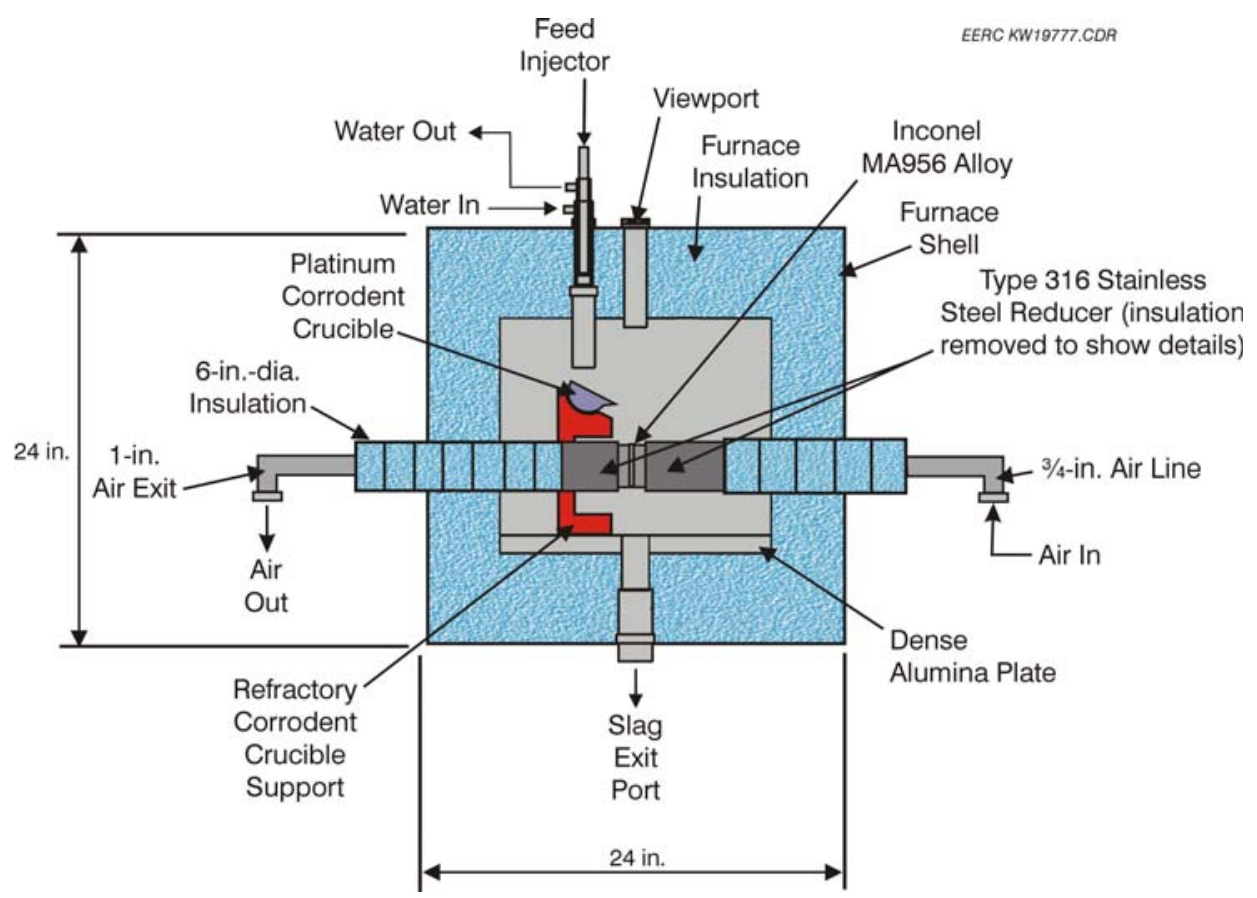

Figure 1. The EERC DSAF system.

expected in the pilot-scale system $(10 \mathrm{~g} / \mathrm{hr}$ ). It then flows around the cooled tube and drips off the alloy and out of the furnace through a hole in its bottom. After $100 \mathrm{hr}$ of slag exposure, the DSAF is cooled, the alloy tube is removed and photographed, and its diameter is measured with a caliper. The surface is then sprayed with dilute epoxy to hold the remaining slag in place, and the tube section is cut into pieces, then embedded in epoxy, cross-sectioned, and polished for analysis in a scanning electron microscope (SEM).

The DSAF testing provides a worst-case scenario corrosion test for the alloys because the corrosion mechanism is more severe than would be encountered by a heat exchanger in a power system. It is more severe because the slag is dripped directly onto the surface of the alloy, whereas in a power system, the surface is coated with a thin layer of less reactive sintered fly ash before building to the thickness at which the slag becomes molten. For this quarter, three separate 100-hr tests were performed, one each for the three SFS slags formed during testing of each of the coal-biomass blends. Table 1 shows the slag analyses. Figure 2 shows the surfaces of the alloy tube sections after the second and third tests. Physical and SEM analyses of the corroded materials will be performed over the next quarter.

\section{Joining}

The ODS alloys used to construct the HTHX exhibit extremely high corrosion and creep resistance. These properties are imparted to the alloys because of the dispersion of the yttria particles throughout the alloy structure. However, because they must remain dispersed, the alloys 
Table 1. Slag Analyses

\begin{tabular}{lccc}
\hline Oxides, ${ }^{a}$ wt $\%$ & $\begin{array}{c}\text { 80\% North Antelope } \\
\text { 20\% Hog Fuel }\end{array}$ & $\begin{array}{c}\text { 80\% North Antelope } \\
\text { 20\% Corn Stover }\end{array}$ & $\begin{array}{c}\text { 80\% North Antelope } \\
\text { 20\% Switchgrass }\end{array}$ \\
\hline $\mathrm{SiO}_{2}$ & 37.7 & 45.5 & 51 \\
$\mathrm{Al}_{2} \mathrm{O}_{3}$ & 20.1 & 18.6 & 15.2 \\
$\mathrm{Fe}_{2} \mathrm{O}_{3}$ & 5.4 & 5.3 & 5.4 \\
$\mathrm{TiO}_{2}$ & 1.1 & 1.1 & 1 \\
$\mathrm{P}_{2} \mathrm{O}_{5}$ & 0.9 & 1 & 1.1 \\
$\mathrm{CaO}$ & 28 & 20.3 & 18.9 \\
$\mathrm{MgO}$ & 4.4 & 5.9 & 5 \\
$\mathrm{Na}_{2} \mathrm{O}$ & 1.2 & 0.9 & 0.8 \\
$\mathrm{~K}_{2} \mathrm{O}$ & 1.1 & 1.4 & 1.5 \\
$\mathrm{SO}_{3}{ }^{\mathrm{b}}$ & 0 & 0 & 0 \\
\hline
\end{tabular}

${ }^{\mathrm{a}}$ Fuel and slag oxide concentrations normalized to an $\mathrm{SO}_{3}$-free basis.

b Fuel and slag $\mathrm{SO}_{3}$ concentrations normalized with other oxides.

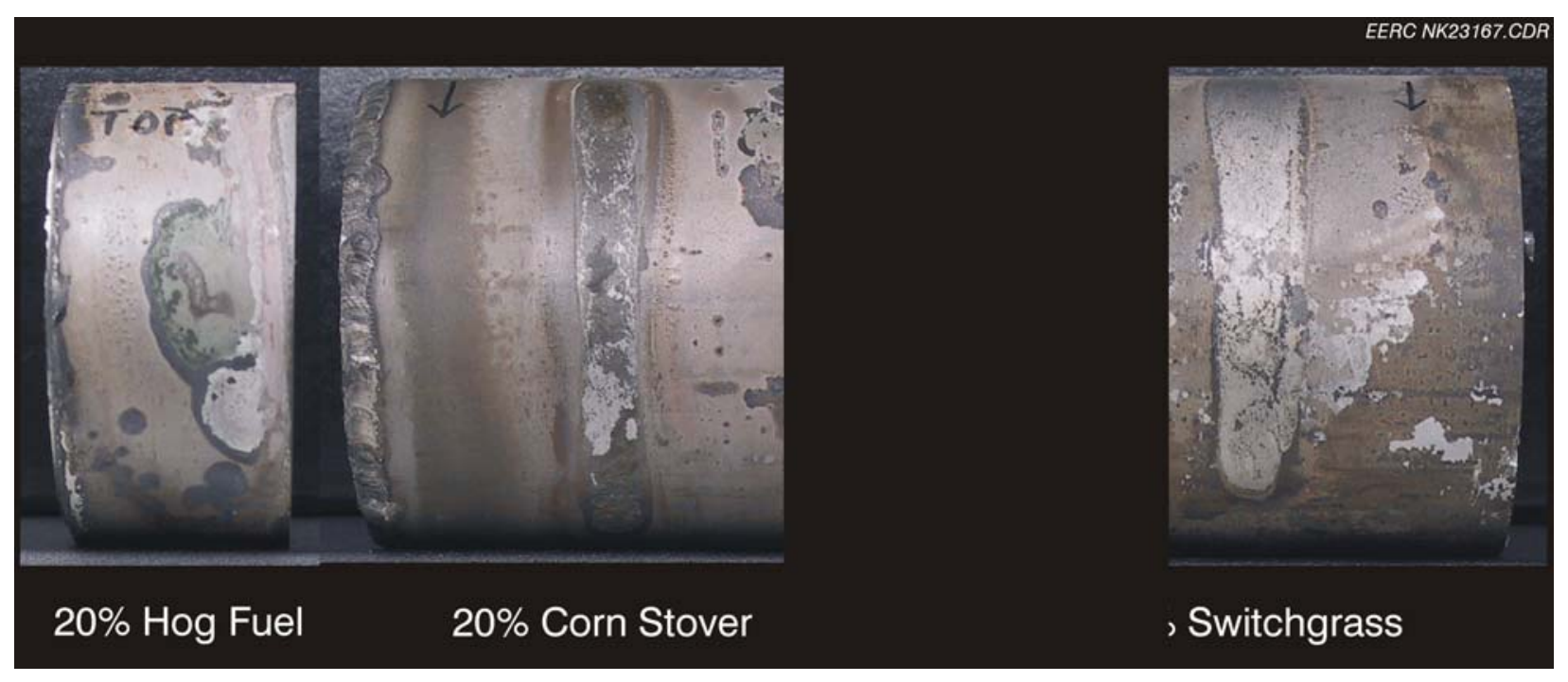

Figure 2. The surfaces of the MA956 tube sections after flowing slag corrosion testing in the DSAF. 
cannot be welded because melting would allow the oxides to segregate in the joint, diminishing the usefulness of the metal. Therefore, the EERC is working with Oak Ridge National Laboratory (ORNL) to develop a method for joining the MA956 using transient liquid-phase (TLP) bonding. In the TLP method, a thin foil of a proprietary alloy is placed between the pieces to be joined, and the joint is heated, causing interdiffusion of the ODS and foil materials at temperatures well below the melting point of the ODS metal. If the oxides stay well dispersed within the joint, then the joint should maintain a high fraction of the maximum usable temperature of the ODS material.

During this quarter, one TLP metal foil type provided by ORNL was used to join pieces of MA956 under three different processing conditions. Both the TLP metal type and processing conditions remain proprietary and so cannot be described, but the three conditions will be labeled as A, B, and C for the purposes of this report. The three TLP-bonded samples were cross-sectioned and examined by SEM.

An SEM micrograph of Joint A is shown in Figure 3. The TLP metal migrated approximately $150 \mu \mathrm{m}$ into the ODS alloy, but left relatively large areas of highly concentrated TLP metal within the ODS alloy. Minor porosity was detected at the joint interface. A yttrium/aluminum-rich particle phase was formed at the interface, with a concentration of $45 / 25 \mathrm{wt} \%$, respectively, that contained small amounts of chromium and iron. Oxygen content was very low and, in many instances, not detected, so the particles are not oxides. The particle diameter was approximately $4 \mu \mathrm{m}$. The yttrium/aluminum particles were also detected away from the interface but always adjacent to an area of TLP metal. This relationship is not fully understood and is being researched. The large TLP metal concentrations were centered at about

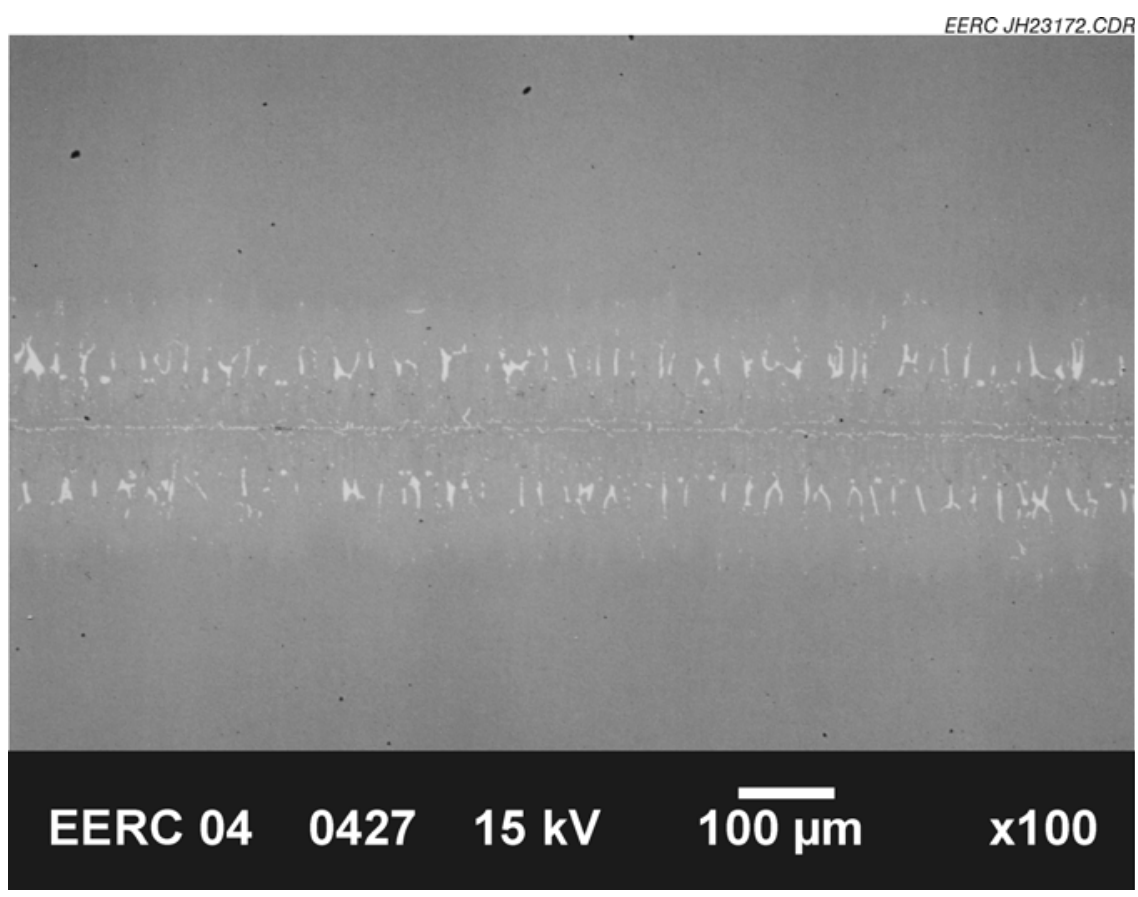

Figure 3. SEM micrograph of Joint A. The light area is the TLP metal diffusion. 
$70 \mu \mathrm{m}$ from the interface. It is difficult to tell during SEM examination, but the metal appears to be traveling between ODS alloy grains. The metal contains elevated levels of aluminum and titanium, with small amounts of iron and chromium. The titanium concentration was triple that of the base alloy. As that implies, the surrounding alloy was slightly deficient in aluminum and titanium.

TLP Joint B is shown in Figure 4. Porosity at the interface is minor. Migration of TLP metal from the interface was detected to a distance of approximately $350 \mu \mathrm{m}$, or roughly twice that of Joint A. Concentrations of TLP metal can still be observed; however, they are smaller, thinner, and at the outer limits of the metal migration. The TLP metal concentration at the joint interface is much less than that found in Joint A. The same yttrium/aluminum-rich phase was observed adjacent to areas rich in TLP metal as before. The particle size of this phase was about half that of the previous sample. A new TLP metal phase was detected which has titanium levels eight times that of the base alloy. The phase appears as small, $2 \mu \mathrm{m}$ and less, particles dispersed in the TLP-affected zone of the alloy. This is a curious, unexpected phase that is also being investigated.

Joint $C$ is shown in Figure 5. Migration of the TLP metal is approximately the same as that of Joint $\mathrm{B}$, but the dispersion is even greater. The porosity at the interface was low, but higher than that of the two previous joints. The yttrium/aluminum-rich phase was still present, but the particle size was found to be approximately $1-2 \mu \mathrm{m}$. The titanium-rich phase was found in the sample, with titanium concentrations now reaching $75 \mathrm{wt} \%$, but the particle size is roughly the same as for Joint B. The TLP metal-rich areas of this sample have iron and titanium concentrations which are roughly double that of Joint B.

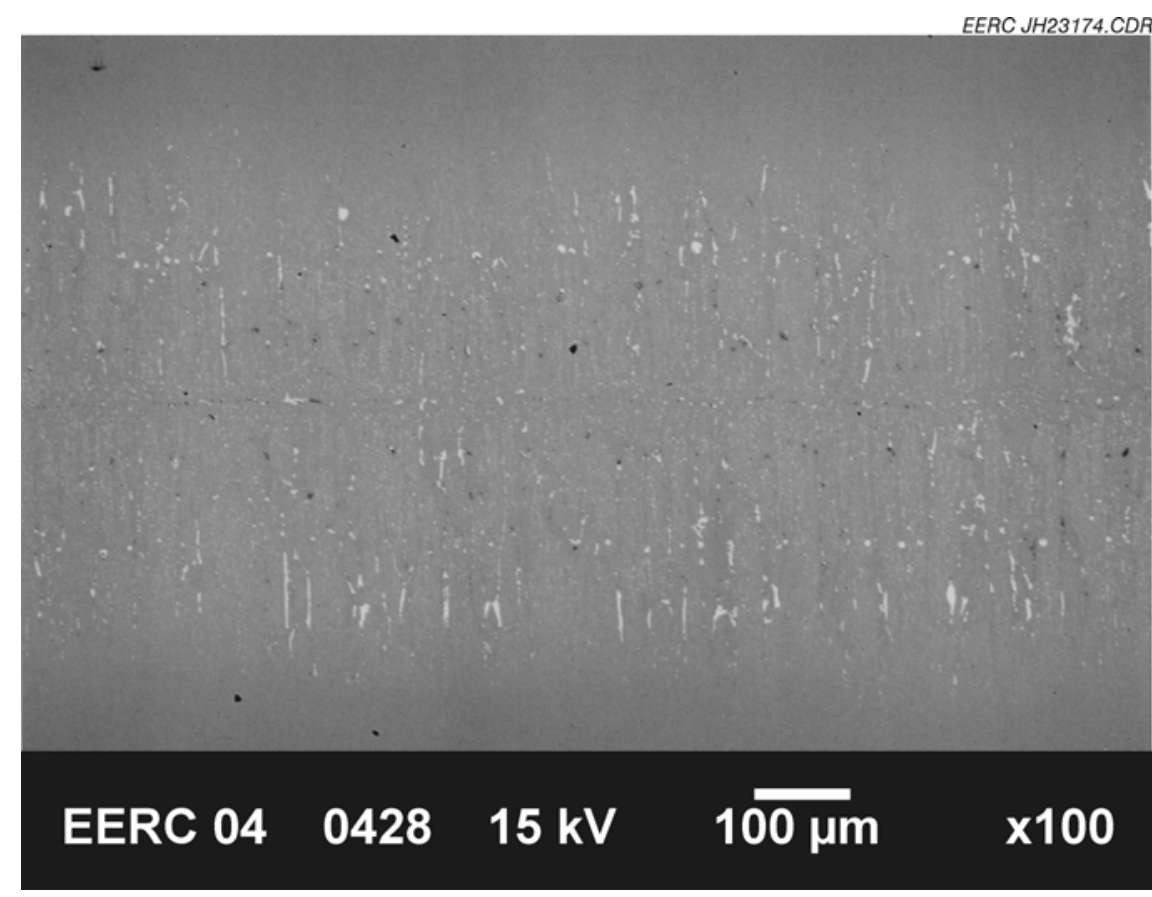

Figure 4. SEM micrograph of Joint B. 


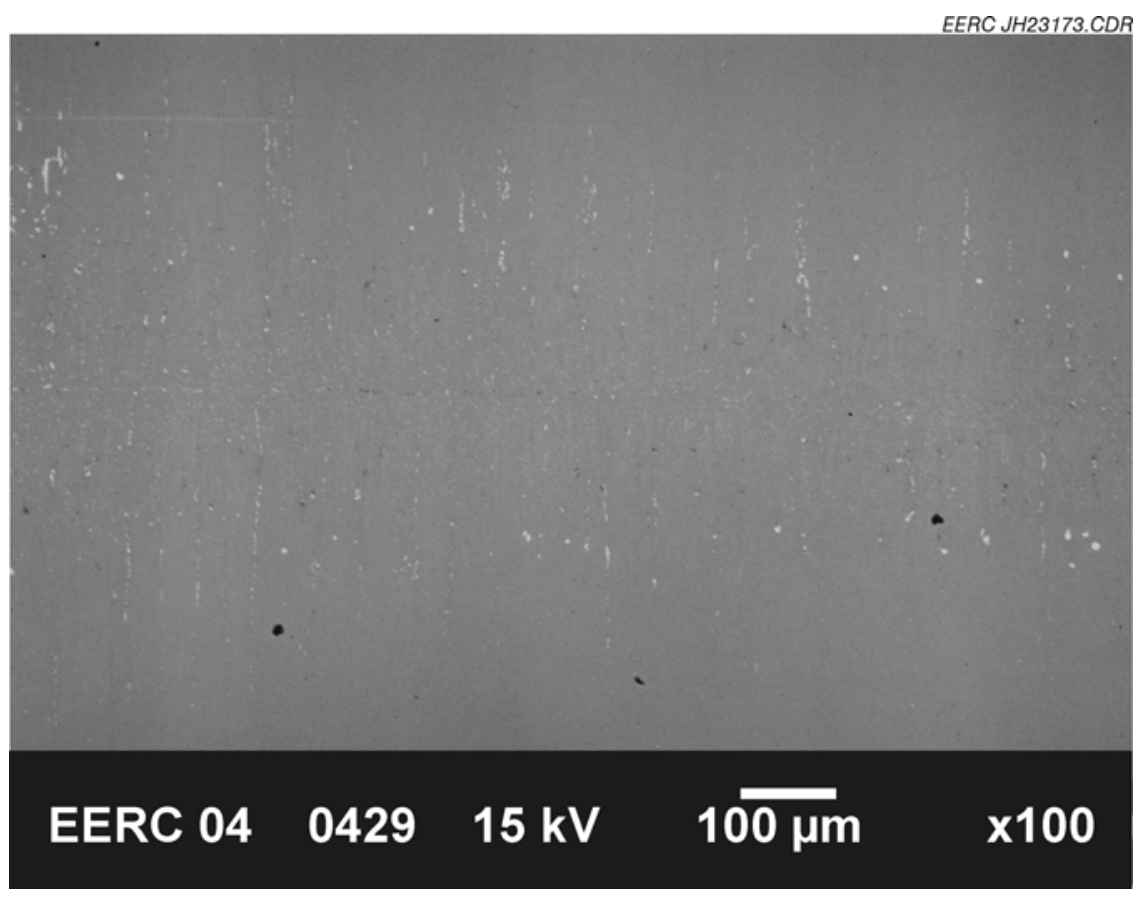

Figure 5. SEM micrograph of Joint C.

A summary of the SEM results is shown in Table 2. TLP metal migration and dispersion improved with joining temperature. At the higher temperatures, an unexpected secondary titanium-enriched phase was formed and is being investigated. Porosity was very low but increased slightly with temperature. Residual TLP metal in the joint was enriched in aluminum, titanium, iron, and a little chromium. This proved to be the opposite of what was expected. It was believed that the metal would disperse into the iron, but it appears that the iron is actually dispersing into the TLP metal. This is also being further investigated. The migration of the metal appears to be between the grain boundaries. Overall, these TLP results appear very promising, but ultimately it is the strength of the joints that is of utmost importance. Therefore, portions of each of the joints have been sent to ORNL for tensile strength testing.

\section{Pilot-Scale Cofiring Tests}

The three pilot-scale coal-biomass cofiring tests were completed the weeks of October 9-17 (XCEL1), November 14-21 (XCEL2), and December 12-19 (XCEL3), 2003. Each test involved cofiring biomass with North Antelope subbituminous coal at a nominal firing rate basis of $80 \%$ coal and $20 \%$ biomass. The three biomass fuel types were selected based on discussions with the Xcel technical advisor for the project. They included a hog fuel consisting of wood waste from a lumber-processing mill which is currently being burned in small quantities at an Xcel plant and two agricultural fuel sources: corn stover and switchgrass. Coal and biomass fuels were blended, using two loss-in-weight gravimetric feeders, into the primary air line supporting the operation of a single burner. Only $39 \%$ of the HTHX alloy surface was exposed to furnace 
Table 2. Summary of SEM Examinations of the TLP Joints

\begin{tabular}{|c|c|c|c|c|c|c|}
\hline & $\begin{array}{l}\text { TLP Metal } \\
\text { Migration }\end{array}$ & $\begin{array}{c}\text { Metal } \\
\text { Dispersion }\end{array}$ & $\begin{array}{l}\text { Residual } \\
\text { Metal }\end{array}$ & Porosity & Y/Al Phase & Metal/Ti Phase \\
\hline A & $150 \mu \mathrm{m}$ & Poor & $\begin{array}{c}\text { Thick - } \\
\text { concentrated } \\
\text { near } \\
\text { midpoint of } \\
\text { dispersion }\end{array}$ & Minor & Present & $\begin{array}{c}\text { Not } \\
\text { present }\end{array}$ \\
\hline B & $300 \mu \mathrm{m}$ & Better & $\begin{array}{l}\text { Thin - } \\
\text { concentrated } \\
\text { at edge of } \\
\text { dispersion }\end{array}$ & Minor & $\begin{array}{c}\text { Present } \leq 2 \mu \mathrm{m} \\
\text { particle size }\end{array}$ & $\begin{array}{c}\text { Present } \leq 2 \mu \mathrm{m} \\
\text { particle size }\end{array}$ \\
\hline $\mathrm{C}$ & $300 \mu \mathrm{m}$ & Best & $\begin{array}{l}\text { Very thin - } \\
\text { concentrated } \\
\text { at edge of } \\
\text { dispersion }\end{array}$ & $\begin{array}{l}\text { Minor, } \\
\text { but } \\
\text { higher } \\
\text { than the } \\
\text { others }\end{array}$ & $\begin{array}{c}\text { Present } \leq 2 \mu \mathrm{m} \\
\text { particle size }\end{array}$ & $\begin{array}{l}\text { Present } \leq 2 \mu \mathrm{m} \\
\text { particle size, } \\
\text { much higher } \mathrm{Ti} \\
\text { content }\end{array}$ \\
\hline
\end{tabular}

conditions during the biomass-cofiring tests because of limitations on process air available to support the HTHX and to avoid overheating the alloy surface. Based on ash characterization, alloy tube surface temperature was limited to $<1925^{\circ} \mathrm{F}\left(<1052^{\circ} \mathrm{C}\right)$ to freeze an ash layer on the surface of the tubes and minimize the potential for slag corrosion/erosion of the alloy.

Specific pilot-scale combustion test objectives included 1) coal-biomass cofiring for a period of $85 \mathrm{hr}$ to establish an ash-slag layer on the HTHX alloy tubes and obtain steady-state heat-transfer data; 2) evaluating the impact of biomass cofiring on convective air heater (CAH) performance as well as other SFS components; 3) determining flue gas particulate mass loading and particle size at the baghouse inlet and baghouse particulate collection efficiency; 4) evaluating baghouse differential pressure control; and 5) documenting flue gas composition for $\mathrm{SO}_{2}, \mathrm{NO}_{\mathrm{x}}, \mathrm{CO}_{2}, \mathrm{CO}$, and $\mathrm{O}_{2}$.

During this past quarter, the focus of activities related to the pilot-scale tests was evaluation of the data and summarizing results. Summarized results are presented in this final report concerning fuel characteristics and select SFS performance issues. In addition, CAH and HTHX heat-transfer data and observations are summarized. Conclusions based on the data are presented as well as recommendations for further work where warranted.

\section{Fuel Characteristics}

North Antelope subbituminous coal was selected for use during this project because it is currently used by Xcel Energy for power production at the Sherburne County Station. Biomass fuel selections included hog fuel, corn stover, and switchgrass. Hog fuel was selected because wood residues are the most widely available biomass fuels, and hog fuel is currently fired at 
Xcel's Ashland, Wisconsin, plant. Hog fuel consists of bark and wood remnants from the processing of trees. While sawdust is much more desirable because of its handling characteristics and typically small inorganic content, hog fuel is more abundant and cheaper because it has a higher inorganic content and requires further processing to feed into a combustion system. Corn stover, an agricultural by-product, was selected because of its availability in the upper Midwest, and switchgrass was selected because it has been identified as a potential energy crop in a number of technical and economic biomass energy studies. Table 3 summarizes fuel and fuel ash data for the coal-biomass cofiring tests.

\section{Slagging Furnace Operation}

The slagging furnace heatup rate in support of this project was limited to $100^{\circ} \mathrm{F} / \mathrm{hr}$ $\left(56^{\circ} \mathrm{C} / \mathrm{hr}\right)$ while natural gas was fired. This is the heatup rate recommended by the manufacturer for the high-density castable refractory forming the inner surface of the furnace. Based on ash characterization, alloy tube surface temperature was limited to $<1925^{\circ} \mathrm{F}\left(<1052^{\circ} \mathrm{C}\right.$ ) when coal and biomass were cofired to minimize the potential for slag corrosion/erosion of the alloy tube surfaces. Therefore, furnace firing rates and resulting furnace temperatures were adjusted to control alloy tube surface temperatures in the range of $1900^{\circ}-1920^{\circ} \mathrm{F}\left(1038^{\circ}-1049^{\circ} \mathrm{C}\right)$ for nominal process air flow rates of $390 \mathrm{scfm}\left(11.0 \mathrm{~m}^{3} / \mathrm{min}\right)$. Once this temperature range was achieved, natural gas firing was continued for at least $4 \mathrm{hr}$ so that furnace refractory was approaching thermal equilibrium. Subsequently, the main burner was switched from natural gas to coal-biomass cofiring, and feed rate adjustments were made to maintain alloy tube surface temperatures in the range of $1900^{\circ}-1920^{\circ} \mathrm{F}\left(1038^{\circ}-1049^{\circ} \mathrm{C}\right)$. After $12 \mathrm{hr}$ of solid fuel firing and once the furnace had reached thermal equilibrium, most fuel feed adjustments were limited to the coal as it represented nominally $80 \%$ of the heat input. Figure 6 is an illustration of the SFS updated to include the biomass feed system installed to support this project.

The primary objective of the coal-biomass cofiring tests was to evaluate the performance of the HTHX while North Antelope subbituminous coal and the hog fuel, corn stover, and switchgrass were cofired individually during an 85-hr test period. The North Antelope subbituminous coal feed was continuous for a minimum of $85 \mathrm{hr}$ during the biomass-cofiring tests. Biomass feed was continuous for the corn stover and switchgrass cofiring tests. However, after 2 hr of coal-hog fuel cofiring, an electrical switch box supporting the biomass feeder failed, forcing an increase in the coal feed rate to maintain furnace temperatures. The electrical switch box was replaced over a 2-hr period, and coal-hog fuel cofiring resumed and continued uninterrupted for the balance of the test period.

Excluding the 2-hr biomass feed interruption during the coal-hog fuel test, the coal feed rate ranged from 166 to $185 \mathrm{lb} / \mathrm{hr}$ (75 to $84 \mathrm{~kg} / \mathrm{hr}$ ). However, once the furnace reached thermal stability, the feed rate was typically $170-180 \mathrm{lb} / \mathrm{hr}(77-82 \mathrm{~kg} / \mathrm{hr})$. Minor adjustments to the coal feed rate were made occasionally to maintain the HTHX alloy surface temperature in the desired range. The biomass feed rates were nominally $60-70 \mathrm{lb} / \mathrm{hr}(27-32 \mathrm{~kg} / \mathrm{hr})$. Generally, both the coal and biomass feed rates were stable. However, during the final $24 \mathrm{hr}$ of coal-hog fuel 
Table 3. Results of Fuel and Fuel Ash Analysis for the Coal-Biomass Cofiring Tests ${ }^{1}$

\begin{tabular}{|c|c|c|c|c|}
\hline Analyses & $\begin{array}{c}\text { North Antelope } \\
\text { Subbituminous Coal }^{2}\end{array}$ & Hog Fuel & Corn Stover & Switchgrass \\
\hline \multicolumn{5}{|l|}{ Proximate Analysis, wt\% } \\
\hline Moisture & $21.1-22.8$ & 12.2 & 7.7 & 6.9 \\
\hline Volatile Matter & $36.3-37.2$ & 69.4 & 74.5 & 74.1 \\
\hline Fixed Carbon & $37.2-37.9$ & 13.4 & 10.6 & 13.6 \\
\hline Ash & $3.7-3.9$ & 5 & 7.1 & 5.4 \\
\hline \multicolumn{5}{|l|}{ Ultimate Analysis, wt\% } \\
\hline Hydrogen & $6.0-6.1$ & 6.2 & 6.1 & 6 \\
\hline Carbon & $53.1-54.5$ & 39.3 & 42.2 & 42.4 \\
\hline Nitrogen & $0.9-1.0$ & 0.5 & 0.8 & 1.2 \\
\hline Sulfur & $0.23-0.25$ & 0.04 & 0.12 & 0.13 \\
\hline Oxygen & $34.6-36.1$ & 49 & 43.6 & 44.9 \\
\hline Ash & $3.7-3.9$ & 5 & 7.1 & 5.4 \\
\hline Heating Value, Btu/lb & 9306-9458 & 8036 & 7715 & 7402 \\
\hline \multicolumn{5}{|l|}{ Percent as Oxides, wt\% } \\
\hline $\mathrm{SiO}_{2}$ & 25.9-27.2 & 33.3 & 57.3 & 70.3 \\
\hline $\mathrm{Al}_{2} \mathrm{O}_{3}$ & $17.0-18.3$ & 2.5 & 3.2 & 0 \\
\hline $\mathrm{Fe}_{2} \mathrm{O}_{3}$ & $7.2-7.6$ & 3.2 & 1.4 & 0.25 \\
\hline $\mathrm{TiO}_{2}$ & 1.5 & 0.3 & 0.3 & 0.03 \\
\hline $\mathrm{P}_{2} \mathrm{O}_{5}$ & 1.2 & 1.8 & 3.8 & 4.8 \\
\hline $\mathrm{CaO}$ & $26.3-26.9$ & 43.2 & 9.5 & 9.4 \\
\hline $\mathrm{MgO}$ & $6.9-7.2$ & 3.9 & 12.6 & 4.9 \\
\hline $\mathrm{Na}_{2} \mathrm{O}$ & $0.8-1.2$ & 3.9 & 0.4 & 0.03 \\
\hline $\mathrm{K}_{2} \mathrm{O}$ & $0.2-0.3$ & 7.9 & 10 & 7 \\
\hline $\mathrm{SO}_{3}$ & $8.9-12.4$ & 0 & 1.5 & 3.3 \\
\hline \multicolumn{5}{|l|}{ Ash Fusion Temp., ${ }^{\circ} \mathrm{F}$} \\
\hline Initial & 2209-2235 & 2461 & 2249 & 2459 \\
\hline Softening & $2213-2244$ & 2507 & 2273 & 2468 \\
\hline Hemisphere & $2225-2251$ & 2583 & 2283 & 2638 \\
\hline Fluid & $2241-2296$ & 2673 & 2350 & 2658 \\
\hline \multicolumn{5}{|l|}{ Sieve Analysis } \\
\hline Screen Mesh Size & & & Weight Percent & \\
\hline Coal 100, Biomass 16 & $6.5-7.2$ & 2.3 & 9.1 & 4.2 \\
\hline Coal 140, Biomass 18 & $10.5-12.3$ & 4 & 2 & 3.4 \\
\hline Coal 200, Biomass 20 & $14.0-14.9$ & 4.6 & 3 & 3.4 \\
\hline Coal 230, Biomass 30 & $7.1-8.7$ & 16.1 & 12.6 & 10.9 \\
\hline Coal 270, Biomass 40 & $1.2-7.2$ & 17.8 & 22.2 & 21 \\
\hline Coal 325, Biomass 60 & 3.9-8.6 & 24.1 & 24.2 & 24.4 \\
\hline Pan & $43.7-49.7$ & 31 & 26.8 & 32.7 \\
\hline Total \% & 100 & 100 & 100 & 100 \\
\hline Bulk Density, lb/ft ${ }^{3}$ & $37.5-40.0$ & 15.5 & 8.5 & 9 \\
\hline
\end{tabular}

${ }^{1}$ Analysis is presented on an as-fired basis.

${ }^{2}$ These data represent the analysis results from composite samples collected during the three coal-biomass cofiring tests.

cofiring, the hog fuel feed rate became erratic, ranging from 50-90 lb/hr (23-41 kg/hr). Inspection of the biomass feeder during maintenance activities following the test determined that some wood debris had found its way into the feeder. Once this debris was removed, a short operational test demonstrated that the feed rate stability previously observed was restored. Momentary spikes in the coal and biomass feed rates were observed during feed hopper refill 


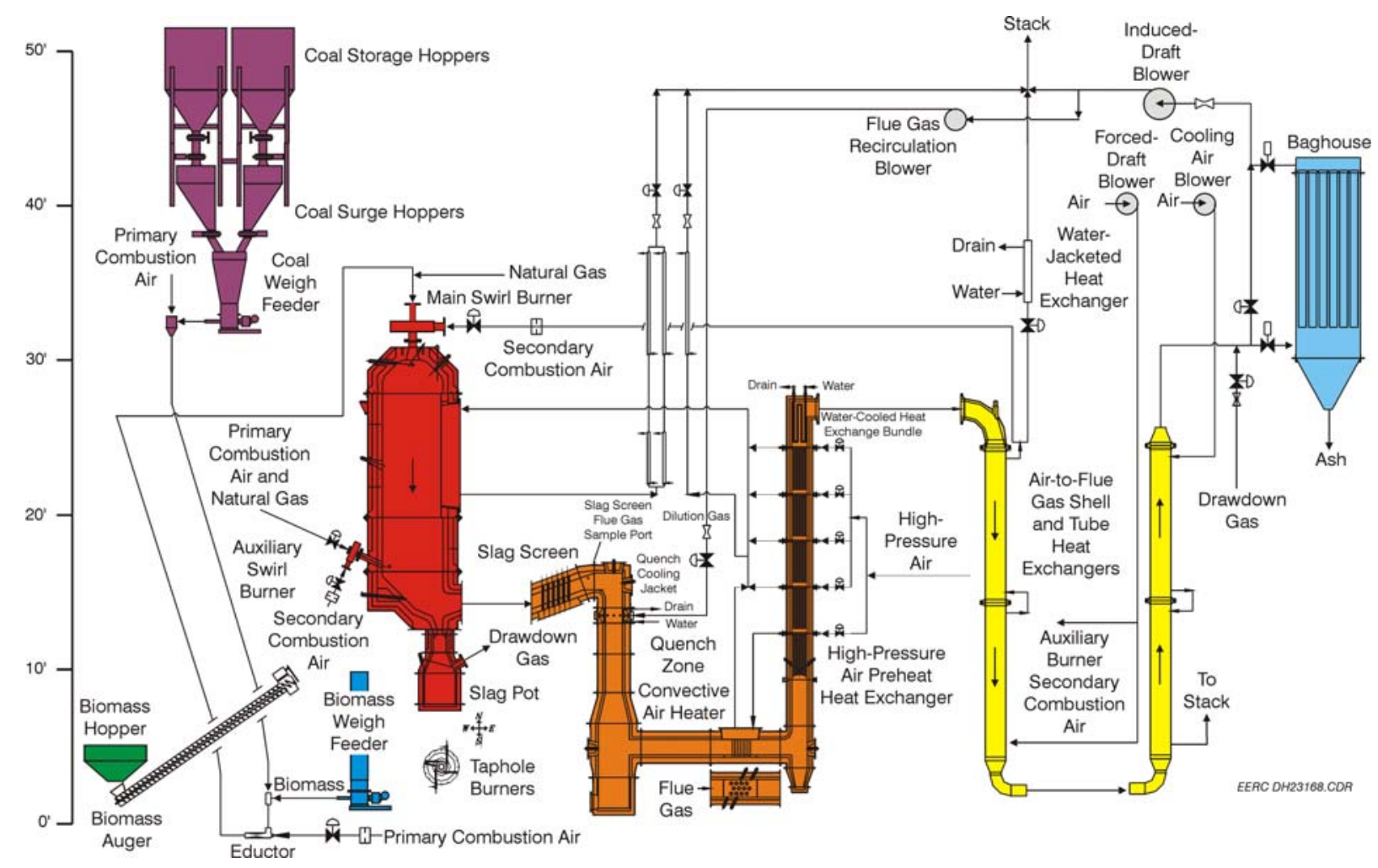

Figure 6. Illustration of the updated SFS.

cycles. The switchgrass feed rate was less stable than the hog fuel or corn stover. The reason for greater switchgrass feed rate instability was not specifically determined. However, it is believed to be related to the cylindrical geometry of the material and the impact the geometry has on mass flow through the feed hopper. It likely tends to bridge more than the other two biomass materials. Also, inspection of the biomass feeder following Test XCEL3 indicated switchgrass packing around the screw within the housing, an observation that was not evident with the hog fuel or corn stover. During future coal-biomass cofiring tests with the SFS, the size of the biomass fuel should be further reduced to determine potential benefits with respect to feed rate stability and general operability of the SFS.

Furnace exit temperatures during the coal-biomass-cofiring test periods ranged from $2570^{\circ}$ to $2720^{\circ} \mathrm{F}\left(1410^{\circ}\right.$ to $\left.1494^{\circ} \mathrm{C}\right)$ as a result of main burner firing rates of $2.0-2.3 \mathrm{MMBtu} / \mathrm{hr}$ $\left(2.1-2.4 \times 10^{6} \mathrm{~kJ} / \mathrm{hr}\right)$. Once the furnace refractory reached thermal equilibrium after nominally $12 \mathrm{hr}$ of solid fuel firing, furnace exit temperatures averaged $2632^{\circ} \mathrm{F}\left(1445^{\circ} \mathrm{C}\right), 2704^{\circ} \mathrm{F}$ $\left(1485^{\circ} \mathrm{C}\right)$, and $2671^{\circ} \mathrm{F}\left(1466^{\circ} \mathrm{C}\right)$, respectively, for Tests XCEL1, XCEL2, and XCEL3. Standard deviations ranged from $11^{\circ}$ to $29^{\circ} \mathrm{F}\left(6^{\circ}\right.$ to $\left.16^{\circ} \mathrm{C}\right)$. Based on fuel feed rate and analysis data, coal firing represented nominally 74\%, 77\%, and 80\%, respectively, for Tests XCEL1, XCEL2, and XCEL3. Biomass firing represented nominally 26\% (hog fuel), 23\% (corn stover), and 20\% (switchgrass) of the heat input through the main burner. Auxiliary burner-firing rates ranged 
from 0.55 to $0.70 \mathrm{MMBtu} / \mathrm{hr}\left(0.58\right.$ to $0.74 \times 10^{6} \mathrm{~kJ} / \mathrm{hr}$ ), resulting in total furnace firing rates of 2.6-3.0 MMBtu/hr (2.7-3.2 × $\left.10^{6} \mathrm{~kJ} / \mathrm{hr}\right)$. The main burner-firing rate represented $76 \%-80 \%$ of the total firing rate during the coal-biomass-fired test periods. Normally, during air-blown operation, the auxiliary burner-firing rate is limited to nominally $0.50 \mathrm{MMBtu} / \mathrm{hr}(0.53 \times$ $10^{6} \mathrm{~kJ} / \mathrm{hr}$ ) representing $<20 \%$ of the total furnace firing rate. However, it was necessary to fire the auxiliary burner at a slightly higher rate to maintain a sufficiently high slag screen temperature to avoid plugging problems in the slag screen. This was necessary because of the relatively low alloy surface temperature limit, $<1925^{\circ} \mathrm{F}\left(<1052^{\circ} \mathrm{C}\right)$, imposed for the HTHX and the higher ash fusion fluid temperatures, nominally $90^{\circ}-420^{\circ} \mathrm{F}\left(50^{\circ}-233^{\circ} \mathrm{C}\right)$ higher, observed for the biomass fuels when compared to the coal.

Furnace exit temperatures for the three coal-biomass-cofired test periods were similar but not identical. One explanation may be the moisture levels in the three biomass fuels. The hog fuel had the highest moisture level of the three biomass fuels and resulted in the lowest average furnace exit temperature, even though in combination with the coal fired, it represented the highest average firing rate. Based on the temperature and firing rate data and fuel characteristics, the differences in the furnace exit temperatures for the corn stover and switchgrass tests were likely a function of firing rate alone. For illustration purposes, fuel feed rate, slagging furnace firing rate, and furnace temperature data are presented as a function of run time in Figures 7, 8, and 9, respectively, for Test XCEL2 cofiring corn stover.

No forced SFS shutdowns or serious operating problems were encountered during any of the three pilot-scale combustion tests. However, hog fuel cofiring was interrupted for $2 \mathrm{hr}$, and the compressor supplying process air to the HTHX tripped twice while cofiring switchgrass.

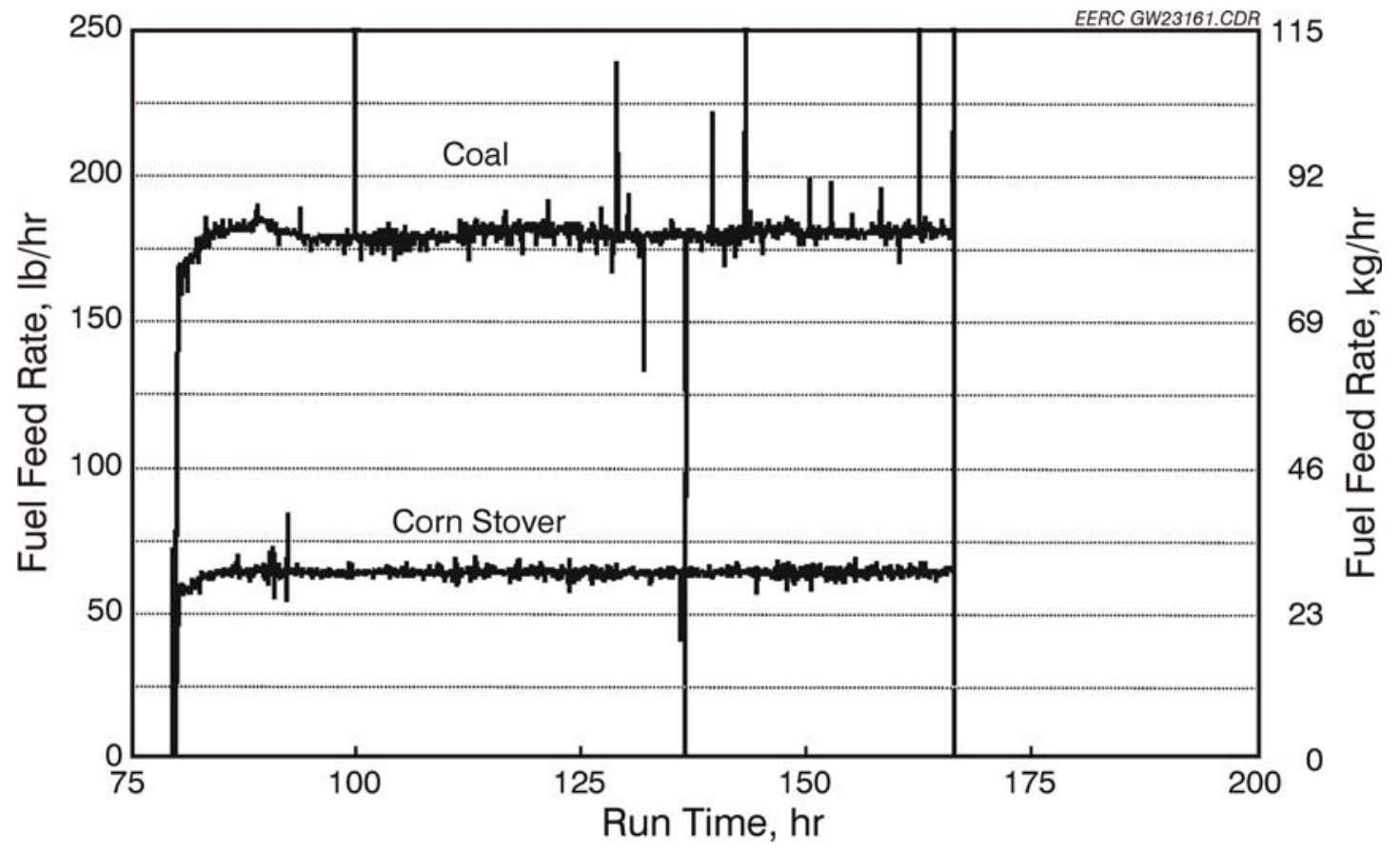

Figure 7. Fuel feed rate versus run time for Test SFS-XCEL2-0403. 


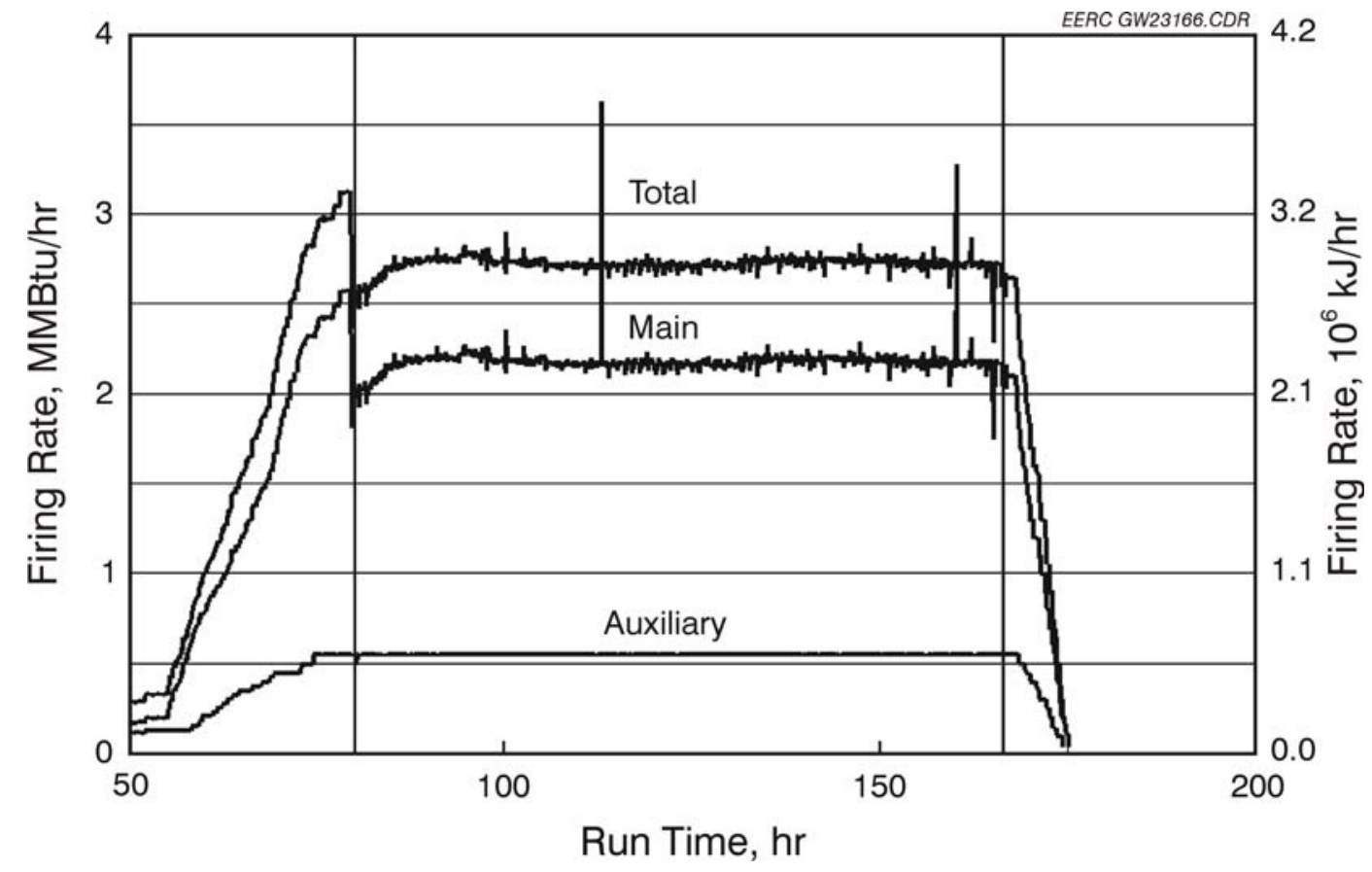

Figure 8. Slagging furnace firing rate versus run time for Test SFS-XCEL2-0403.

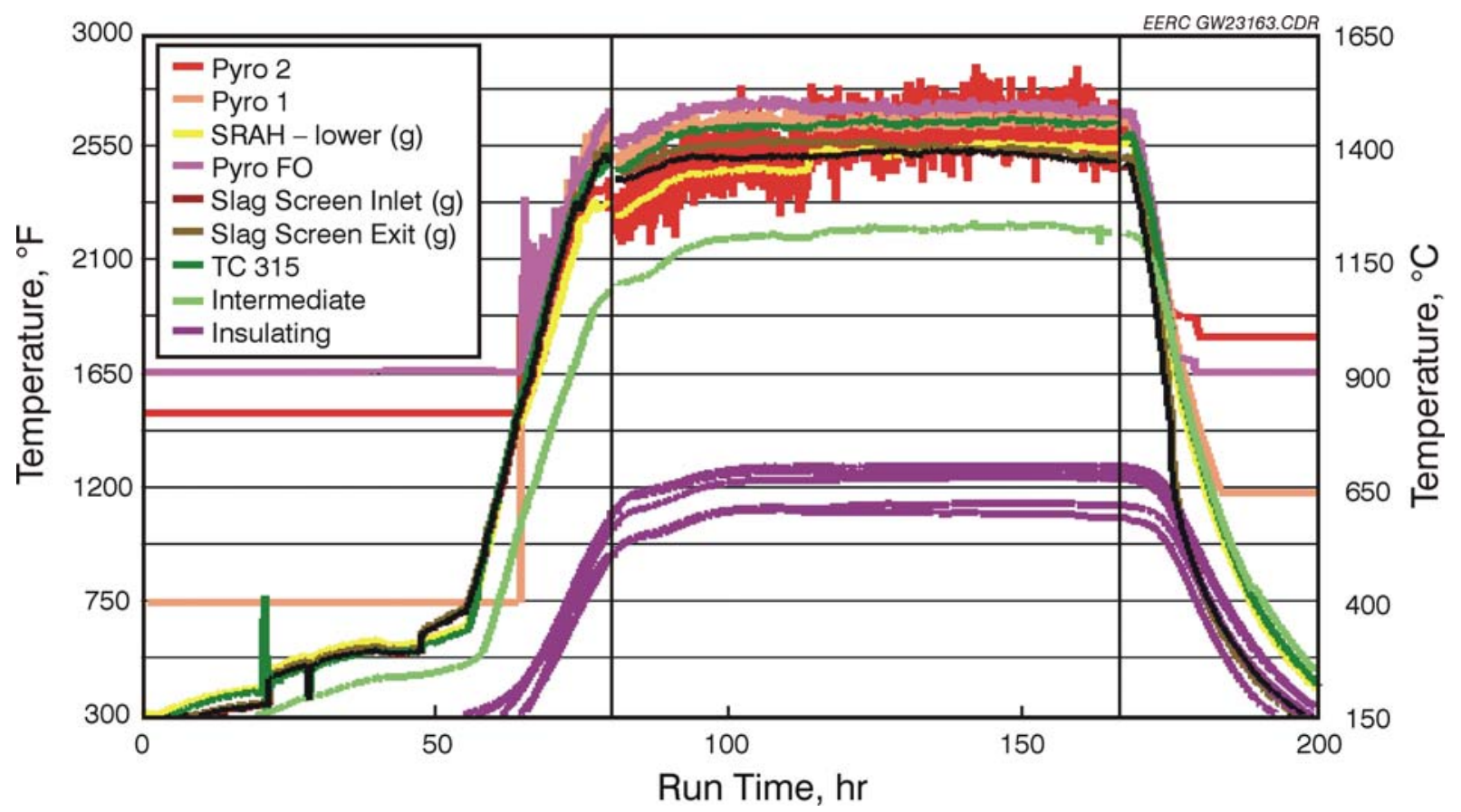

Figure 9. Furnace and slag screen temperatures versus run time for Test SFS-XCEL2-0403. 
The first trip forced a temporary reduction in coal feed rate to avoid overheating the HTHX alloy surfaces while the compressor was restarted, and air pressure recovered over a 15-min period. The second trip was adequately handled by the nitrogen backup system while the compressor was restarted, and a reduction in coal feed rate was not necessary. A reason for the compressor trips was not verified, but it is believed that they were caused by moisture in a compressor instrument air line that froze.

\section{Baghouse Performance}

The characteristics of the fly ash generated in the high-temperature SFS are different than those observed for a given fuel fired in a conventional pulverized coal (pc)-fired system. Specific differences observed include a reduction in mass loading and particle size and a higher concentration of alkaline-earth components. This shift in ash properties was anticipated based on the use of a slag screen at the furnace exit to promote ash collection as slag. Ash passing through the slag screen is expected to represent smaller ash particles as well as ash components volatilized in the furnace and subsequently condensed at lower temperatures downstream. Although evaluating baghouse performance was not a primary objective for this project, biomass cofiring had a significant impact on bag cleaning.

North Antelope subbituminous coal was the primary fuel fired in support of this project. However, the cofiring of three different biomass fuels did impact baghouse ash characteristics with the potential to affect baghouse performance. The bags used in support of this project were a 22-oz/yd $\mathrm{yd}^{2}\left(747-\mathrm{g} / \mathrm{m}^{2}\right)$ woven glass/polytetrafluoroethylene (PTFE) membrane fabric combination representing a total filtration area of $565 \mathrm{ft}^{2}\left(52.5 \mathrm{~m}^{2}\right)$. During previous projects firing bituminous and subbituminous coal, online cleaning was very effective, and particulate control was very good with this fabric type. Online pulse cleaning of the PTFE membrane bags has been successfully accomplished using reservoir pulse-air pressures of nominally 40-60 psig (2.8-4.1 bar) for previous bituminous and subbituminous coal-fired SFS tests. The baghouse differential pressure cleaning set point was 6 in. W.C. $(11.2 \mathrm{mmHg})$. Once the initial dust cake was formed, the cleaning frequency was 3-5 hr when an Illinois No. 6 bituminous coal was fired (with and without calcium oxide injection to control sulfur trioxide emissions) and nominally $2 \mathrm{hr}$ when a subbituminous coal was fired. The bags cleaned to a differential pressure of $<3$ in. W.C. $(<5.6 \mathrm{mmHg})$ when bituminous coal was fired and $<4$ in. W.C. $(<7.5 \mathrm{mmHg})$ when subbituminous coal was fired.

Baghouse temperatures ranged from $325^{\circ}$ to $345^{\circ} \mathrm{F}\left(163^{\circ}\right.$ to $\left.174^{\circ} \mathrm{C}\right)$ for Tests XCEL1 and $\mathrm{XCEL} 2$ and from $305^{\circ}$ to $330^{\circ} \mathrm{F}\left(152^{\circ}\right.$ to $\left.166^{\circ} \mathrm{C}\right)$ for Test XCEL3. Baghouse temperature was intentionally reduced somewhat for Test XCEL3 in an attempt to improve online bag cleaning. The filter face velocities for the three coal-biomass cofiring tests were $2.0-2.9 \mathrm{ft} / \mathrm{min}$ $(0.70-0.85 \mathrm{~m} / \mathrm{min})$. These filter face velocities are low compared to conventional pulse-jet filtration systems typically operating at or near $4 \mathrm{ft} / \mathrm{min}(1.2 \mathrm{~m} / \mathrm{min})$.

The online cleaning cycle trigger point was initially set at 6 in. W.C. (11.2 mmHg), and the first cleaning cycle occurred after nominally $6 \mathrm{hr}$ of coal-hog fuel cofiring. However, this initial cleaning cycle only reduced the differential pressure to $4.5 \mathrm{in}$. W.C. (8.4 mmHg). Over the first 
24 hours of coal-hog fuel cofiring, online cleaning became continuous, and differential pressure control was erratic. Therefore, the bags were cleaned off-line, and the cleaning cycle trigger point was increased to $7 \mathrm{in}$. W.C. (13.1 mmHg). Online cleaning was again attempted and found to be unsuccessful, forcing off-line cleaning. Increasing the trigger point to 8 and $9 \mathrm{in.} \mathrm{W.C.}$ (14.9 and $16.8 \mathrm{mmHg}$ ) also resulted in unsuccessful attempts to clean the bags online. Therefore, it was necessary to use off-line cleaning to control baghouse differential pressure while hog fuel was cofired, and cleaning frequency was 5-6 hours based on an off-line cleaning trigger point of 8-9 in. W.C. (14.9-16.8 mmHg). Results were similar when cofiring corn stover. However, cleaning frequency was $2-3$ hours based on an off-line cleaning cycle trigger point of nominally 8 in. W.C. (14.9 mmHg). Figure 10 illustrates the baghouse differential pressure data for Test XCEL2 while corn stover was cofired.

When switchgrass was cofired, the online cleaning cycle trigger point was initially set at 6 in. W.C. (11.2 mmHg), and the first cleaning cycle successfully reduced the differential pressure to $<2$ in. W.C. ( $<3.7 \mathrm{mmHg}$ ). However, online cleaning became less and less effective with each subsequent cleaning cycle. After 26 hours of coal-switchgrass cofiring, it was necessary to use off-line cleaning to control baghouse differential pressure. The off-line cleaning cycle trigger point was nominally 6 in. W.C. (11.2 mmHg), and cleaning frequency was 3-4 hours.

Since online baghouse cleaning had not been a problem previously when a subbituminous coal was fired, consideration was given to the potential impact of biomass cofiring. Nominally, $10 \%-15 \%$ of the ash in the fuels fired in the SFS reaches the baghouse. Baghouse ash recovered following the biomass-cofiring test periods represented $11 \%-14 \%$ of the total fuel ash. Particle-

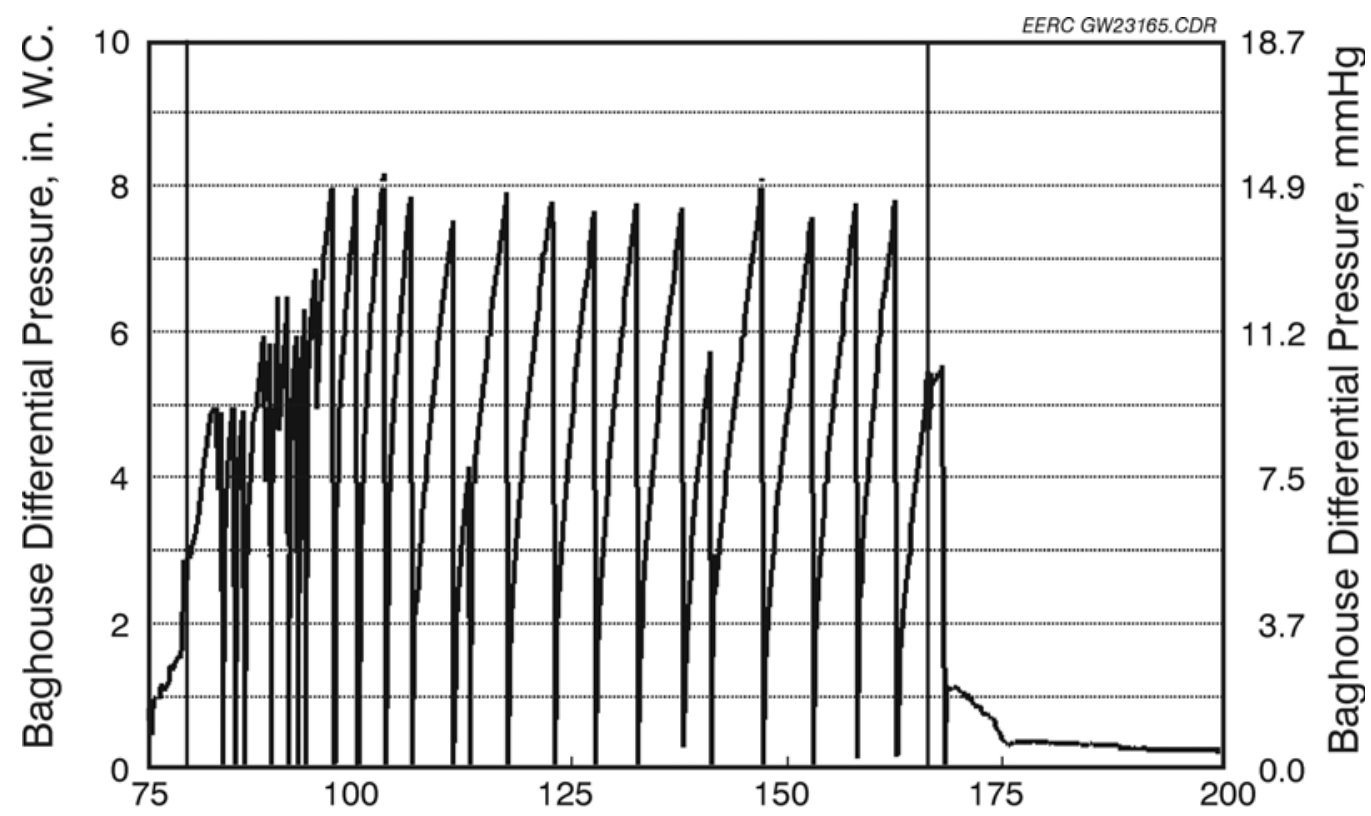

Run Time, hr

Figure 10. Baghouse differential pressure versus run time for Test SFS-XCEL-0403. 
size and chemical composition analyses were completed for a composite ash sample collected from the baghouse hopper for each biomass-cofiring test. Composition data for these samples show expected shifts in composition when baghouse ash is compared with the fuel ash for a slagging system. Specifically, concentrations of alkali components increase, while silica and alumina concentrations decrease. In addition, the alkali components are not highly sulfated, typically $<30$ mol\%. Table 4 summarizes the baghouse ash composition data for the three biomass-cofiring tests and a subbituminous coal previously fired in the SFS.

A comparison of the fuel ash composition data for the North Antelope (fired in support of this project) and a Cordero Rojo subbituminous coal (fired in support of a previous project) shows they are nearly identical. Therefore, any differences noted in the baghouse ash composition data would have to be a function of biomass cofiring. The primary difference in composition data is an order-of-magnitude or near-order-of-magnitude increase in the potassium content for the baghouse ash resulting from biomass cofiring. Phosphorus content is higher in two of the three biomass-cofiring ash samples, and sodium is higher in the third. Therefore, one factor likely contributing to online baghouse cleaning difficulties is an increase in the alkalineearth content of the ash, specifically potassium and sodium, and the presence of phosphorus. The potassium and sodium constituents would be expected to be highly sulfated. However, the $\mathrm{SO}_{3}$ content of the baghouse ash samples resulting from biomass cofiring is insufficient for sulfation levels of more than $16 \mathrm{~mol} \%$ (XCEL2) to $30 \mathrm{~mol} \%$ (XCEL1) of the total alkali content based on calcium, sodium, and potassium. The low degree of alkali sulfation is a direct result of the low

Table 4. Baghouse Bulk Ash Sample Analyses for Tests XCEL1, XCEL2, XCEL3, and a Previously Fired Subbituminous Coal ${ }^{1}$

\begin{tabular}{lcccc}
\hline Oxides, ${ }^{2}$ wt $\%$ & Cordero Rojo Coal & XCEL1 & XCEL2 & XCEL3 \\
\hline $\mathrm{SiO}_{2}$ & $21.2-22.0$ & 13.9 & 20.5 & 21 \\
$\mathrm{Al}_{2} \mathrm{O}_{3}$ & $16.1-16.9$ & 11.9 & 14.9 & 14.7 \\
$\mathrm{Fe}_{2} \mathrm{O}_{3}$ & 6.7 & 7.3 & 5.5 & 7 \\
$\mathrm{TiO}_{2}$ & 1.4 & 1 & 1.1 & 1.2 \\
$\mathrm{P}_{2} \mathrm{O}_{5}$ & 2 & 2.5 & 5.2 & 5.6 \\
$\mathrm{CaO}^{2}$ & $30.6-31.0$ & 26.6 & 28.6 & 28.2 \\
$\mathrm{MgO}^{2}$ & 5 & 5.6 & 6.9 & 6.4 \\
$\mathrm{Na}_{2} \mathrm{O}$ & $2.2-2.3$ & 5.8 & 2.3 & 2.1 \\
$\mathrm{~K}_{2} \mathrm{O}$ & 0.6 & 6.8 & 6 & 4.3 \\
$\mathrm{SO}_{3}$ & $12.6-13.7$ & 18.5 & 9 & 9.7 \\
\hline $1 \mathrm{Baghouse}_{2}$ Oxide concentrations normalized to $100 \%$ closure. & &
\end{tabular}


sulfur content of the coal (0.23-0.25 wt\%) and biomass fuels (0.04-0.13 wt\%) and the association of calcium with alumina and silicates.

SEM morphology analysis was completed for four composite baghouse ash samples, three resulting from the coal-biomass cofiring tests and one from a previous SFS test firing a Cordero Rojo subbituminous coal. Based on the data, the elemental composition of point analyses for spherical ash particles in the 1-2- $\mu \mathrm{m}$ size range is dominated by the major components identified in the bulk fuel ash analyses. These elements include silica and calcia, with smaller concentrations of alumina, iron oxide, and magnesia. Phosphorus appears to be associated with the calcium constituents. Single-point analyses of smaller nonspherical ash particles attached to the surface of the larger spherical particles or as a matrix between the larger ash particles showed a significant enrichment in potassium and sulfur for the coal-biomass-cofiring tests when compared to firing the Cordero Rojo subbituminous coal. Some sodium enrichment was also observed in the case of hog fuel cofiring (XCEL1). The highest degree of potassium enrichment was observed for corn stover cofiring (XCEL2), consistent with the bulk fuel data showing the corn stover to have the highest ash content and the highest potassium content in the ash. Calculated mole ratios based on the elemental analysis data indicate that the potassium and sodium are present as sulfates. These data support the theory that potassium sulfate formation and condensation were responsible for altering the cohesive properties of the baghouse ash resulting from coal-biomass cofiring when compared to previous subbituminous coal-fired tests and the difficulties encountered controlling baghouse differential pressure using online cleaning.

Another ash characteristic that can affect baghouse performance is particle-size distribution. Malvern analyses for the three biomass-cofiring tests and a baghouse ash resulting from the firing of the Cordero Rojo subbituminous coal indicated that the baghouse ash particle- size distribution was slightly larger for the three ash samples resulting from biomass cofiring, $100 \mathrm{wt} \%<8-11 \mu \mathrm{m}$ versus $100 \mathrm{wt} \%<7 \mu \mathrm{m}, 80 \mathrm{wt} \%<5-7 \mu \mathrm{m}$ versus $80 \mathrm{wt} \%<4.5 \mu \mathrm{m}$, and $50 \mathrm{wt} \%<3-4 \mu \mathrm{m}$ versus $50 \mathrm{wt} \%<2.5 \mu \mathrm{m}$. The slightly larger particle size for the ash resulting from biomass cofiring may be related to the larger particle size of the biomass fuels fired. Based on multicyclone sampling, the aerodynamic particle-size distribution resulting from biomass cofiring is within the range of values observed for subbituminous coal alone. Therefore, neither bulk ash nor instrument-measured particle-size distribution appears to be a contributing factor to the online baghouse-cleaning difficulties when biomass is cofired. However, visual inspection of SEM micrographs showed that nearly all of the ash particles resulting from biomass cofiring were $2 \mu \mathrm{m}$ and less. Therefore, the particle-size data based on Malvern analyses and multicyclone sampling may have been affected by the cohesive character of the ash particles and the formation of particle agglomerates.

Based on the fly ash data reviewed, online cleaning difficulties appear to be related to ash chemistry and a resulting inability to dislodge the dust cake from the bag surface. The slagging system magnifies the problem because of the reduced total mass loading to the baghouse and enrichment of alkali sulfates in the baghouse ash. In order to successfully control baghouse differential pressure with online cleaning, biomass cofiring would have to be reduced from the $20 \%$ cofiring rate used during these tests. Further testing would be required to determine if online cleaning would be possible at $15 \%, 10 \%$, or $5 \%$ biomass cofiring. 
Coal-biomass cofiring in a conventional pc-fired system, resulting in a dry ash condition, may not present online baghouse-cleaning difficulties for $20 \%$ biomass cofiring. The greater overall mass loading would result in a much lower degree of ash enrichment in alkali sulfates, and the larger average particle size would likely reduce particle cohesion characteristics. However, specific tests would be required to verify this observation. With respect to fly ash, the SFS produces a fly ash more representative of a cyclone-fired system than a conventional pcfired system.

Particulate mass-loading measurements were made at the inlet and outlet of the baghouse in support of this project. Baghouse inlet mass-loading values for the three biomass-cofiring tests ranged from 0.1275 to $0.1713 \mathrm{gr} / \mathrm{scf}\left(0.2920\right.$ to $\left.0.3923 \mathrm{~g} / \mathrm{m}^{3}\right)$. These values are at least an order of magnitude lower than would be expected in a conventional pc-fired system. This is a direct result of the ash removal as slag in the slag screen. The lowest baghouse inlet mass loading was observed for Test XCEL1, consistent with the hog fuel having the lowest ash content of the three biomass fuels cofired and XCEL1 having the highest flue gas flow rate as a result of hog fuel moisture content and auxiliary burner-firing rate. The highest baghouse inlet mass loading was observed for Test XCEL3, consistent with XCEL3 having the lowest flue gas flow rate as a result of a low switchgrass moisture content and auxiliary burner-firing rate. Differences in baghouse inlet mass loading were mostly the result of differences in flue gas volumetric flow rate. Baghouse inlet mass-loading ranges were found to overlap when the biomass-cofiring tests were compared with a previous test firing Cordero Rojo subbituminous coal.

Baghouse outlet mass-loading values for the three biomass-cofiring tests ranged from 0.0000 to $0.0011 \mathrm{gr} / \mathrm{scf}\left(0.0000\right.$ to $\left.0.0025 \mathrm{~g} / \mathrm{m}^{3}\right)$. The lowest baghouse outlet mass loadings were observed for Tests XCEL2 and XCEL3, both resulting in no measurable particulate emissions. Based on postrun maintenance activities, the particulate emissions rate measured for Test XCEL1 may have been affected by one bag that was found to be improperly mounted in the tube sheet, potentially creating a minor flue gas leak through the tube sheet. Sampling results for Tests XCEL2 and XCEL3 showing no mass emissions at the outlet of the baghouse were not expected.

Although low mass emissions have been previously observed, zero values have not. Possible contributing factors to the zero mass-loading values include high differential pressures, low filter face velocities, and the need for off-line cleaning; sampling periods do not reflect spikes in mass emissions as a function of cleaning cycles. The lowest mass loading and emission rate previously observed were $0.0001 \mathrm{gr} / \mathrm{scf}\left(0.0002 \mathrm{~g} / \mathrm{m}^{3}\right)$ and $0.0004 \mathrm{lb} / \mathrm{MMBtu}$ when a Rochelle subbituminous coal was fired. Therefore, if the baghouse differential pressure control problem observed during the biomass-cofiring tests is solved, online cleaning will likely result in mass loadings of $<0.001 \mathrm{gr} / \mathrm{scf}\left(<0.002 \mathrm{~g} / \mathrm{m}^{3}\right)$ and mass emissions of $<0.003 \mathrm{lb} / \mathrm{MMBtu}$.

Assuming baghouse differential pressure can be controlled using online pulse cleaning as a result of operating parameter changes or a reduced biomass-cofiring rate in the slagging furnace system, the cohesive character of the ash may be beneficial. Specifically, the cohesive nature of the ash may reduce emission spikes as a function of cleaning cycle. This benefit would also be likely in a conventional dry ash pc-fired system. 


\section{CAH Results}

CAH tube bank performance has met all objectives relative to heat transfer and its support of the HTHX panel during this as well as previous projects. Performance differences relative to fuel ash properties were as expected. The potential effectiveness of sootblowing was not addressed during this project because the EERC elected to permit the formation of ash deposits on CAH tube bank surfaces in order to develop deposits for subsequent recovery and characterization. Based on CAH operating experience in support of previous projects, an 8-hr sootblowing frequency is adequate for an eastern Kentucky bituminous coal fired in the SFS. However, all of the other fuel types (bituminous, subbituminous, and lignite), including the North Antelope subbituminous coal fired in support of this project, would likely require more frequent (4-hr cycle) sootblowing to achieve a comparable result.

While natural gas was fired and the tubes were clean, heat recovery from the CAH tube bank was roughly $41,000 \mathrm{Btu} / \mathrm{hr}(43,255 \mathrm{~kJ} / \mathrm{hr})$. This result was observed for a process air flow rate of $125 \mathrm{scfm}\left(3.5 \mathrm{~m}^{3} / \mathrm{min}\right)$, inlet process air temperature of $1000^{\circ} \mathrm{F}\left(538^{\circ} \mathrm{C}\right)$, outlet process air temperature of $1170^{\circ} \mathrm{F}\left(633^{\circ} \mathrm{C}\right)$, and flue gas temperature of $1800^{\circ} \mathrm{F}\left(983^{\circ} \mathrm{C}\right)$ entering the $\mathrm{CAH}$ tube bank. When coal-biomass cofiring began, leading-edge surface temperatures initially decreased at rates of nominally $8^{\circ}-10^{\circ} \mathrm{F} / \mathrm{hr}\left(4^{\circ}-6^{\circ} \mathrm{C} / \mathrm{hr}\right)$ over $25 \mathrm{hr}$ as ash deposits developed on the surface of the tubes. Because sootblowing was not employed during these tests, surface temperatures continued to trend lower, to nominally $855^{\circ}-970^{\circ} \mathrm{F}\left(458^{\circ}-521^{\circ} \mathrm{C}\right)$. It must be noted that process air flow rates were adjusted somewhat during the coal-biomass cofiring test periods in an attempt to maintain process air exit temperature in the range of $900^{\circ}-1000^{\circ} \mathrm{F}$ $\left(483^{\circ}-538^{\circ} \mathrm{C}\right)$. The maximum and minimum process air flow rates through the CAH tube bank were $150 \mathrm{scfm}\left(4.2 \mathrm{~m}^{3} / \mathrm{min}\right)$ and $120 \mathrm{scfm}\left(3.4 \mathrm{~m}^{3} / \mathrm{min}\right)$, respectively. As ash deposits developed on the tube surfaces, heat recovery from the $\mathrm{CAH}$ tube bank decreased from maximum values of 41,200 - 45,400 Btu/hr (43,466 to 47,897 kJ/hr), for inlet and outlet process air temperatures of $930^{\circ}$ to $1010^{\circ} \mathrm{F}\left(499^{\circ}-544^{\circ} \mathrm{C}\right)$ and $1220^{\circ}-1270^{\circ} \mathrm{F}\left(660^{\circ}-688^{\circ} \mathrm{C}\right)$ to a minimum of 18,300 23,200 Btu/hr (19,306 to 24,476 kJ/hr), for inlet and outlet process air temperatures of $695^{\circ}-855^{\circ} \mathrm{F}\left(369^{\circ}-458^{\circ} \mathrm{C}\right)$ and $830^{\circ}-1000^{\circ} \mathrm{F}\left(444^{\circ}-538^{\circ} \mathrm{C}\right)$, respectively. Figure 11 summarizes the CAH heat recovery data for the three coal-biomass-cofiring tests.

The CAH deposits that formed during the coal-biomass-cofiring tests were limited to the leading and trailing edges of the tubes. Figure 12 is a photograph of ash deposits (without sootblowing) on the surface of the tubes following Test XCEL2 illustrating observations for all three test periods. The photograph shows substantial leading-edge deposition on uncooled and cooled tubes in the gas path with less trailing-edge deposition. The cooled tubes visible in the photograph (two tubes on the right side of the photograph) show the leading-edge deposits to be intact and uniform. However, these deposits were found to be highly friable when attempting to recover samples for characterization. CAH tube bank plugging was not a problem when the North Antelope coal and one of the three biomass fuels were cofired. No deposits were observed bridging the flue gas path between the tubes. 


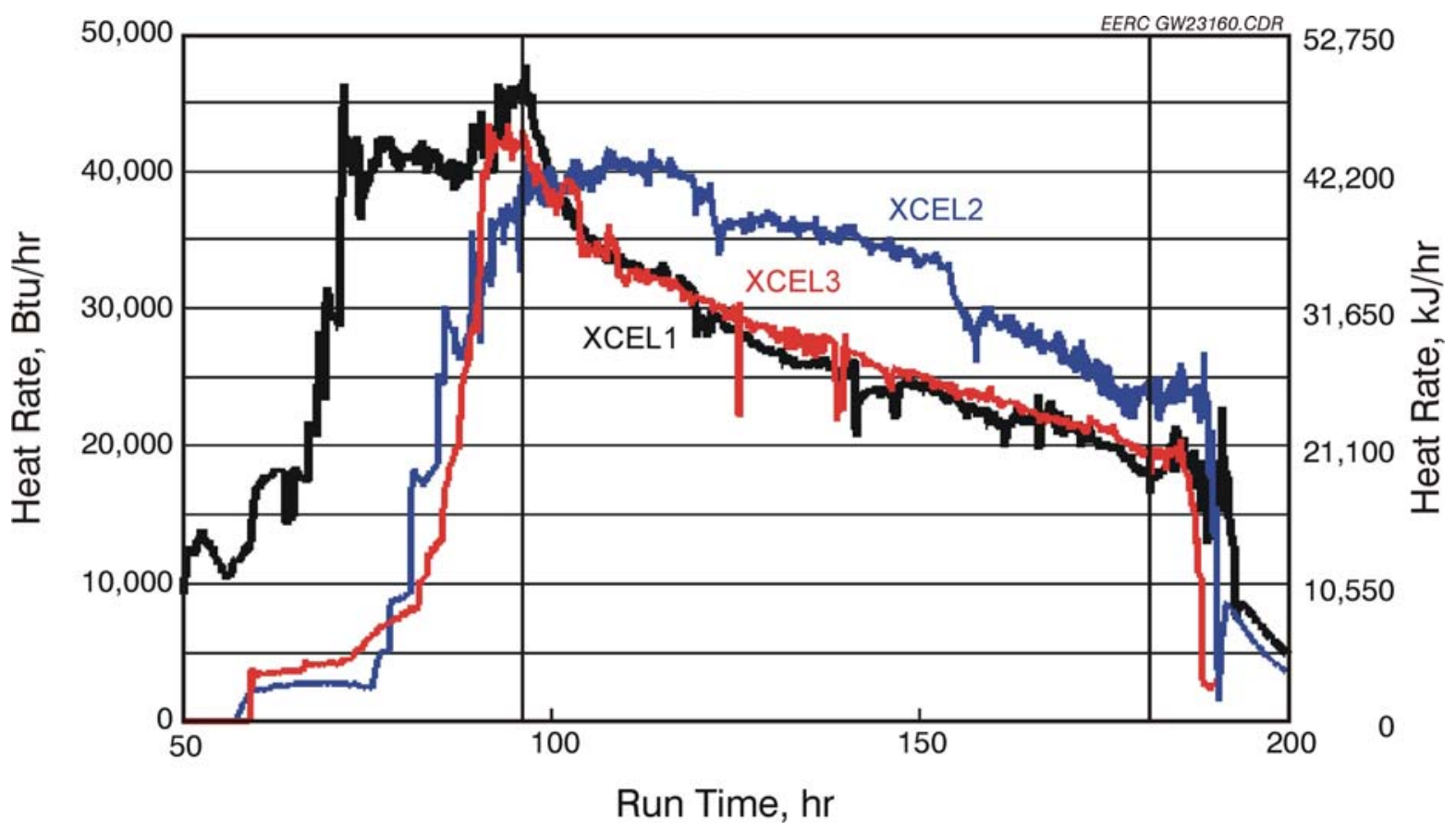

Figure 11. CAH heat recovery versus run time for the coal-biomass cofiring tests.

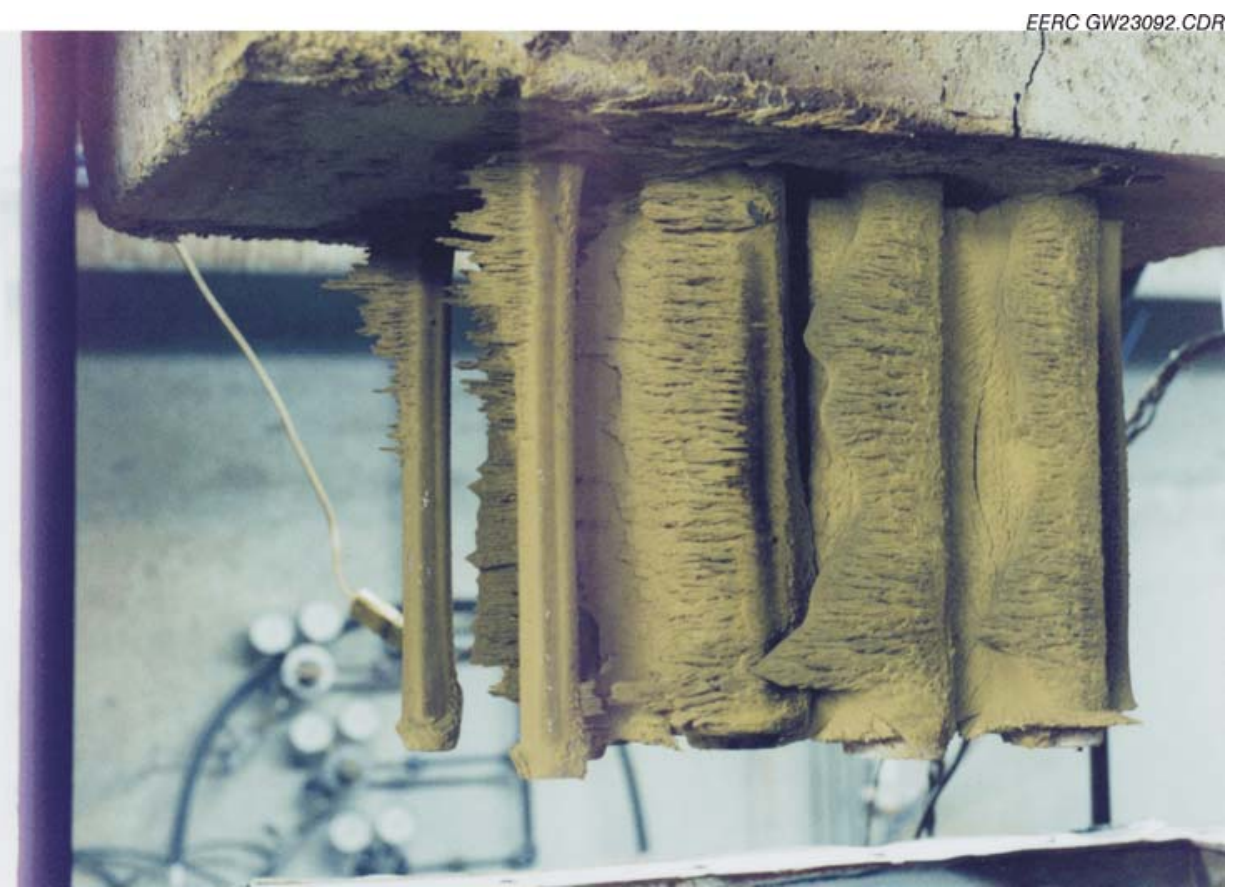

Figure 12. Photograph of ash deposits on the surface of the tubes following Test XCEL2. 
Deposit strength is a function of ash chemistry, particle size, and temperature history. The relative strength of the deposits formed when the North Antelope coal and the three biomass fuels were cofired was indicated by the fact that the deposits on the cooled tube surfaces tended to fall apart when ash deposits were recovered for characterization. The deposits tended to break up, even with careful handling. Because sootblowing was not attempted during these tests, a total mass was determined for the ash deposits associated with the CAH tubes. The total weight of the deposits collected from the CAH tubes ranged from 7 to $10 \mathrm{lb}$ (3.2 to $4.5 \mathrm{~kg}$ ). On a mass-perunit-time basis, the ash deposition rates were $0.082-0.116 \mathrm{lb} / \mathrm{hr}(36.3-52.8 \mathrm{~g} / \mathrm{hr})$. Incorporating the surface area of the tube bank $\left(6.28 \mathrm{ft}^{2}\right.$ or $\left.0.58 \mathrm{~m}^{2}\right)$ results in values of $0.013-0.018 \mathrm{lb} / \mathrm{hr}-\mathrm{ft}^{2}$ $\left(62.6-91.0 \mathrm{~g} / \mathrm{hr}^{-\mathrm{m}^{2}}\right)$. These calculated values are essentially the same as results for other subbituminous coal-fired SFS test periods, $0.017 \mathrm{lb} / \mathrm{hr}^{-\mathrm{ft}^{2}}\left(78.3 \mathrm{~g} / \mathrm{hr}-\mathrm{m}^{2}\right)$, previously completed. On a coal-biomass-cofiring-rate basis, the CAH ash deposition rates were 0.03-0.053 lb/MMBtu $\left(15.8-23.0 \mathrm{~g} / 10^{6} \mathrm{~kJ}\right)$. CAH ash deposition rates followed biomass fuel ash content. However, coal-hog fuel cofiring resulted in a slightly lower ash deposition rate because of the slag screen plugging observed during the test, resulting in a lower ash mass loading reaching the CAH tube bank. Specifically, the corn stover, switchgrass, and hog fuel ash contents were 7.1, 5.4, and $5.0 \mathrm{wt} \%$, respectively, with corn stover cofiring resulting in the highest ash deposition rate. There was no slag screen plugging observed when the corn stover or switchgrass was cofired.

Based on previous experience firing subbituminous coal, if sootblowing had been employed during these coal-biomass cofiring tests, it is likely CAH heat recovery would have been maintained in the range of 32,500-40,000 Btu/hr (34,290-42,200 kJ/hr). A comparison of the $\mathrm{CAH}$ heat-transfer data for the three coal-biomass cofiring tests (Figure 11) indicates that the results when hog fuel and switchgrass were cofired were very similar. When corn stover was cofired, the initial increase in CAH heat recovery after initiating solid fuel cofiring resulted from increasing furnace firing rate and the resulting increase in furnace exit temperature and flue gas flow rate. During this same time frame, slag screen differential pressure was decreasing as slag (accumulated as a result of hog fuel cofiring) began to flow from the slag screen to the slag tap. However, the CAH heat recovery rate when corn stover was fired did not degrade to $<20,000 \mathrm{Btu} / \mathrm{hr}(<21,100 \mathrm{~kJ} / \mathrm{hr})$ as was observed for the hog fuel and switchgrass. There is no obvious explanation for this difference based on flue gas or process air temperatures and flow rates. One possible explanation may be related to the density of the ash deposits formed.

One of the standards of success identified for this project in the original proposal was the production of clean pressurized air at $1300^{\circ} \mathrm{F}\left(705^{\circ} \mathrm{C}\right)$ with the $\mathrm{CAH}$ while limiting convective pass flue gas temperature to $1850^{\circ} \mathrm{F}\left(1010^{\circ} \mathrm{C}\right)$. Based on the temperature measurements made during the three coal-biomass cofiring tests, clean pressurized air temperatures generally stabilized at $950^{\circ}-1000^{\circ} \mathrm{F}\left(510^{\circ}-538^{\circ} \mathrm{C}\right)$ near the end of each test. At face value, these data would indicate that the proposed standard of success was not achieved. However, this result was a function of several factors. First, the $\mathrm{CAH}$ was originally designed to preheat $100 \mathrm{scfm}$ $\left(3.4 \mathrm{~m}^{3} / \mathrm{min}\right)$ of process air from $1000^{\circ}$ to $1300^{\circ} \mathrm{F}\left(538^{\circ}\right.$ to $\left.705^{\circ} \mathrm{C}\right)$ in support of the original HTHX configuration. Since then, changes in the HTHX configuration have required an increase in the volume of process air supporting the HTHX, but the CAH surface area was not increased to handle the additional process air volume because there was nothing new to be learned from 
the CAH in terms of heat transfer. During the coal-biomass cofiring tests, the CAH process air flow rates were 120-150 scfm (3.4-4.2 $\left.\mathrm{m}^{3} / \mathrm{min}\right), 20 \%-50 \%$ greater than the original design basis. Second, no attempt was made to routinely sootblow the CAH surfaces in order to develop ash deposits for characterization; therefore, CAH outlet process air temperatures decreased as a function of ash deposition on heat-transfer surfaces. Finally, because of the higher flow rate through the preheaters, $\mathrm{CAH}$ inlet process air temperatures were nominally $300^{\circ} \mathrm{F}\left(167^{\circ} \mathrm{C}\right)$ lower than the design basis. Therefore, based on previous HTHX tests and the data generated during the coal-biomass cofiring tests, reducing the process air flow rate to design volumes or adding sufficient CAH surface and surface to adequately preheat process air upstream of the $\mathrm{CAH}$ would easily result in $\mathrm{CAH}$ outlet process air temperatures of $1300^{\circ} \mathrm{F}\left(705^{\circ} \mathrm{C}\right)$.

\section{HTHX Results}

For the coal-biomass cofiring tests, only one alloy tube surface thermocouple was directly exposed to furnace conditions. Because of changes in the original HTHX configuration, all remaining alloy surface thermocouples as well as the lower half and upper $11 \%$ of the HTHX were encased in insulation and refractory, shielding them from furnace conditions. No attempt was made to sootblow or clean the HTHX tubes online during any test period. Based on predicted and observed surface temperatures, the EERC expected the HTHX alloy surfaces to be self-cleaning, such that as slag deposits formed and accumulated on the furnace side of the tubes, they would flow down the surface of the tubes.

During a short 16-hr natural gas-fired test period prior to initiating coal-biomass cofiring, process air temperatures of $1410^{\circ}-1470^{\circ} \mathrm{F}\left(766^{\circ}-799^{\circ} \mathrm{C}\right)$ were achieved at the HTHX exit based on process air flow rates of 370-386 scfm $\left(10.5-10.9 \mathrm{~m}^{3} / \mathrm{min}\right)$, furnace firing rates of 3.0-3.2 MMBtu/hr $\left(3.2-3.4 \times 10^{6} \mathrm{~kJ} / \mathrm{hr}\right)$, and a furnace exit temperature of $2730^{\circ}-2795^{\circ} \mathrm{F}$ $\left(1499^{\circ}-1535^{\circ} \mathrm{C}\right)$. Inlet process air temperatures were $1070^{\circ}-1105^{\circ} \mathrm{F}\left(577^{\circ}-596^{\circ} \mathrm{C}\right)$. HTHX heat recovery in this case was 396,400-439,900 Btu/hr (418,200-464,100 kJ/hr) when corrected for surface area. These values are consistent with data observed for other natural gas-fired test periods at comparable firing rates and furnace temperatures.

HTHX process air flow rates during the coal-biomass-cofiring tests were controlled at set points of 375, 380, 390, and $395 \mathrm{scfm}\left(10.6,10.8,11.0\right.$, and $\left.11.2 \mathrm{~m}^{3} / \mathrm{min}\right)$, but were typically 385 to $395 \mathrm{scfm}$ (10.9 to $\left.11.2 \mathrm{~m}^{3} / \mathrm{min}\right)$. Changes in process air flow rate were minimized in an attempt to achieve thermal stability during each 85-hr coal-biomass-cofiring test period and to maintain HTHX tube surface temperature in a specified range. The original test plan limited the maximum HTHX tube surface temperature to $<1925^{\circ} \mathrm{F}\left(<1052^{\circ} \mathrm{C}\right)$ while coal and biomass were cofired. Generally, the HTHX tube surface temperature limit was maintained. However, the control thermocouple did fail during each test period, and two compressor trips resulted in minor temperature spikes. Therefore, other thermocouples, both process air and tube surface, were used to adjust furnace firing rate and process air flow rate to avoid overheating the HTHX. As a result, maximum HTHX tube surface temperatures were controlled at $<1930^{\circ} \mathrm{F}\left(1055^{\circ} \mathrm{C}\right)$ and typically ranged from $1890^{\circ}$ to $1920^{\circ} \mathrm{F}\left(1033^{\circ}\right.$ to $\left.1049^{\circ} \mathrm{C}\right)$. The range of measured alloy surface temperatures protected from furnace conditions decreased from nominally $1070^{\circ}-1670^{\circ} \mathrm{F}$ $\left(577^{\circ}-905^{\circ} \mathrm{C}\right)$ to $950^{\circ}-1595^{\circ} \mathrm{F}\left(510^{\circ}-869^{\circ} \mathrm{C}\right)$. The low end of these temperature ranges represent 
the back side of the tube surfaces near the process air inlet, with the high end of the temperature ranges representing the front side of the tube surfaces near the midpoint immediately beneath the insulating material and high-density refractory used to isolate the lower half of the HTHX.

Tube surface temperatures during the coal-biomass-cofiring tests were generally lower than values observed for previous HTHX tests $\left(230^{\circ}-400^{\circ} \mathrm{F}\left[110^{\circ}-205^{\circ} \mathrm{C}\right]\right)$ because of the lower alloy surface temperature limit selected for the coal-biomass-cofiring tests to assure that no molten ash would be in contact with the tubes. As the tests progressed, the HTHX surface temperatures decreased as a direct result of ash/slag deposition on alloy tube surfaces and the decreasing process air inlet temperature resulting from ash deposition on CAH and air preheat surfaces. Deposition on the HTHX alloy tube surfaces began with a low-density sintered layer, followed by a higher-density intermediate layer, and finally a high-density molten slag layer. It is important that the inner layer not be molten to minimize corrosion of the tubes. However, it may be possible to allow a somewhat higher surface temperature and still have a dry ash surface layer. Also, the slag layer did not build to the point that it began to flow down the surface of the alloy tubes. Based on these observations, a longer test period firing solid fuel is required to reach steady-state heat-transfer rates while these fuel combinations were fired.

During the coal-biomass-cofiring tests, the range of measured process air temperatures at the exit of the $\mathrm{HTHX}$ decreased from nominally $1330^{\circ}-1380^{\circ} \mathrm{F}\left(721^{\circ}-749^{\circ} \mathrm{C}\right)$ to $1175^{\circ}-1230^{\circ} \mathrm{F}$ $\left(635^{\circ}-666^{\circ} \mathrm{C}\right)$. This decrease is a direct result of decreasing heat transfer caused by ash/slag deposition on HTHX alloy tube surfaces as well as ash deposition on downstream heat-transfer surfaces (CAH and air preheat surfaces). Differences in HTHX outlet process air temperatures between individual coal-biomass-cofiring tests were consistent with a combination of furnace temperature and process air flow rates. Inlet process air temperatures ranged from $930^{\circ}$ to $1070^{\circ} \mathrm{F}\left(499^{\circ}\right.$ to $\left.577^{\circ} \mathrm{C}\right)$ during the coal-biomass cofiring tests. Differences in HTHX inlet process air temperatures were consistent with the ash deposition rates observed in the CAH for the hog fuel (0.036 lb/MMBtu), corn stover (0.053 lb/MMBtu), and switchgrass (0.044 $\mathrm{lb} / \mathrm{MMBtu}$ ). However, these differences would likely be mitigated if an effective routine sootblowing methodology were applied to the CAH and downstream process air preheat surfaces.

Heat recovery data from the HTHX are presented in Figure 13 for the coal-biomasscofiring tests. Measured heat recovery decreased from 138,400-156,000 Btu/hr $(146,010-164,580 \mathrm{~kJ} / \mathrm{hr})$ to nominally $114,300-137,700 \mathrm{Btu} / \mathrm{hr}(120,590-145,270 \mathrm{~kJ} / \mathrm{hr})$ during the coal-biomass-cofiring test periods as a result of ash and slag deposition on the HTHX alloy tube surfaces. Assuming that HTHX thermal stability was achieved during the last $8 \mathrm{hr}$ of the each test period, the measured heat recovery observed during the coal-biomass cofiring tests is comparable if not greater than the average level of heat recovery $(120,000 \mathrm{Btu} / \mathrm{hr}$ [126,600 kJ/hr]) previously observed when evaluating the HTHX/radiative air heater (RAH) in a tile-protected configuration. Correcting the coal-biomass-cofiring data to account for isolation of the lower half and upper $11 \%$ of the HTHX from furnace conditions results in an equilibrium heat recovery rate of 277,200-353,200 Btu/hr (292,450-372,630 kJ/hr).

As compared to earlier tests performed in a different program firing only coal, the corrected HTHX heat recovery rates for coal-biomass cofiring tests were $66 \%-84 \%$ of that observed for 


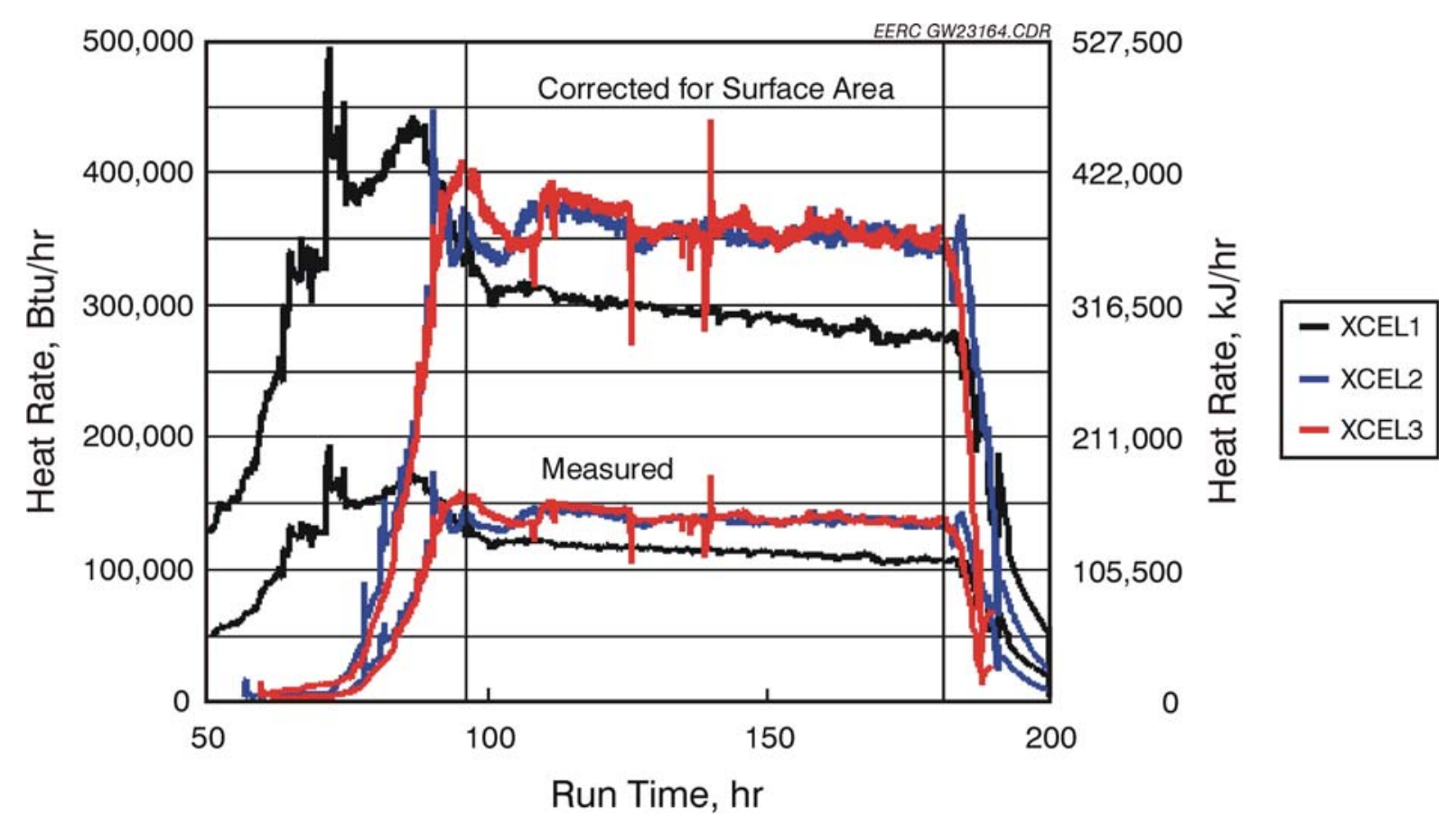

Figure 13. Measured and surface area-corrected HTHX heat recovery data for the coal-biomass-cofiring tests.

coal-only Test HTHX3, 277,200-353,200 versus 418,000 Btu/hr (292,450-372,630 versus $440,990 \mathrm{~kJ} / \mathrm{hr}$ ). The primary reason for this difference was furnace temperature, $2610^{\circ}-2710^{\circ} \mathrm{F}$ $\left(1433^{\circ}-1488^{\circ} \mathrm{C}\right)$, for the biomass-cofiring tests versus $2860^{\circ} \mathrm{F}\left(1571^{\circ} \mathrm{C}\right)$ for Test HTHX3 firing an Illinois No. 6 bituminous coal. As previously stated, furnace temperature during the coal-biomass-cofiring tests was reduced because of fuel ash/slag properties and a desire to avoid any potential alloy corrosion. However, at an equivalent furnace temperature, HTHX heat recovery during the coal-biomass-cofiring tests was comparable to previous HTHX tests firing only coal.

Comparisons of heat recovery data for the coal-biomass-cofiring test periods showed that for a process air flow rate of $390 \mathrm{scfm}\left(11.0 \mathrm{~m}^{3} / \mathrm{min}\right)$, heat recovery was $27 \%$ greater for the switchgrass test and $24 \%$ greater for the corn stover test when compared to the hog fuel test. The reason for the difference in heat recovery rates for the three biomass fuels was furnace temperature, $2710^{\circ} \mathrm{F}\left(1488^{\circ} \mathrm{C}\right), 2690^{\circ} \mathrm{F}\left(1477^{\circ} \mathrm{C}\right)$, and $2610^{\circ} \mathrm{F}\left(1433^{\circ} \mathrm{C}\right)$ for the switchgrass, corn stover, and hog fuel, respectively.

Ash and slag deposits did form on the HTHX alloy tubes during each test. However, during cooldown, the slag layer consistently fractured on the surface of the alloy tubes. As a result, the slag layers had cracked and either partially or completely fallen off of the tubes. Visual examination of the tube surfaces beneath the slag layer revealed a sintered ash layer. No evidence of slag flow down the surface of the alloy tubes was visible. Figure 14 is a photograph of the HTHX following Test XCEL2 cofiring corn stover illustrating these observations. 


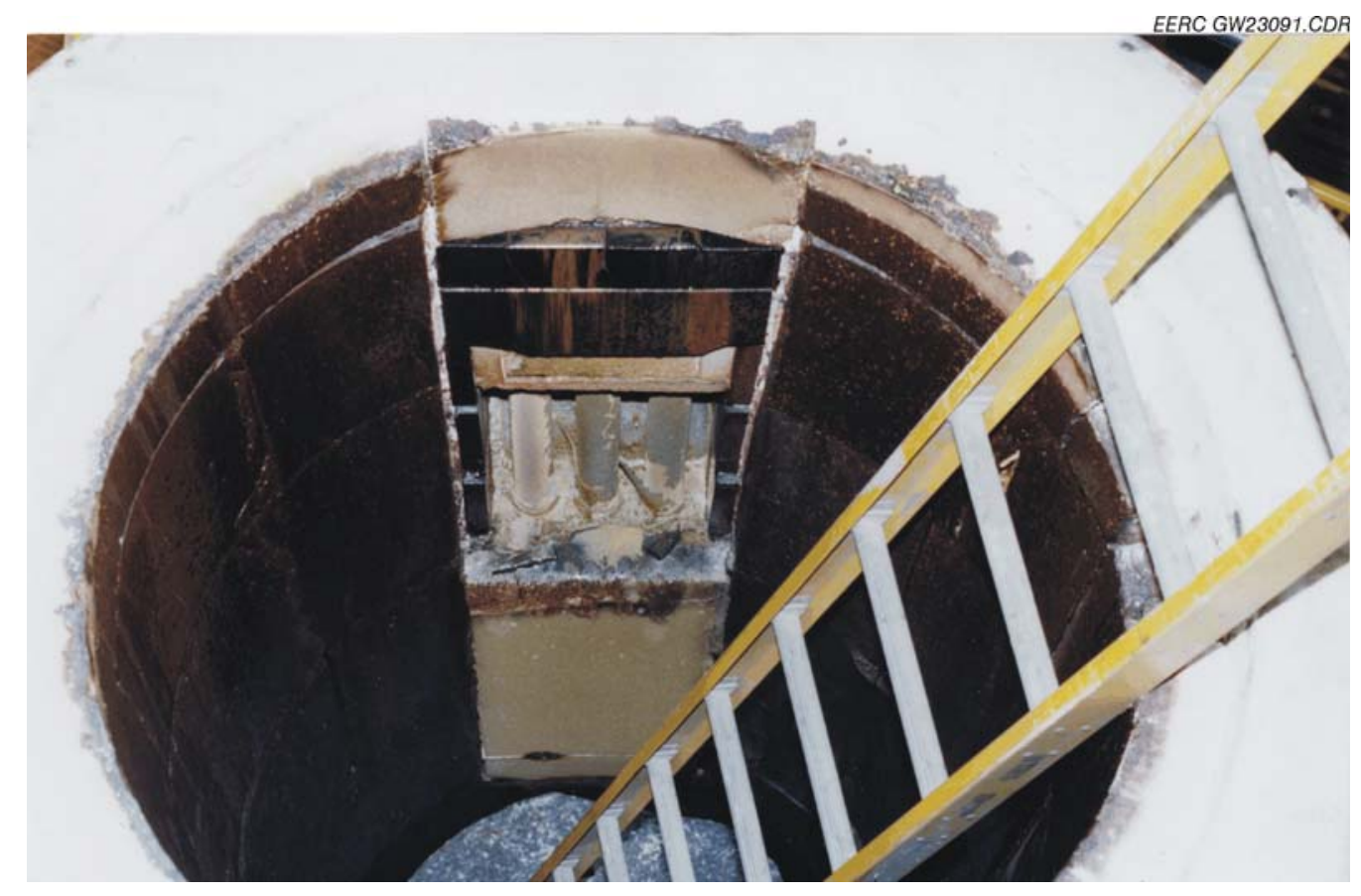

Figure 14. Photograph of the HTHX following Test XCEL2.

Figure 15 summarizes the air-blown heat recovery data on an equivalent-surface-area basis for the biomass-cofiring tests and several previous air-blown test periods evaluating the current HTHX configuration (known as the bare-tube configuration), as well as the original HTHX configuration (known as the tubes-in-a-box configuration). Data resulting from the biomasscofiring tests are represented by closed diamond symbols and represent $39 \%$ of the alloy surface exposed to furnace conditions. Data for furnace temperatures up to $2550^{\circ} \mathrm{F}\left(1399^{\circ} \mathrm{C}\right)$ represent results for $100 \%$ of the alloy surface exposed to furnace conditions. Data for furnace temperatures $>2550^{\circ} \mathrm{F}\left(>1399^{\circ} \mathrm{C}\right.$ ) from previous natural gas- and coal-fired tests represent results for $50 \%$ of the alloy surface exposed to furnace conditions. The data from previous natural gasfired bare-tube configuration tests are represented by open symbols connected by lines. Previous bare-tube configuration data from coal-fired tests are simply open symbols. Data resulting from the original tubes-in-a-box configuration are represented by closed symbols in the lower right corner of the figure.

Based on these data, if an adequate volume of process air were available to avoid overheating the alloy surfaces with $100 \%$ of the surface exposed to furnace conditions, the actual heat recovery rate for the bare-tube HTHX configuration may be $25 \%$ higher than the values reported for furnace temperatures $>2550^{\circ} \mathrm{F}\left(>1399^{\circ} \mathrm{C}\right)$. The basis for this belief is the HTHX location in the furnace wall relative to the downfired burner location in the top of the furnace and the potential for the lower half of the HTHX to visually see a greater percentage of the flame resulting in greater radiant heat transfer. Proving this theory will only be possible when sufficient process air can be made available to protect alloy tube surfaces from overheating with 


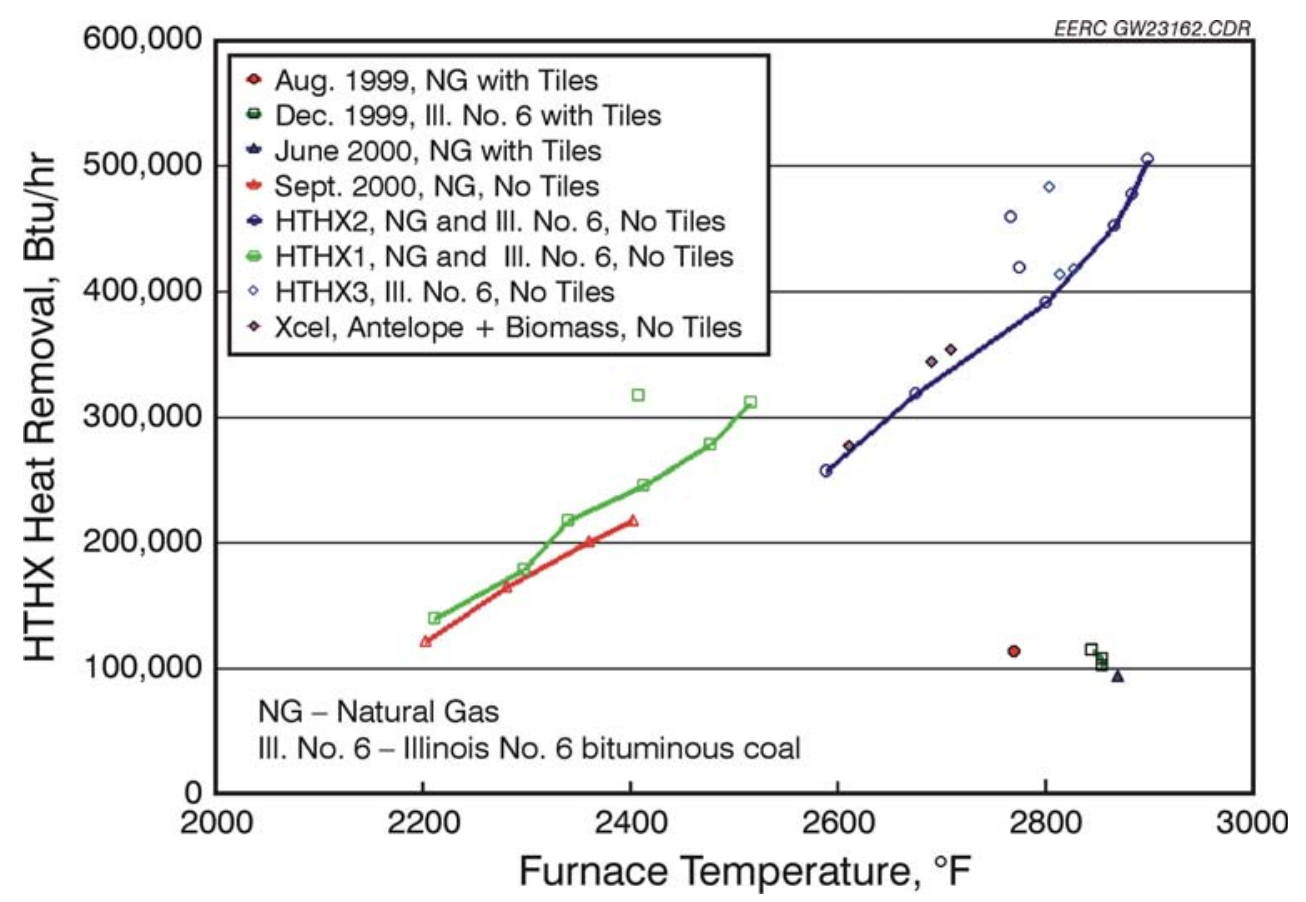

Figure 15. HTHX heat recovery (air-blown) versus furnace temperature on an equivalentsurface-area basis.

the entire HTHX exposed to furnace conditions while operating at furnace-firing rates and temperatures comparable to previous tests evaluating the tubes-in-a-box HTHX configuration.

Comparing the bare-tube and tubes-in-a-box heat recovery data indicates a significant advantage for the bare-tube configuration. The data clearly show that for furnace temperatures of nominally $2800^{\circ}-2900^{\circ} \mathrm{F}\left(1538^{\circ}-1594^{\circ} \mathrm{C}\right)$, removing the ceramic tiles/panels from the HTHX increases the heat recovery rate by nearly a factor of five. This means that the bare-tube configuration could be as small as one-fifth of that originally proposed in the UTRC hightemperature advanced furnace (HITAF) concept. Factoring in the savings realized by eliminating the ceramic tiles/panels, the cost of the bare-tube configuration may be one-tenth of the original tubes-in-a-box design.

Solid fuel-fired tests with the bare-tube configuration indicate that the more radiant coal or coal-biomass flame resulted in higher heat recovery rates as anticipated. However, ash and slag deposition on the alloy tubes appears to degrade the heat recovery rate to a level equivalent to natural gas firing.

Even at the lower furnace temperatures resulting from coal-biomass cofiring, HTHX heat recovery (on an equivalent-surface-area basis) was a factor of 2.3-3.0 greater than the heat recovery rate observed for the tubes-in-a-box HTHX configuration. For the bare-tube HTHX configuration, coal-biomass cofiring resulted in HTHX heat recovery rates consistent with previous tests firing natural gas and bituminous coal. Therefore, at comparable furnace 
temperatures, coal-biomass cofiring does not present any unique impediments to HTHX heat recovery. However, possibly lower biomass ash/slag melting temperatures may limit furnace temperatures and HTHX alloy surface temperatures. In that event, it is not likely that HTHX heat recovery rates observed for bituminous coal can be practically achieved when cofiring biomass.

One of the "standards of success" identified for this project in the original proposal was the production of clean pressurized air at $1700^{\circ} \mathrm{F}\left(927^{\circ} \mathrm{C}\right)$, while the slagging furnace was operated at a temperature of no more than $2850^{\circ} \mathrm{F}\left(1566^{\circ} \mathrm{C}\right)$. Based on the temperature measurements made during the three coal-biomass-cofiring tests, clean pressurized air temperatures generally stabilized at $1175^{\circ}-1230^{\circ} \mathrm{F}\left(635^{\circ}-666^{\circ} \mathrm{C}\right)$ near the end of each test. At face value, these data would indicate that the proposed standard of success was not achieved. However, this result was a function of several factors. First, $61 \%$ of the HTHX surface was isolated from furnace conditions, limiting the heat-transfer surface available to raise air temperature because of limited process air capacity. Second, in order to prevent the contact of molten ash directly with the HTHX tubes, alloy surface temperature was limited to $<1925^{\circ} \mathrm{F}\left(1052^{\circ} \mathrm{C}\right)$, and as a result, furnace temperature did not exceed $2720^{\circ} \mathrm{F}\left(1494^{\circ} \mathrm{C}\right)$. Finally, no attempt was made to routinely sootblow the CAH and air preheater surfaces in order to develop ash deposits for characterization, resulting in HTHX inlet process air temperatures $300^{\circ} \mathrm{F}\left(167^{\circ} \mathrm{C}\right)$ lower than those observed during tests evaluating the earlier HTHX configuration. Therefore, based on previous HTHX tests and the data generated during the coal-biomass cofiring tests, the EERC is confident that process air temperatures of $>1700^{\circ} \mathrm{F}\left(>927^{\circ} \mathrm{C}\right)$ can be achieved and maintained if the entire surface of the HTHX is exposed to furnace conditions, the alloy tube surface temperature limit is raised to $<2000^{\circ} \mathrm{F}\left(1094^{\circ} \mathrm{C}\right)$, and routine sootblowing of $\mathrm{CAH}$ and air preheat surfaces is employed.

\section{SUBTASK 1.2 - CONTROLLED SPONTANEOUS REACTOR FOR IMPROVING BIOMASS FEEDING FOR COMBUSTION AND GASIFICATION}

\section{Introduction}

Biomass and other renewables such as municipal sewage sludge, municipal solid waste (MSW), wood waste, agricultural residue, animal waste, and dedicated energy crops (e.g., hybrid poplar or switchgrass) are potential low-cost feedstocks for heat, power, and chemical (e.g., ethanol) production. However, their high and variable moisture contents and the fibrous and often heterogeneous nature of these materials may limit their potential for widespread utilization. Coarse materials (greater than 1 in.) can be and are fired in stoker feed and bubbling-bed systems, usually small industrial-sized systems. Circulating fluidized-bed systems, large industrial and small utility-sized systems, require additional size reduction (typically $-6.4 \mathrm{~mm}$ [ $-1 / 4$ in.]). Use of biomass in large industrial and utility-sized conventional suspension-fired systems or advanced entrained-flow gasification systems requires a significant reduction of the feed material for ease of feed and for complete combustion. As a comparison, coal is typically reduced to $80 \%$ less than 200 mesh (0.003 in.). Because of its decreased density and increased reactivity, biomass can be sized somewhat larger compared to coal for a suspension-fired system. Designing a conversion system that is capable of handling a wide variety of these opportunity 
fuels is especially challenging, and the challenge multiplies considerably when it is intended to deliver one of these fuels into a pressurized atmosphere.

The EERC believes that pretreating the biomass or renewables at temperature conditions higher than what would be required for just drying will produce an enhanced fuel. The treated fuel will have a reduced propensity for moisture reabsorption, have a more consistent heat content, be easier to size-reduce by conventional coal-processing equipment, and have enhanced flow and conveyance properties, whether feeding in either a dry or slurry form. With respect to suspension-fired systems, the biomass or renewable fuel can be converted to a form that is more easily pulverized in conventional bowl mills, which would allow easier blending with coal on existing systems. Both dry and slurry forms of the enhanced biomass will have application for the advanced entrained-flow gasifiers such as the Global Energy E-Gas and the Texaco systems. These systems are presently slurry-fed, and maintaining this capability would reduce the complexities of having dual (dry and slurry) feed systems. Since DOE and a commercial sponsor are presently funding efforts to develop a dry feed system for these pressurized $(+2.1 \mathrm{MPa}$ [+300 psi]) gasifiers, it is suspected that the treated enhanced biomass, relative to the original material, will be much more easily pneumatically conveyed at higher solid-gas mass ratios, will flow more easily from hoppers through discharge points, and will require a smaller feed system for an equivalent capacity. It is also possible that high-pressure extrusion-type feeders originally developed for coal may be applicable to the enhanced biomass.

The CSR, developed and patented (1) at the EERC, presents opportunities to costeffectively produce enhanced biomass or renewable fuels. The CSR, originally designed for upgrading lignitic and subbituminous coals for fluid-bed systems (2), is an atmospheric pressure fluidized-bed system that uses a unique distributor plate design to impart a controlled and varied velocity profile across the bed to effectively size-segregate the treated fuel. While the CSR has the capability to operate as a stand-alone drying or fuel-conditioning facility, it could be more effectively integrated into an existing combustion or gasification system by using lowtemperature $\left(149^{\circ} \mathrm{C}\left[300^{\circ} \mathrm{F}\right]\right)$ stack gas or some other low-grade source of heat readily available as its primary heat source in the fluidizing gas. When additional heat is required within the fluidized bed, a small percentage of the bed can be allowed to combust by controlling the solid and gas residence times and the oxygen content of the fluidizing gas.

The general advantages of the CSR are its high throughput for a small footprint, simplicity of operation and control, and adaptability to a wide range of feedstock particle sizes. The CSR has the inherent ability to control the physical and chemical properties of the product, including size, grindability, and moisture; volatile matter; and heat content by selecting the appropriate combination of design and operating parameters. Further, the CSR provides the opportunity to function as a classifier by separating matter extraneous to the feed (e.g., partings in coal and tramp metal in wood waste) or discrete mineral fractions (e.g., pyrite in coal) that are liberated by thermal fracturing during drying. Because of the high solids inventory in the fluidized bed, the CSR is much more forgiving of upsets in fuel feeding than the process to which it is dedicated. Depending upon the CSR conditions of operation and the feed material, a low-Btu gas can be produced mostly by devolatilization of the feed material for beneficial use elsewhere in the process or in support of the process. 


\section{Experimental}

\section{Initial Experimental Configuration}

The initial conceptual design for this concept used data from mass and energy balances generated from earlier work performed on an entrained carbonizer (2). A 20-cm (8-in.) pilotscale system was constructed to generate the data required to verify the present concept. In the original pilot unit, coal was fed via a screw feeder into the bottom of the bed. Fluidizing gas was made up from a combination of air and nitrogen. Air flow was varied to obtain the correct air-tofuel ratio, and the addition of nitrogen allowed variations in fluidizing velocity. In a commercial system, flue gas would be used instead of nitrogen to produce the desired fluidizing velocity and limit the available oxygen. The product coal rising to the top of the bed flowed by gravity into a sealed collection barrel. Fine coal particles, moisture, and volatile gases from the treated coal were carried up out of the system, sampled, and combusted in an existing pc-fired furnace.

Some modifications were made to the CSR pilot plant upon completion of the first set of coal tests. An electric preheater was added to increase operating flexibility by allowing for control of the inlet temperature. A conical section was inserted in the bottom portion of the CSR to reduce the cross-sectional area at the distributor plate level, thereby increasing the superficial gas velocity at the bottom of the bed by a factor of four. These modifications permitted operation with larger coal particles and to better simulate the geometry of a full-scale CSR system. The coal feeder was moved toward the top of the bed, approximately $66 \mathrm{~cm}$ (26 in.) above the distributor plate, to reduce feed problems. The amount of insulation around the reactor was increased to reduce excessive heat loss.

\section{Selection of Biomass Raw Material}

Shredded tree trimmings, considered a subset of urban wood waste (UWW), were selected as a commonly available biomass material. This material was felt to be representative of a wide range of biomass materials available and was readily available for this testing. The UWW used in this testing was shredded at the curbside by a municipal-owned and -operated trailer-type shredder and piled at a municipal dump site. EERC personnel then hammer-milled the UWW through a screen with 1-in.-diameter openings. This milled UWW was used as feedstock for the CSR. Because of the fibrous nature of the UWW, the milled UWW had, in general, a wide size distribution and a very large length-to-diameter ratio, which is typical of many other biomass materials. The approximate bulk density of the UWW was $176 \mathrm{~kg} / \mathrm{m}^{3}\left(11 \mathrm{lb} / \mathrm{ft}^{3}\right)$.

\section{Biomass In-Feed System}

The milled UWW was fed into the CSR with the same conventional screw feeder as used for the previous coal tests, at a level approximately $66 \mathrm{~cm}$ (26 in.) above the bottom of the reactor side of the CSR, having a nominal 20-cm (8-in.) diameter. Some classic biomass feed system issues were encountered, such as bridging in the feeder hopper and feed screw lodging. These problems were somewhat due to the small scale of the test equipment and the inability to maintain a negative pressure in the reactor during the early tests as discussed in more detail later. 
The feed screw end location, relative to the inner surface of the CSR reactor section, was varied as the test program proceeded. The feed screw end was initially located about $2.5 \mathrm{~cm}$ (1 in.) into the CSR section as was done with coal testing. The screw end was moved back from the inner surface of the CSR in later tests in order to create a plug between the end of the feed screw and the CSR wall. Moving the feed screw end away from the inner surface of the CSR section did induce the milled UWW to form a plug, but the plug was not sufficient to create a gastight boundary between the in-feed system and the CSR. The in-feed system was mechanically separated from the CSR when not feeding biomass material during the final test, which prevented hot gas from entering into the feeder and potentially igniting the raw fuel if there was a positive pressure excursion inside the reactor. Under normal operation, when operating at a slightly negative pressure in the reactor, sealing the feed system prevented unwanted air from entering in through the feeder and causing uncontrolled combustion of the fuel in the reactor. These feeder design issues can be readily addressed in the initial design phase of a commercial system.

\section{Fluidizing Gas}

It is anticipated that existing plant flue gas would be used as the primary fluidizing gas component in a commercial CSR for its heat content and reduced oxygen content. A low fluidizing gas oxygen content is required to limit and/or eliminate combustion in the CSR. In this testing, EERC house nitrogen was used as a substitute for flue gas and blended with EERC house compressed air to create the CSR fluidizing gas. This blended gas was then heated with electric resistance heaters prior to introduction to the CSR. For a commercial system, recirculated CSR flue gas could also additionally decrease the oxygen content if required for operational purposes to control consumption of the product by any unnecessary combustion while maintaining the proper fluidizing velocity.

\section{CSR Distributor Plate Design}

The original CSR distributor was slightly modified in order to fluidize the milled UWW, yet the design and operational concepts of the original patented CSR were retained. The distributor, as used for the milled UWW in the CSR, was to induce the bed to behave as a spouting bed, where the solids are rapidly driven up the core of the bed by the fluidizing gas and then recirculated down the side walls of the CSR reactor by gravity. However, because of the wide size distribution and large length-to-diameter ratio of the milled UWW, fuel bridging occurred in the reactor. These fuel bridges were of a tenacious nature with intertwined and interlocked stands of the UWW. With an increase in operational size, it is less likely that fuel bridging will be as significant an issue in a full-scale commercial system. The distributor plate design in a full-scale commercial system is expected to more closely resemble the patented CSR design, taking into consideration the required fluidizing velocities required for good operation.

\section{CSR Agitator}

A significant design change was the addition of an in-bed agitator to break up the interlocking fuel bridges and assist with proper mixing of the milled UWW. Continuous mixing of the solids ensures a consistent solids-to-fluidizing gas contact area and may allow some 
fracturing of the milled UWW into pieces with a smaller length-to-diameter ratio. This fracturing enhances the transporting properties of the processed milled UWW. Mechanical agitation of the milled UWW also allows the use of a lower gas fluidizing velocity, which results in a longer residence time of the smaller particles that would otherwise be ejected from the CSR. The agitator consisted of a vertical shaft connected to a variable-speed motor that was mounted to the top of the CSR section with horizontal fingers welded to the vertical shaft, beginning immediately above the distributor and ending just above the milled UWW in-feed screw opening. The installed agitator worked well, and it is anticipated that the power requirements in an operating commercial system would be minimal if mechanical agitation is required.

\section{Biomass Product Drain System}

The biomass product drain system was slightly modified from the original CSR configuration, which was a simple outlet flexible pipe connection where the solids flowed by gravity to a collection barrel. Initially, the final portion of the outlet pipe was placed in a more vertical orientation. Gravity was not enough of a driving force to bring the solids down the short length of 45 degree outlet pipe before entering the vertical leg. A mechanical scraper was installed in the outlet pipe in an effort to drag the solids to the barrel. Only very minor amounts of solids exited this out-feed system during testing, probably due to the outlet being located too high in the freeboard section of the CSR. The primary velocity component of the smaller solid particles is in the upward direction in this region, which would require a radical direction change in order to utilize the existing exit scheme. Removing product might not be as much of an issue in a larger full-scale system. Either a mechanical-type system, such as an extractive in-bed auger, could be used to drain product material, or with proper design, all of the product could be allowed to elutriate out of the reactor into either a collection cyclone or directly into the adjacent process.

\section{CSR Outlet to Furnace}

The CSR outlet was connected to a tertiary air inlet on the EERC combustion test furnace (CTF). The connecting pipe was enlarged to a 7.6-cm (3-in.) pipe from the original 5.1-cm (2in.) pipe to help maintain a negative pressure within the CSR reactor. Negative pressure in the CSR reactor was achieved by running the induced-draft blower on the CTF at a higher negative pressure than is normal for that system. It was noted that with each test the ability to maintain a negative pressure within the CSR became progressively worse. Prior to the last test, a tarlike blockage at the refractory entrance into the CTF was removed, subsequently allowing for better pressure control in the CSR reactor.

\section{Data Acquisition}

The fluidizing gas flow rate was manually controlled, and the inlet oxygen content was calculated from measurements of the temperature, pressure, and flow rates of the fluidizing gas (nitrogen and air blend). The milled UWW feed rate was calculated from feed times and weights. Available electronic signals were wired into the existing CTF data acquistion system.

Temperatures were measured in four locations in the CSR reactor and in two locations in the CSR downcomer. CSR bed differential pressure was measured, as well as static pressure in the 
downcomer. Product gases were sampled from a port located in the downcomer and routed to a portable rack of gas analyzers (oxygen, carbon dioxide, carbon monoxide, oxides of nitrogen, and sulfur dioxide) and to a hydrocarbon analyzer associated with another EERC test system. All gas analyzers were tied into the gas analysis system.

\section{Test Conditions}

An initial test matrix was identified based upon review of previous CSR testing performed with lignite and subbituminous fuels. Additionally, cold-flow testing was performed with the UWW to verify its actual minimum fluidization velocity. Cold-flow testing served two purposes. It verified that the fuel feed system would perform adequately and defined the type of distributor plate that would perform adequately with a biomass fuel. This effort was far more substantial than originally anticipated, but was invaluable for the successful hot-flow testing. The major hurdle was how tenacious the UWW was in binding together in clumps and causing the bed to defluidize. This is a tendency that is expected to occur with any long-fiber biomass material. As previously discussed, a combination of a spouting-bed distributor plate and an in-bed stirring agitator overcame this problem. The proposed test matrix is shown in Table 5. A summary of test conditions performed is shown in Table 6.

\section{Results and Discussion}

The first two tests were on pure nitrogen. This allowed checkout of the feed system at hot test conditions and demonstrated that a highly reactive biomass material could be safely dried in a fluidized-bed system. Some modifications were required after these tests to allow for safer operation with an oxygen-blended fluidizing gas. The most significant modification was a changeover to spouted-bed operation.

Tests 3-5 served as building blocks to establish the required procedures to feed a reactive biomass material into a hot fluidizing gas. Within the constrained limits of this test matrix, it was established that a limited oxygen content was required to limit the amount of reaction in the bed. A final modification before Test 6 was the addition of an isolation plate that isolated the feed system from the CSR reactor when not feeding.

During Test CSR006, the CSR was operated with an inlet fluidizing gas temperature of approximately $260^{\circ} \mathrm{C}\left(500^{\circ} \mathrm{F}\right)$, inlet oxygen contents of $1.3 \%$ and $2 \%$, and a gas fluidization rate of approximately $127 \mathrm{~m}^{3} / \mathrm{hr}$ (75 scfm). CSR temperatures are shown in Figure 16 . The feeder was operated to ensure a reasonable bed level for the duration of the test, and the bed differential pressure was kept above approximately $2.5 \mathrm{~cm}$ (1 in.) of water column at all times. When operating, the feeder supplied the CSR reactor at an average feed rate of $67 \mathrm{~kg} / \mathrm{hr}(148 \mathrm{lb} / \mathrm{hr})$ (51.4 lb/hr per $\mathrm{ft}^{2}$ of CSR cross section). Total feed time was $19 \mathrm{~min}$ in a total testing time of 106 min (18\%). CSR gas concentrations are shown in Figure 17. Downcomer gas analysis indicated a $20 \%-23 \%$ reduction in oxygen content as compared to the fluidizing gas inlet oxygen content. Large amounts of carbon monoxide (maximum of 2800 ppm) were measured, and the carbon dioxide content seemed to slowly but continuously increase. No hydrocarbons 
Table 5. Proposed Test Matrix

\begin{tabular}{lcccc}
\hline Test Number & $\begin{array}{c}\text { Feed Rate, } \\
\text { kg/hr (lb/hr) }\end{array}$ & $\begin{array}{c}\text { Total Gas Flow, } \\
\text { L/min (scfm) }\end{array}$ & $\begin{array}{c}\text { Temperature In, } \\
{ }^{\circ} \mathrm{C}\left({ }^{\circ} \mathrm{F}\right)\end{array}$ & $\begin{array}{c}\text { Oxygen } \\
\text { Content, } \\
\%\end{array}$ \\
\hline 1 & $23(50)$ & $2124(75)$ & $149(300)$ & 0 \\
2 & $23(50)$ & $2124(75)$ & $260(500)$ & 0 \\
3 & $23(50)$ & $2124(75)$ & $149(300)$ & 3 \\
4 & $23(50)$ & $2124(75)$ & $260(500)$ & 3 \\
5 & $23(50)$ & $2124(75)$ & $149(300)$ & 6 \\
6 & $23(50)$ & $2124(75)$ & $260(500)$ & 6 \\
\hline
\end{tabular}

Table 6. Summary of Test Conditions

\begin{tabular}{lcccc}
\hline Test Number & $\begin{array}{c}\text { Average Feed Rate, } \\
\mathrm{kg} / \mathrm{hr}(\mathrm{lb} / \mathrm{hr})\end{array}$ & $\begin{array}{c}\text { Average Total } \\
\text { Gas Flow, } \\
\text { L/min (scfm) }\end{array}$ & $\begin{array}{c}\text { Inlet } \\
\text { Temperature, } \\
{ }^{\circ} \mathrm{C}\left({ }^{\circ} \mathrm{F}\right)\end{array}$ & $\begin{array}{c}\text { Inlet Oxygen } \\
\text { Content, \% }\end{array}$ \\
\hline CSR001 & $23(50)$ & $1611(57)$ & $149(300)$ & 0 \\
CSR002 & $23(50)$ & $1940(69)$ & $260(500)$ & 0 \\
CSR003* & $23(50)$ & $2141(76)$ & $149(300)$ & 2.7 \\
CSR004* & $15(33)$ & $2112(75)$ & $260(500)$ & 3.1 \\
CSR005A* & $23(50)$ & $2124(75)$ & $260(500)$ & 2.8 \\
CSR005B* & $31(68)$ & $2124(75)$ & $260(500)$ & 1.5 \\
CSR005C* & $31(68)$ & $2124(75)$ & $260(500)$ & 2.3 \\
CSR006A* $^{*}$ & $12(26.5)$ & $2124(75)$ & $260(500)$ & 1.3 \\
CSR006B* & $12(26.5)$ & $2124(75)$ & $260(500)$ & 2 \\
\hline
\end{tabular}

* Reactor stirring agitation was used.

were detected in the downcomer gas, but these may have been stripped from the analyzer gas stream as part of the gas-conditioning process (water and dessicant impingers were used to protect the analyzing equipment). A comparison of the unprocessed milled UWW to the processed UWW remaining in the CSR reactor shows that moisture was reduced $97 \%$, while the heating value was increased 63\% (as-received basis). The processed UWW seems to have very favorable characteristics in terms of its ability to be directly fed into a solids fuel furnace. Proximate and ultimate analyses were conducted on unprocessed milled UWW and the CSR- 


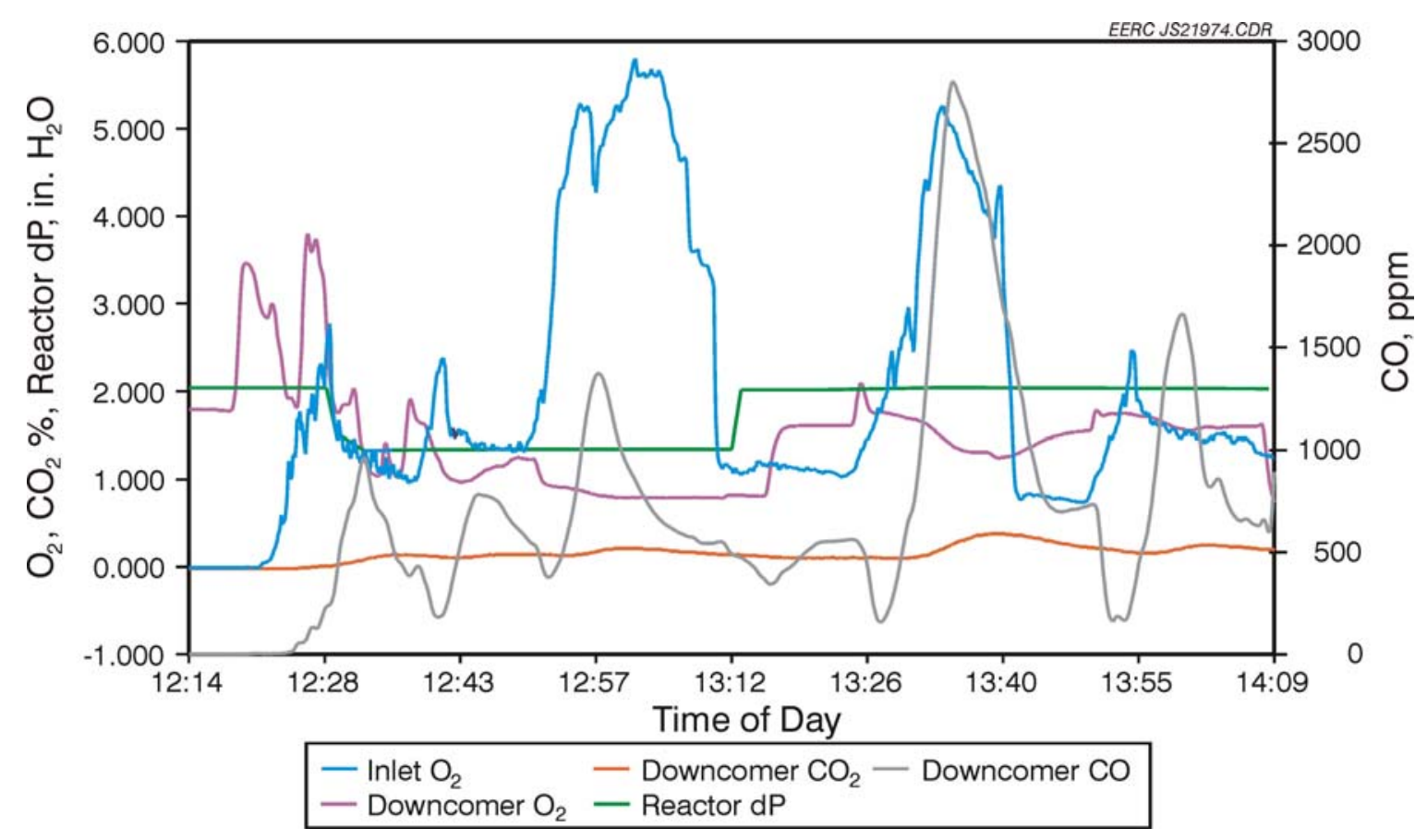

Figure 16. CSR temperatures for Test 6.

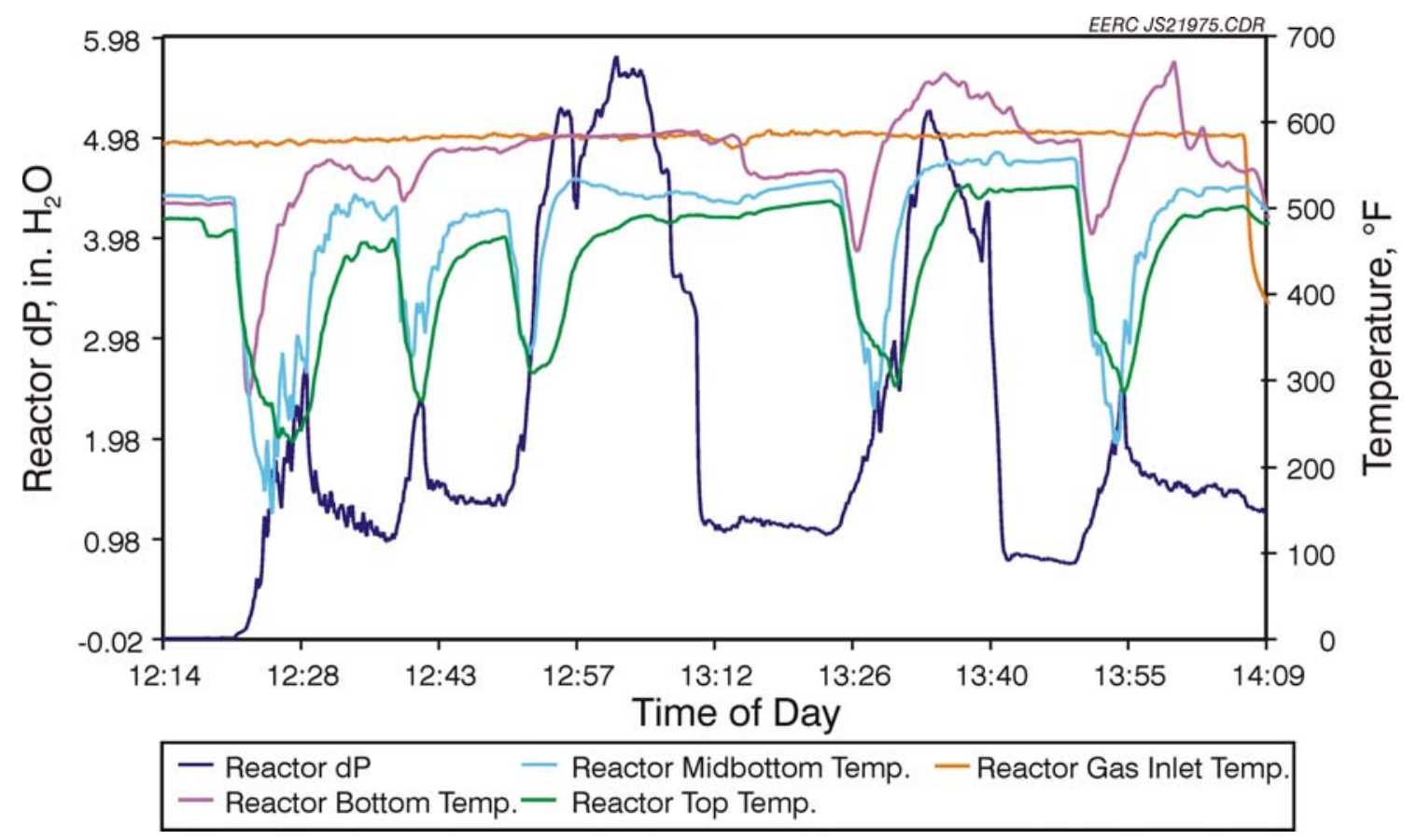

Figure 17. CSR gas concentrations for Test 6. 
processed UWW, and a sieve analysis was conducted on unprocessed milled UWW and residue captured in the downcomer in the final test.

\section{Simulated Rod Mill Size Reduction Testing}

A test apparatus and method were developed at the EERC to allow qualitative and quantitative comparison of the ease in which the raw and CSR-treated UWW are reduced by impact milling. The apparatus consisted of a heavy-walled cylindrical SS vessel, 18-cm (7.25in.) and 17.8-cm (7-in.) internal length. Ten 1.9-cm (0.75-in.)-diameter rods, with a length of $16.2 \mathrm{~cm}$ (6.375 in.), were used as the grinding media. The total weight of the ten grinding rods was

$6.45 \mathrm{~kg}$ (14.2 lb). An approximately 100-g charge of raw or treated biomass was used in each milling test. The mill was rotated at a speed of $87 \mathrm{rpm}$ for $15 \mathrm{~min}$ in each test. The postmilling material was recovered for comparison and analysis. A batch type of test was employed over a continuous test, such as feeding to hammer or knife mill. Consistent, uninterrupted feeding was considered too difficult to obtain on the bench-scale level.

Milling tests were performed on the nominal $-2.5 \mathrm{~cm}$ (-1-in.) raw UWW plus product from CSR Tests 003, 005, and 006. Figure 18 shows unprocessed, $-2.5 \mathrm{~cm}(-1$-in.) hammer mill, CSR processed, and milled CSR processed UWW, respectively. Only qualitative comparison of the milled products was performed. The 15-min tumble time was sufficient to transform the CSR Test 006 product into a talcum powderlike consistency. No visible wood fibers were in the milled material. This is in stark contrast to the raw wood and even dried wood from CSR 003. Modest observable size reduction was obtained during milling of the raw wood waste at approximately $36 \mathrm{wt} \%$ moisture. The CSR 003 material at less than $0.7 \mathrm{wt} \%$ moisture was
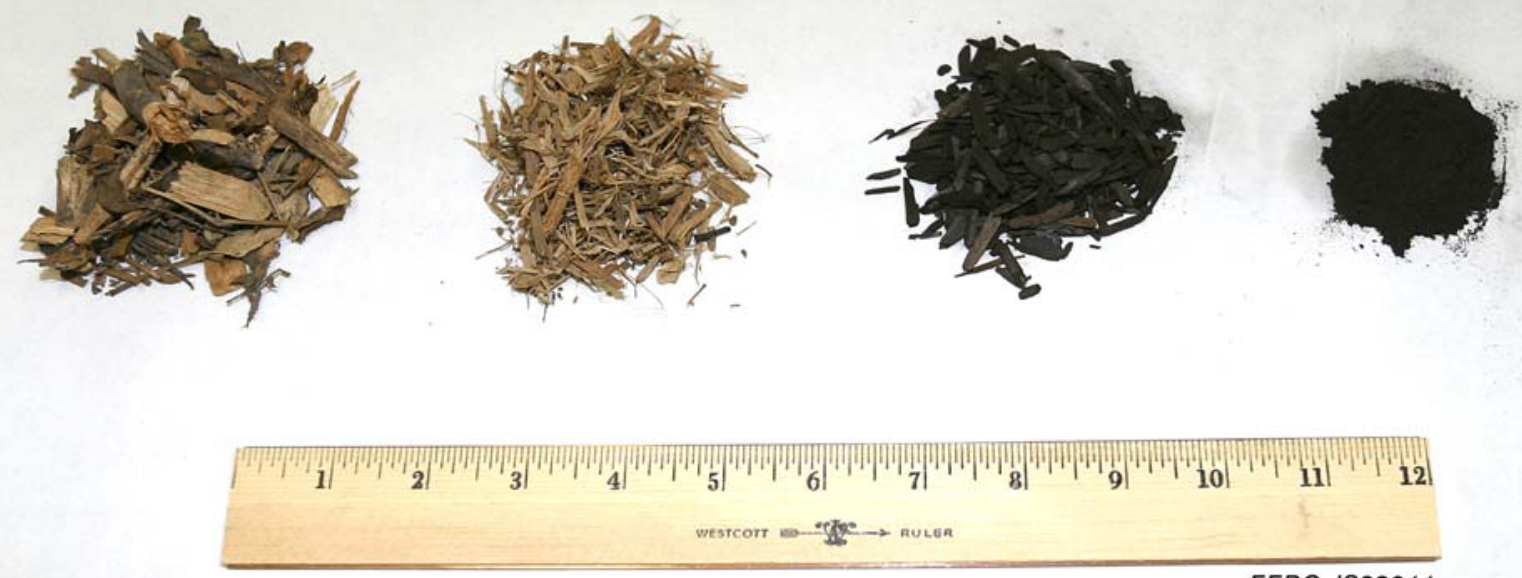

EERC JS22011

Figure 18. Comparison of milling tests performed on the raw unprocessed UWW ( -1 in.), as compared to the CSR processed UWW obtained from Test 6. 
somewhat further reduced in overall size relative to the raw wood waste. The CSR 005 product at less than $0.2 \mathrm{wt} \%$ moisture was considerably reduced in size, with significant fines produced during milling. Although there was still much fibrous or splinter-shaped material in the milled CSR 005 product, approximately $75 \mathrm{wt} \%$ appeared to be less than $0.6 \mathrm{~cm}(1 / 4 \mathrm{in}$.) in length and less than $1.5 \mathrm{~mm}$ in thickness. For the CSR 003 milled product, approximately $75 \mathrm{wt} \%$ appeared greater than $0.6 \mathrm{~cm}(1 / 4 \mathrm{in}$.) in length with a thickness of $2-3 \mathrm{~mm}$.

\section{Rheological Evaluation of Char-Water Slurries}

A number of water-based slurries were prepared using the CSR 006 product in $20 \mathrm{wt} \%$ blends with coal and petroleum coke. Three slurries were prepared for rheological evaluation using the following primary fossil fuels: Belle Ayr subbituminous coal, Illinois No. 6 bituminous coal, and petroleum coke. The coals and petroleum coke had a nominal combustion grind consisting of $80 \%$ passing 200 mesh. The CSR 006 product from the milling tests (previously described) was used for slurry preparation. Water was added until the char-primary fuel slurry appeared to have flowability similar to that of coal-water slurry fuels traditionally prepared at the EERC. No attempt was made to optimize the rheology through particle-size adjustment, shearing, or use of additives.

A Haake rotational viscometer was used to determine viscosity as a function of shear rate over the range of $0-450 \mathrm{sec}^{-1}$ at both increasing and decreasing shear rate. The viscosity at $100 \mathrm{sec}^{-1}$, the shear rate at which the EERC has typically reported viscosity values for coal-water fuels, was also selected as the reporting basis for the char-based slurry fuels. At 100 $\mathrm{sec}^{-1}$, the viscosities for the three respective fuels (with CSR 006 char) were 385, 650, and 670 cP with associated solids loadings of 40.2, 50.4, and $52.2 \mathrm{wt} \%$. Although not tested, a char-water slurry with an approximately $31 \mathrm{wt} \%$ solids loading appeared to have similar consistency to the rheologically tested fuels.

In comparison to bituminous coal and petcoke slurries that are currently being fired in entrained-flow gasifiers operated at Wabash River (by Global Energy) and Tampa, the charbased slurries would have to improve their solids loadings by 10 or more wt\%. Biomass-based slurries with lower solids loadings than those currently used in these clean-coal facilities could be justified if they have an associated tipping fee (revenue to the utility) that would offset the processing (low-temperature pyrolysis) cost and the economic penalty associated with the higher moisture content of the fuel. Owing to its high friability, size reduction of the biomass char from a CSR-type system would appear to be more easily (and cost-effectively) achieved relative to the coal or petcoke. Further, this size reduction could be done in the wet rod or ball mills currently used to process the coal and petcoke for use in the entrained-flow gasifiers.

\section{Conclusions}

The CSR pilot-scale system was successfully used to physically and chemically alter biomass material, resulting in a fuel that is suitable for feeding into a coal combustion or gasification system operated at either atmospheric or pressurized conditions, with little or no feed system modifications required. 
Based upon the size reduction testing, the altered CSR biomass product should require very low power requirements for any additional size reduction. The resulting biomass product also has good potential for incorporation into a slurry form for feeding or transport.

While 2.5-cm (1-in.) material was the maximum size capable of being fed into the pilotscale system, a full-scale commercial system would be expected, with proper design, to easily accommodate larger material up to at least $7.6 \mathrm{~cm}$ (3 in.) in size. Larger-sized material would require either longer residence times that could be handled by increasing the operational bed depth or, possibly, by operation at higher temperatures or at increased oxygen content of the fluidizing gas.

Successful operation of the pilot-scale system required limiting the inlet oxygen content for the fluidizing gas to less than $2 \%$. It is expected that operation with higher inlet oxygen concentrations will be possible with a full-scale commercial system. When a flue gas is used from an adjacent system for the supply of hot fluidizing gas for the CSR, the inlet oxygen concentration can be reduced, if required, by recirculating a portion of the CSR product gas back to the CSR. A controlled air bleed into the CSR would allow an increase of oxygen if required.

A spouting-bed distributor plate along with mechanical agitation was required to maintain fluidization of the biomass within the CSR and to prevent the biomass feed material from intertwining into an immovable mass and eventually into a plug of material. A more conventional CSR distribution system should be usable in a larger-scale system. If mechanical agitation is required in a larger-scale system, it could be accomplished with minimal power requirements. Removal of solid product from the system needs to be investigated at a larger scale, but it is not expected to be a significant issue in a full-scale system.

Overall, it has been demonstrated that the CSR concept is highly suited for the purpose of modifying biomass material for ease of feed into existing commercial energy systems.

\section{SUBTASK 1.3 - BIOLOGICAL HYDROGEN PRODUCTION}

\section{Introduction}

Biological production of hydrogen is possible in bacteria, blue-green algae (cynanobacteria), and green algae through a number of enzyme systems such as the nitrogenase, photosystems, enzymes of the pentose phosphate pathway, and many other oxidative-reduction enzymes (3). One key to low-cost hydrogen is the utilization of cheap sources of energy for the process. Sunlight-fueled processes may be the ultimate source of hydrogen, but currently the photo-driven systems are not sufficiently understood to allow for utilization of this source. Anaerobic bacteria frequently produce hydrogen, as they generate a large amount of electrons and have a paucity of suitable electron acceptors. When these anaerobes have appropriate hydrogenase enzymes, hydrogen evolves. Limitations on evolution of hydrogen from these anaerobes is often that high concentrations of hydrogen impact the thermodynamic efficiency, preventing further metabolism (4). 
Recent research has shown that the thermophilic anaerobe Thermotoga neapolitana can produce about 28 mol\% hydrogen in the gas phase, with the remainder carbon dioxide, from carbohydrates (5). This bacterium was isolated from a deep ocean thermal vent and is a heterotrophic sulfur-reducing microbe (6). In the absence of sulfur, and with sufficient carbohydrate, significant amounts of hydrogen are evolved. T. neapolitana does not appear to be inhibited by hydrogen. This microbe can ferment many monosaccharides and polysaccharides such as cellulose. As a thermophile, it has an optimum growth temperature at $77^{\circ} \mathrm{C}$, resulting in fairly rapid rates of metabolism. Calculations made by researchers at Oak Ridge National Laboratory suggest that by coupling a $T$. neapolitana bioreactor to a fuel cell, efficiencies of energy production from carbohydrates may approach 98\% (7).

\section{Experimental}

Two cultures of Thermotoga spp. were obtained and evaluated. Growth and hydrogen production of each culture was tested in batch cultures. Following that, a series of experimental designs was planned to evaluate the effect of key variables on hydrogen production in these microbes. These variables are $\mathrm{pH}$, temperature, and feedstock, and the values for these tests will range, respectively, from 7 to $9,50^{\circ}$ to $90^{\circ} \mathrm{C}$, and with glucose, soluble starch, cellulose, and other carbohydrates. These batch tests were performed under axenic conditions, in serum bottles with a headspace of nitrogen. Growth was to be evaluated by culture turbidity, and hydrogen production will be assessed by injecting a sample from the headspace in a gas chromatograph with thermal conductivity detection. These data were expected to provide baseline data for comparison of the different cultures.

Strain improvement is a rather simple method that can sometimes provide large dividends. The two cultures were subjected to repeated transfers in batch culture using cellulose, as the sole feedstock. Mutation was planned in an attempt to deregulate cellulose enzymes or otherwise improve catabolism of cellulose. Mutagenesis was to be performed with chemical mutagens (8). Mutagen-treated cultures were subjected to further serial transfers with cellulose as the feedstock, then growth and hydrogen production were to be evaluated. If significant improvements are noted, the strain isolation and further improvement will be attempted.

\section{Growth Media}

The growth media used was that of van Ooteghem et al. (5) modified American Type Culture Collection Media 1977 recommended for Thermotoga elfeii. composed of the following:

$\begin{array}{ll}\mathrm{NH}_{4} \mathrm{Cl} & 1.0 \mathrm{~g} \\ \mathrm{~K}_{2} \mathrm{HPO}_{4} & 0.3 \mathrm{~g} \\ \mathrm{KH}_{2} \mathrm{PO}_{4} & 0.3 \mathrm{~g} \\ \mathrm{MgCl}_{2} \cdot 6 \mathrm{H}_{2} \mathrm{O} & 0.2 \mathrm{~g} \\ \mathrm{CaCl}_{2} \cdot 2 \mathrm{H}_{2} \mathrm{O} & 1.0 \mathrm{~g} \\ \mathrm{NaCl} & 10.0 \mathrm{~g} \\ \mathrm{KCl} & 0.1 \mathrm{~g} \\ \text { Cysteine-HCl } & 1.0 \mathrm{~g}\end{array}$


Yeast Extract

Trypticase

Vitamin Solution

Trace Element Solution

$\mathrm{dH}_{2} \mathrm{O}$
$2.0 \mathrm{~g}$

$2.0 \mathrm{~g}$

$10.0 \mathrm{~mL}$

$10.0 \mathrm{~mL}$

$1 \mathrm{~L}$

Adjust $\mathrm{pH}$ to 8.5 at $20^{\circ} \mathrm{C}$ with $\mathrm{NaOH}$. Carbon added at $5 \mathrm{~g} / \mathrm{L}$.

Vitamin Solution (DSM Medium 141):

$\begin{array}{ll}\text { Biotin } & 2.0 \mathrm{mg} \\ \text { Folic Acid } & 2.0 \mathrm{mg} \\ \text { Pyridoxine-HCl } & 10.0 \mathrm{mg} \\ \text { Thiamine-HCl } & 5.0 \mathrm{mg} \\ \text { Riboflavin } & 5.0 \mathrm{mg} \\ \text { Nicotinic Acid } & 5.0 \mathrm{mg} \\ \text { D-Ca Pantothenate } & 5.0 \mathrm{mg} \\ \text { Vitamin B } \text { (cyanocobalamin) }_{\text {p-Aminobenzoic Acid }} & 0.1 \mathrm{mg} \\ \text { Lipoic Acid (thioctic acid) } & 5.0 \mathrm{mg} \\ \mathrm{dH}_{2} \mathrm{O} & 5.0 \mathrm{mg}\end{array}$

Filter, sterilize, and store refrigerated in the dark.

Trace Element Solution (DSM Medium 141):

\begin{tabular}{|c|c|}
\hline Nitrilotriacetic acid & $1.5 \mathrm{~g}$ \\
\hline $\mathrm{MgSO}_{4} \cdot 7 \mathrm{H}_{2} \mathrm{O}$ & $3.0 \mathrm{~g}$ \\
\hline $\mathrm{MnSO}_{4} \cdot 2 \mathrm{H}_{2} \mathrm{O}$ & $0.5 \mathrm{~g}$ \\
\hline $\mathrm{NaCl}$ & $1.0 \mathrm{~g}$ \\
\hline $\mathrm{FeSO}_{4} \cdot 7 \mathrm{H}_{2} \mathrm{O}$ & $0.1 \mathrm{~g}$ \\
\hline $\mathrm{CoCl}_{2} \cdot 6 \mathrm{H}_{2} \mathrm{O}$ & $0.15 \mathrm{~g}$ \\
\hline $\mathrm{CaCl}_{2} \cdot 2 \mathrm{H}_{2} \mathrm{O}$ & $0.1 \mathrm{~g}$ \\
\hline $\mathrm{ZnSO}_{4} \cdot 7 \mathrm{H}_{2} \mathrm{O}$ & $0.18 \mathrm{~g}$ \\
\hline $\mathrm{CuSO}_{4} \cdot 5 \mathrm{H}_{2} \mathrm{O}$ & $0.01 \mathrm{~g}$ \\
\hline $\mathrm{KAl}\left(\mathrm{SO}_{4}\right)_{2} \cdot 12 \mathrm{H}_{2} \mathrm{O}$ & $0.02 \mathrm{~g}$ \\
\hline $\mathrm{H}_{3} \mathrm{BO}_{3}$ & $0.01 \mathrm{~g}$ \\
\hline $\mathrm{NiCl}_{2} \cdot 6 \mathrm{H}_{2} \mathrm{O}$ & $0.025 \mathrm{~g}$ \\
\hline $\mathrm{Na}_{2} \mathrm{SeO}_{3} \cdot 5 \mathrm{H}_{2} \mathrm{O}$ & $0.3 \mathrm{mg}$ \\
\hline $\mathrm{dH}_{2} \mathrm{O}$ & $1 \mathrm{~L}$ \\
\hline
\end{tabular}

Dissolve nitrilotriacetic acid, adjust $\mathrm{pH}$ to 6.5 with $\mathrm{KOH}$, and then add others. Store refrigerated. 
Alternate Medium (9):

$\begin{array}{ll}\mathrm{NaCl} & 20 \mathrm{~g} \\ \mathrm{KCl} & 0.335 \mathrm{~g} \\ \mathrm{MgCl}_{2} \cdot 6 \mathrm{H}_{2} \mathrm{O} & 2.75 \mathrm{~g} \\ \mathrm{MgSO}_{4} \cdot 7 \mathrm{H}_{2} \mathrm{O} & 3.45 \mathrm{~g} \\ \mathrm{NH}_{4} \mathrm{Cl} & 0.25 \mathrm{~g} \\ \mathrm{CaCl}_{2} \cdot 2 \mathrm{H}_{2} \mathrm{O} & 0.14 \mathrm{~g} \\ \mathrm{~K}_{2} \mathrm{HPO}_{4} & 0.14 \mathrm{~g} \\ \mathrm{Glucose} & 5.0 \mathrm{~g} \\ \text { Yeast Extract } & 0.5 \mathrm{~g} \\ \text { PIPES } & 6.0 \mathrm{~g} \\ \text { Cysteine-HCl } & 0.5 \mathrm{~g} \\ \text { Resazurin } & 0.001 \mathrm{~g} \\ \text { Trace Element Solution } & 1 \mathrm{~mL} \\ \text { Vitamin Solution } & 1 \mathrm{~mL} \\ \text { dH } & \mathrm{O} \\ \end{array}$

pH 7.5 with $\mathrm{NaOH}$

Trace Element Solution:

\begin{tabular}{|c|c|}
\hline Nitrilotriacetic acid & $1.5 \mathrm{~g}$ \\
\hline $\mathrm{MgSO}_{4} \cdot 7 \mathrm{H}_{2} \mathrm{O}$ & $3.0 \mathrm{~g}$ \\
\hline $\mathrm{MnSO}_{4} \cdot 2 \mathrm{H}_{2} \mathrm{O}$ & $0.5 \mathrm{~g}$ \\
\hline $\mathrm{NaCl}$ & $1.0 \mathrm{~g}$ \\
\hline$\left(\mathrm{NH}_{4}\right)_{6} \mathrm{Mo}_{7} \mathrm{O}_{24} \cdot 4 \mathrm{H}_{2} \mathrm{O}$ & 0.37 \\
\hline $\mathrm{CoCl}_{2} \cdot 6 \mathrm{H}_{2} \mathrm{O}$ & $0.34 \mathrm{~g}$ \\
\hline $\mathrm{CaCl}_{2} \cdot 2 \mathrm{H}_{2} \mathrm{O}$ & $0.1 \mathrm{~g}$ \\
\hline $\mathrm{FeSO}_{4} \cdot 7 \mathrm{H}_{2} \mathrm{O}$ & $0.1 \mathrm{~g}$ \\
\hline $\mathrm{ZnSO}_{4} \cdot 7 \mathrm{H}_{2} \mathrm{O}$ & $0.32 \mathrm{~g}$ \\
\hline $\mathrm{NiSO}_{4} \cdot 6 \mathrm{H}_{2} \mathrm{O}$ & $0.21 \mathrm{~g}$ \\
\hline $\mathrm{CuSO}_{4} \cdot 5 \mathrm{H}_{2} \mathrm{O}$ & $0.004 \mathrm{~g}$ \\
\hline $\mathrm{KAl}\left(\mathrm{SO}_{4}\right)_{2} \cdot 12 \mathrm{H}_{2} \mathrm{O}$ & $0.033 \mathrm{~g}$ \\
\hline $\mathrm{H}_{3} \mathrm{BO}_{3}$ & $0.01 \mathrm{~g}$ \\
\hline $\mathrm{NaSeO}_{4} \cdot 5 \mathrm{H}_{2} \mathrm{O}$ & $0.2 \mathrm{~g}$ \\
\hline $\mathrm{dH}_{2} \mathrm{O}$ & $1 \mathrm{~L}$ \\
\hline
\end{tabular}

Vitamin Solution: (same as DSM 141 solution)

Biotin

Folic Acid

Pyridoxine-HCl

Thiamine-HCl

Riboflavin
$2.0 \mathrm{mg}$ $2.0 \mathrm{mg}$ $10.0 \mathrm{mg}$ $5.0 \mathrm{mg}$ $5.0 \mathrm{mg}$ 
Nicotinic Acid

D-Ca Pantothenate

Vitamin B $_{12}$ (cyanocobalamin)

p-Aminobenzoic acid

Lipoic Acid (thioctic acid)

$\mathrm{dH}_{2} \mathrm{O}$

Improved Childers et al. Medium

\begin{tabular}{|c|c|}
\hline $\mathrm{NaCl}$ & $20 \mathrm{~g}$ \\
\hline $\mathrm{KCl}$ & $2.0 \mathrm{~g}$ \\
\hline $\mathrm{MgSO}_{4} \cdot 7 \mathrm{H}_{2} \mathrm{O}$ & $0.05 \mathrm{~g}$ \\
\hline $\mathrm{NH}_{4} \mathrm{Cl}$ & $0.25 \mathrm{~g}$ \\
\hline $\mathrm{CaCl}_{2} \cdot 2 \mathrm{H}_{2} \mathrm{O}$ & $0.14 \mathrm{~g}$ \\
\hline $\mathrm{K}_{2} \mathrm{HPO}_{4}$ & $0.14 \mathrm{~g}$ \\
\hline Glucose & $5.0 \mathrm{~g}$ \\
\hline Yeast Extract & $0.5 \mathrm{~g}$ \\
\hline PIPES & $6.0 \mathrm{~g}$ \\
\hline Cysteine $\mathrm{HCl}$ & $0.5 \mathrm{~g}$ \\
\hline Resazurin & $0.001 \mathrm{~g}$ \\
\hline Trace Element Solution & $1 \mathrm{~mL}$ \\
\hline Vitamin Solution & $1 \mathrm{~mL}$ \\
\hline $\mathrm{dH}_{2} \mathrm{O}$ & $1 \mathrm{~L}$ \\
\hline
\end{tabular}

$5.0 \mathrm{mg}$

$5.0 \mathrm{mg}$

$0.1 \mathrm{mg}$

$5.0 \mathrm{mg}$

$5.0 \mathrm{mg}$

$1 \mathrm{~L}$

Adjust pH to 7.5 with $\mathrm{NaOH}$

Vitamin Solution: biotin $2 \mathrm{mg} / \mathrm{L}$

Trace element soln: $\mathrm{FeSO}_{4} \cdot 7 \mathrm{H}_{2} \mathrm{O} 7 \mathrm{mg} / \mathrm{mL}(0.7 \mathrm{~g} / 100 \mathrm{~mL}), \mathrm{Na}_{2} \mathrm{WO}_{4} \cdot 2 \mathrm{H}_{2} \mathrm{O} 0.3 \mathrm{mg} / \mathrm{mL}$ (0.03 g/100 mL).

\section{Preparation of Media}

The vitamin solution was prepared by dissolving each vitamin one at a time in distilled, deionized water, filter sterilizing and storage at $4^{\circ} \mathrm{C}$. The trace element solution was prepared by dissolving the nitrilotriacetic acid first, then adjusting the $\mathrm{pH}$ with $\mathrm{KOH}$ to ca. 6.5, and then adding the other metals. This solution was also stored at $4^{\circ} \mathrm{C}$.

The media was assembled in a larger Erlenmeyer flask, heated to boiling while gassing with oxygen-free nitrogen, and then dispensed into gassed vessels (either $50 \mathrm{~mL}$ in a 160-mL serum bottle or ca. $5 \mathrm{~mL}$ in a Bellco tube). The filled vessels were capped and sealed with butyl rubber septae and autoclave. 


\section{Storage of Cells}

Cells were grown to a high density. During the log growth phase, a 1-mL aliquot was aseptically added to sterile cryotubes to which $250 \mu \mathrm{L}$ of $80 \%$ sterile glycerol in water had been added. These tubes were stored at $-85^{\circ} \mathrm{C}$.

\section{General Procedures}

General methods follow the modified Hungate technique using syringes (9). Oxygen-free gases are used to flush media and vessels prior to inoculation. These gases are made oxygen-free by passing them through a heated $\left(350^{\circ}\right.$ to $\left.400^{\circ} \mathrm{C}\right)$ column containing copper windings. The gas exits the copper column and passes through a 1-mL syringe barrel containing cotton and ending in a cannula bent at a $90^{\circ}$ angle. The cannula is readily flame-sterilized between vessels.

Some procedures, such as preparing cultures for freezing, were performed in a controlled atmosphere glove box (Coy Laboratories). The atmosphere in this chamber is approximately $90 \%$ nitrogen and $10 \%$ hydrogen.

\section{Gas Analysis}

The volume of gas produced in a sealed serum bottle is measured with a wetted glass syringe fitted with a small needle (i.e., 25 gauge). The barrel of the wetted syringe is pushed out until the internal and external pressures are equal. For chemical analysis of hydrogen content, a small amount (ca. $500 \mu \mathrm{L}$ ) of headspace gas is injected into an Antek gas chromatograph (GC) equipped with a thermal conductivity detector. The column is $0.32-\mathrm{cm}(1 / 8$-in.) stainless steel $9.1 \mathrm{~m}$ (30 feet) in length and packed with HayeSep DB at 100/120 mesh. The GC is calibrated with a standard injection of a known volume of gas with a known concentration.

\section{Results and Discussion}

Two species of Thermotoga have been obtained from the Deutsche Sammlung von Mikroorganismen und Zellkulturen GmbH, in Braunschweig, Germany. These bacteria are Thermotoga maritima DSM 3109 and Thermotoga neapolitana DSM 4359. Initially these cultures were ordered from the American Type Culture Collection (ATCC), but they were unable to fill the order.

The culture of Thermotoga neapolitana was revived and subjected to repeated static culture at $70^{\circ} \mathrm{C}$ in serum bottles and Hungate tubes on the medium used by van Ooteghem using glucose and other carbohydrates. Cultures of this bacterium have also been stored frozen at $-85^{\circ} \mathrm{C}$. Initially, growth was rapid under these conditions with glucose, but later cultures appeared to slow down. Cultures of Thermotoga neapolitana have also been inoculated into media containing other carbohydrates for adaptation and testing. These other carbohydrates include cellulose, cellobiose, starch, maltose, and lactose. These carbohydrates were selected as being representative of the most common plant-derived sugars, plus lactose, an abundant sugar in dairy waste. 
After initial good growth of T. neapolitana later became poor with starch, an alternate media was tested to determine if growth on starch can be improved. The media tested was the alternate media shown above. Growth on this media was also poor. Therefore, we switched to the use of the Thermotoga maritima DSM 3109. This bacterium was revived and inoculated into DSM-recommended media, then inoculated into a variety of other media (van Ooteghem, improved Childers and alternate) using starch, cellulose, cellobiose, maltose lactose, and glucose as carbon sources. Growth of this strain was conducted at the optimum temperature of $80^{\circ} \mathrm{C}$ under otherwise similar conditions. After repeated culturing of T. maritima on these media and carbon sources, headspace hydrogen concentrations were measured using GC.

All of the growth media used has a degree of turbidity and/ or color, preventing reasonable ascertainment of growth visually or colorimetrically. We investigated using a protein measurement method to determine growth, but found that media components, especially yeast extract, interfered strongly with the analysis. Therefore, we decided to rely on a measurement of the hydrogen in the headspace as a measure of microbial activity. As a result, we prepared a large number of cultures in serum bottles of each of the selected media, van Ooteghem, improved Childers, and alternate, each with a variety of carbohydrates as the carbon source at 5 g/L.

The two species of Thermotoga were each incubated at their optimal temperature, and at time intervals of 48, 72, and $120 \mathrm{~h}$, the headspace was analyzed for hydrogen content. In no case was hydrogen detected in these cultures. This result was deeply concerning, and resulted in additional tests. These tests included longer-term incubations, retesting with fresh media, and examinations of the existing cultures. The existing cultures were examined for the presence of the proper morphology of microorganisms. The morphology was tested by examining fresh wet mounts under 400X and 1000X using phase contrast microscopy.

Thermotoga maritima DSM 3109 cultures and those of Thermotoga neapolitana DSM 4359 were that of rods or cocco-bacillary. The coccus-like structure is the "toga" characteristic of this genus. Cells numbers were medium to low in these cultures.

\section{Conclusions}

Although initial success was obtained in culturing $T$. neapolitana, later growth was poor. A variety of media were tried in attempts to improve growth without good success. Similar results were found when culturing T. maritima. Despite the generally poor growth observed, attempts were made to demonstrate hydrogen production from a variety of carbohydrates, including monosaccharides, disaccharides, and polysaccharides. In no case, with either species of Thermotoga, in a variety of media and with different carbon sources, was hydrogen detected in the headspace of the cultures. The detection limit for the GC used was estimated at less than $0.5 \%$. A number of reasons for these poor results are possible. Chief among these is that these cultures were obtained from a German source well after the terrorist events in the United States of September 11, 2001. At that time, there was a certain level of hysteria and concern, especially with biologicals. As a result, it is very likely that the bacterial strains had been x-rayed. The treatment with $\mathrm{x}$-rays may not have sterilized the cultures, but severely impacted their normal ability to growth without additives. 


\section{SUBTASK 1.4 - DEVELOPMENT OF MANAGEMENT OPTIONS FOR BIOMASS COMBUSTION BY-PRODUCTS}

\section{Introduction}

Combustion of biomass fuels either alone or in conjunction with coal has the potential to result in by-products with different characteristics than $100 \%$ coal or other fossil fuels. Coal-biomass by-products are expected to be appropriate for some utilization applications, but the primary issue of cocombustion of biomass with coal relates to fly ash use as a mineral admixture in concrete. The American Society for Testing and Materials (ASTM) has an existing standard specification for $100 \%$ coal fly ash for use in concrete (9). Some coal-biomass fly ash has been shown to meet the technical specifications noted in this standard (C618); however, the definition of fly ash in the standard indicates that it refers to fly ash produced only from $100 \%$ coal as the fuel. There is an ongoing debate whether ASTM should modify the definition of fly ash or develop an alternate standard for cocombustion fly ash. The ASTM Subcommittee C 9.24 has decided to postpone any action until technical data have been presented to support a position in this debate. In addition, coal-biomass by-products may have applicability in other applications, but this has not been well investigated. The EERC proposes to continue work in this area to support ASTM activities in assembling adequate data that will provide a baseline from which the subcommittee can proceed with confidence.

Combustion by-product utilization has been an area of research at the EERC for over 20 years. Coal-biomass and biomass by-products require similar evaluation before they can be managed effectively, so it is proposed to use the experience and facilities developed through the ongoing coal ash research to develop a program to characterize a limited number of coal-biomass ash samples for properties that are important in facilitating by-product management decisions, especially as they relate to use in concrete. One part of this effort will be to develop a database of the characterization data already available at the EERC and generated under this effort. This effort will be modeled after the very successful Coal Ash Properties Database, which grew from a simple spreadsheet cataloging both physical and chemical parameters of fly ash collected from both full-scale combustion units and bench-/pilot-scale tests conducted in our test facilities. By putting all of the information in a single place, researchers were able to look at, sort, and compare large data sets to look for trends and relationships. When the coal-biomass and biomass by-product characterization data are in a single place as a research tool, it will facilitate improved by-product management and comparisons with existing coal combustion by-product data. This project will investigate the technical appropriateness of coal-biomass and biomass combustion for utilization scenarios.

\section{Experimental}

The experimental plan comprises the following tasks.

Task 1 - Literature Review, Assessment, and Assembly of Annotated Bibliography. A search was performed to obtain additional documentation on combustion and gasification of 
biomass fuels, the resulting by-products, and the management of those by-products. An annotated bibliography was prepared.

Task 2 - Sample Collection and Generation. Samples previously collected from the EERC bench- and pilot-scale combustion tests were included in this subtask; however, some samples were not available in adequate quantity to perform all testing. By-products from full-scale coal-biomass, biomass combustion, and gasification tests were obtained. One sample was generated in the EERC transport reactor development unit (TRDU) jointly with another subtask in Year 1 of the Cooperative Agreement, but the sample generated was not of adequate quality or quantity.

Task 3 - Develop Laboratory Data. Samples of coal-biomass fly ash, biomass ash, and gasification ash will be evaluated for chemical composition and standard physical/engineering properties key for utilization. Bulk major chemical composition of fly ash provides an indication of chemical reactivity of fly ash in concrete systems, including the potential for the fly ash to contribute to concrete failure mechanisms such as alkali-silica reactivity (ASR) and sulfate attack. Particle size, strength development, and expansion tests are also key to determining the appropriateness of fly ash for use as a mineral admixture in concrete. These tests also provide information that relates to nonconcrete utilization applications. Engineering testing parameters consisted of particle fineness, evaluation for use in concrete, ASR reactivity, and sulfate resistance. Testing for particle fineness was performed using a Malvern particle analyzer.

Fly ash being sold for admixture with portland cement in concrete typically must meet the specifications contained in ASTM Standard Test Procedure C618 "Specification for Fly Ash and Raw or Calcined Natural Pozzolan for Use as a Mineral Admixture in Portland Cement Concrete." Since valuable sales contracts can be lost if test results indicate that a fly ash does not meet these specifications, it is important for utility companies and ash marketers to understand the inherent variability associated with tests used to evaluate fly ash. It is also important to be able to estimate the variability of C618 test results when they affect the marketability of fly ash. For example, if the test results indicate, by a narrow margin, that a fly ash fails to meet a particular specification, a question may arise as to whether the ash is actually unacceptable or, possibly, that the test result is inaccurate. To answer this type of question, the intralaboratory standard deviations can be used to estimate the probability that a single test result has incorrectly indicated that a fly ash does not meet a particular specification. If that probability is high, it may be prudent to have the test repeated to verify the result.

ASTM is probably the most widely recognized and used national standards setting organization in the United States for engineering-related materials and testing. The ASTM C618 specification is the most widely used because it covers the use of fly ash as a pozzolan or mineral admixture in concrete. The three classes of pozzolans are Class N, Class F, and Class C. Class N is raw or calcined natural pozzolan such as some diatomaceous earths, opaline cherts, and shales; tuffs, volcanic ashes, and pumicites; and calcined clays and shales. Class F is pozzolanic fly ash normally produced from burning anthracite or bituminous coal. Class $\mathrm{C}$ is pozzolanic and cementitious fly ash normally produced from burning lignite or subbituminous coal. Table 7 shows the chemical and physical requirements listed in the ASTM C618 specification. 


\section{ASTM C618 Chemical Requirements}

The purpose of the chemical requirements contained in the C618 specification is to ensure that the fly ash possesses sufficient chemical reactivity to perform properly when added to concrete and to ensure that it does not contain significant amounts of other deleterious materials which could interfere with the performance of the concrete.

\section{Total Oxides}

The purpose of the total oxides requirement of silica, alumina, and iron is to ensure that the fly ash contains sufficient amounts of the necessary constituents to react with available lime. The lower total oxides requirement for Class $\mathrm{C}$ materials recognizes that these will contain significant amounts of $\mathrm{CaO}$, and so the amounts of the other oxides will necessarily be lower for this particular class.

Table 7. ASTM Specification C618-92a Chemical and Physical Specifications

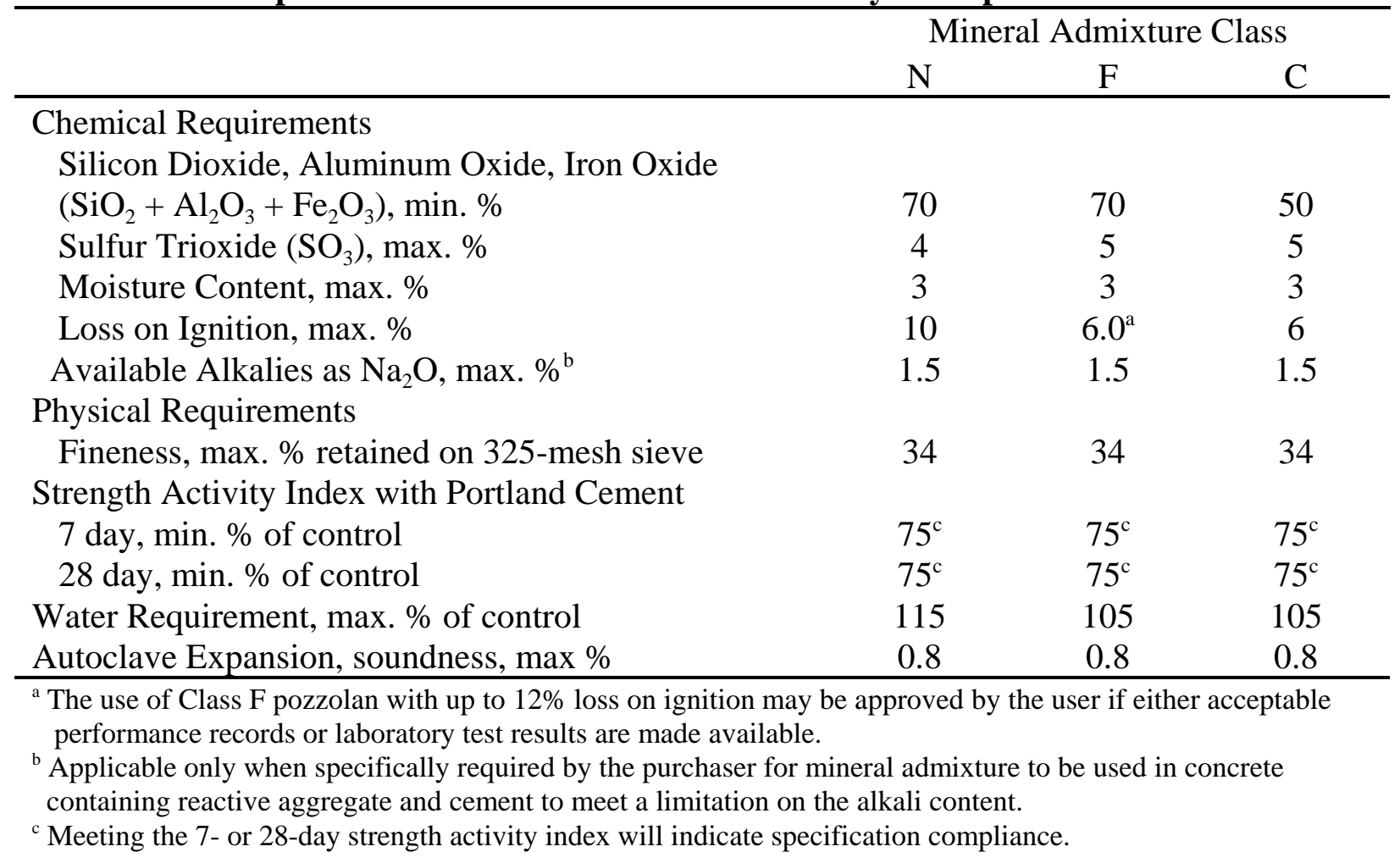




\section{Moisture Content}

A 3.0\% limit is placed on the moisture content of the fly ash to minimize caking and packing of the material during shipment.

\section{Loss on Ignition}

The loss on ignition test is done to measure the unburned carbon content of the fly ash. Carbon in fly ash can affect the air-entraining properties of concrete. Studies have indicated, for example, that fly ash containing high percentages of unburned carbon usually requires higher concentrations of chemical additives to obtain a desired level of entrained air.

\section{Available Alkalies}

The amounts of available alkalies in the fly ash must be limited where aggregates subject to disruptive alkali-aggregate reactions are present. These reactions can cause swelling or cracking of the aggregate, resulting in damage to the concrete. This procedure has recently been removed from the latest edition of the ASTM manuals. The testing began for this research prior to the manual updates, so the testing was included. In addition, many people in the coal ash utilization industry still have a preference for and rely on ASTM's results for verifying an ash for use in concrete. It should be noted that in the time since completion of the laboratory effort, the available alkali procedure has been dropped from the ASTM C618 standard specification $(9,10)$.

\section{ASTM C618 Physical Requirements}

The purpose of the physical requirements contained in C618 is to ensure that the fly ash will perform properly when added to concrete and that the supply of fly ash remains sufficiently uniform over time.

\section{Fineness}

In addition to containing a high percentage of total silica, aluminum, and iron oxides, fly ash particles must be in a finely divided form to properly react with available lime. Fly ash fineness is determined by measuring the amount of material retained after wet sieving through a No. 325 sieve. In addition to the fineness requirement, C618 contains a uniformity requirement which states that the fineness of a sample shall not vary from the average of the ten previous samples from the same source by more than 5 percentage points.

\section{Pozzolanic Activity Index}

ASTM C618 contains pozzolanic activity requirements which relate to its mixture with portland cement. The purpose of the pozzolanic activity tests is to measure the ability of the fly ash to develop strength through chemical reactions with cement. 


\section{Autoclave Soundness}

The autoclave soundness requirement relates to the tendency of mortar bars containing fly ash to either expand or contract during curing. For example, the test protects against the occurrence of the type of delayed expansion which could occur in concrete if sufficient amounts of $\mathrm{MgO}$ are present as periclase, which expands as it hydrates.

\section{Specific Gravity}

The specific gravity of the fly ash is measured as a uniformity check. The specification states that the specific gravity of a sample should not vary from the average of the ten previous samples from the same source by more than 5 percentage points.

\section{Alkali-Silica Reactivity}

ASR is a reaction between alkali hydroxides in portland cement and siliceous phases present in the admixtures and aggregates composed of $\mathrm{SiO}_{2}$. Problems with expansion arise when soluble silica reacts with the alkalies, forming an alkali-silica hydrate gel. In concrete, $\mathrm{CaO}$ is associated with silica and forms a nonswelling calcium silicate hydrate gel during hydration as a key reaction related to cementation.

Fly ash is often added to mitigate expansion due to ASR. Current thoughts on the leading mechanisms by which fly ash controls expansion are that the fly ash dilutes the alkali content in the cement, fly ash removes some of the alkalies from the pore solution by binding them into $\mathrm{CaO}-$ silica hydrate gels, and fly ash reduces the concrete permeability and diffusivity by the silica reacting with the $\mathrm{Ca}(\mathrm{OH})_{2}$ produced by the hydration of the cement to form calcium silicate hydrate. Since the calcium silicate hydrate takes up more space than the $\mathrm{Ca}(\mathrm{OH})_{2}$, the pore systems become finer and less continuous. The reduced porosity limits the ability of the alkalies to migrate and, therefore, reduces the ability of alkali-silica gel to form.

The samples tested for ASR are listed in Table 8. Several of the samples tested for ASTM C618 analyses were not included because of the insufficient amounts of available material. The method used for ASR evaluation was ASTM C441 "Effectiveness of Mineral Admixtures or Ground Blast-Furnace Slag in Preventing Excessive Expansion of Concrete Due to the Alkali-Silica Reaction.” This test method covers the determination of the effectiveness of mineral admixtures or slag in preventing the excessive expansion caused by reaction between aggregates and alkalies in portland cement mixtures. The evaluation is based on the expansion developed in mortar bars by a combination of high-alkali portland cement and a mineral admixture, made with reactive aggregates (Pyrex glass), during storage under prescribed conditions of testing. 
Table 8. Biomass Samples Tested for Alkali-Silica Reactivity

\begin{tabular}{lcc}
\hline & CARRC No. & Description \\
\hline $02-456$ & $02-052$ & Cocombustion fly ash, Weston, 4/19/99 \\
$02-826$ & $02-066$ & Minnesota Power biomass fly ash, Unit 2 \\
$02-1108$ & $02-075$ & TVA Colbert fossil plant 3\% BACA ${ }^{\mathrm{a} / \text { wood waste }}$ \\
$03-072$ & 37680 & \\
$03-073$ & 37681 & \\
$03-074$ & 37682 & \\
\hline
\end{tabular}

${ }^{a}$ By-product aromatic carbocyclic acid.

\section{Sulfate Resistance}

It is quite common in cold weather climates for salts to be applied to concrete surfaces to reduce ice accumulation and skidding. Oftentimes, these salts are blended with sands for distribution. Concrete surfaces, particularly bridge decks, can be hard hit by this sulfate attack. If the exposed section of highway is not extensive in length, liquid sealers can be applied to the freshly hardened concrete surface. However, for extensive miles of treatment, it would be costprohibitive to use expensive surface treatments. Testing concrete for sulfate resistance is designed to simulate field conditions whereby these sulfate environments can be evaluated for their effects on concrete and/or mortar mixtures.

The biomass samples tested for sulfate resistance are the same as those evaluated for ASR, which are listed in Table 7. The standard test method used here for evaluating mineral admixtures for sulfate resistance is ASTM C1012 "Length Change of Hydraulic-Cement Mortars to a Sulfate Solution." This test method covers the determination of length change of mortar bars immersed in a sulfate solution. It provides a means of assessing the sulfate resistance to be expected of concretes and mortars made using portland cement, blends of portland cement with pozzolans or slags, and blended cements. The standard exposure solution used in this test method contains a $5.0 \%$ concentration of sodium sulfate $\left(\mathrm{Na}_{2} \mathrm{SO}_{4}\right)$. Other sulfates and concentrations are allowed in this procedure, but sodium sulfate is the one prescribed in the methodology.

ASTM C1012 also allows for different types of cements to be used in the mortar mixtures. The most commonly used cement in this procedure is Type $\mathrm{V}$, which is designed to resist sulfate solution attack. Other types of cements allowed are Type II, which is a standard type normally used in concrete applications, and blended cements, which are commercially available cements that have already been blended with coal combustion fly ash.

Task 4 - Develop a Characterization Database. A large amount of analytical data from coal-biomass fuels and ash exists at the EERC. All ash-related data will be collected and inventoried. A very simple database will be started with the physical and chemical parameters available.

Task 5 - Reporting and Information Dissemination. Information dissemination for the results based on coal-biomass fly ash will involve communication with the ASTM C 09 
Committee on Concrete and Concrete Aggregates, including attendance at a minimum of one committee meeting to summarize assembled results. Required reports will be prepared, and an appropriate journal article or conference presentation will be prepared.

\section{Results and Discussion}

Task 1 - Literature Review, Assessment, and Assembly of Annotated Bibliography. The literature search was finalized with completion of a formal annotated bibliography. The annotated bibliography contains 25 citations and associated summaries and will be included in full in the final subtask report.

Task 2 - Sample Collection and Generation. Sample collection was a greater effort for this subtask than was originally anticipated. The level of interest in the characteristics of coal-biomass ash expressed by utility ash managers and ash marketers had indicated that coal-biomass ash samples would be relatively easy to obtain. This was not the case. Researchers worked within the EERC to assess the existing catalogue of EERC biomass-related ash samples. Numerous biomass ash samples were catalogued; however, very few coal-biomass ash samples were available from EERC bench- and pilot-scale combustion facilities or full-scale facilities. In most cases, the sample size was extremely limited and inadequate for the testing required to evaluate the ash for appropriateness as a mineral admixture in concrete. Samples were requested from utilities that had performed coal-biomass combustion tests, were planning coal-biomass combustion tests, and regularly used biomass as a cofuel. The samples obtained and used in most of the laboratory testing are noted in Table 9.

Task 3 - Develop Laboratory Data. The engineering test program consisted of ASTM C618 for chemical and physical analyses, particle-size distribution, sulfate resistance, and alkali reactivity. The complete ASTM C618 data sheets will be provided in the final report, and the data can also be viewed through the Ash Behavior Committee (ABC) Database, which is discussed later. The wide variance in biomass samples has resulted in a broad spectrum of chemical and physical characteristics according to ASTM C618 procedures. The total silicon, aluminum, and iron oxides ranged from $27.62 \%$ to over $90.0 \%$. The total oxides for these three elements are the dividing line for classification of coal combustion fly ashes according to ASTM C618. The differences were reflected in either higher levels of calcium oxide or loss on ignition. Higher levels than normal, for fly ash, can also be found in magnesium, sodium, and potassium oxides on the biomass samples. Some samples would not meet the ASTM requirements for use as partial cement replacement in concrete because of high levels of loss on ignition. The specification calls for a loss on ignition not to exceed 6.0\%. Most of the biomass samples have loss on ignition measurements exceeding $10.0 \%$.

Two of the physical parameters, according to ASTM C618, closely relate to one another. They are the No. 325-mesh fineness and the cement activity index (CAI). The fineness procedure is a wet-sieve analysis which determines the amount of ash retained on a No. 325-mesh (45- $\mu \mathrm{m})$ screen. The maximum allowable retainment is $34.0 \%$. The CAI is a ratio, expressed as a percent, between the compressive strength of a mortar-containing cement and ash to that of a mixture 
Table 9. Sample Description

\begin{tabular}{|c|c|c|c|c|c|}
\hline Sample No. & Scale & Coal Percent and Type & Biomass Percent and Type & System Description & Other \\
\hline $02-052$ & Full & 95\% PRB subbituminous & 5\% waste paper & Hot-side ESP & \\
\hline 02-053 & Full & 77\% subbituminous & 23\% sunflower hulls & Baghouse & \\
\hline 02-053 (sieved) & Full & $77 \%$ subbituminous & 23\% sunflower hulls & Baghouse & \\
\hline $02-054$ & Full & 77\% subbituminous & 23\% sunflower hulls & Multicyclone & \\
\hline 02-066 & Full & $60 \%$ subbituminous & $40 \%$ unidentified & & \\
\hline 02-075 & Full & 97\% eastern bituminous & 3\% BACA/wood waste & & \\
\hline 37680 & Full & $92 \%$ bituminous & $8 \%$ furniture manufactured waste & Low-NO ${ }_{x}$ burner/ESP & Condition 1 \\
\hline 37681 & Full & $92 \%$ bituminous & $8 \%$ furniture manufactured waste & Low-NO burner/ESP & Condition 2 \\
\hline 37682 & Full & $92 \%$ bituminous & $8 \%$ furniture manufactured waste & Low-NO ${ }_{\mathrm{x}}$ burner/ESP & Condition 3 \\
\hline
\end{tabular}

${ }^{\mathrm{a}}$ Electrostatic precipitator. 
containing only cement, also referred to as a "control." The minimum requirement here is for the test mixture to have a CAI of $75 \%$. The biomass ashes had finenesses ranging from $3.34 \%$ to over $98.0 \%$. In most instances, the activity index decreases as the fineness increases. An ash sample needs to only surpass the 7- or the 28-day activity index to be considered passing the CAI procedure. However, in instances where a biomass sample passed only one of the CAI specifications, other characteristics exceeding specification limits would prohibit the material to be used as a commercial product for partial replacement of cement in concrete. In most cases, other selections of utilization would need to be considered.

Coal Ash Resources Research Consortium ${ }^{\circledR}\left(\right.$ CARRC $\left.^{\circledR}\right)$ Samples 03-001 through 03-003 resulted in high CAI values. The reasoning for this is most likely due to the extremely low retainment on the No. 325 sieve. The values obtained here are exceedingly low when compared to more traditional precipitator coal ashes. The high loss-on-ignition contents for these three samples are too high for consideration as an admixture additive in concrete. Assuming the utilization market is economically feasible, the recommendation would be to classify these samples to lower the loss-on-ignition contents. Air classification has been used in this manner to benefit several sources of coal combustion ash and is commercially available.

The biomass sample which would make the best candidate for use as partial cement replacement in concrete would be CARRC Sample 02-052. All physical and chemical parameters, with the exception of the available alkali, were successfully met for specification limits. However, considering the final available alkali value exceeded the specification by a relatively small amount and the fact this procedure is no longer listed in ASTM C618 specifications, the biomass sample would still be a good candidate in a portland cement concrete application.

Testing for ASR requires the fabrication of a control test mixture which does not incorporate the usage of a mineral admixture. From the calculated data, the reduction of mortar expansion is derived. This ASTM test procedure has been performed several times in the past by the EERC. The historical test data are given in Table 10 for comparison purposes to the biomass samples. The test results for the biomass samples are given in Table 11.

Table 10. Previous Testing at the EERC for Alkali-Silica Reactivity

\begin{tabular}{lcc}
\hline Sample Description & $\begin{array}{c}\text { Average Length Expansion, } \\
\%\end{array}$ & Reduction of Expansion, \% \\
\hline Control (1992) & 0.406 & - \\
Control (1994) & 0.379 & - \\
Control (1996) & 0.372 & - \\
Class C Fly Ash (1992) & 0.165 & 59.3 \\
Class C Fly Ash (1994) & 0.157 & 58.5 \\
Class C Fly Ash (1996) & 0.166 & 55.4 \\
\hline
\end{tabular}


Table 11. Results of Testing Biomass Samples for Alkali-Silica Reactivity

\begin{tabular}{lcc}
\hline Sample Description & Average Length Expansion, \% & Reduction of Expansion, \% \\
\hline Control (2003) & 0.229 & - \\
CARRC No. 02-052 & 0.125 & 45.4 \\
CARRC No. 02-066 & 0.317 & -38.4 \\
CARRC No. 02-075 & 0.075 & 67.2 \\
CARRC No. 03-001 & 0.059 & 74.2 \\
CARRC No. 03-002 & 0.047 & 79.5 \\
CARRC No. 03-003 & 0.063 & 72.5 \\
\hline
\end{tabular}

With the exception of Sample No. 02-066, all of the selected biomass samples performed very well for this test procedure. Sample 02-066 was the only sample which produced expansion results higher than those exhibited by the control sample. The conclusion can be made that, with the exception of the before-mentioned sample, all of the biomass materials had acceptable reduction of expansion results.

Testing for sulfate resistance also requires the fabrication of a control mixture, containing no mineral admixture. The EERC also has performed this procedure several times over the past years, using difference cements, so this information will be used for comparison purposes here as well. The biomass samples were evaluated using Type V cement, so historical EERC test data will only be on mixtures using this source (Tables 12-14). The results of the biomass testing are contained in Table 15. According to ASTM C595, the maximum allowable expansion at 180 days (6 months) is $0.10 \%$.

Because of delays in sample preparations for this standard test method, there was insufficient time to evaluate the test samples for the entire prescribed length of exposure. Specimens were only exposed to sulfate and subsequently measured for length for 2 months at the time of the writing of this report. The testing will eventually be performed for the prescribed 6 months of exposure. However, those end results will not be available in this document.

Table 12. Average Length Expansions Due to Sulfate Resistance Using Type V Cement, \% (1991)

\begin{tabular}{lcccc}
\hline Specimen Age & Control & Class C Ash 1 & Class C Ash 2 & Class F Ash \\
\hline 1 week & 0.012 & 0.014 & 0.014 & 0.012 \\
2 weeks & 0.015 & 0.016 & 0.018 & 0.014 \\
3 weeks & 0.016 & 0.016 & 0.017 & 0.015 \\
4 weeks & 0.014 & 0.017 & 0.022 & 0.015 \\
8 weeks & 0.019 & 0.022 & 0.025 & 0.021 \\
13 weeks & 0.03 & 0.025 & 0.028 & 0.022 \\
15 weeks & 0.034 & 0.031 & 0.04 & 0.034 \\
4 months & 0.039 & 0.034 & 0.045 & 0.035 \\
6 months & 0.042 & 0.036 & 0.071 & 0.04 \\
\hline
\end{tabular}


Table 13. Average Length Expansions Due to Sulfate Resistance Using Type V Cement, \% (1994)

\begin{tabular}{lccc}
\hline Specimen Age & Control & Class C Fly Ash & Class F Fly Ash \\
\hline 1 week & 0.008 & 0.006 & 0.004 \\
2 weeks & 0.01 & 0.011 & 0.009 \\
3 weeks & 0.012 & 0.012 & 0.01 \\
4 weeks & 0.014 & 0.015 & 0.011 \\
8 weeks & 0.016 & 0.016 & 0.018 \\
13 weeks & 0.023 & 0.026 & 0.027 \\
15 weeks & 0.029 & 0.028 & 0.028 \\
4 months & 0.028 & 0.027 & 0.027 \\
6 months & 0.035 & 0.033 & 0.032 \\
\hline
\end{tabular}

Table 14. Average Length Expansions Due to Sulfate Resistance Using Type V Cement, \% (1996)

\begin{tabular}{lcc}
\hline Specimen Age & Control & Class C Fly Ash \\
\hline 1 week & 0.001 & 0.003 \\
2 weeks & 0.008 & 0.008 \\
3 weeks & 0.011 & 0.011 \\
4 weeks & 0.01 & 0.014 \\
8 weeks & 0.015 & 0.017 \\
13 weeks & 0.02 & 0.021 \\
15 weeks & 0.021 & 0.024 \\
4 months & 0.025 & 0.026 \\
6 months & 0.03 & 0.034 \\
\hline
\end{tabular}

Table 15. Length Expansion Results of Testing Biomass Samples for Sulfate Resistance, \%

\begin{tabular}{llllllll}
\hline Test Age & Control & $02-052$ & $02-066$ & $02-075$ & 37680 & 37681 & 37682 \\
\hline 1 week & 0.009 & 0.006 & 0.008 & 0.003 & 0.004 & 0.008 & 0.007 \\
2 weeks & 0.012 & 0.008 & 0.01 & 0.005 & 0.008 & 0.014 & 0.009 \\
3 weeks & 0.014 & 0.009 & 0.015 & 0.005 & 0.009 & 0.013 & 0.007 \\
4 weeks & 0.017 & 0.01 & 0.017 & 0.006 & 0.01 & 0.016 & 0.01 \\
8 weeks & 0.019 & 0.012 & 0.021 & 0.01 & 0.013 & 0.018 & 0.013 \\
\hline
\end{tabular}

The sulfate resistance results thus far are very good for all biomass samples. Only one sample, 02-066, has expansion values greater than the control mixture used for this procedural method. This, by the way, is also the same sample which failed the ASR expansion procedure. At the present time, all test samples have exhibited acceptable performance for expansion due to sulfate exposure. 


\section{Zeolite Production}

Recently, there has been a strong interest in cocombustion of biomass and coal fuels, partly to explore the use of renewable fuels and relieve $\mathrm{CO}_{2}$ emissions during coal combustion. The resultant biomass-coal fuel blend commonly has elevated alkaline metal and alkaline-earth elements as compared to pulverized coal ash. The elevated alkaline content makes these ashes undesirable for use in many applications that have been identified as beneficial uses for fly ash. Therefore, most biomass-coal blend ashes are disposed of.

Zeolites are a beneficial mineral used for many applications in several different industries. They occur naturally in the southwestern United States where they are formed from the alteration of volcanic ash in alkaline lake deposits. Zeolite synthesis can often be accomplished cheaper than long-distance transportation by adding alkaline compounds to coal combustion by-products (CCBs) and heating them at low temperatures in atmospheric pressures for relatively short periods of time (less than $48 \mathrm{hr}$ ). This work looked to exploit the alkaline content observed in those combustion ashes derived from cofiring biomass and coal blends. It is the high alkaline content, most notably $\mathrm{Na}$ and $\mathrm{K}$, that makes these ashes undesirable for use in most traditional CCB applications associated with the construction industry.

\section{Mineralogy}

Zeolites are a group of hydrated aluminosilicates of the alkali or alkaline-earth metals (primarily $\mathrm{Na}, \mathrm{K}, \mathrm{Mg}$, and $\mathrm{Ca}$ ). Zeolites have 3-dimensional crystalline frameworks of tetrahedral silica or alumina anions strongly bonded at all corners. The zeolite structures contain (-Si-O-Al-) linkages that form surface pores of uniform diameter and enclose regular internal cavities and channels of discrete sizes and shapes, depending on the chemical composition and crystal structure of the specific zeolite involved. Pore sizes range from about 2 to 4.3 angstroms. The enclosed cavities contain both the metal cations and water molecules. The cations are loosely bound to the lattice and can easily engage in ion exchange. The water molecules can also be reversibly driven off in most zeolites.

The pore sizes in zeolites allow them to function for gas adsorption, water adsorption/ desorption, and ion exchange. Gas adsorption is the ability to selectively adsorb specific gas molecules. The ability of activated zeolites to adsorb many gases on a selective basis is, in part, determined by the size of the channels and according to zeolite type. Specific channel sizes enable zeolites to act as molecular gas sieves that can selectively adsorb various gases. Some zeolites have about $47 \%$ void space and a surface area of about $500 \mathrm{~m}^{2} / \mathrm{g}$. This means that this zeolite has a high rate of both sorption and ion exchange capacity. The ability of zeolites to adsorb certain gases makes them ideal for odor control applications. Zeolites are used in public toilets, horse stables, chicken coops, and feed lots that all release ammonia fumes that can cause distress to both animals and humans.

Zeolites can have a high affinity for water and the capability of adsorbing and desorbing water without damaging the crystal structure. This property makes them useful for desiccation 
and heat storage. Zeolites are used industrially to control moisture levels particularly in lowhumidity ranges where other desiccants are less effective.

\section{Synthetic Zeolites}

Zeolites have been produced from fly ash using a hydrothermal alkaline conversion (10-15). Commonly, $\mathrm{NaOH}$ or $\mathrm{KOH}$ solutions are used in atmospheric pressures at temperatures ranging from $80^{\circ}$ to $200^{\circ} \mathrm{C}$ and times ranging from 3 to 48 hours to prepare zeolites from fly ash. Kolay and Singh (14) made zeolites from ponded ash by adding $\mathrm{KOH}$ or $\mathrm{NaOH}$ at various concentrations and times. The temperature they used was $100^{\circ} \mathrm{C}$. Querol and others (13) report an optimum temperature of $150^{\circ} \mathrm{C}$ for zeolite formation when activated by $\mathrm{NaOH}$ and $\mathrm{KOH}$. There are about 40 naturally occurring zeolites, and more than 150 have been synthesized for specific properties such as adsorption, ion exchange, molecular sieve, and catalytic properties (14).

The largest use of synthetic zeolites has been as filler in powder detergents followed by catalytic applications for petroleum refinement. Applications as molecular sieves are minimal, and natural zeolites dominate that market (14).

\section{Experimental}

Two ashes were selected based on their availability and chemistry for zeolite production. Both ashes were the result of full-scale cocombustion of coal and biomass. The chemical compositions as determined by x-ray fluorescence (XRF) are provided in Table 16.

The samples selected were chosen because of the $\mathrm{K}_{2} \mathrm{O}, \mathrm{Na}_{2} \mathrm{O}$, and $\mathrm{CaO}$ content. These ashes were not suitable for application as a mineral admixture or cement replacement in concrete because of the alkaline content.

Table 16. Chemical Composition of Full-Scale Biomass-Coal Ash (wt\%)

\begin{tabular}{|c|c|c|}
\hline Compound & CARRC No. 02-053 & CARRC No. 02-066 \\
\hline $\mathrm{SiO}_{2}$ & 30.05 & 44.71 \\
\hline $\mathrm{Al}_{2} \mathrm{O}_{3}$ & 18.84 & 8.23 \\
\hline $\mathrm{Fe}_{2} \mathrm{O}_{3}$ & 1.28 & 3.8 \\
\hline $\mathrm{CaO}$ & 19.83 & 28.01 \\
\hline $\mathrm{MgO}$ & 8.27 & 2.59 \\
\hline $\mathrm{Na}_{2} \mathrm{O}$ & 0.36 & 2.9 \\
\hline $\mathrm{K}_{2} \mathrm{O}$ & 11.28 & 4.51 \\
\hline $\mathrm{TiO}_{2}$ & 0.97 & 0.31 \\
\hline $\mathrm{MnO}_{2}$ & 0.19 & 0.28 \\
\hline $\mathrm{P}_{2} \mathrm{O}_{5}$ & 2.16 & 1.26 \\
\hline $\mathrm{SrO}$ & 0.43 & 0.14 \\
\hline $\mathrm{BaO}$ & 0.28 & 0.31 \\
\hline $\mathrm{SO}_{3}$ & 6.07 & 2.95 \\
\hline
\end{tabular}


The first attempt to produce zeolites from these materials was a very simple approach in which $5 \mathrm{~g}$ of ash and $100 \mathrm{~mL}$ of water were heated to $90^{\circ} \mathrm{C}$ and stirred for approximately $48 \mathrm{hr}$. The ash was then removed, washed with distilled water, and submitted for x-ray diffraction (XRD) analysis. No zeolites were produced with this method.

Sample 02-066 was then placed in a Parr acid digestion bomb, which can be safely heated to $150^{\circ} \mathrm{C}$. Three preparations were made, with the first being the ash as received, the second with $\mathrm{KOH}$ added, and the third with $\mathrm{NaOH}$ added. For all three preparations, 1 gram of ash was placed in the digestion bomb. Distilled $\mathrm{H}_{2} \mathrm{O}(50 \mathrm{~mL})$ was added to one of the ash samples, and for the initial trial, a very strong alkaline solution was added as described by Querol and others (13). The solutions were prepared as 3 molar solutions of $\mathrm{KOH}$ and $\mathrm{NaOH}$ in which $50 \mathrm{~mL}$ was placed into the digestion bomb with the $1 \mathrm{~g}$ of ash. These were then placed in a Lindberg furnace for

$48 \mathrm{hr}$, being heated to $150^{\circ} \mathrm{C}$. After heating, the samples were removed, filtered, and washed in distilled water. XRD analysis was performed on the three samples.

No zeolites were found by XRD analysis after $48 \mathrm{hr}$ at $150^{\circ} \mathrm{C}$. Figure 19 is the diffractogram of the ash and water with no additional alkali added. The original as-received sample was found to contain lime $(\mathrm{CaO})$ and calcite $\left(\mathrm{CaCO}_{3}\right)$ as minor constituents. After the heating process, the lime was absent, and calcite was a major constituent. A calcium silicate phase also formed during the heating process.

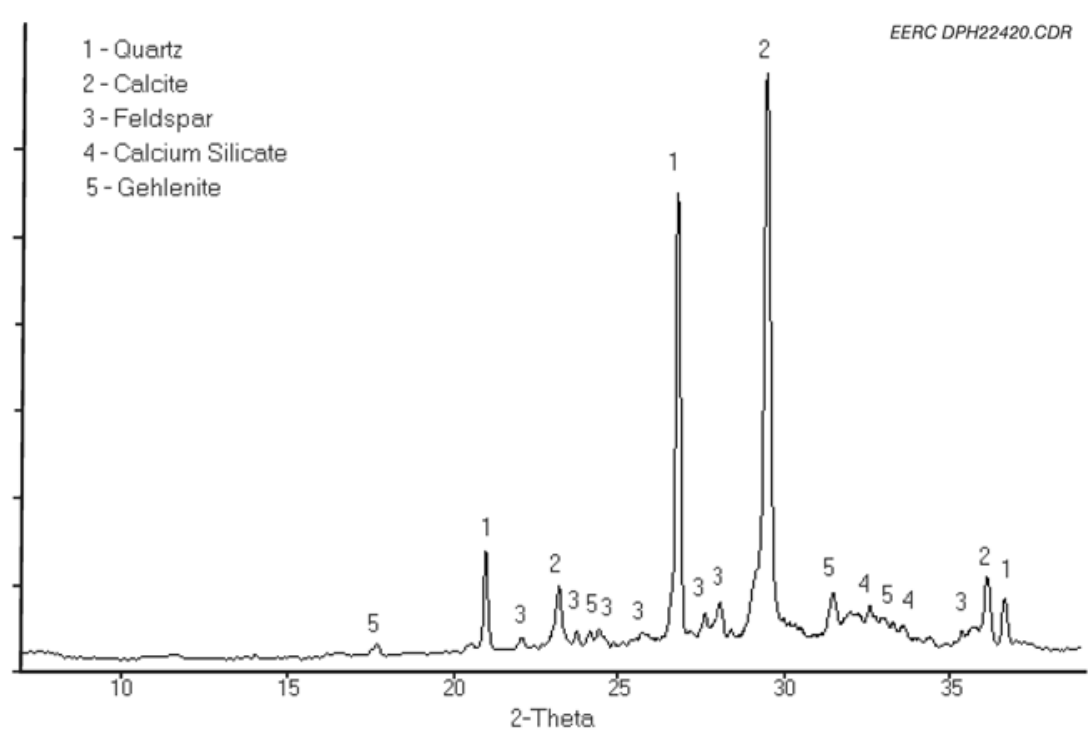

Figure 19. XRD diffractogram of Sample $02-066$ after $48 \mathrm{hr}$ of heating at $150^{\circ} \mathrm{C}$. 
Figure 20 shows the diffractogram of Sample $02-066$ after $48 \mathrm{hr}$ of heating at $150^{\circ} \mathrm{C}$ in the 3 molar solution of $\mathrm{KOH}$. The primary difference in this sample was the formation of small amounts of portlandite, $\mathrm{Ca}(\mathrm{OH})_{2}$, and substantial amounts of tobermorite, $\mathrm{Ca}_{5} \mathrm{Si}_{6}(\mathrm{OH})_{18} \cdot 5 \mathrm{H}_{2} \mathrm{O}$. Portlandite may occur as an alteration product of calcium silicates in elevated $\mathrm{pH}$ conditions where the silicates are beginning to dissolve into the alkaline solutions. Tobermorite is known as a hydrothermal alteration product of calcium carbonate. It is often associated with zeolites, but it does not have the zeolite structure itself.

Figure 21 shows the diffractogram of Sample $02-066$ after $48 \mathrm{hr}$ of heating at $150^{\circ} \mathrm{C}$ in the 3 molar solution of $\mathrm{NaOH}$. When compared to the diffractogram shown in Figure 19, the most noticeable difference is in the number of peaks present. Calcite is absent, and several different sodium carbonate phases were formed.

It appears as though the sodium was overwhelming to the experiment in that it replaced the $\mathrm{Ca}$ in the carbonates and formed several sodium carbonate phases. It is also likely that highcalcium ashes do not perform as well as low-calcium ashes in zeolite formation. The presence of the calcium silicates indicates that the high $\mathrm{pH}$ is causing silicon to go into solution but has a greater affinity for the calcium than the zeolites.

A third attempt to form zeolites from CCBs was tried using CARRC Sample 02-053 and a low-calcium ash from the National Bureau of Standards (NBS), NBS 1633a, which was a standard reference material for trace elements with a known composition. While NBS 1633a is not an ash resulting from a coal and biomass blend of fuel, it was selected for its low $\mathrm{Ca}, \mathrm{Na}$, and $\mathrm{K}$ content to possibly better match the low-calcium ashes described as zeolite formers in the

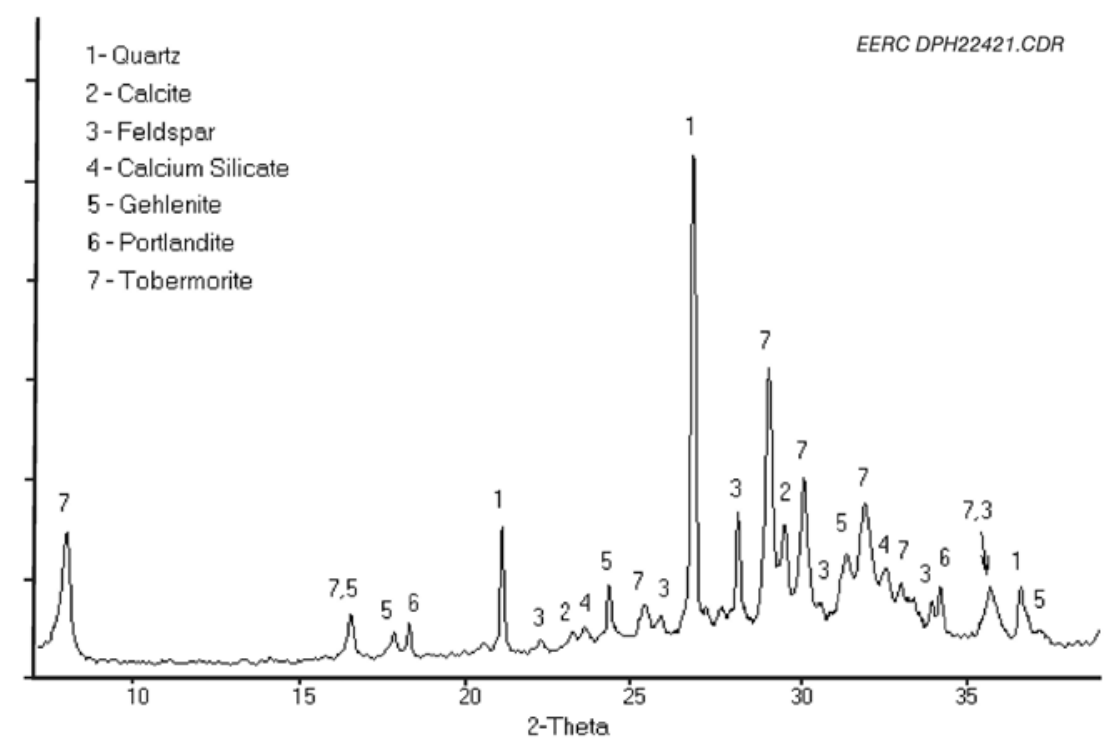

Figure 20. XRD diffractogram of Sample $02-066$ after $48 \mathrm{hr}$ of heating at $150^{\circ} \mathrm{C}$ in a 3 molar solution of $\mathrm{KOH}$. 
literature. Since the initial experiments failed to produce zeolites, an ash with $\mathrm{Si} / \mathrm{Al}$ ratios closer to those with known success was selected. A 1 molar solution of either $\mathrm{KOH}$ or $\mathrm{NaOH}$ was used rather than the 3 molar solutions previously tried. CARRC Sample 02-053 and a sample of NBS 1633a were activated with a 1 molar solution of $\mathrm{KOH}$, and one NBS 1633a sample was activated with $\mathrm{NaOH}$. All three samples were placed in a furnace heated to $175^{\circ} \mathrm{C}$ for $48 \mathrm{hr}$.

CARRC Sample 02-053 formed tobermorite and calcium silicate, but no other phases were found after the treatment. The NBS 1633a sample did form zeolites with both the $\mathrm{NaOH}$ and $\mathrm{KOH}$ solutions. Figure 22 shows the diffractogram of the $\mathrm{NaOH}$ added solution in which zeolite $\mathrm{P} 1$ formed. Zeolite $\mathrm{P} 1$ is a sodium-rich zeolite with the nominal composition of $\mathrm{Na}_{3} \mathrm{Al}_{3} \mathrm{Si}_{5} \mathrm{O}_{16}$. $6 \mathrm{H}_{2} \mathrm{O}$. Tobermorite also formed, but no other zeolites formed.

Figure 23 shows a diffractogram of NBS 1633a that was treated with a 1 molar solution of $\mathrm{KOH}$ at $175^{\circ} \mathrm{C}$ for $48 \mathrm{hr}$. As in the $\mathrm{NaOH}$-treated sample, zeolite $\mathrm{P} 1$ formed. Two other zeolite phases were also identified. Merlinoite and an unnamed potassium zeolite were identified. The nominal composition for merlinoite is $\mathrm{K}_{5} \mathrm{Ca}_{2}\left(\mathrm{Al}_{9} \mathrm{Si}_{23} \mathrm{O}_{64}\right) \cdot 24 \mathrm{H}_{2} \mathrm{O}$, and the unnamed zeolite phase has a nominal composition of $\mathrm{K}_{2} \mathrm{Al}_{2} \mathrm{O}_{4} \mathrm{SiO}_{2} \cdot \mathrm{H}_{2} \mathrm{O}$. There is a large amorphous component not seen in the $\mathrm{NaOH}$-treated sample, and phases such as quartz, mullite, and anorthite were still identifiable in this sample and essentially absent in the $\mathrm{NaOH}$-treated sample.

Task 4 - Develop a Characterization Database. When the database development task was first initiated, small samples of coal-biomass fuel, coal samples, biomass samples, and ash from fuel and fuel blends were sought out and collected for input into the database. Once the majority

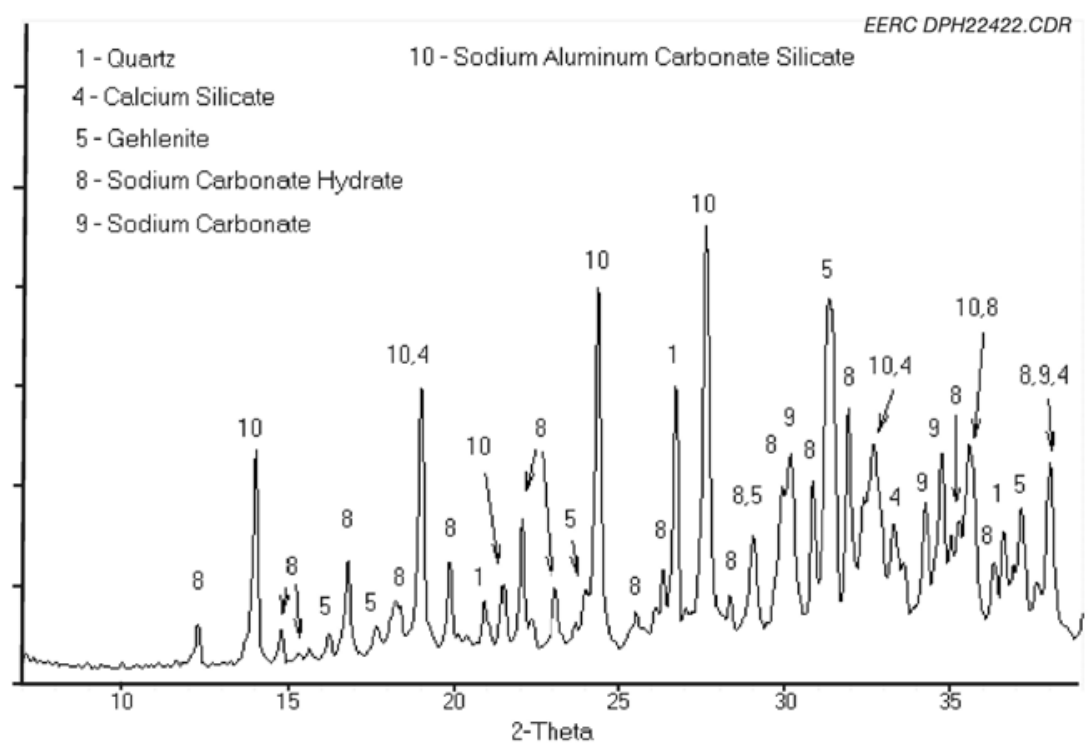

Figure 21. XRD diffractogram of Sample $02-066$ after $48 \mathrm{hr}$ of heating at $150^{\circ} \mathrm{C}$ in a 3 molar $\mathrm{NaOH}$ solution. 


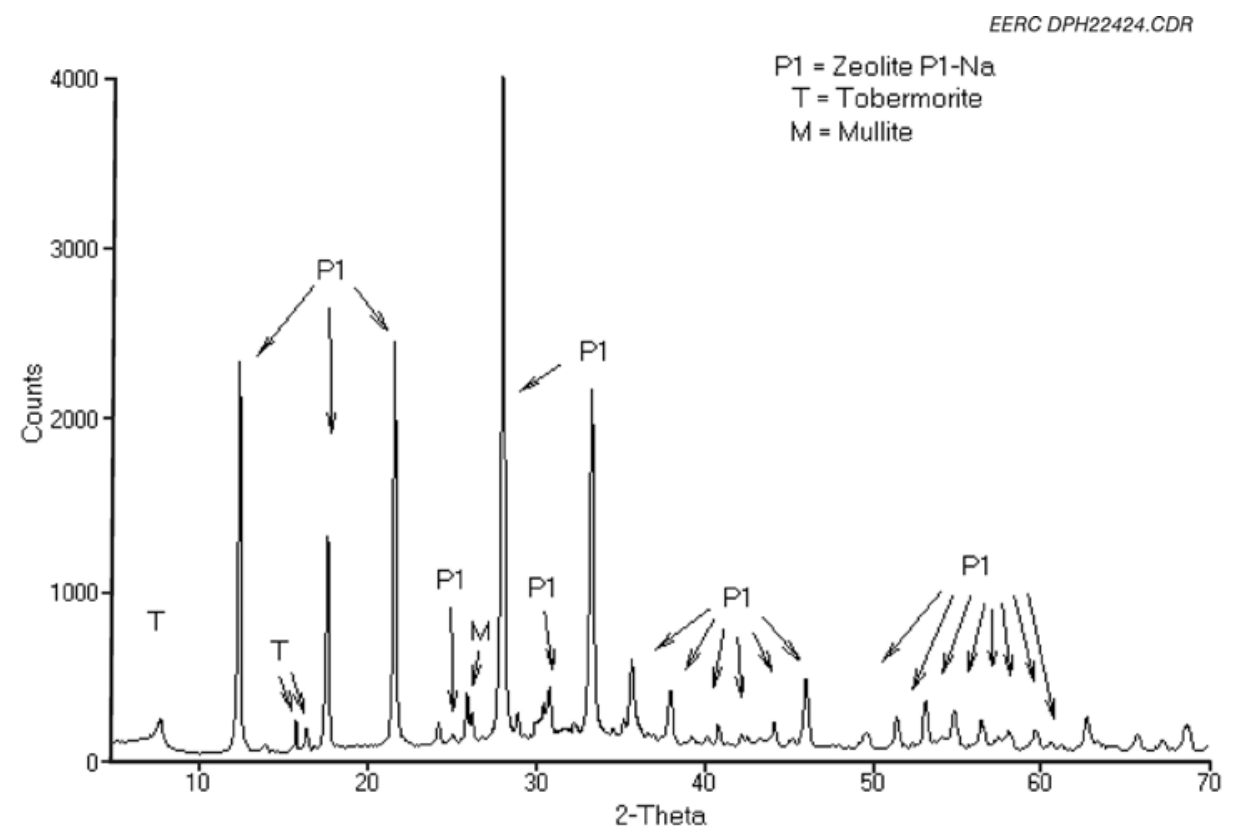

Figure 22. Diffractogram of NBS 1633 a after $48 \mathrm{hr}$ at $175^{\circ} \mathrm{C}$ in a 1 molar solution of $\mathrm{NaOH}$.

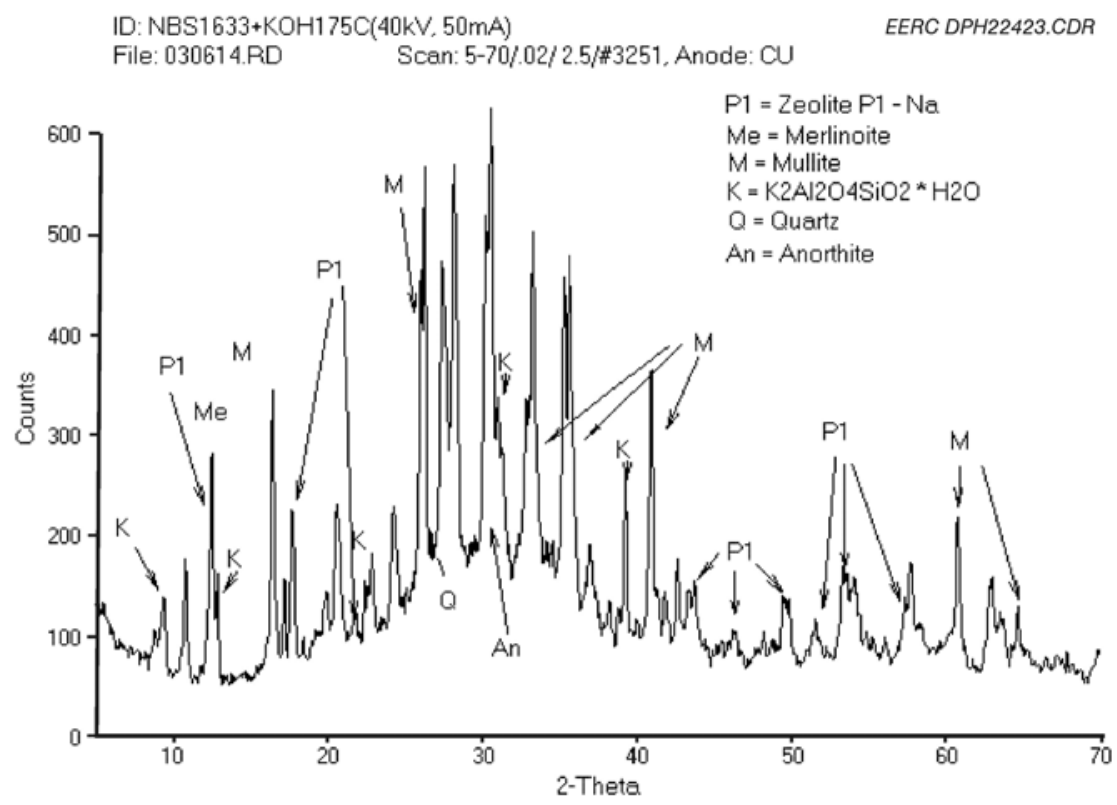

Figure 23. Diffractogram of NBS 1633 a heated for $48 \mathrm{hr}$ at $175^{\circ} \mathrm{C}$ in a $\mathrm{KOH}$ solution. 
of the sample data was collected, it was entered into tables of the database, either by the importing of already-electronic data or by data entry. The analyses performed on these particular samples that have been collected include ASTM C618, computer-controlled scanning electron microscopy (CCSEM), Malvern, XRD, and x-ray fluorescence (XRF).

After data were collected and entered into tables in the database, relationships were established among tables to better query the data to obtain desired information. After proper querying was completed, forms and reports were generated to make the database more effective. The forms are used to enter in new data as well as to view and edit current data. Reports were generated for viewing purposes only.

At this point, a menu system was developed in order to make the database user-friendly. The menu system gives the user the option to view a variety of forms and reports and to efficiently view, manipulate, and add data.

Once the work on the database itself was complete, a user's manual composed of text and images of the database was developed to assist users with questions they may have when navigating the database.

\section{Conclusions}

Laboratory experiments indicated that when biomass is cocombusted with coal at low percentages, it can meet ASTM C618 requirements for use as a mineral admixture in concrete. Higher percentages of biomass, however, such as $>20 \%$, result in a fly ash that generally does not meet the ASTM C618 requirements. Zeolite production from high-calcium and high-alkali biomass-coal ash was not accomplished using methodologies that are normally successful for low-calcium ash. Precursors to zeolites were formed under the most extreme conditions used, so zeolite formation is expected to be possible with different conditions. The ABC database can be used by industry to review specifications and definitions of fly ash for use as a mineral admixture in concrete.

\section{SUBTASK 2.1 - ETHANOL PROCESSING FOR FUEL CELLS}

\section{Introduction}

The use of ethanol as a hydrogen source for proton exchange membrane (PEM) fuel cells, solid oxide fuel cells (SOFCs), as well as other fuel cells, offers several inherent advantages over other fuels. The temperature required for catalytic partial oxidation (cPOX) reforming of ethanol to a hydrogen-rich gas is lower than required for reforming gasoline, diesel fuel, naphtha, natural gas, or propane. These fuels, along with methanol, represent the primary commercial liquid and gaseous fuels being seriously investigated for fuel cell applications. The lower cPOX temperature requirements simplify materials selection and reduce waste heat. 
A second advantage of ethanol is the absence of sulfur compounds which are a major fuel cell contaminant that can poison reformer and shift catalysts. Sulfur is a component of gasoline, diesel fuel, natural gas, and naphtha and would need to be removed from the fuel prior to use in a fuel cell application. In the case of natural gas and propane, sulfur is added as an odorant and similarly would need to be removed in the reforming process. In addition to eliminating the need for sulfur removal, ethanol reforming can be done with a less expensive, or a lesser amount of, catalyst, and the potential for sulfur contamination of expensive fuel cell components is near zero. Although the two most common ethanol denaturants used today — gasoline and natural gas liquids (NGL) - contain sulfur, denaturing with methanol (if acceptable to the U.S. Treasury Department) would retain ethanol's advantage as a sulfur-free hydrogen feedstock.

The miscibility of ethanol and water provides another advantage for cPOX because the reforming process requires water to maximize hydrogen production. The fact that ethanol and water are completely miscible may also be beneficial to some fuel cell applications. The option of having water premixed with fuel would simplify processor design by eliminating the need for a separate water-handling system and would also guard against freezing. Further, because ethanol contains oxygen, less air is required for the fuel cell reaction, requiring less nitrogen flow through the system. Nitrogen is an energy-free diluent, and reduced nitrogen flow translates to lower cost and higher efficiency.

Unlike both natural gas and propane, ethanol is a liquid at room temperature, which simplifies transportation, storage, and dispensing operations. Additionally, it can be supported by existing infrastructure and applied to portable and remote power generation. Ethanol is also less toxic than all other liquid fuels being investigated for fuel cell applications, which would further simplify fuel distribution systems.

These characteristics of ethanol make it an excellent candidate for distributed and largescale hydrogen production, as well as on-board reforming applications. For distributed applications, infrastructure exists to support transportation and storage of liquid ethanol. Largescale applications also benefit from the availability of the easily handled feedstock. On-board reforming has posed several challenges to the automobile industry, including excessive fuel processor size and heat-transfer requirements, PEM sensitivity to sulfur and other impurities, and maximizing catalyst life, each of which can be addressed by using an ethanol feedstock. The miscibility of ethanol and water and inherent oxygen reduces the volume of feed, which accommodates a smaller fuel processor. The absence of sulfur and simple molecular structure eliminates the need for on-board sulfur removal and reduces fuel processor catalyst requirements. Finally, the easily reformed ethanol molecule and absence of sulfur reduce heattransfer requirements, further simplifying the process.

In order to capitalize on the technical advantages of ethanol as a source of hydrogen for fuel cells, research has been conducted at the University of North Dakota EERC to develop/optimize a cPOX-based concept for a simple, low-cost fuel processor (reformer). 


\section{Experimental}

\section{Objectives and Experimental Design}

The objectives of the experimental work were to 1) evaluate the effect of reforming reaction conditions - including temperature, air injection rate, and water injection rate - on hydrogen yield and catalyst coking; 2) evaluate state-of-the-art catalysts for cPOX ethanol reforming based on hydrogen yield and catalyst coking; 3) establish the best combination of catalyst and reaction conditions within the test matrix; and 4) compare the hydrogen yield and extent of catalyst coking from ethanol with several different denaturants, including methanol $(\mathrm{MeOH})$, regular unleaded gasoline (RUG), and NGL. Table 17 displays the test matrix developed for evaluation of reaction parameters and catalysts.

In cPOX, $\mathrm{O}_{2}$ participates in reforming the hydrocarbons while supporting the thermal load required to sustain the hydrogen production process. In order to determine the effect of oxygen (air) on gas species production during ethanol reforming, a series of tests were performed with three catalysts, each at three different mole fractions of oxygen. These tests were conducted in the absence of water and at ratios of $0.1,0.25$, and 0.5 mole of oxygen to 1 mole of ethanol. The three oxygen mole fractions tested were selected based on a desire to remain below stoichiometric requirements and ensure partial oxidation. The best oxygen ratio for the ethanol reforming was selected based on the greatest hydrogen production and was used to evaluate the optimum water-to-fuel ratio in the second set of tests. In the end, low oxygen is desirable for maximizing hydrogen production.

The evaluation of water-to-fuel ratios was conducted with the same criteria used for oxygen. Tests were performed with three catalysts at each of three mole fractions of water: 0.1, 0.25 , and 0.5 . All of these tests were conducted using the oxygen-to-fuel ratio determined as "best" in the previous test set. As with $\mathrm{O}_{2}, \mathrm{H}_{2} \mathrm{O}$ helps to promote carbon gasification to prevent coking, and some $\mathrm{H}_{2} \mathrm{O}$ is required to support water-gas shift. Meeting these requirements without adding excess $\mathrm{H}_{2} \mathrm{O}$ to the reactor is necessary to manage the reactor size and thermal load.

When producing hydrogen for PEM applications, a minimum fuel temperature is desired. By reducing waste heat not utilized or required by a PEM, efficiency can be increased. To evaluate the effect of temperature on the reforming process, an E95/RUG5 (95\% ethanol and 5\% regular unleaded gasoline) fuel was used. Previous tests focused on evaluating the various air and water molar ratios were conducted using $100 \%$ ethanol in an effort to mitigate confounding effects of a denaturant and uncontrolled water content in the fuel. Based on the information gained during these tests, temperature effects were evaluated using the air-to-fuel and water-tofuel ratio determined as "best" in the previous tests. Tests designed to measure temperature effects which were evaluated based on hydrogen production and catalyst coking were conducted at $50^{\circ} \mathrm{C}$ above and below the baseline temperature of $705^{\circ} \mathrm{C}\left(655^{\circ} \mathrm{C}\right.$ to $\left.755^{\circ} \mathrm{C}\right)$. These temperature tests were conducted, not to optimize hydrogen production, but rather to establish trends for these parameters around baseline conditions. 
Table 17. Ethanol cPOX Reforming - Reaction Condition and Catalyst Evaluation

\begin{tabular}{|c|c|c|c|c|}
\hline Fuel & $\begin{array}{l}\text { Temperature, } \\
{ }^{\circ} \mathrm{C}\end{array}$ & Catalyst & $\begin{array}{c}\text { Air } \\
\text { Stoichiometry } \\
\end{array}$ & $\begin{array}{c}\text { Water } \\
\text { Stoichiometry }^{2} \\
\end{array}$ \\
\hline \multicolumn{5}{|c|}{$\begin{array}{l}\text { Select optimum air injection rate based on balance between hydrogen yield and extent of catalyst } \\
\text { coking }\end{array}$} \\
\hline $100 \%$ Ethanol & 704 (baseline) & None & $0.5,0.25,0.1$ & No water added \\
\hline $100 \%$ Ethanol & 704 & 1 & $0.5,0.25,0.1$ & No water added \\
\hline $100 \%$ Ethanol & 704 & 2 & $0.5,0.25,0.1$ & No water added \\
\hline $100 \%$ Ethanol & 704 & 3 & $0.5,0.25,0.1$ & No water added \\
\hline \multicolumn{5}{|c|}{$\begin{array}{l}\text { Select optimum water injection rate based on balance between hydrogen yield and extent of } \\
\text { catalyst coking }\end{array}$} \\
\hline $100 \%$ Ethanol & 704 & None & 0.1 & $0.5,0.25,0.1$ \\
\hline $100 \%$ Ethanol & 704 & 1 & 0.1 & $0.5,0.25,0.1$ \\
\hline $100 \%$ Ethanol & 704 & 2 & 0.1 & $0.5,0.25,0.1$ \\
\hline $100 \%$ Ethanol & 704 & 3 & 0.1 & $0.5,0.25,0.1$ \\
\hline \multicolumn{5}{|c|}{$\begin{array}{l}\text { Select optimum catalyst-temperature combination based on balance between hydrogen yield and } \\
\text { coking }\end{array}$} \\
\hline E95/RUG5 ${ }^{3}$ & $655^{4}$ & 1 & 0.1 & 0.5 \\
\hline E95/RUG5 & 705 & 1 & 0.1 & 0.5 \\
\hline E95/RUG5 & 755 & 1 & 0.1 & 0.5 \\
\hline \multicolumn{5}{|c|}{ Compare denatured fuels } \\
\hline E95/NGL5 5 & 705 & 1 and 2 & 0.1 & 0.5 \\
\hline E85/RUG15 ${ }^{6}$ & 705 & 1 and 2 & 0.1 & 0.5 \\
\hline $\mathrm{E} 95 / \mathrm{MeOH} 5^{7}$ & 705 & 1 and 2 & 0.1 & 0.5 \\
\hline E97/MeOH3 ${ }^{8}$ & 705 & 1 & & \\
\hline E95/RUG5 3 & 705 & 1 and 2 & 0.1 & 0.5 \\
\hline \multicolumn{5}{|c|}{$\begin{array}{l}\text { Molar ratio of oxygen }\left(\mathrm{O}_{2}\right) \text { to ethanol }\left(\mathrm{CH}_{3} \mathrm{CH}_{2} \mathrm{OH}\right) \text {. } \\
\text { Molar ratio of water }\left(\mathrm{H}_{2} \mathrm{O}\right) \text { to ethanol }\left(\mathrm{CH}_{3} \mathrm{CH}_{2} \mathrm{OH}\right) \text {. } \\
\text { 95\% fuel ethanol blended with } 5 \% \text { regular unleaded gasoline. } \\
\text { Incremental reduction to lowest temperature of acceptable performance. } \\
95 \% \text { fuel ethanol blended with } 5 \% \text { natural gas liquid. } \\
85 \% \text { fuel ethanol blended with } 15 \% \text { regular unleaded gasoline. } \\
\text { 95\% fuel ethanol blended with } 5 \% \text { methanol. } \\
\text { 97\% fuel ethanol blended with 3\% methanol. }\end{array}$} \\
\hline
\end{tabular}

The fourth set of tests was designed to compare the hydrogen yield and catalyst coking from reforming ethanol as a function of denaturant. For this series of tests, performance was compared based on the stoichiometric conditions identified for $100 \%$ ethanol in the first two test sets. Fuel ethanol was blended with $\mathrm{MeOH}$, NGL, and RUG in amounts ranging from 3\% to $15 \%$. These tests were conducted on the two catalysts that performed the best in stoichiometric tests.

\section{Reactions}

Reforming ethanol under cPOX conditions can follow several reaction pathways and result in numerous products. It is, therefore, essential that the reaction be optimized for the desired 
products. A few of the possible reactions, ignoring reversibility, involved in reforming ethanol are shown below. Reactions 2, 6, and 8, which includes the reverse Boudouard reaction, are examples of reactions resulting in carbon deposits on the catalyst. For hydrogen production, Reactions 5, 7, and 10 would be optimal.

$$
\begin{aligned}
& \mathrm{C}_{2} \mathrm{H}_{5} \mathrm{OH}+\text { Energy } \rightarrow \mathrm{CO}+\mathrm{CH}_{4}+\mathrm{H}_{2} \\
& \mathrm{C}_{2} \mathrm{H}_{5} \mathrm{OH}+\text { Energy } \rightarrow \mathrm{H}_{2} \mathrm{CO}+\mathrm{C}+2 \mathrm{H}_{2} \\
& \mathrm{C}_{2} \mathrm{H}_{5} \mathrm{OH}+\text { Energy } \rightarrow \mathrm{H}_{2} \mathrm{CO}+\mathrm{CH}_{4} \\
& \mathrm{C}_{2} \mathrm{H}_{5} \mathrm{OH}+\text { Energy } \rightarrow \mathrm{CH}_{3} \mathrm{CHO}+\mathrm{H}_{2} \\
& \mathrm{C}_{2} \mathrm{H}_{5} \mathrm{OH}+3 \mathrm{H}_{2} \mathrm{O} \rightarrow 2 \mathrm{CO}_{2}+6 \mathrm{H}_{2} \\
& \mathrm{C}_{2} \mathrm{H}_{5} \mathrm{OH}+1.5 \mathrm{O}_{2} \rightarrow \mathrm{CO}_{2}+2 \mathrm{H}_{2} \mathrm{O}+\mathrm{C}+\mathrm{H}_{2} \\
& \mathrm{C}_{2} \mathrm{H}_{5} \mathrm{OH}+1.5 \mathrm{O}_{2} \rightarrow 2 \mathrm{CO}+2 \mathrm{H}_{2} \mathrm{O}+\mathrm{H}_{2} \rightarrow 2 \mathrm{CO}_{2}+3 \mathrm{H}_{2} \\
& \mathrm{C}_{2} \mathrm{H}_{5} \mathrm{OH}+0.5 \mathrm{O}_{2} \rightarrow 2 \mathrm{C}+2 \mathrm{H}_{2} \mathrm{O}+\mathrm{H}_{2} \rightarrow 2 \mathrm{CO}+3 \mathrm{H}_{2} \rightarrow \mathrm{CO}_{2}+\mathrm{C}+3 \mathrm{H}_{2} \\
& 2 \mathrm{CO}+\mathrm{H}_{2} \rightarrow \mathrm{CH}_{4} \\
& \mathrm{C}_{2} \mathrm{H}_{5} \mathrm{OH}+0.5 \mathrm{O}_{2}+2 \mathrm{H}_{2} \mathrm{O} \rightarrow 2 \mathrm{CO}_{2}+5 \mathrm{H}_{2}
\end{aligned}
$$

\section{Description of Materials, Instrumentation, and Equipment}

Experimental quantities of three catalysts developed specifically for reforming light alcohols were acquired from several sources, including a national laboratory and commercial catalyst suppliers. In the interest of maintaining confidentiality, catalysts will not be identified, but will be referred to throughout this report as Catalysts 1, 2, and 3. Only two of the catalysts (1 and 2) were tested with different denaturants, and only Catalyst 1 was used in the evaluation of temperature effects.

The bench-scale system used for this program comprised a temperature-regulated reaction chamber containing a catalyst bed; injection systems for ethanol, air, and water; and an analytical system for product gas evaluation. A state-of-the-art thermogravimetric analysis (TGA) system was also configured and integrated into the bench-scale system. The TGA system enables accurate monitoring of catalyst weight gain (due to coking) as a function of reaction conditions.

Product gas composition was determined using two instruments: a Fourier transform infrared (FT-IR) analyzer and a Sick-Maihak S715 component gas analyzer. The FT-IR provides qualitative analysis of the product gas stream and provides identification of functional groups such as carbonyl, hydroxyl, carboxyl, aliphatic, and aromatic compounds. Quantitative analysis of the product gas for hydrogen, carbon dioxide, carbon monoxide, methane, and oxygen was obtained using the Sick-Maihak gas analyzer. During shakedown tests, the results from these instruments were validated by collecting gas samples and analyzing them via gas chromatography (GC).

\section{Results and Discussion}

Preliminary testing was conducted to validate the reactor unit operation and to quantify the product gases produced from cPOX of $100 \%$ ethanol. Product gases were collected in bags and analyzed with a GC. Validations of the FT-IR and Sick-Maihak S715 component gas analyzer 
data were conducted through comparison with GC results. These validation tests confirmed that the reactor system and gas analyzers were functioning properly.

Tests on each of three catalysts resulted in an increase in hydrogen production as the mole fraction of oxygen to ethanol was decreased (without water). In each case, an oxygen mole fraction of 0.1 yielded the highest mole percent of hydrogen out of the three mole fractions evaluated. Catalyst 1 provided the greatest hydrogen yield at an average of approximately 20 mole percent hydrogen. A summary of hydrogen production is provided in Figures 24-26 for Catalysts 1-3, respectively, which show hydrogen produced under cPOX conditions normalized to air feed.

Utilizing an oxygen mole fraction of 0.1 , additional tests were conducted on each catalyst with varying water injection rates to evaluate the amount of water necessary to enhance hydrogen production while limiting the amount of catalyst coking. For Catalyst 1 , the highest water mole fraction tested, 0.5, resulted in increased hydrogen yield as illustrated in Figure 27. At these operating parameters, (oxygen mole fraction 0.1 and water mole fraction 0.5 ), the hydrogen yield was approximately 20\% greater than the oxygen-only tests with Catalyst 1.

Tests with Catalysts 2 and 3 did not yield increased hydrogen production with the higher mole fraction of water as illustrated in Figures 28 and 29. It is anticipated that at lower temperatures, the water-gas shift reaction would allow for additional hydrogen production with increased mole fraction of water.

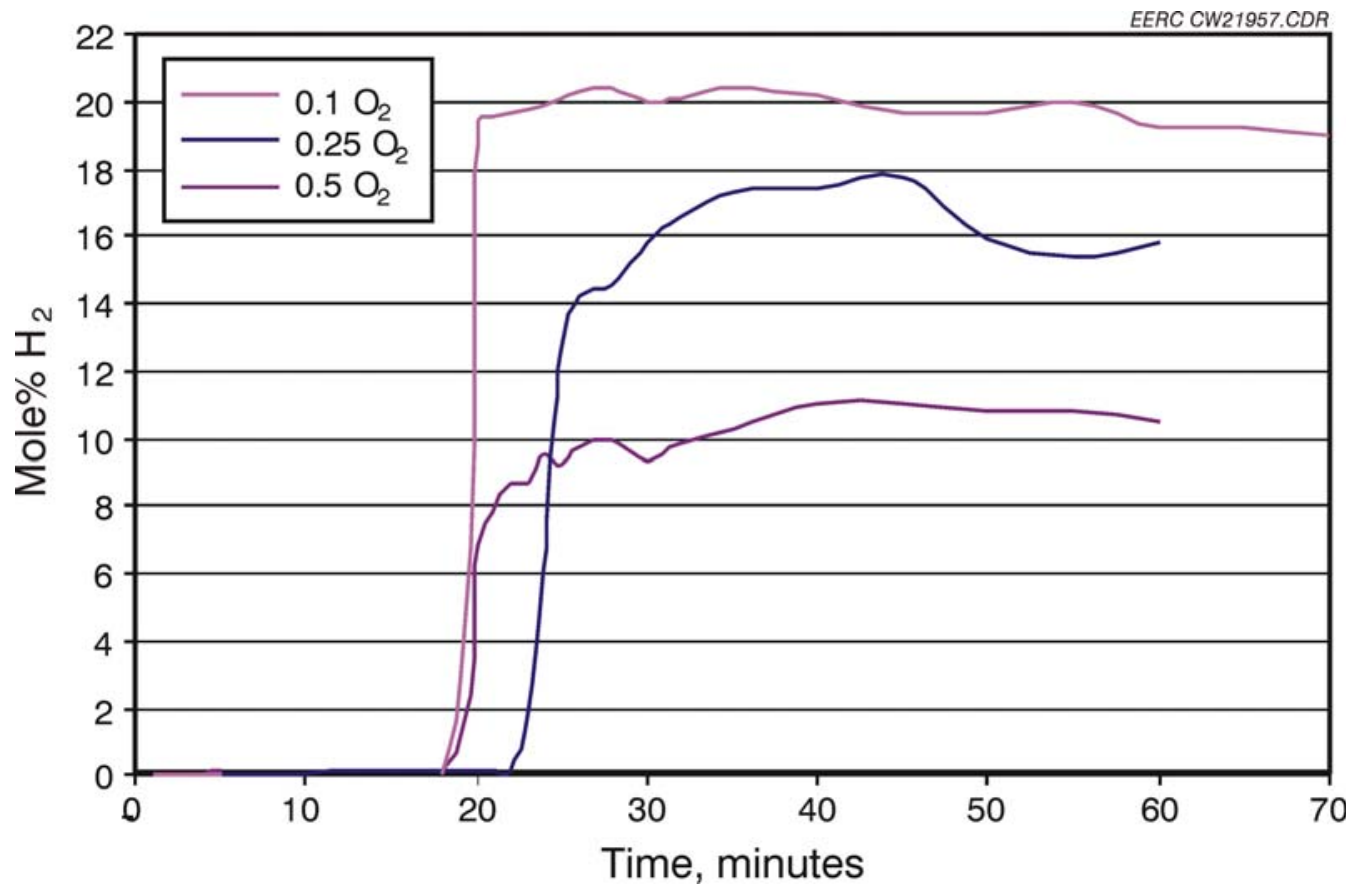

Figure 24. Effect of partial oxidation on hydrogen production for Catalyst 1, no water addition. 


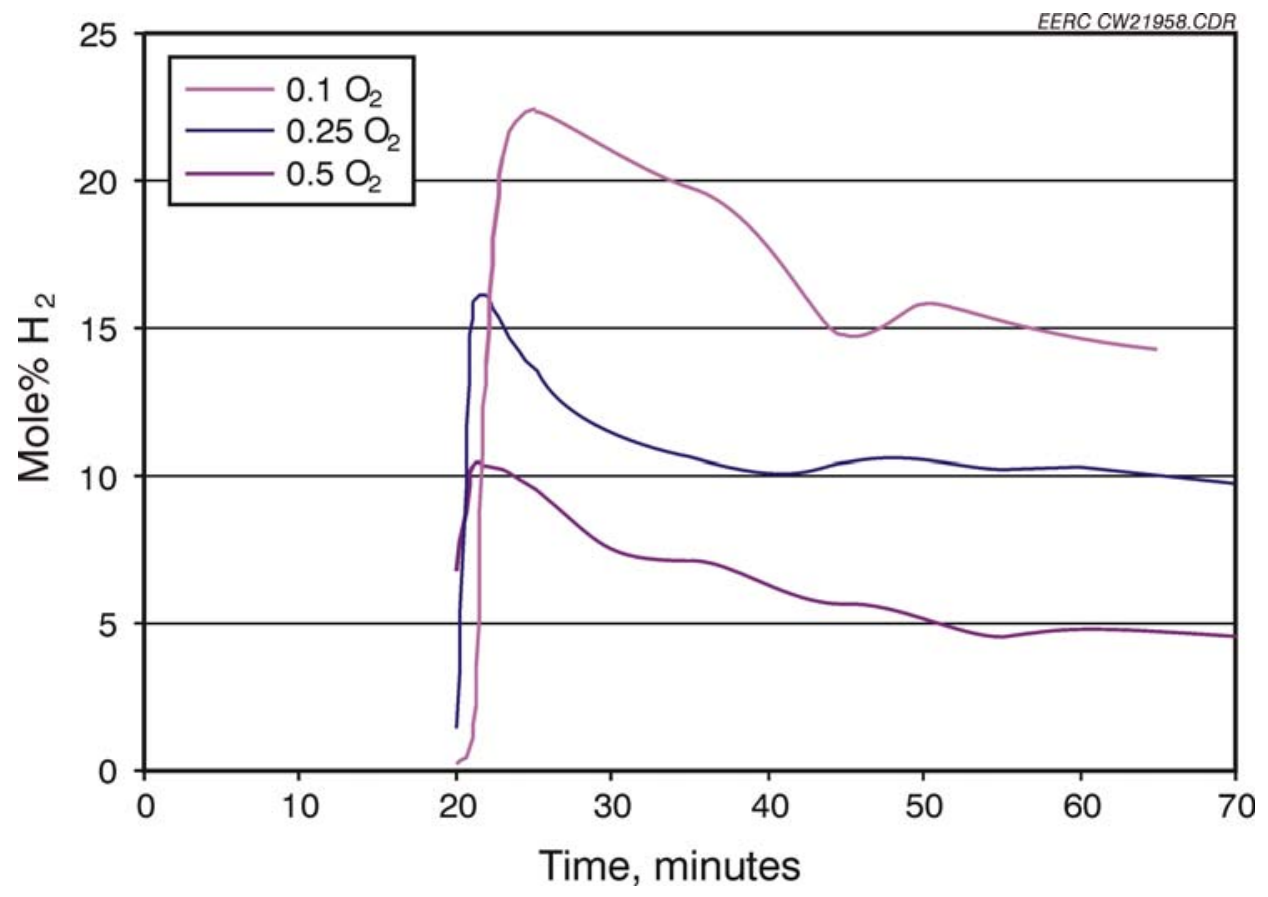

Figure 25. Effect of partial oxidation on hydrogen production for Catalyst 2, no water addition.

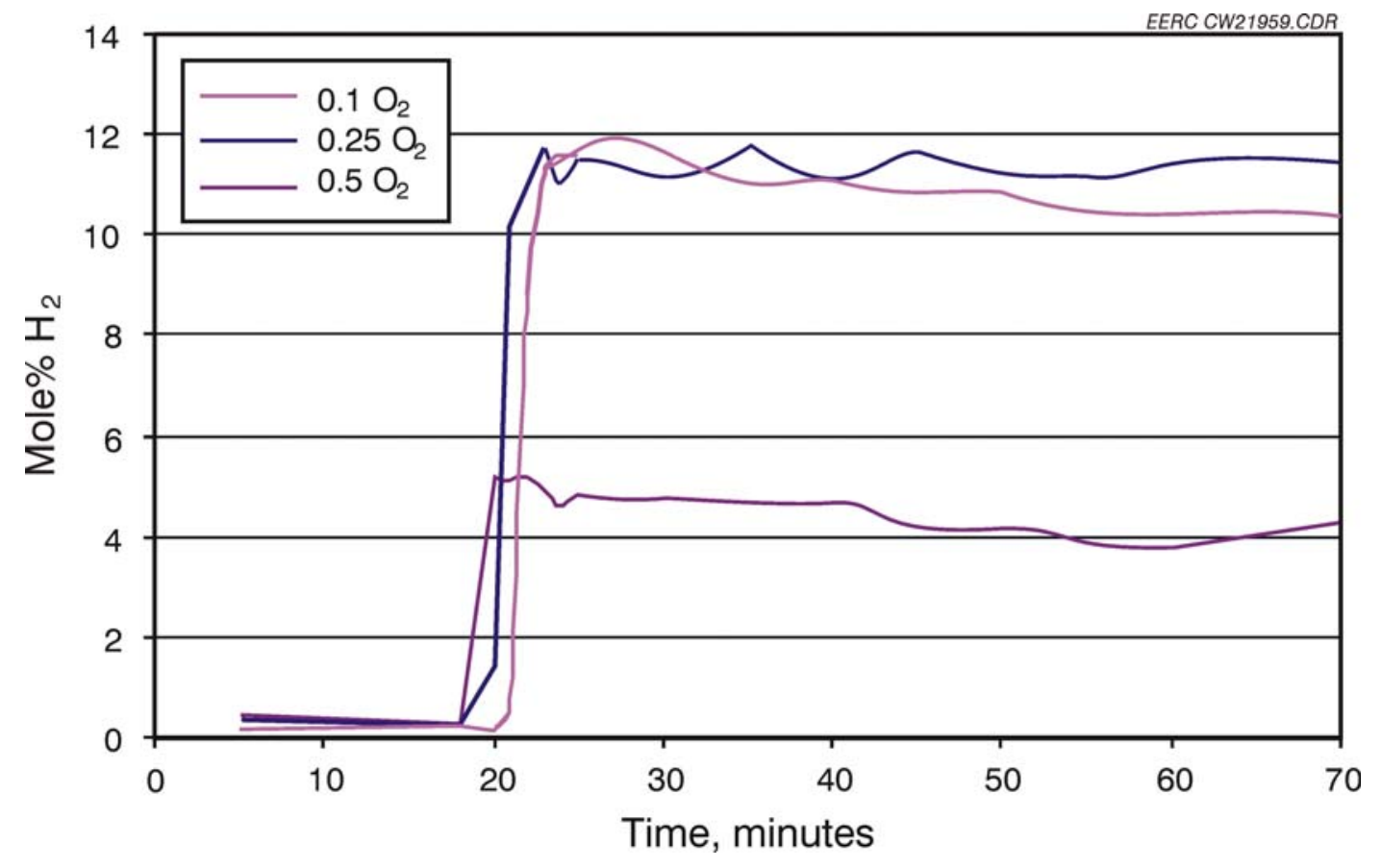

Figure 26. Effect of partial oxidation on hydrogen production for Catalyst 3, no water addition. 


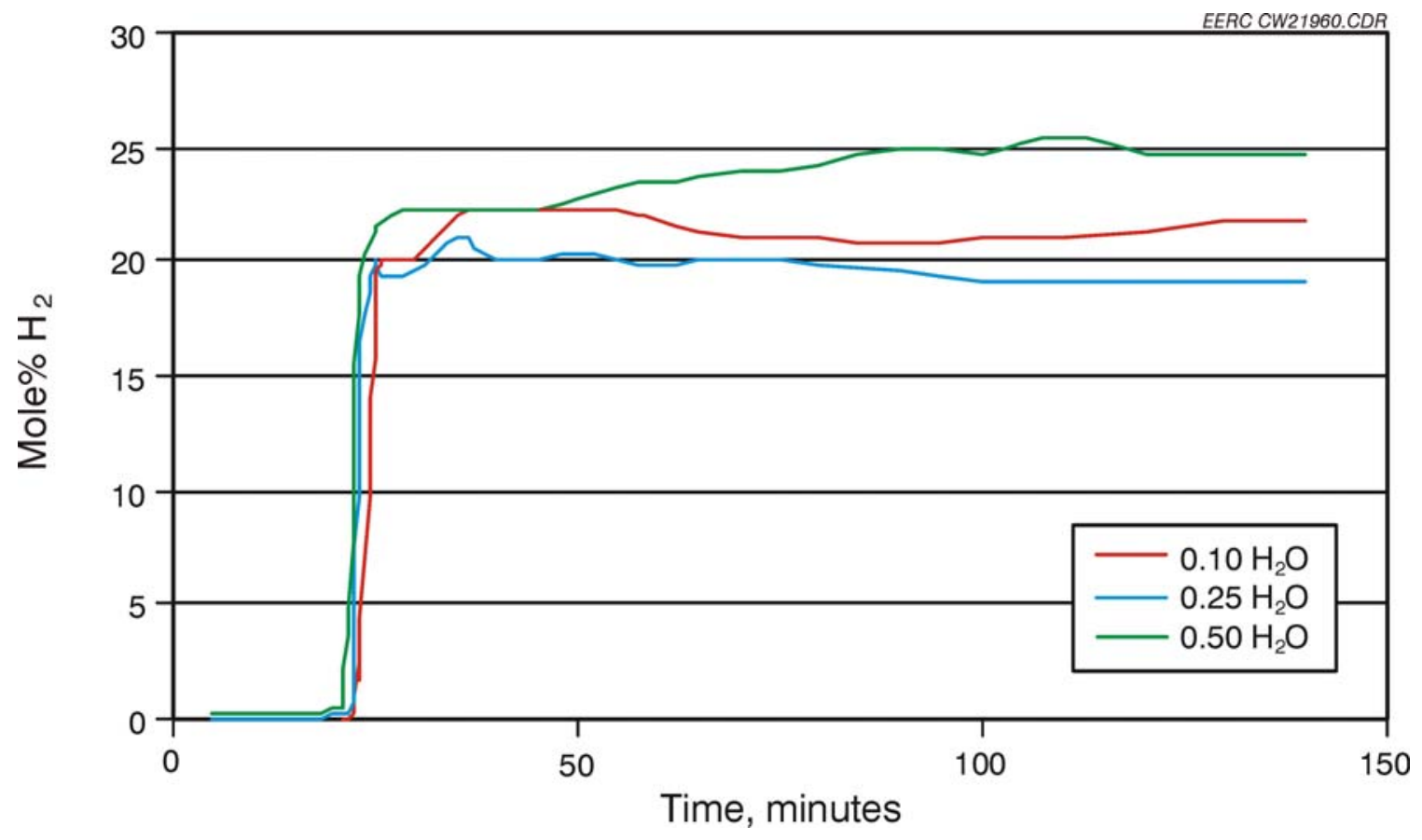

Figure 27. Comparison of water addition rates on hydrogen production, Catalyst 1.

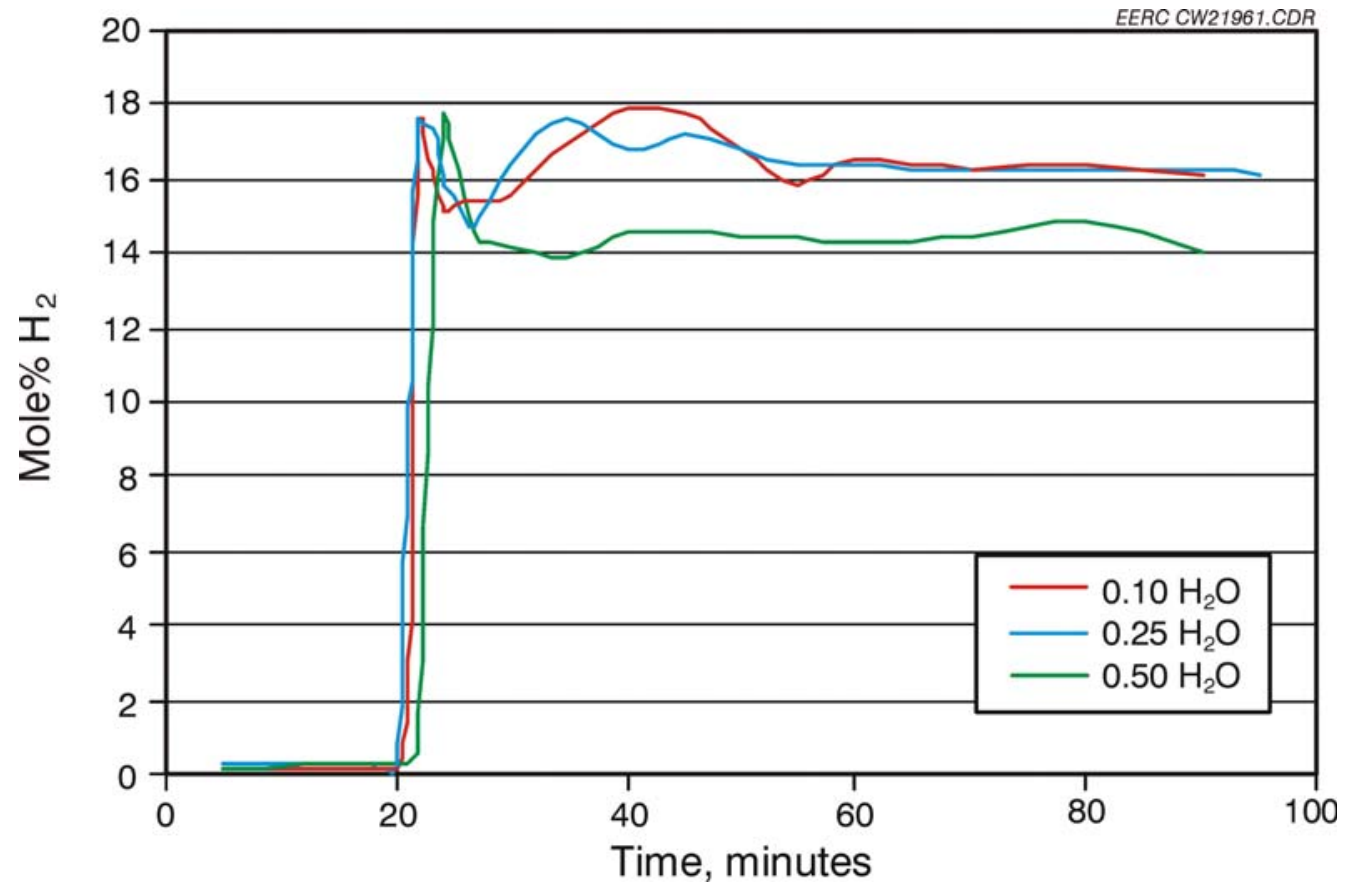

Figure 28. Comparison of water addition rates on hydrogen production, Catalyst 2. 


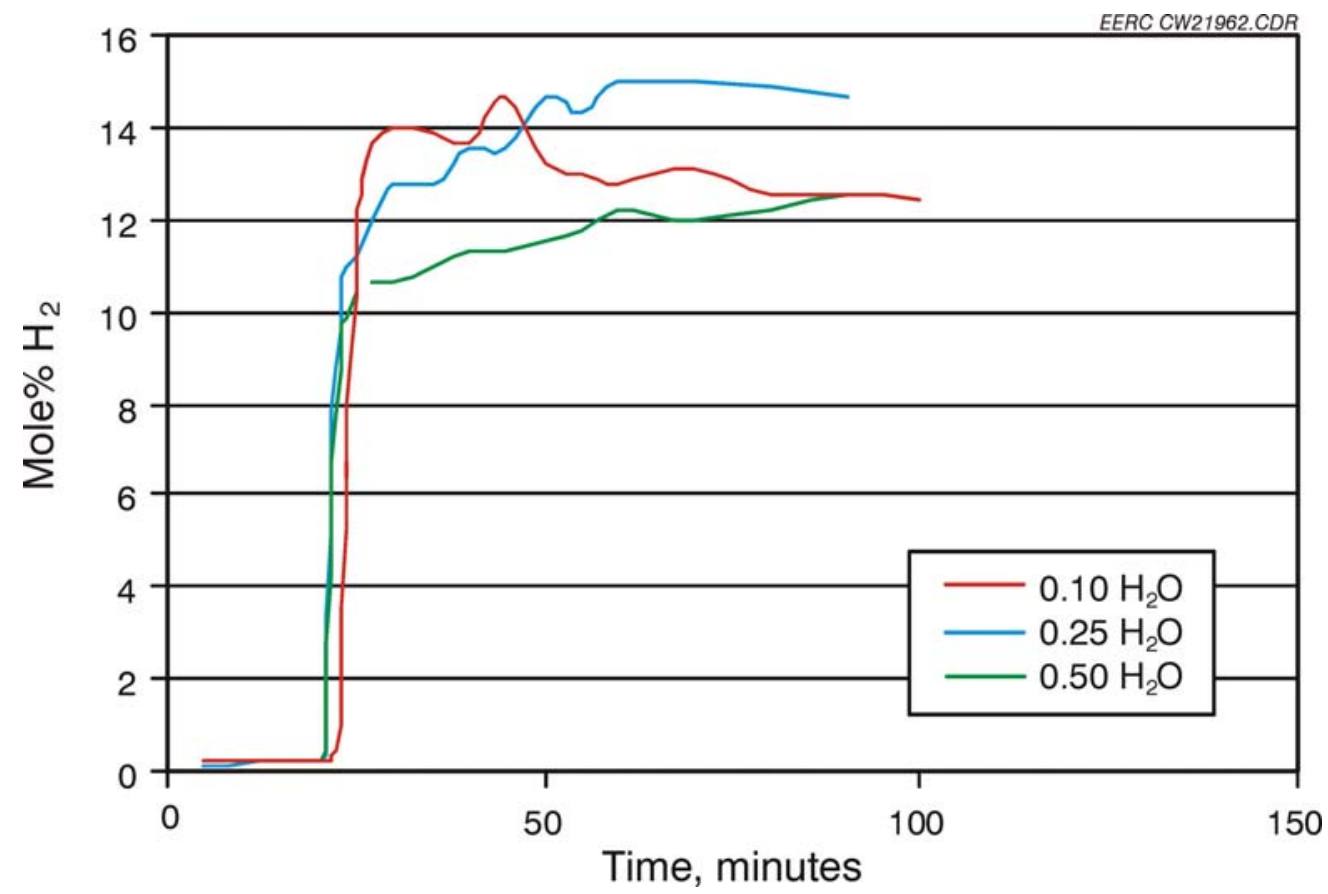

Figure 29. Comparison of water addition rates on hydrogen production, Catalyst 3.

The second criteria for evaluating the effect of water addition, as stated previously, was catalyst coking. Tests of all three catalysts illustrated a decrease in coking with the higher mole fraction of water; however, the greatest effect occurred with Catalyst 1. Graphs illustrating the percent weight change of catalyst with time for each of the three catalysts are presented in Figures 30-32. Catalyst 1, consistent with providing the highest hydrogen yield, demonstrated the greatest amount of catalyst coking, especially at the lower water fraction. However, the addition of water up to a mole fraction of 0.5 substantially reduced coking and, therefore, demonstrated the most effective combination of the parameters tested to increase hydrogen yield and minimize catalyst coking. It should be noted that increasing water or oxygen would likely reduce carbon deposition further; however, additional research would be necessary to optimize the system. The purpose of the test matrix in this study was to demonstrate the trend while keeping the feedstock flow rate to a minimum.

The tests for evaluating the effect of denaturant and temperature on hydrogen production were carried out using an oxygen in air-to-fuel mole ratio of 0.1 and a water-to-fuel mole ratio of 0.5 , which had been determined to give the greatest hydrogen yield in the previous tests. As shown in Tables 18 and 19, ethanol denatured with 5\% methanol resulted in the highest $\mathrm{H}_{2}$ and $\mathrm{CO}$ yields for both Catalysts 1 and 2 . The results were very similar when a denaturant of only $3 \%$ methanol was used with Catalyst 1 (Table 18 and Figure 33). Reforming E95/MeOH5 over Catalyst 1 resulted in $25 \%$ more $\mathrm{H}_{2}$ than over Catalyst 2 but only $11 \%$ more $\mathrm{CO}$ and $\mathrm{CO}_{2}$. However, reforming over Catalyst 2 (Table 19) resulted in $17 \%$ more $\mathrm{CH}_{4}$ than over Catalyst 1 , suggesting that Catalyst 2 may promote increased methanation over that of Catalyst 1. 


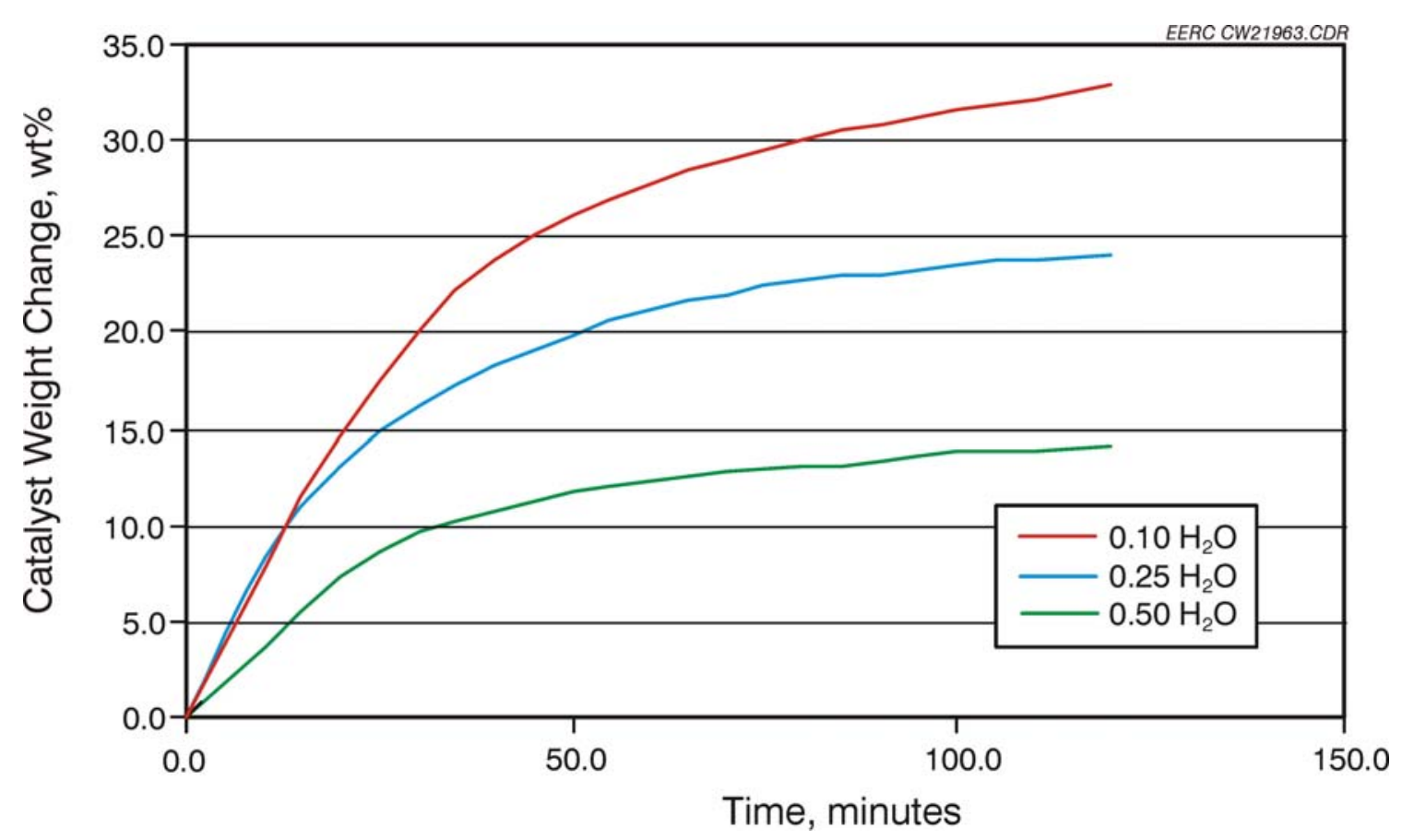

Figure 30. Coking rate for Catalyst 1 at varying water addition rates.

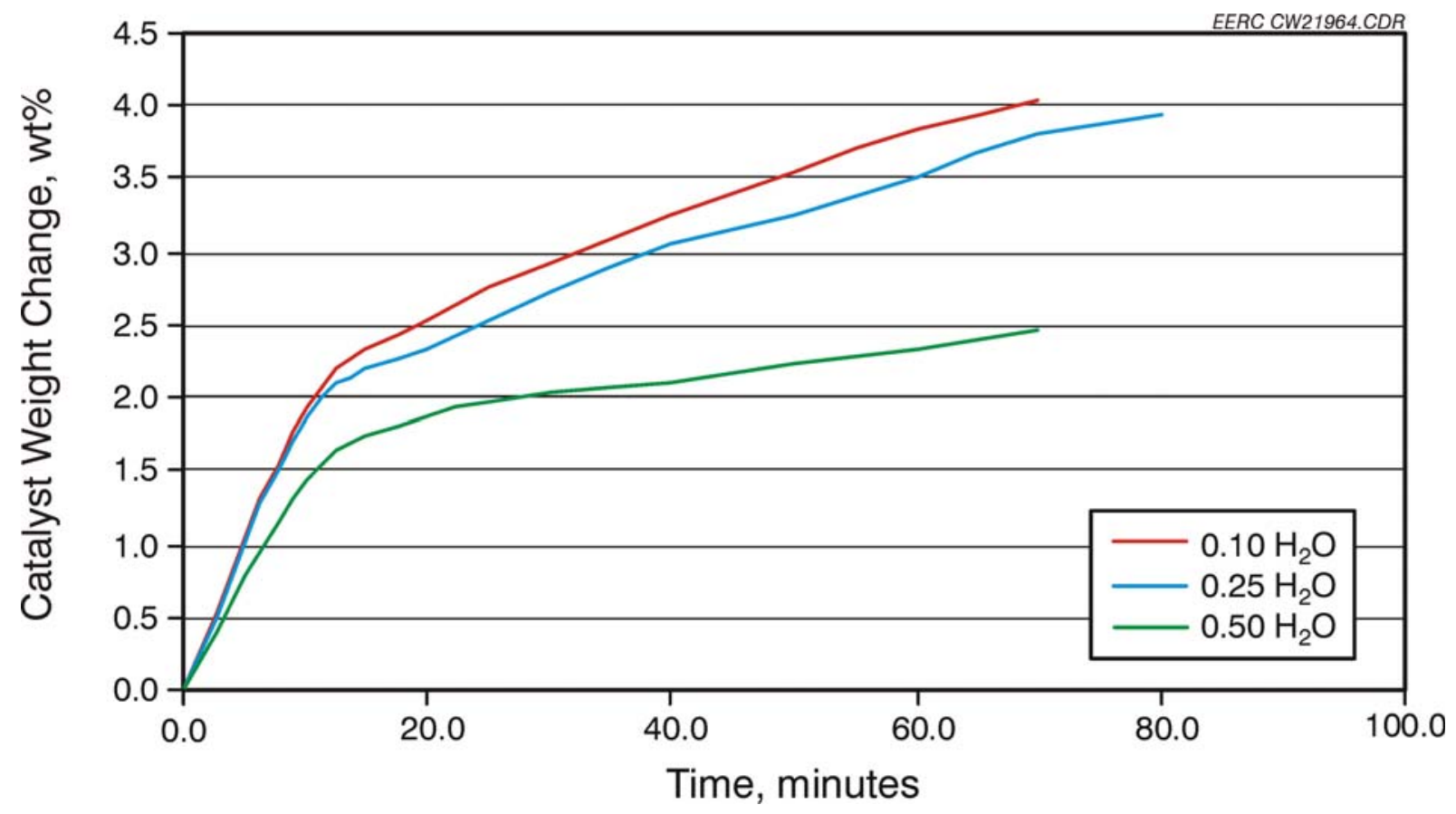

Figure 31. Coking rate for Catalyst 2 at varying water addition rates. 


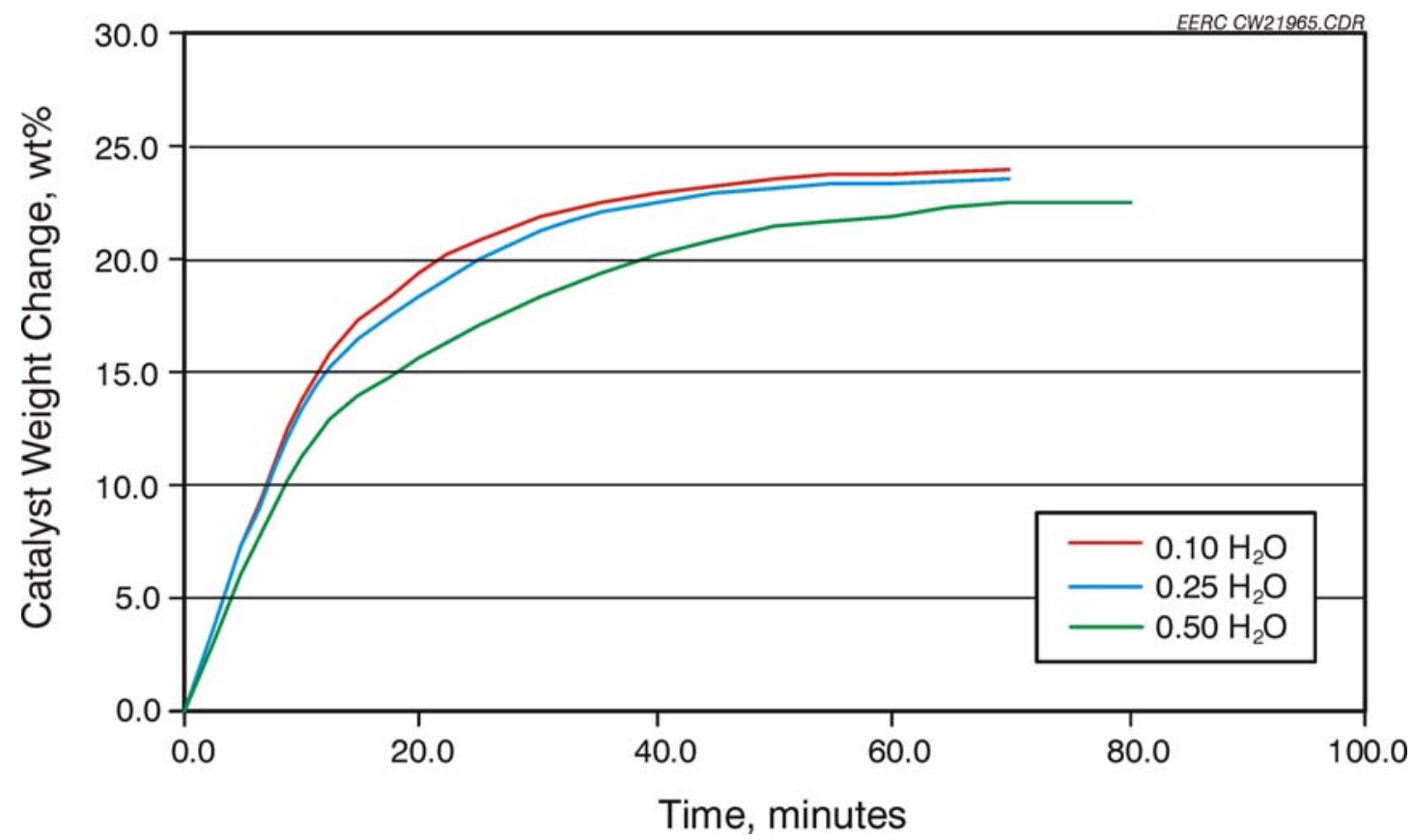

Figure 32. Coking rate for Catalyst 3 at varying water addition rates.

Table 18. Average Product Gas Composition under Catalyst 1

\begin{tabular}{lcccccc}
\hline \multicolumn{1}{c}{ mole $\%$} & $\mathrm{CO}$ & $\mathrm{CO}_{2}$ & $\mathrm{CH}_{4}$ & $\mathrm{O}_{2}$ & $\mathrm{H}_{2}$ & Balance $^{1}$ \\
\hline MeOH5 & 16.78 & 1.32 & 10.10 & 1.67 & 20.03 & 50.10 \\
MeOH3 & 15.96 & 1.30 & 8.98 & 2.39 & 20.20 & 51.17 \\
RUG15 & 12.18 & 0.73 & 11.87 & 1.18 & 10.17 & 63.87 \\
RUG5 & 7.14 & 0.26 & 5.86 & 0.28 & 7.71 & 78.75 \\
NGL5 & 13.27 & 1.06 & 10.30 & 1.87 & 12.56 & 60.94 \\
\hline
\end{tabular}

${ }^{1}$ The balance of exit gas consisted primarily of nitrogen with trace amounts of miscellaneous compounds.

Table 19. Average Product Gas Composition under Catalyst 2

\begin{tabular}{lcccccc}
\hline \multicolumn{1}{c}{ mole \% } & $\mathrm{CO}$ & $\mathrm{CO}_{2}$ & $\mathrm{CH}_{4}$ & $\mathrm{O}_{2}$ & $\mathrm{H}_{2}$ & Balance $^{1}$ \\
\hline MeOH5 & 14.91 & 1.18 & 11.83 & 2.48 & 15.2 & 54.40 \\
RUG15 & 11.22 & 1.22 & 12.29 & 1.05 & 8.99 & 65.23 \\
RUG5 & 7.92 & 0.25 & 8.06 & 0.30 & 7.94 & 75.53 \\
NGL5 & 12.35 & 1.29 & 11.88 & 1.36 & 10.43 & 62.69 \\
\hline
\end{tabular}

${ }^{1}$ The balance of exit gas consisted primarily of nitrogen with trace amounts of miscellaneous compounds.

Catalytic reforming of the E85/RUG15 over both Catalysts 1 and 2 resulted in higher concentrations of all product gases than did E95/RUG5. Graphs illustrating the percent weight change of catalyst with time as a result of catalyst coking are presented in Figures 34 and 35. Catalyst 1, while providing the highest hydrogen yield, resulted in greater catalyst coking. The high levels of $\mathrm{CO}$ and low $\mathrm{CO}_{2}$ shows that water-gas shift was not promoted by either catalyst at 


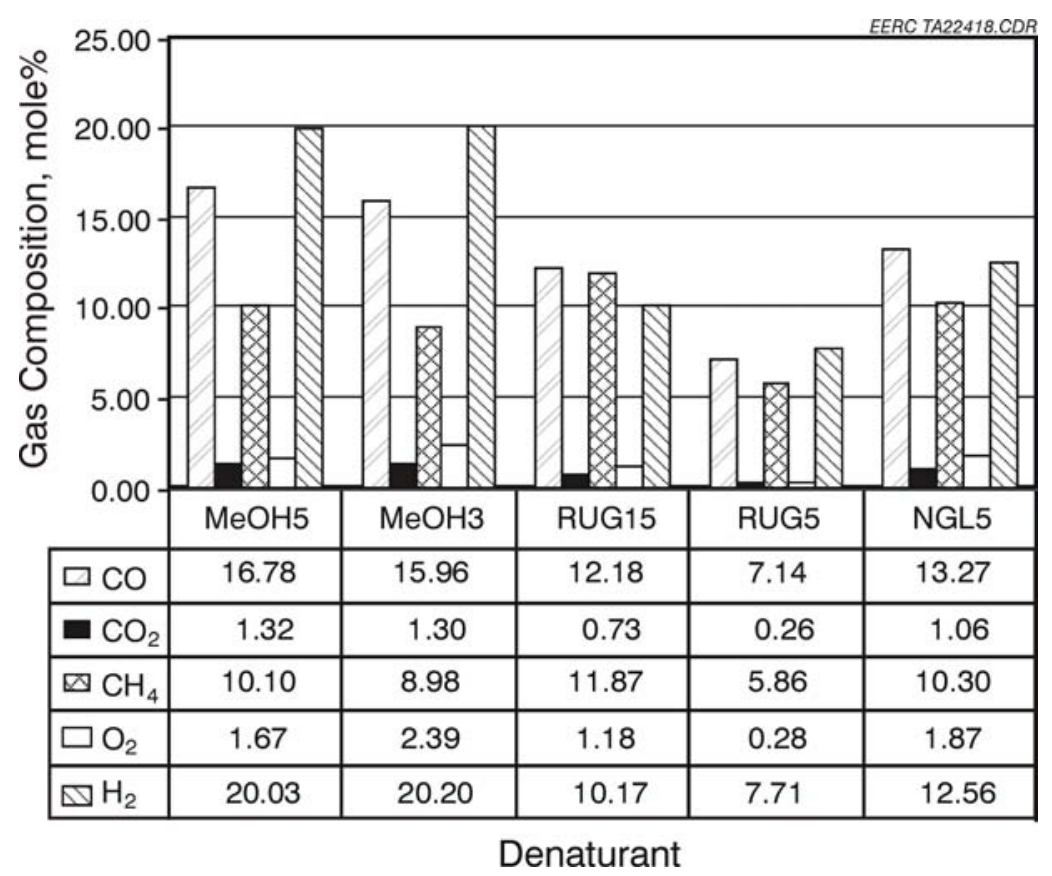

Figure 33. Product gas composition for Catalyst 1.

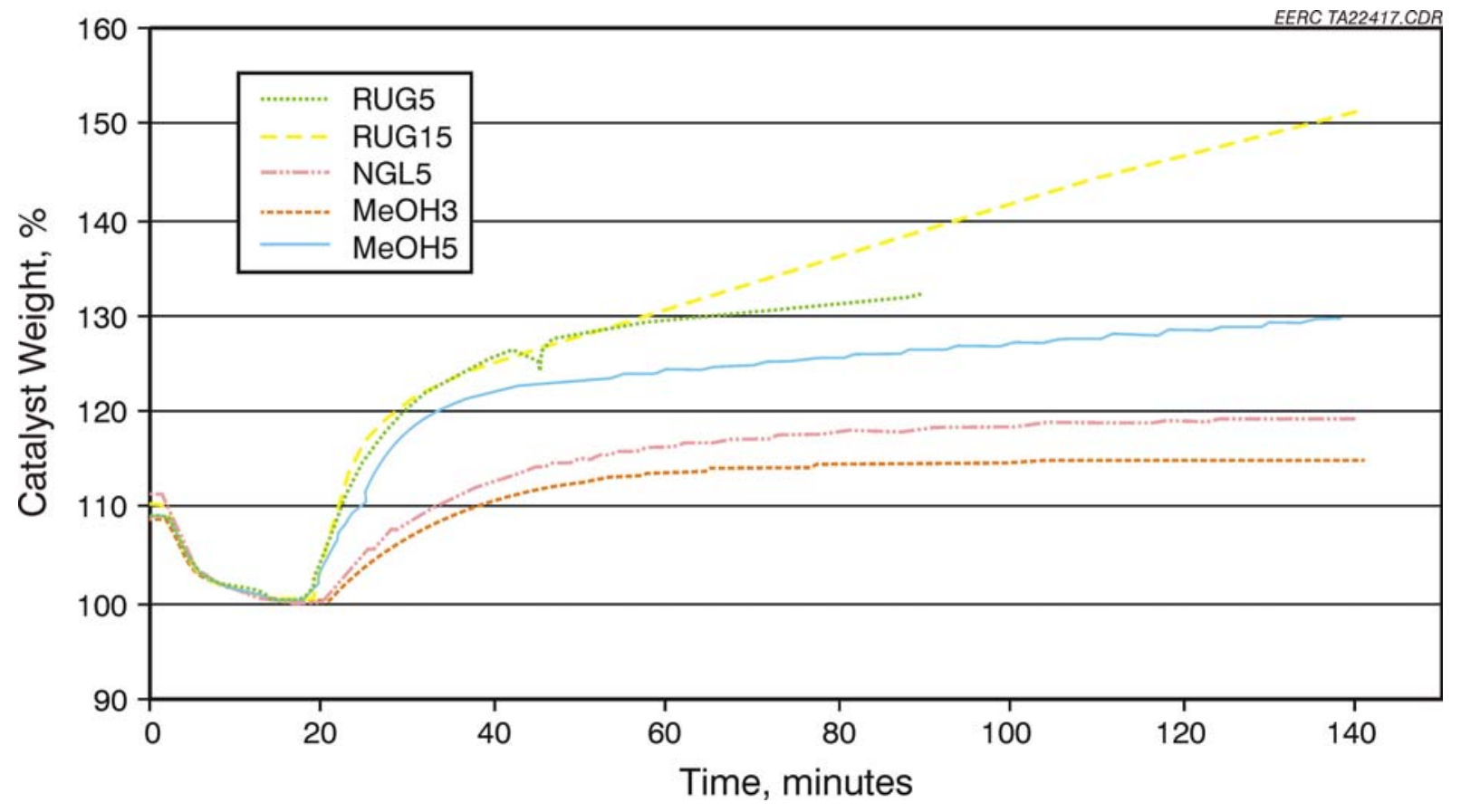

Figure 34. Comparison of coking rates for various denaturants, Catalyst 1. 


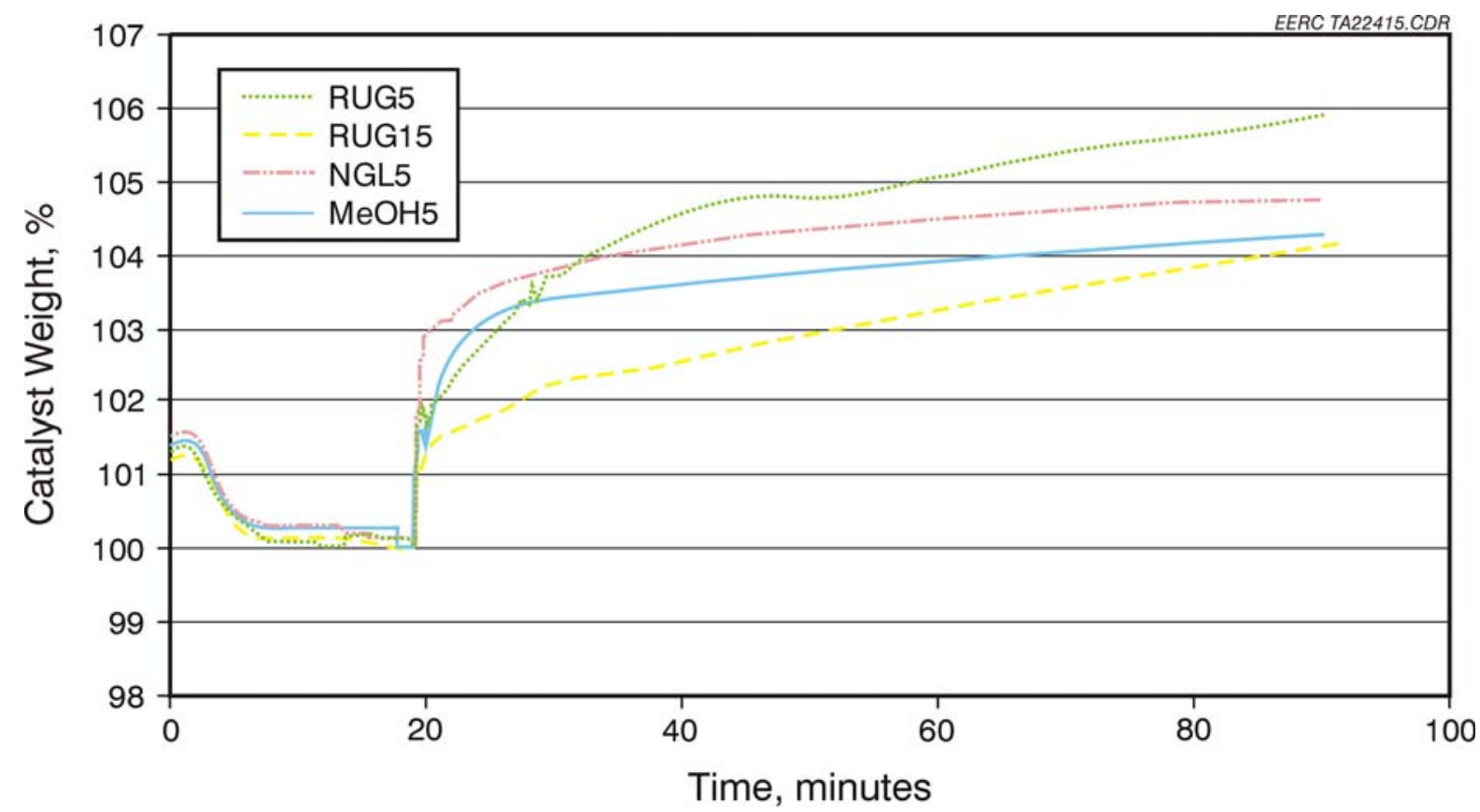

Figure 35. Comparison of coking rates for various denaturants, Catalyst 2.

these conditions, a result that must be addressed on a commercial system. This study did show that, relative to hydrogen production, Catalyst 1 provided the most effective results. The greatest amount of coking occurred when regular unleaded gasoline (RUG5 and RUG15) was used as a denaturant and can be attributed to the absence of oxygen and the large hydrocarbon molecular structure. The methanol-denatured fuel was low-coking and provided the highest hydrogen yield, suggesting that it was well suited to reforming with the catalysts tested.

The effect of increased temperature on reforming under $\mathrm{CPOX}$ conditions included an increase in catalyst coking and higher $\mathrm{H}_{2}, \mathrm{CO}$, and $\mathrm{CH}_{4}$ production up to the highest temperature tested of $755^{\circ} \mathrm{C}$ (Figure 36). Product gas concentrations increased across the temperature range, with the exception of $\mathrm{CO}_{2}$ and $\mathrm{O}_{2}$ which decreased slightly as temperature increased. Within these temperature ranges as well as water and oxygen mole fractions, an increase in fuel conversion was observed; however, there was a corresponding reduction in the water-gas shift reaction.

\section{Conclusions}

Preliminary testing conducted to evaluate the relative impact of catalyst as well as air and water stoichiometry on cPOX reforming of ethanol showed that the greatest hydrogen yield and least catalyst coking occurred with Catalyst 1 at an oxygen-fuel mole fraction of 0.1 and a waterfuel mole fraction of 0.5. At these conditions, hydrogen production was measured as high as 25 mole percent (Figure 27), and catalyst coking, as measured by percent weight gain, was limited to less than $15 \%$ over a period of 120 minutes (Figure 30). 


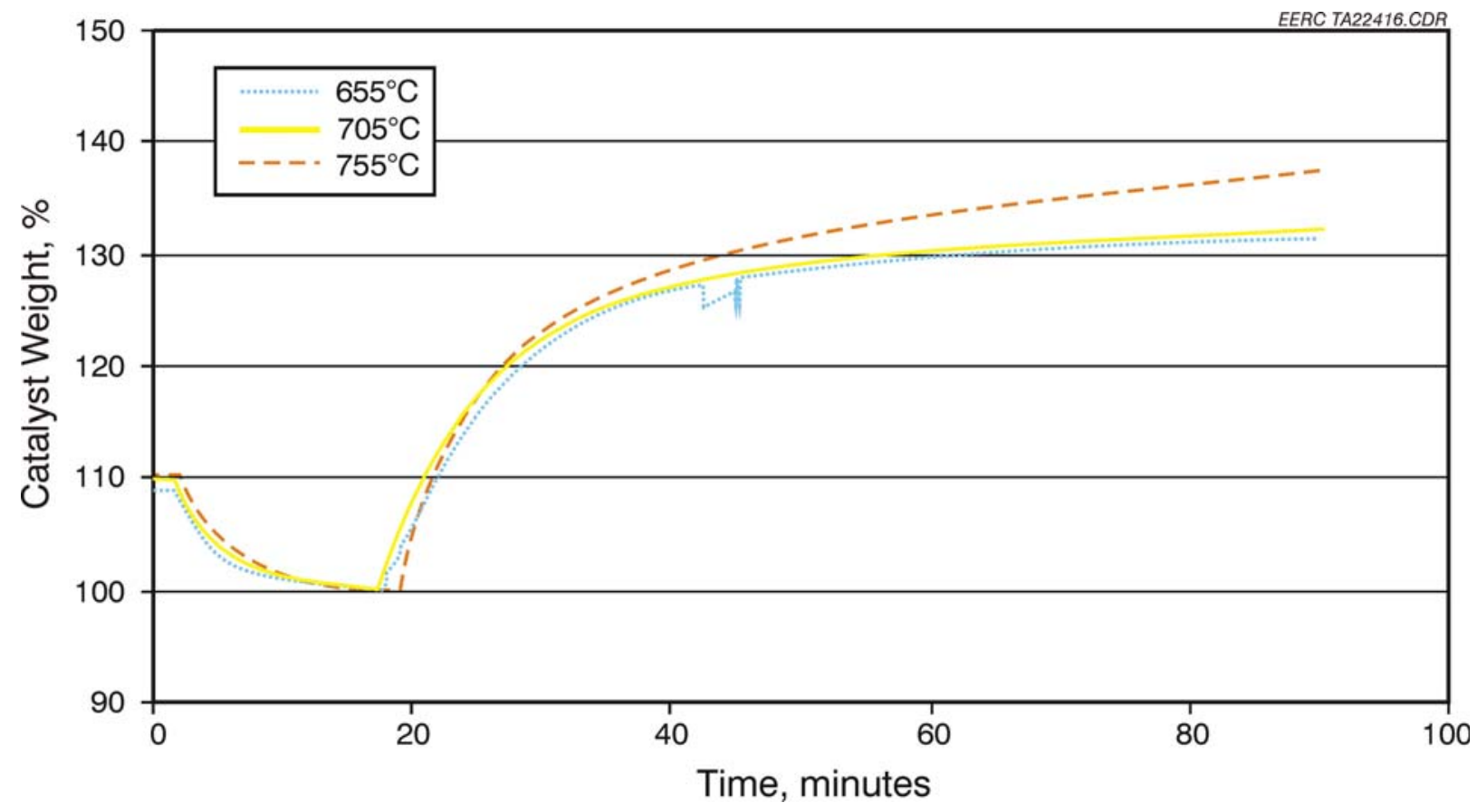

Figure 36. Comparison of the coking rate versus temperature, Catalyst 1.

Using these parameters, it was determined that ethanol denatured with methanol provides higher $\mathrm{H}_{2}$ yields than ethanol denatured with RUG or NGL. In addition, use of the methanol denaturant resulted in less catalyst coking than the other denaturants, which translates to a higher revenue stream while reducing costs of operation by extending catalyst life. While no attempt was made to increase $\mathrm{H}_{2}$ through catalytic water-gas shift, it is clear that the high $\mathrm{CO}$ concentration in all of the observed product streams could be used to recover additional $\mathrm{H}_{2}$.

Increasing the operating temperature of the bench scale cPOX system from $655^{\circ}$ to $755^{\circ} \mathrm{C}$ resulted in a doubling in $\mathrm{H}_{2}$ and $\mathrm{CH}_{4}$ concentration and nearly doubling the $\mathrm{CO}$ concentration. However, at temperatures above approximately $705^{\circ} \mathrm{C}$, coking of the catalyst surface increased as the temperature increased from $705^{\circ}$ to $755^{\circ} \mathrm{C}$. Within the limits of this study, $705^{\circ} \mathrm{C}$ appeared to be the upper temperature for maximizing catalyst life and overall system efficiency. However, additional study and optimization of operational parameters including air and water addition rates would substantially improve fuel conversion and limit catalyst coking for applicability to large scale applications.

\section{SUBTASK 2.2 - THE USE OF REGIONALLY AVAILABLE WASTE OILS AND AN IMPROVED CATALYST IN THE PREPARATION OF BIODIESEL FUEL}

A confidential report of Subtask 2.2 is available in Appendix B. 


\section{SUBTASK 2.3 - ASSESSMENT OF THE USE OF ETHANOL FUELS IN TWO-CYCLE ENGINES}

\section{Introduction}

The U.S. Environmental Protection Agency (EPA) in September of this year issued proposed regulations limiting the amount of carbon monoxide (CO) and hydrocarbons emitted from snowmobiles, all-terrain vehicles (ATVs), and off-road vehicles. Additionally, the National Park Service is currently considering a plan to ban snowmobiles from national parks altogether. In conversations with the president of the International Snowmobile Manufacturers Association (ISMA), the president stated that the regulations as proposed will, at the very least, cause a decrease in snowmobile sales of $40 \%$ and cause the decline from four manufacturers to two. At issue for the National Park Service is the amount of emissions emitted by these snowmobiles in the parks. On average, 65,000 snowmobilers visit Yellowstone National Park (YNP) yearly, with a peak of 143,000 in the mid-1990s. The majority of snowmobiles are powered by two-stroke engines. Some of the emissions from these snowmobiles are deposited directly onto the snowpack. This snowpack pollution translates directly into pollution of the waters as the snow melts. The components of snowpack pollution from snowmobile emissions can include toxic compounds such as MTBE (methyl tertiary-butyl ether), a fuel additive. MTBE is a known animal carcinogen and a suspected human carcinogen. The replacement of MTBE-blended fuels with ethanol-blended fuels may be one way to reduce the emission levels of these recreational vehicles. EPA states that reformulated gasoline (RFG) has led to significant improvements in air quality, including a $17 \%$ reduction in volatile organic compound (VOC) emissions from vehicles and a 30\% reduction in toxic emissions. Furthermore, according to EPA, ambient monitoring data from the first year of the RFG program (1995) also showed strong signs that RFG is working. For example, detection of benzene (one of the air toxics controlled through RFG and a known human carcinogen) declined dramatically, with a median reduction of $38 \%$ from the previous year. The air quality benefits from purer forms of ethanol can also be substantial. Compared to gasoline, use of E85 can result in a 30\%-50\% reduction in ozone-forming emissions. While the use of ethanol also leads to increased emission of acetaldehyde, a toxic air pollutant, as defined by the Clean Air Act, these emissions can be controlled through the use of advanced catalytic converters. However, the need for oxygenates such as ethanol in RFG has been questioned. Although oxygenates lead to lower emissions of VOCs and CO, they may lead to higher emissions of nitrogen oxides $\left(\mathrm{NO}_{\mathrm{x}}\right)$. The cost of catalytic converters and the reduced performance of redesigned engines are highly disputed, and these issues require further investigation.

\section{Experimental}

The objective of this task is a paper study of the increasing need to use clean, alternative fuels (specifically ethanol) in two-stroke engines and the possible benefits that could be achieved by this. 


\section{Results and Discussion}

\section{Ethanol}

Ethanol is a clear, colorless liquid also known as ethyl alcohol or grain alcohol. It is currently blended with gasoline in various amounts to produce gasohol. These ratios vary from around 10\% ethanol (E10) to 85\% ethanol (E85). It is generally considered a fuel additive that reduces the amount of harmful and toxic emissions in high-traffic areas. Used primarily during winter conditions, gasohol, otherwise known as an oxygenated fuel, has effectively reduced CO emissions in many large cities in order to meet growing state and federal clean air regulations. Ethanol can also replace MTBE, an oxygenate additive to fuels that has been banned in many states because of the environmental hazards that exist while MTBE is stored in underground fuel tanks. Because ethanol is not considered a toxic pollutant, it is much safer to store, transport, and transfer. It is biodegradable and water-soluble, and ethanol spills are usually harmless.

Ethanol can be produced from a variety of starchy crops such as corn, wheat, potatoes, sugar beets, paper and wood wastes, and other agriculturally based and organic substances. This makes ethanol a preferable fuel alternative. A $10 \%$ ethanol blend fuel is warranted for use in internal combustion engines by virtually all engine manufacturers. All of the major automobile manufacturers now offer a vehicle that is specifically designed to burn E85. The production of ethanol has provided a significant boost to rural and agricultural economies. These agricultural communities have historically experienced financial and economic difficulties and will benefit tremendously from increased ethanol demands. In 2001, ethanol produced in Iowa generated $\$ 1.7$ billion in economic activity and added approximately $\$ 730$ million to Iowa's corn crop (16).

Ethanol is a renewable resource, and it is easy to understand the advantages of increasing its production and utilization. Along with reducing harmful emissions and improving the U.S. economy, it will also decrease America's dependence on foreign oil imports.

\section{Two-Stroke Engines and Emissions}

Because of the increased amount of two-stroke engine sales and the growing concerns about air quality and environmental pollution, it has become necessary to study the effects of these engines and their emissions. Two-stroke engines have always been associated with high emission outputs. These engines are found in off-road vehicles (snowmobiles, ATVs, and personal watercrafts), outboard marine motors, lawnmowers, chainsaws, weed trimmers, and other products. Snowmobiles and personal watercraft, in particular, have come under more scrutiny because of their growing presence in America's federally protected and regulated national parks. These national park debates over snowmobile and personal watercraft use in these areas have sparked passionate and sometimes violent arguments. Increasing federal air and water quality regulations have led snowmobile and personal watercraft manufacturers to investigate ways to reduce their emissions. Two-stroke engines that burn gasoline, or all gasoline engines for that matter, produce many different by-products or potentially hazardous air pollutants. Conventional two-stroke engines were designed to provide power at low cost (chainsaws and lawnmowers, for example), and these engines typically expel a large percentage 
of unburned fuel or hydrocarbons (HCs). Some of these emissions are carbon monoxide (CO), carbon dioxide $\left(\mathrm{CO}_{2}\right), \mathrm{NO}_{x}$, particulate matter (PM), and unburned HCs. HCs are speciated or analyzed and classified into many (more than 200) different exhaust species such as aldehydes, ketones, methane, propane, toluene, ether, etc. Some of these organic gases are classified as toxic species (benzene, butadiene, formaldehyde, and acetaldehyde) by EPA and regulated because of their role in ozone formation.

Efforts to reduce the emissions from off-road vehicles have led to technical innovations in two-stroke engine designs in many new models (17). These efforts also resulted in the introduction of four-stroke engines in snowmobiles, personal watercraft, and ATVs. There are several drawbacks associated with the introduction of four-stroke engines. A large amount of research and development, engineering resources, and vehicle design modifications have been necessary to accomplish the production of the new models. Four-stroke engines are much heavier, more complex, and more expensive. The cost per horsepower for two-cycle engines was estimated in 1991 to be $70 \%$ of an equivalent four-stroke engine (17). Four-stroke engines possess more moving parts and components, and this increases their possibility of mechanical failure. Although four-stroke engines are considered more efficient and environmentally friendly, they produce much less horsepower for their weight, and many consumers are reluctant to purchase them. Two-stroke engines have long been known for their simple design and their ability to produce the horsepower and torque that is so sought after by off-road vehicle enthusiasts. This creates the need to explore ways to reduce the hazardous air pollution that they produce. Technological achievements such as direct cylinder fuel injection, engine control modules, fuel atomizing carburetors, external scavenging systems, and exhaust catalysts have led to significant emission reductions. However, many off-road vehicles do not possess these technologies. Many smaller-engine applications are not candidates for four-stroke engines, and the large amount of two-stroke engines that currently exist is reason to investigate ways to reduce, through fuel selection, the emissions that they produce.

\section{Yellowstone National Park}

In 1995, the YNP debate over snowmobile usage became heated. The large numbers of snowmobiles using this well-preserved national park were presumably the cause of high levels of toxic pollutants. This is when the Montana Department of Environmental Quality (DEQ) decided to seek answers and provide possible solutions to this problem. Prior studies of emissions in EPA-regulated areas (attainment areas) had shown that the use of a $10 \%$ blend of ethanol or gasohol produced significant reductions of $\mathrm{CO}$ and HCs. However, these studies were done in large cities and involved transportation vehicles with four-stroke engines. Missoula, Montana, had reduced its CO levels by $24.3 \%$ with the use of E10. This enabled the DEQ to speculate on the probability of reducing the amount of CO levels in greater YNP with the use of oxygenated fuels in all of its vehicles. The high number of snowmobiles in the park made it reasonable to test the theory on snowmobiles. In a study funded by the International Snowmobile Manufacturers Association, DOE, the Wyoming Energy Office, the National Park Service, and several other groups, a two-part program was developed in order to evaluate the emission-reducing benefits of using ethanol-blended fuels in snowmobiles. In order to complete these tests accurately and produce credible results, a standard test procedure needed to be developed. 


\section{Testing Methods}

Before the use of ethanol in snowmobiles could be tested for its ability to reduce emissions, a standardized test method had to be developed. The Montana DEQ and South Western Research Institute (SWRI) of San Antonio, Texas, worked together to develop a fivemode snowmobile test cycle. This is the industry-approved test procedure and accepted standard used by snowmobile manufacturers and EPA. Because of the large number of variables involved with engine designs and characteristics, environmental operating conditions, and snowmobile driving styles, a controlled testing procedure that most accurately simulates average snowmobile operation was needed. This was a formidable task, and some control issues were inevitable. The five modes that are incorporated into the test procedure were designed to simulate five different driving styles of on- and off-road snowmobile operation. In order to best duplicate real-time snowmobile operation, real-time data were collected from instrumented snowmobiles during actual operation. The fact that snowmobile emissions are directly related to engine speeds, track loading, and drivetrain power losses necessitates a highly controlled testing procedure. Test engines are mounted on a bed plate and connected to a dynamometer by a coupler. The dynamometer is a close-looped, computer-controlled system that senses and controls engineoperating conditions. A separate four-mode chassis test is used for more precise control and provides drivetrain and track-loading conditions. A complete snowmobile is needed for this application. Engine exhaust is transferred to a 46-cm (18-in.)-diameter dilution tunnel, and proportional bag samples are collected for $\mathrm{CO}$ and $\mathrm{CO}_{2}$ analysis and $\mathrm{HC}$ speciation. Separate samples determine $\mathrm{HC}$ and $\mathrm{NO}_{\mathrm{x}}$ levels. A portion of the exhaust gas is routed to a secondary dilution tunnel for particulate matter measurements. Tests on carbureted engines without altitude compensation can be conducted to simulate high-altitude conditions. A complete report on this testing procedure has been published in Society of Automotive Engineers (SAE) technical report 980217 (18).

In addition to laboratory testing of snowmobile engines, the Montana DEQ conducted field demonstration tests along with the analysis of permanent glacier snowpack samples as a way to monitor the status of emission outputs in YNP.

\section{Lab Test Results}

The ISMA provided the DEQ with two engines, and they were tested by the SWRI using a $10 \%$ ethanol-blended fuel. These test results indicated substantial emission benefit, and the test data for one engine showed 16\% fewer HCs, 9\% less CO, and 24\% less PM than with gasoline. As a result of this project, the DEQ recommended that only ethanol-blended fuel (E10) be used in YNP. "The Park Service will use 10\% ethanol blend and synthetic biodegradable lube oils in all its snowmobiles in YNP. The use of $10 \%$ blend by rental operators and the park service will reduce snowmobile CO emissions by $9 \%-38 \%$ and PM by $24 \%-55 \%$ compared to previous years. Use of $10 \%$ ethanol blend and other oxygenated fuels reduces emissions of most harmful pollutants in both snowmobiles and snow coaches.” They estimated that a fleet of about "225 snowmobiles using 700,000 gallons of gasohol would reduce hydrocarbon emissions in Montana and the Park by about 14.8 tons, carbon monoxide emissions by about 20.3 tons, and particulate matter by about 324 pounds (18).” 
The SAE Clean Snowmobile Challenge provides snowmobiles and engines for testing, and the SWRI performs these tests. SWRI and the DEQ decided to test a two-stroke engine from the challenge using an $85 \%$ ethanol-blended fuel. The test results showed a further reduction in emission results than in the tests using E10. E85 reduced HC emissions by $50 \%$, CO by $37 \%$, $\mathrm{CO}_{2}$ by $37 \%$, and $\mathrm{PM}$ by $58 \%$.

Although ethanol-blended fuel tended to slightly increase the $\mathrm{NO}_{\mathrm{x}}$ levels, these levels can be reduced with the use of exhaust catalysts. There are also concerns over the increase in aldehydes, and this is something that needs to be addressed further.

\section{Conclusions}

The use of ethanol-blended fuels is obviously one way to reduce emissions in two-stroke engines. The use of E10-blended fuels shows significant reductions in emissions, with E85 showing even more dramatic reductions in emissions. More engines need to be tested, and durability tests should be performed to instill confidence in consumers. Consumers need to be educated about the advantages of using E85. The combinations of technological innovations and the use of ethanol could conceivably reduce two-stroke engine emissions by significantly large amounts. It is important to remember that these results could be expected in all two-cycle engines, including snowmobiles, personal watercraft, outboard motors, motorcycles, ATVs, lawnmowers, chainsaws, weed trimmers, electrical generators, compressors, pressure washers, mopeds, and scooters. With the growing population and the amount of engines increasing every year, these emission problems will not go away. There is an estimated 2.7 million snowmobiles registered alone, and this number increases every year. Education and more testing will be needed to overcome the problems of lack of availability of E85.

\section{SUBTASK 3.1 - BENCH-SCALE DEMONSTRATION OF ESTERIFICATION BIOREFINERY ROUTES TO FUEL, SOLVENT, AND CHEMICAL INTERMEDIATES}

A confidential report of Subtask 3.1 is available in Appendix B.

\section{SUBTASK 3.2 - LACTIC ACID FERMENTATION FROM AMYLOSE HYDROLYSATE}

\section{Introduction}

Recent changes in agriculture brought about by increasing globalization of trade and a new awareness of the need to reduce U.S. dependency on foreign oil provide a real need for diverse technologies capable of producing a variety of fuel and chemical products from value-added agricultural products.

The EERC has been working to develop the dual-fermentation biorefinery (DFB) concept, which integrates the production of ethanol (yeast fermentation) and carboxylic acids (bacterial fermentation) to produce high-value organic acid esters. This allows tremendous flexibility in 
producing the respective products to optimize revenue through selective commodity production to satisfy changing market demands. DFBs could be established through the modification of existing beet sugar factories coupled with a new ethanol facility or the addition of a carboxylic acid plant to an existing ethanol plant.

The recent ruling by EPA upholding the requirement that all reformulated gasoline sold in California contain an oxygenate such as ethanol is expected to increase markets for agriculturally produced ethanol. Wheat and barley are viable alterative feedstocks for this processing. Beet sugar, though technically feasible, is not currently an economical choice. However, the beetprocessing plants, which include fermentation and evaporation units, could be incorporated into a new bacterial fermentation process to produce carboxylic acids which, in turn, can be reacted with ethanol to produce high-value "green" solvents, fuel additives, and other chemical products.

The growing of corn and the conversion of cornstarch to sugars remain the most economically viable scenario. Ethanol production operations are well defined; the economical production of the organic acids and esters still requires investigation.

The fermentation of sugars to low-molecular-weight organic acids is fairly well documented. However, fermentation of hydrolysate glucose (glucose solution for ethanol production) is less defined, particularly using ammonium as a process-buffering agent. The proposed research will support the development of the DFB concept, a process that integrates the production of ethanol (yeast fermentation) and carboxylic acids (bacterial fermentation) to produce high-value organic acid esters.

\section{Goals and Objectives}

The overall goal of the proposed project is to develop preliminary lactic acid yield data and to assess key technical issues related to lactic acid fermentation process development. This was accomplished through batch tests using different bacterial strains to evaluate lactic acid production rates and overall conversion efficiencies.

\section{Methods}

\section{Bacterial Strains}

Bacterial strains for the fermentation tests were selected to represent common industrial strains and strains that may become new industrial standards. These strains are outlined in Table 20. Lactobacillus delbruekii is a classical strain used in research and production of lactic acid. $L$. casei is a strain that has also been widely used in research. The two E. coli strains have been recently constructed and offer several advantages over conventional strains. First, the strains have been engineered to produce lactic acid from both hexoses, such as glucose, and from pentoses, such as xylose. Second, the mode of engineering is such that the production of other products from sugars, such as ethanol, acetate, etc., have been minimized. Third, the lactic acid enzymes produced by these strains produce a high yield of enantomerically pure L-lactic acid. 
Table 20. Bacterial Strains Selected for Lactic Acid Production Fermentations

\begin{tabular}{lccc}
\hline Bacterium & Strain & Source & Reference \\
\hline $\begin{array}{l}\text { Lactobacillus } \\
\text { delbruekii }\end{array}$ & B-445 & NRRL $^{1}$ & Stenroos et al. 1982 (19) \\
$\begin{array}{l}\text { Lactobacillus casei } \\
\text { Escherichia coli }\end{array}$ & B-441 & NRRL & Hujanen et al. 2001 (20) \\
Escherichia coli & FBR19 & Dien $^{2}$ & Dien et al. 2001 (21) \\
\hline
\end{tabular}

1. Northern Regional Research Laboratory, USDA, National Center for Agricultural Research, Peoria, llinois.

2. Bruce Dien, National Center for Agricultural Research, Peoria, Illinois.

Finally, one of the strains (FBR19) has been modified to better simultaneously ferment both pentoses and hexoses.

Once received, the bacterial strains were grown to a high density (overnight), supplemented with $10 \%$ glycerol, and stored at $-85^{\circ} \mathrm{C}$ until needed.

\section{Media}

The lactobacilli were cultured in MRS media (Difco, Table 21) at room temperature with minimal shaking (gyratory, ca. 50 rpm). E. coli FBR11 and FBR 19 were cultured aerobically in LB media (10 g tryptone, $5 \mathrm{~g}$ yeast extract, $5 \mathrm{~g}$ sodium chloride per liter) with erythromycin added at $400 \mu \mathrm{g} / \mathrm{L}$, and ampicillin at $100 \mu \mathrm{g} / \mathrm{L}$, respectively.

Table 21. Composition of MRS Media for Growth of Lactobacilli (Difco)

\begin{tabular}{lc}
\hline Component & $\mathrm{g} / \mathrm{L}$ \\
\hline Glucose & 20 \\
Proteose Peptone & 10 \\
Beef Extract & 10 \\
Sodium Acetate & 5 \\
Yeast Extract & 5 \\
$\mathrm{Na}_{2} \mathrm{HPO}_{4}$ & 2 \\
$\mathrm{Ammonium} \mathrm{Citrate}_{\mathrm{MgSO}} \cdot 7 \mathrm{H}_{2} \mathrm{O}$ & 2 \\
$\mathrm{MnSO}_{4} \cdot 4 \mathrm{H}_{2} \mathrm{O}$ & 0.1 \\
$\mathrm{Sorbitan} \mathrm{Monooleate}$ & 0.05 \\
\hline
\end{tabular}


Corn hydrolysate was obtained from the Archer Daniels Midland (ADM) ethanol plant located in Walhalla, North Dakota, on January 17, 2003. Preparation of this hydrolysate at the ADM plant involved grinding and slurrying of the corn, addition of $\alpha$-amylase and incubation at $93^{\circ} \mathrm{C}\left(200^{\circ} \mathrm{F}\right)$ until less viscous, then cooling to $60^{\circ} \mathrm{C}\left(140^{\circ} \mathrm{F}\right)$ and addition of glucoamylase. At the plant, this slurry is then added to vats for fermentation to ethanol. Approximately 37 liters of this hydrolysate was collected, cooled on ice, transported to the EERC, homogenized, and placed in $0.85 \mathrm{~L}$ aliquots, then frozen at $-18^{\circ} \mathrm{C}\left(0^{\circ} \mathrm{F}\right)$

Prior to using the hydrolysate, it was thawed, placed in a waterbath at $60^{\circ} \mathrm{C}$ for $30 \mathrm{~min}$, then centrifuged at $5850 \times \mathrm{g}$ for 20 minutes. The supernatant was filtered through a coarse glass frit to remove low-density solids, then used for fermentation. This amber liquid contained a small amount of corn oil and had a glucose concentration of about $300 \mathrm{~g} / \mathrm{L}$.

\section{Fermentations}

A B. Braun Biotech International Biostat B fermenter was used for all tests. This is a water-jacketed unit with a nominal 2-L volume. To initiate a fermentation test, a selected strain was thawed and used to inoculate a $10-\mathrm{mL}$ overnight culture of the appropriate media at $30^{\circ} \mathrm{C}$. The next day this culture was used to inoculate two 1-L Erlenmeyer seed flasks, each containing $250 \mathrm{~mL}$ of medium. These flasks were incubated at room temperature overnight with minimal shaking. The next morning, the $\mathrm{pH}$ meter was calibrated, the fermenter filled with the clarified corn hydrolysate, nutrients, and water to achieve the desired mixture for that test, the fermenter was heated to $35^{\circ} \mathrm{C}$, and the fermenter contents were sparged with nitrogen for about 20 minute. The overnight seed media was centrifuged at $5000 \times \mathrm{g}$, the pellet of microbes was suspended in $100 \mathrm{~mL}$ of distilled water and added to the fermenter. The fermenter was subjected to a rapid mix at ca. $850 \mathrm{rpm}$, then the stirring was set to $150 \mathrm{rpm}$ for the duration of the test. The $\mathrm{pH}$ of the fermenter was controlled to the desired set point with 4.3 $\mathrm{M}$ ammonium hydroxide. During the fermentation run, frequent samples were aseptically collected for glucose, acids, and cell count determinations. The fermentations were continued until the addition of base had ceased. Nutrient additions were Soytone ${ }^{\circledR}$ (Difco), a enzyme digest of soybean meal, and yeast extract (Difco), at $20 \mathrm{~g}$ and $10 \mathrm{~g}$, respectively, per batch.

\section{Analytical}

Total bacterial counts were performed by serially diluting fermentation broth in $0.1 \%$ sodium pyrophosphate (pH 7.0) and spread plating in duplicate onto Mann-Rogosa-Sharpe media (Table 2 plus 1.5\% agar) or Luria-Bertani media plus 1.5\% agar, for the lactobacilli and E. coli, respectively. The plates were incubated at $30^{\circ} \mathrm{C}$ and counted after $48 \mathrm{hr}$ of incubation. Dry weight was estimated by placing an aliquot of fermentation liquor into a tared dry microcentrifuge tube, pelleting the cells at 14,000 $\times \mathrm{g}$ for 2 minutes, followed by a wash with distilled water, pelleting the cells as before, and drying the tube and contents at $100^{\circ} \mathrm{C}$.

Carbohydrates were analyzed by a high-pressure liquid chromatography (HPLC) system consisting of a single Waters 510 pump connected to a Reodyne injector with a $20-\mu \mathrm{L}$ loop and then via very short tube to a $300 \times 7.8 \mathrm{~mm}$ Aminex HPX 87N carbohydrate analysis column 
(BioRad). The detector was also connected via a very short tube to a Waters RI detector. An HP 3390 was used for integration/plotting of the signal. The eluent solvent for the chromatography was deionized water, pumped at $1.2 \mathrm{~mL} / \mathrm{min}$. The system was calibrated for several mono- and disaccharides, including glucose, using five known concentrations from 0 to $10 \mathrm{mg} / \mathrm{mL}$.

Fermentation acids were analyzed via an HPLC system consisting of a single Waters 501 pump connected to a Beckman injector with a $20-\mu \mathrm{L}$ loop and then to a $300 \times 7.8$ Sierra Separations organic acid analysis column. The detector is a Kratos UV unit set to $210 \mathrm{~nm}$. An HP 3390 was used for integration/plotting of the signal. The eluent solvent was $0.003 \mathrm{~N}$ sulfuric acid at a flow rate of $0.6 \mathrm{~mL} / \mathrm{min}$. The system was calibrated for several organic acids, including lactic, formic, acetic, propionic, and butyric acids, using five known concentrations of each acid.

\section{Results and Discussion}

The fermentation tests were performed under the conditions outlined in Table 22. The temperature and mixing were the same in all tests. The pHs used were selected as optimal based on the literature. Test 3, using $L$. casei was a repeat of Test 2 because of the lower initial glucose in that test. Test 4, using $L$. casei without added nutrients, was performed to determine if the nutrients were in fact necessary to achieve rapid rates and high yields. Test 5 , also with $L$. casei, was performed to compare the rates and yield of pure glucose with the corn hydrolysate.

Table 22. Fermentation Test Conditions

\begin{tabular}{lcccc}
\hline Test No. & Bacterium & Feedstock & Nutrients & $\mathrm{pH}$ \\
\hline 1 & L. delbruekii & Corn hydrolysate & Yes & 6.3 \\
2 & L. casei & Corn hydrolysate & Yes & 6.3 \\
3 & L. casei & Corn hydrolysate & Yes & 6.3 \\
4 & L. casei & Corn hydrolysate & No & 6.3 \\
5 & L. casei & Glucose & Yes & 6.3 \\
6 & E. coli FBR 11 & Corn hydrolysate & Yes & 6.7 \\
7 & E. coli FBR 19 & Corn hydrolysate & Yes & 6.7 \\
\hline
\end{tabular}

The fermentation with $L$. delbruekii proceeded quite rapidly, as Figure 37, the consumption of base, shows. There was a short lag period of a few hours, followed by rapid fermentation, leading to a plateau, with the end of the fermentation occurring after about $24 \mathrm{hr}$. Figure 38 shows the consumption of carbohydrates during this fermentation, with the same pattern observed as for base consumption. The corn hydrolysate contained small amounts of maltose and an oligomer that were sometimes consumed along with the glucose. Figure 39 


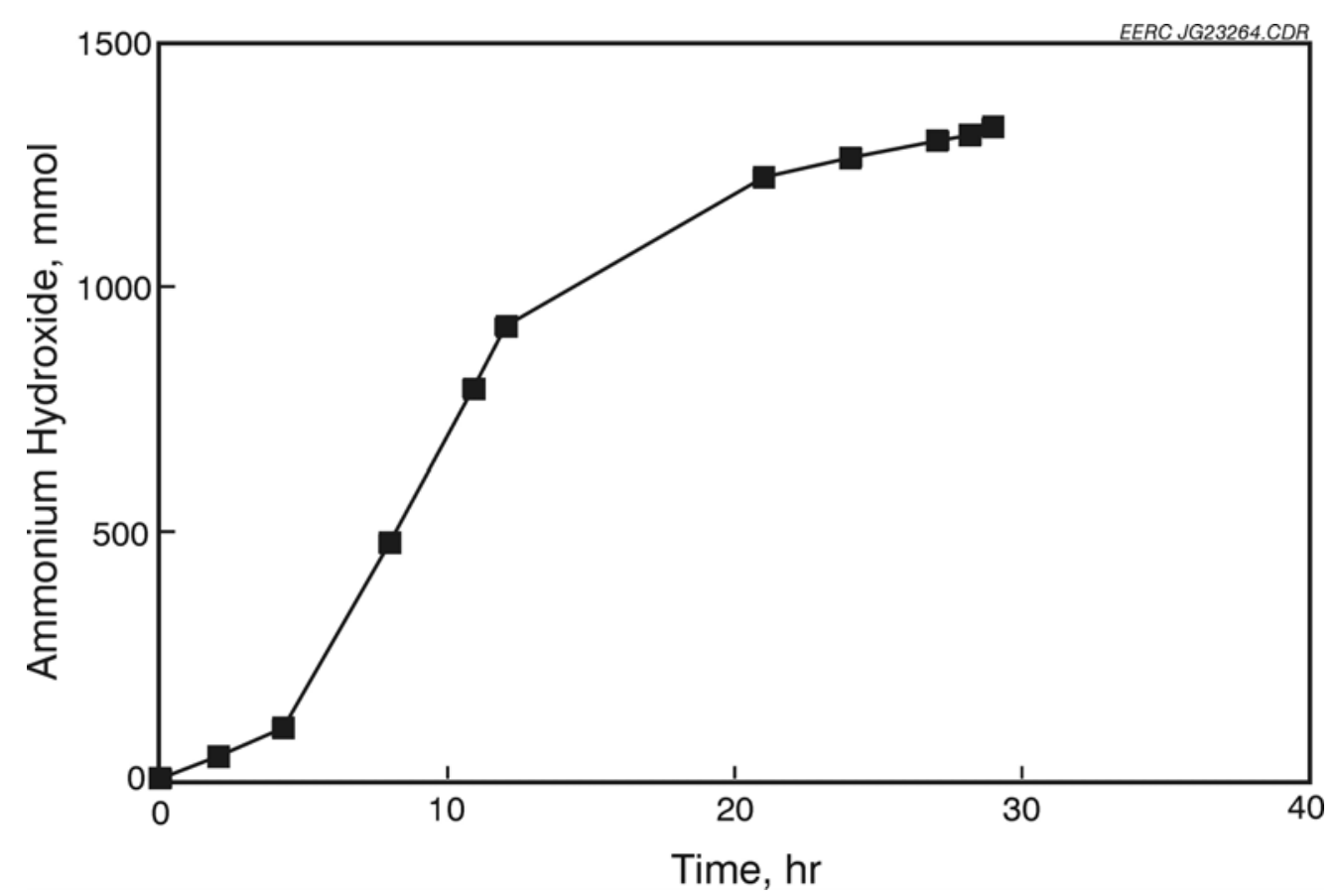

Figure 37. Cumulative consumption of 4.3 $\mathrm{M}$ ammonium hydroxide during the fermentation of corn hydrolysate by L. delbruekii (nutrients added, initial glucose $99 \mathrm{~g} / \mathrm{L}$ ).

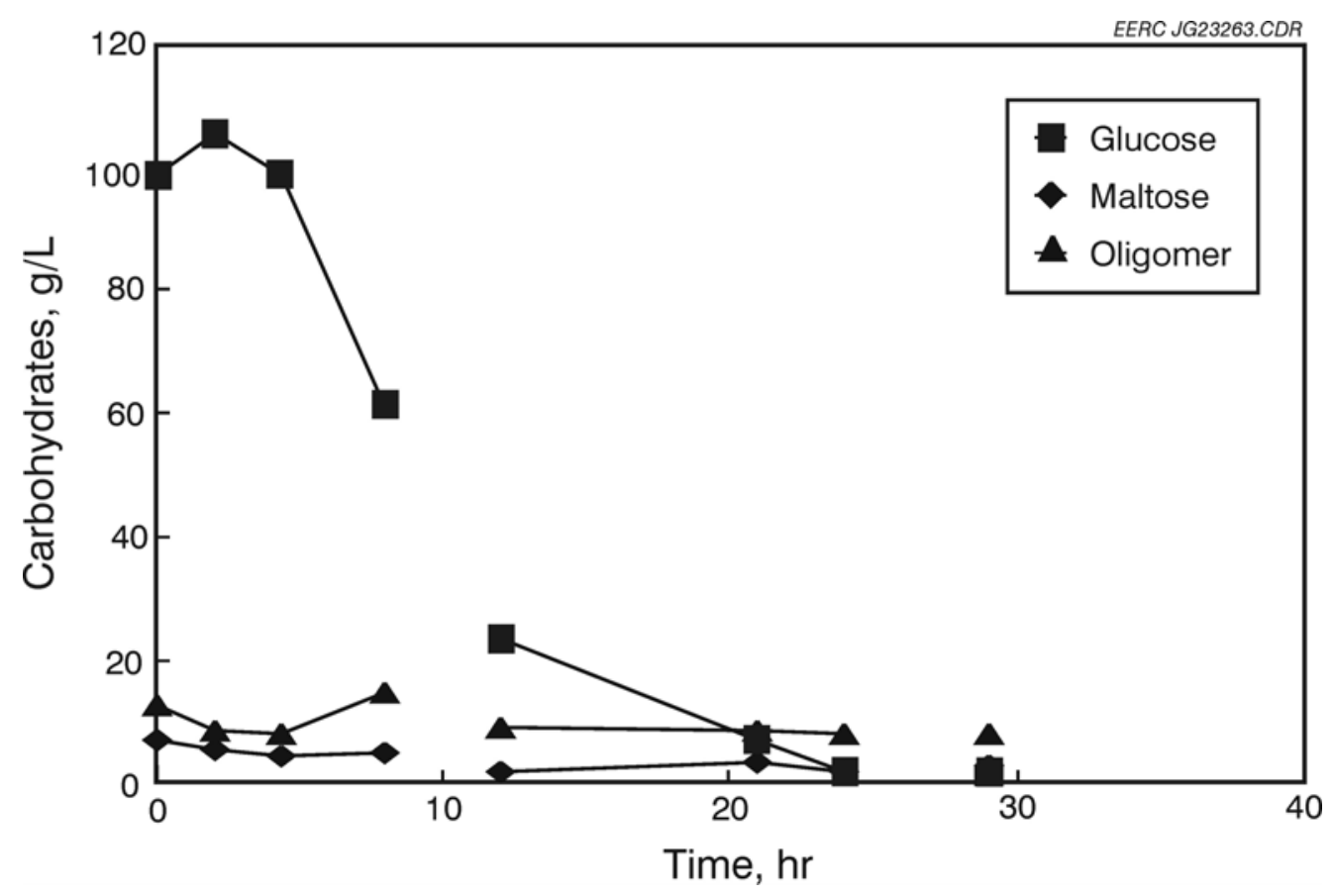

Figure 38. Consumption of carbohydrates in the fermentation of corn hydrolysate by L. delbruekii (nutrients added, initial glucose $99 \mathrm{~g} / \mathrm{L}$ ). 


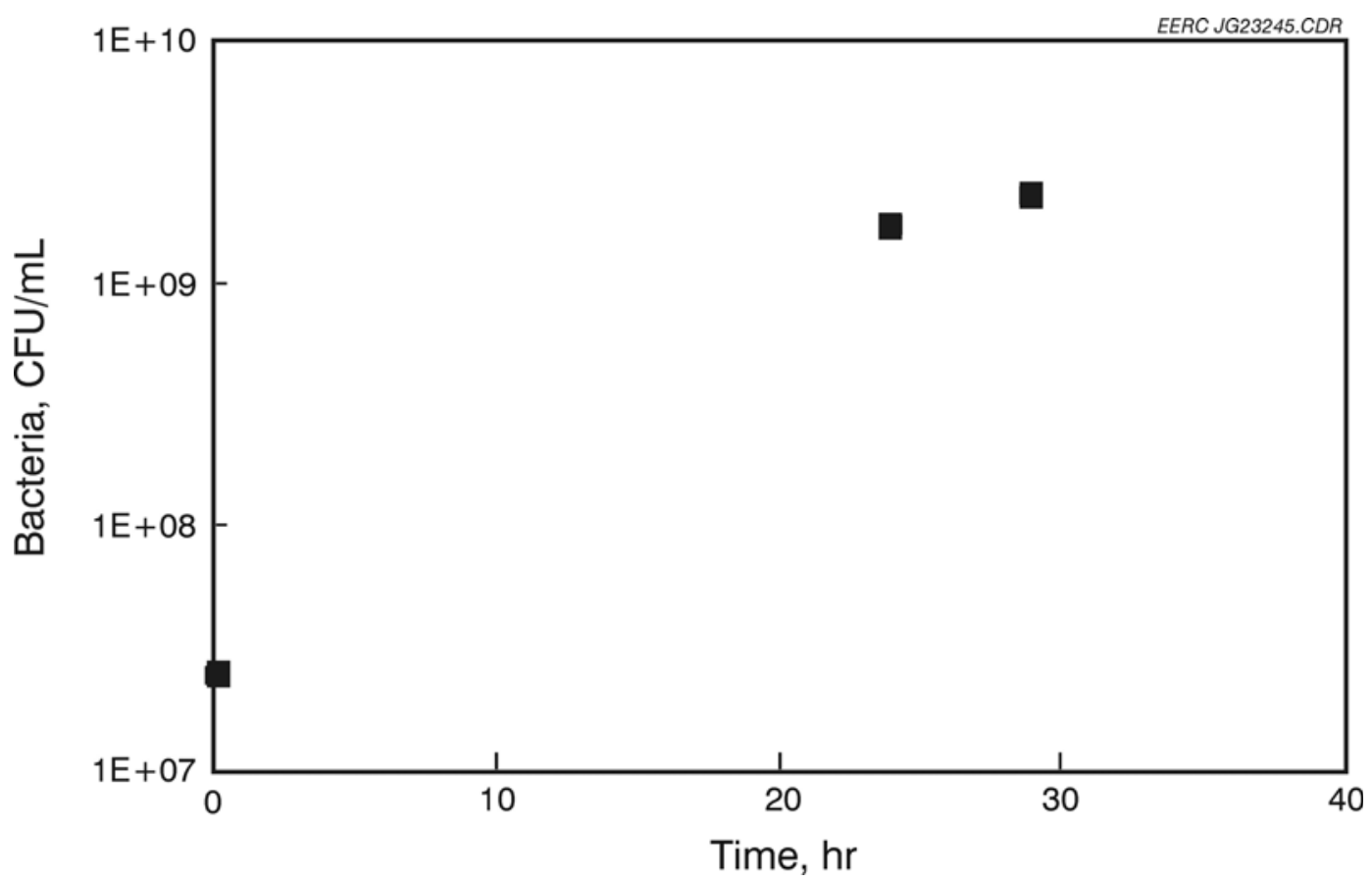

Figure 39. Total bacteria counts of the fermentation broth during the fermentation of corn hydrolysate by $L$. delbruekii (nutrients added, initial glucose $99 \mathrm{~g} / \mathrm{L}$ ).

shows the total count of bacteria in this fermentation. Only a few data points were collected, showing an increase of two logs (from $2.4 \times 10^{7}$ to $2.3 \times 10^{9} / \mathrm{mL}$ ) over the fermentation. Lactic acid was the principal acid formed, with very small amounts of acetic and propionic acids (Figure 40). Efficiency of fermentation, calculated as the percent weight of lactate formed of the initial glucose, is shown in Figure 41. The total efficiency of this fermentation was 62.6\%.

The base usage during the fermentation of corn hydrolysate by L. casei is shown in Figure 42. No significant lag period is noted, and a plateau period that shows a continuing slow usage of base is noted. This fermentation is largely complete in about $12 \mathrm{hr}$. The consumption of carbohydrates is shown in Figure 43, with the bulk of the glucose consumed by about $10 \mathrm{hr}$. Total bacteria counts, shown in Figure 44, show that the initial bacteria count is higher than in the previous fermentation, accounting for the shorter lag period. The count increased about 1.5 logs (from $5.0 \times 10^{8}$ to $3.0 \times 10^{10} / \mathrm{mL}$ ). The production of fermentation acids is shown in Figure 45. This figure shows that very small amounts of acetic and propionic acids were produced. Fermentation efficiency, shown in Figure 46, was $82.8 \%$ at $12 \mathrm{hr}$, but increased to $98.8 \%$ at $26 \mathrm{hr}$.

The next fermentation, also with $L$. casei, was performed because the previous results showed a very rapid rate and high efficiency, but the initial glucose concentration was somewhat low. Figure 47 shows the base consumption during the fermentation, with a lag of about $2 \mathrm{hr}$ and consumption essentially complete by $12 \mathrm{hr}$. The consumption of glucose, shown in Figure 48, 


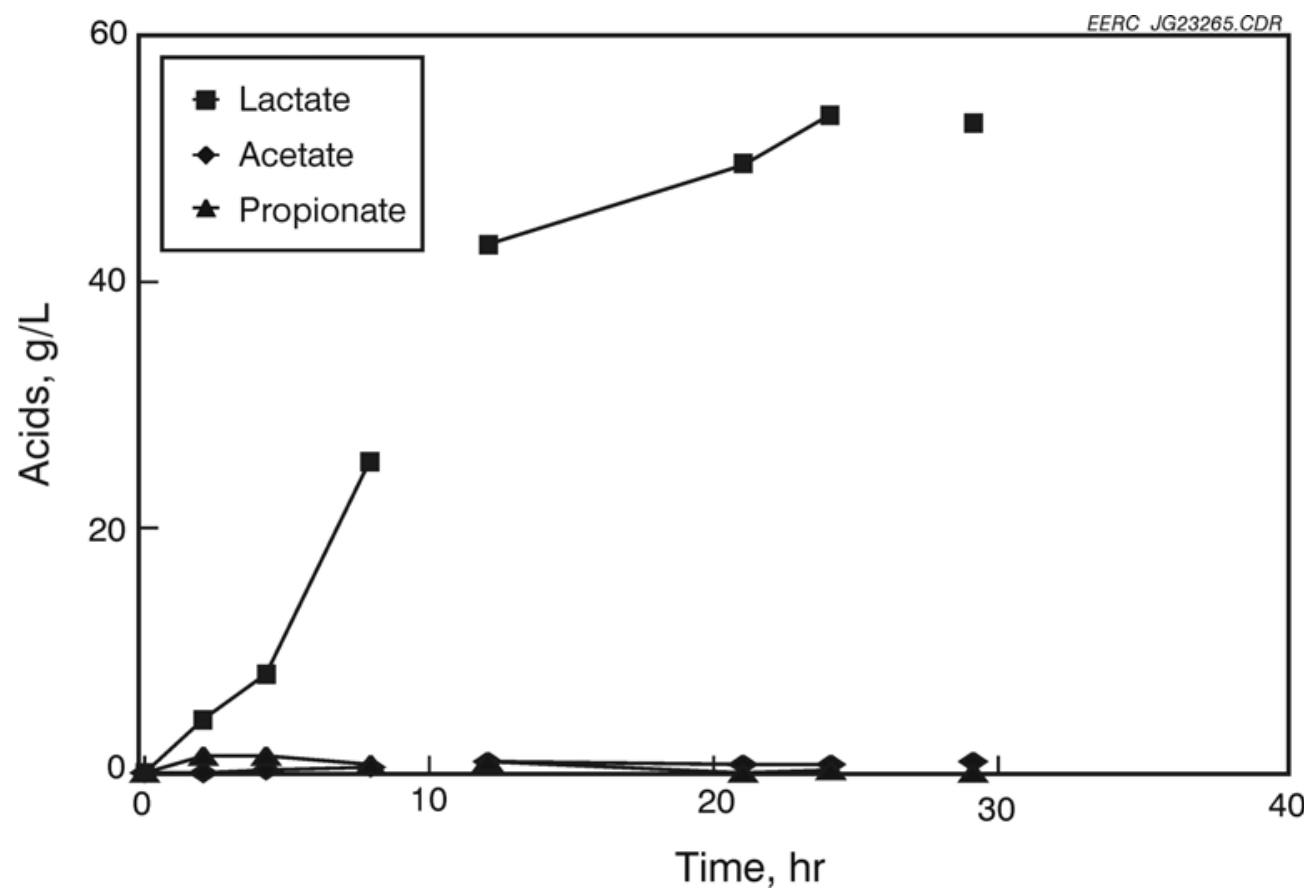

Figure 40. Production of fermentation acids $L$. delbruekii during the fermentation of corn hydrolysate (nutrients added, initial glucose $99 \mathrm{~g} / \mathrm{L}$ ).

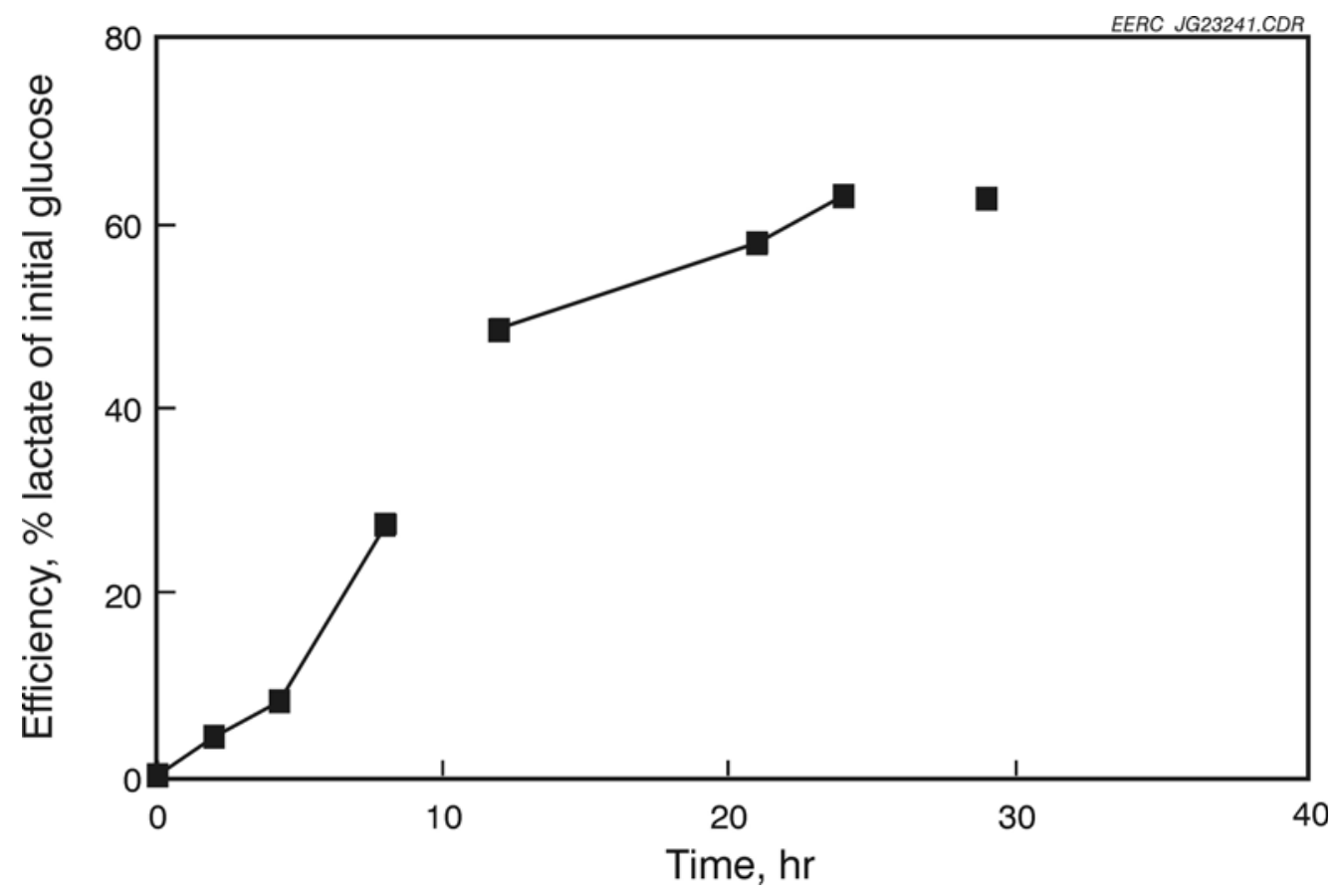

Figure 41. Efficiency of fermentation, expressed as the weight of lactic acid produced compared to the initial glucose concentration, during the fermentation of corn hydrolysate by L. delbruekii (nutrients added, initial glucose $99 \mathrm{~g} / \mathrm{L}$ ). 


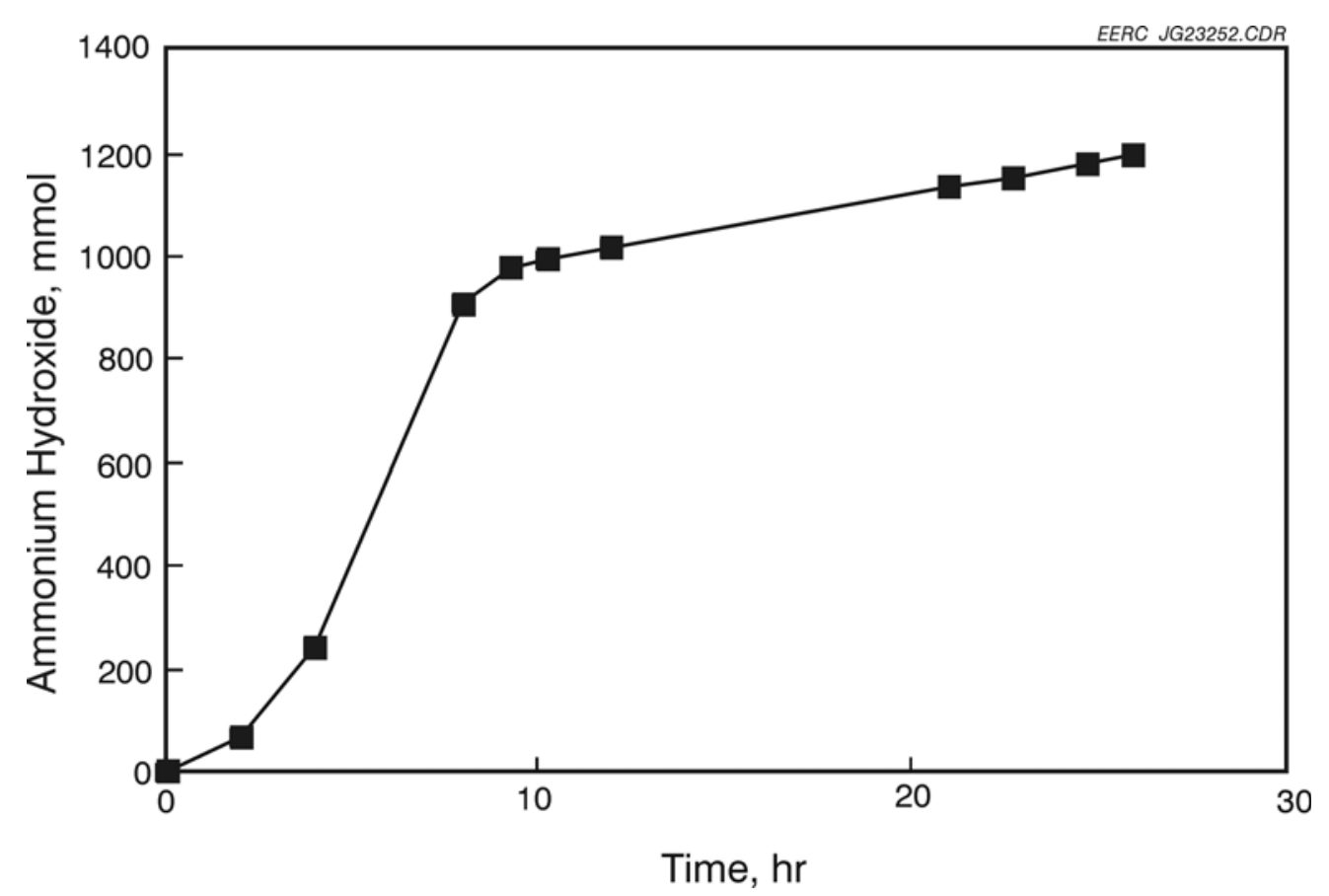

Figure 42. Cumulative consumption of 4.3 $\mathrm{M}$ ammonium hydroxide during the fermentation of corn hydrolysate by $L$. casei (corn hydrolysate, with nutrients, initial glucose $75 \mathrm{~g} / \mathrm{L}$ ).

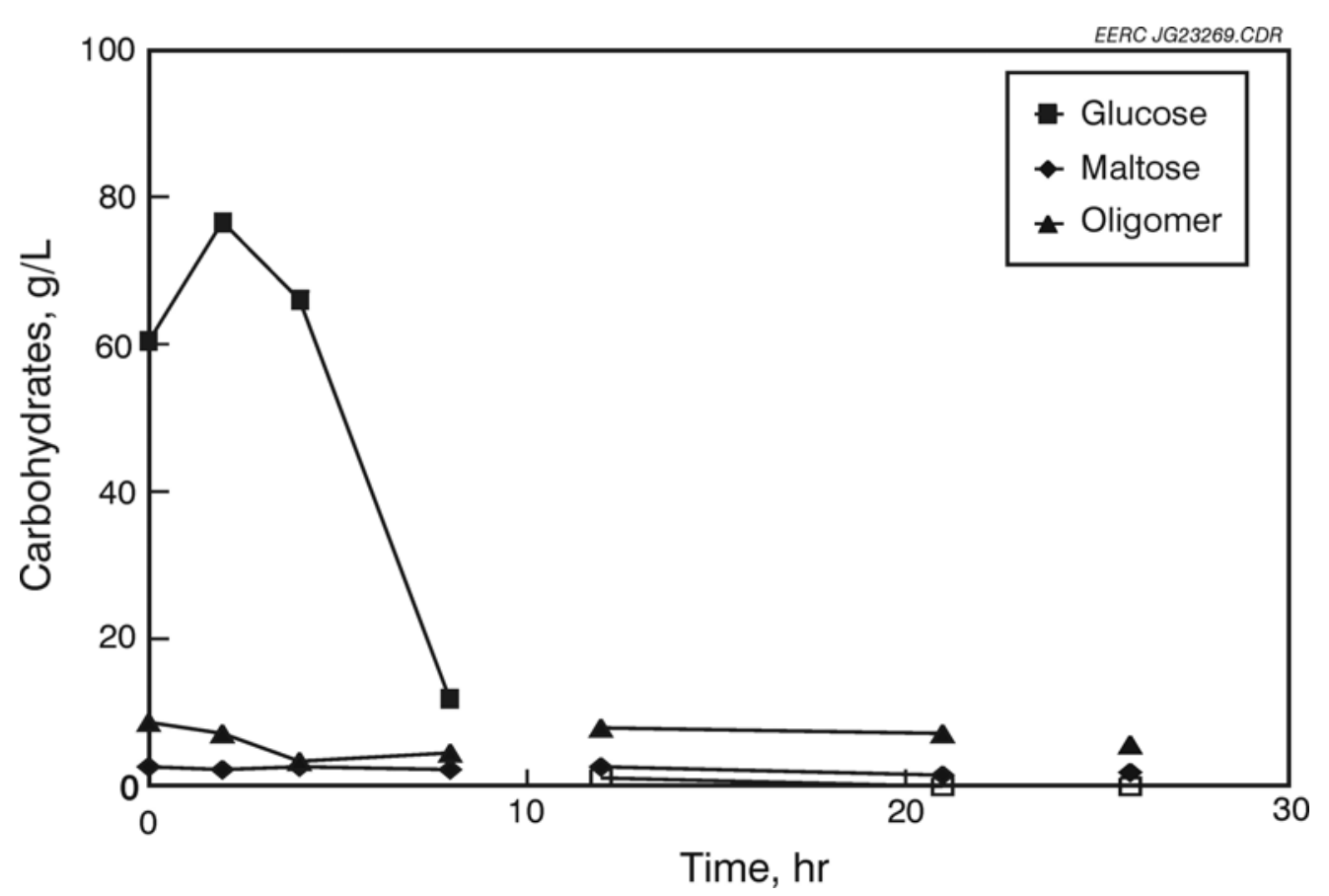

Figure 43. Consumption of carbohydrates in the fermentation of corn hydrolysate by L. casei (corn hydrolysate, with nutrients, initial glucose 75g/L). 


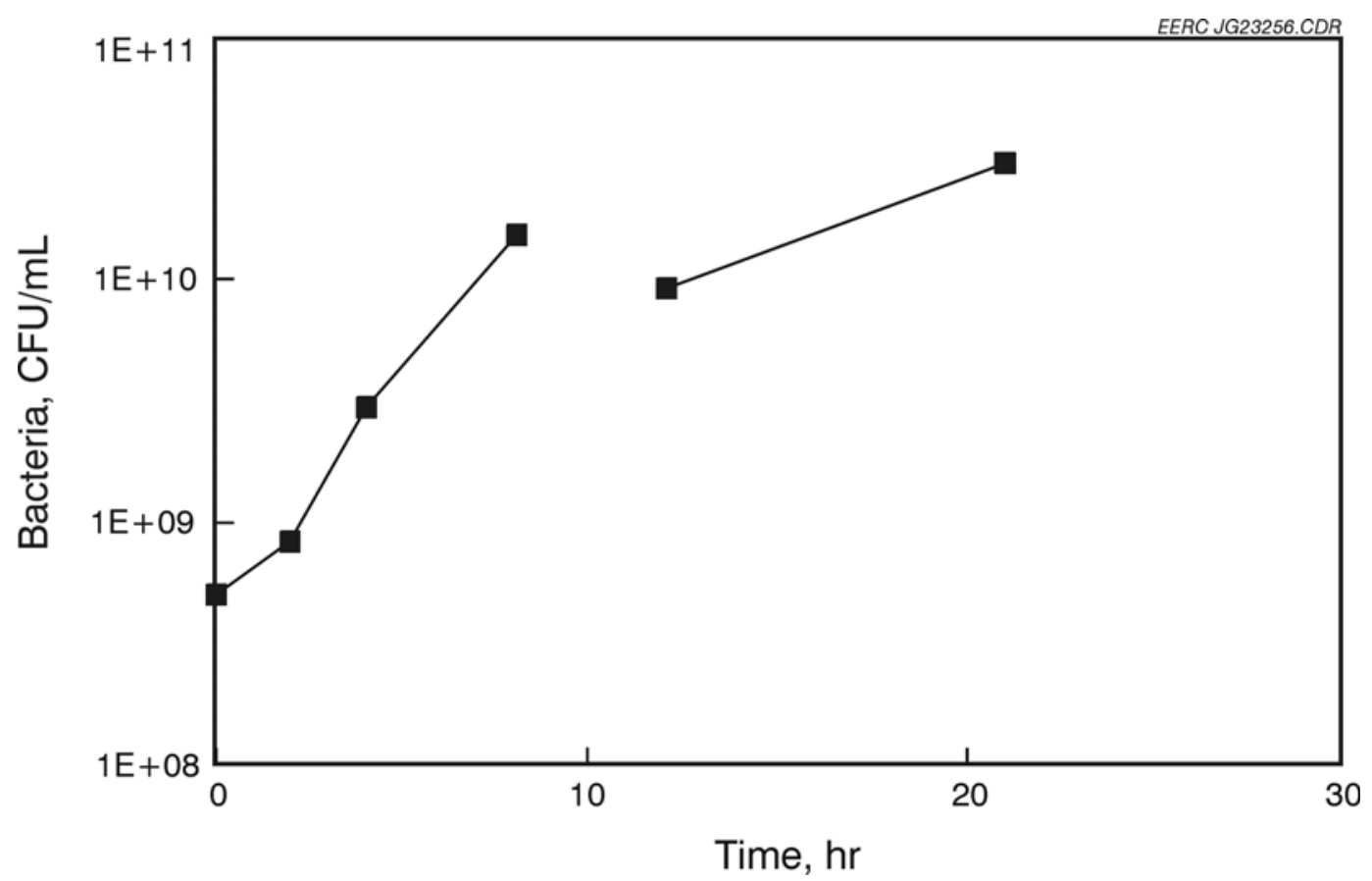

Figure 44. Total bacteria counts of the fermentation broth during the fermentation of corn hydrolysate by L. casei (corn hydrolysate, with nutrients, initial glucose $75 \mathrm{~g} / \mathrm{L}$ ).

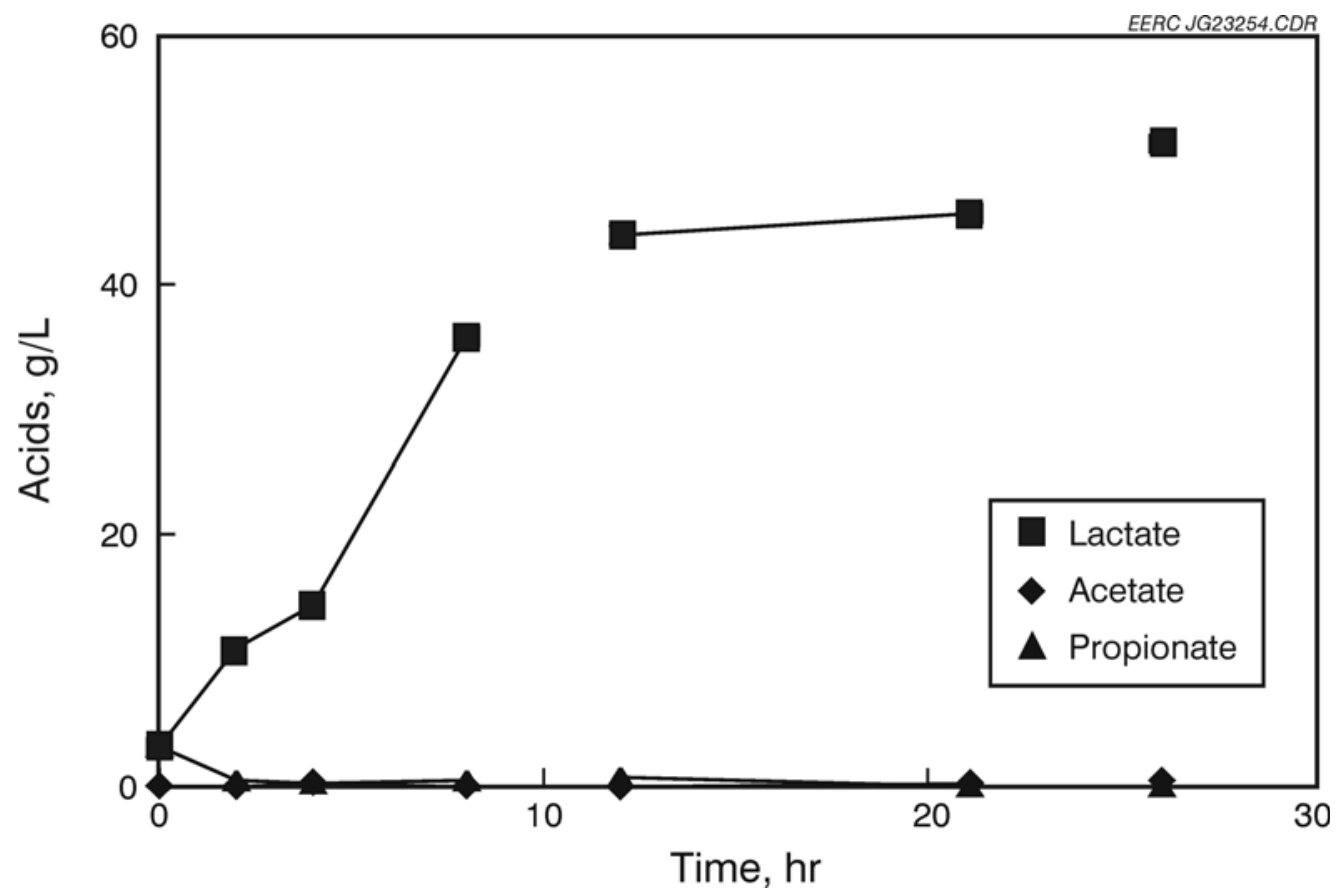

Figure 45. Production of fermentation acids by L. casei during the fermentation of corn hydrolysate (nutrients added, initial glucose $75 \mathrm{~g} / \mathrm{L}$ ). 


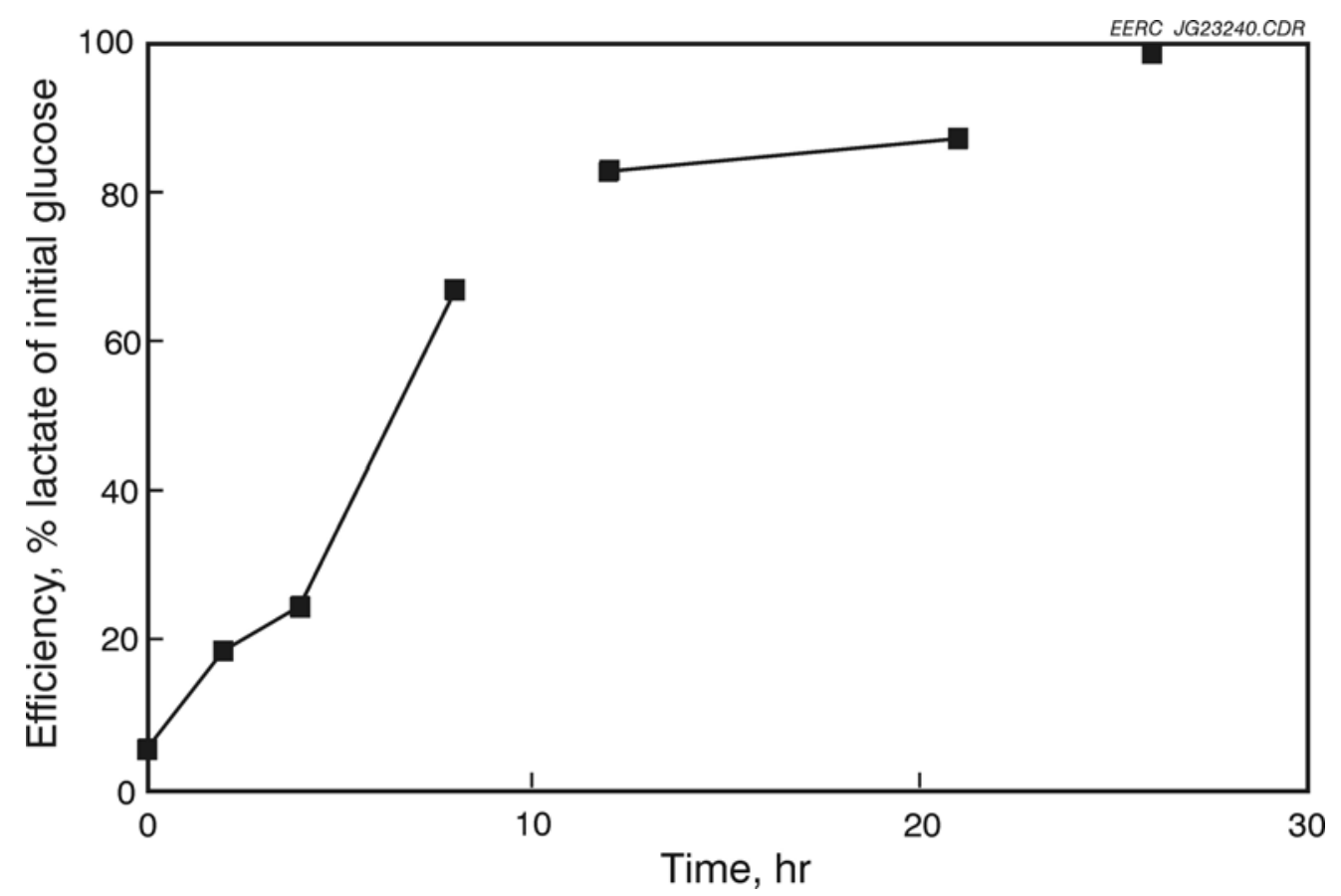

Figure 46. Efficiency of fermentation, expressed as the weight of lactic acid produced compared to the initial glucose concentration, during the fermentation of corn hydrolysate by $L$. casei (nutrients added, initial glucose $75 \mathrm{~g} / \mathrm{L}$ ).

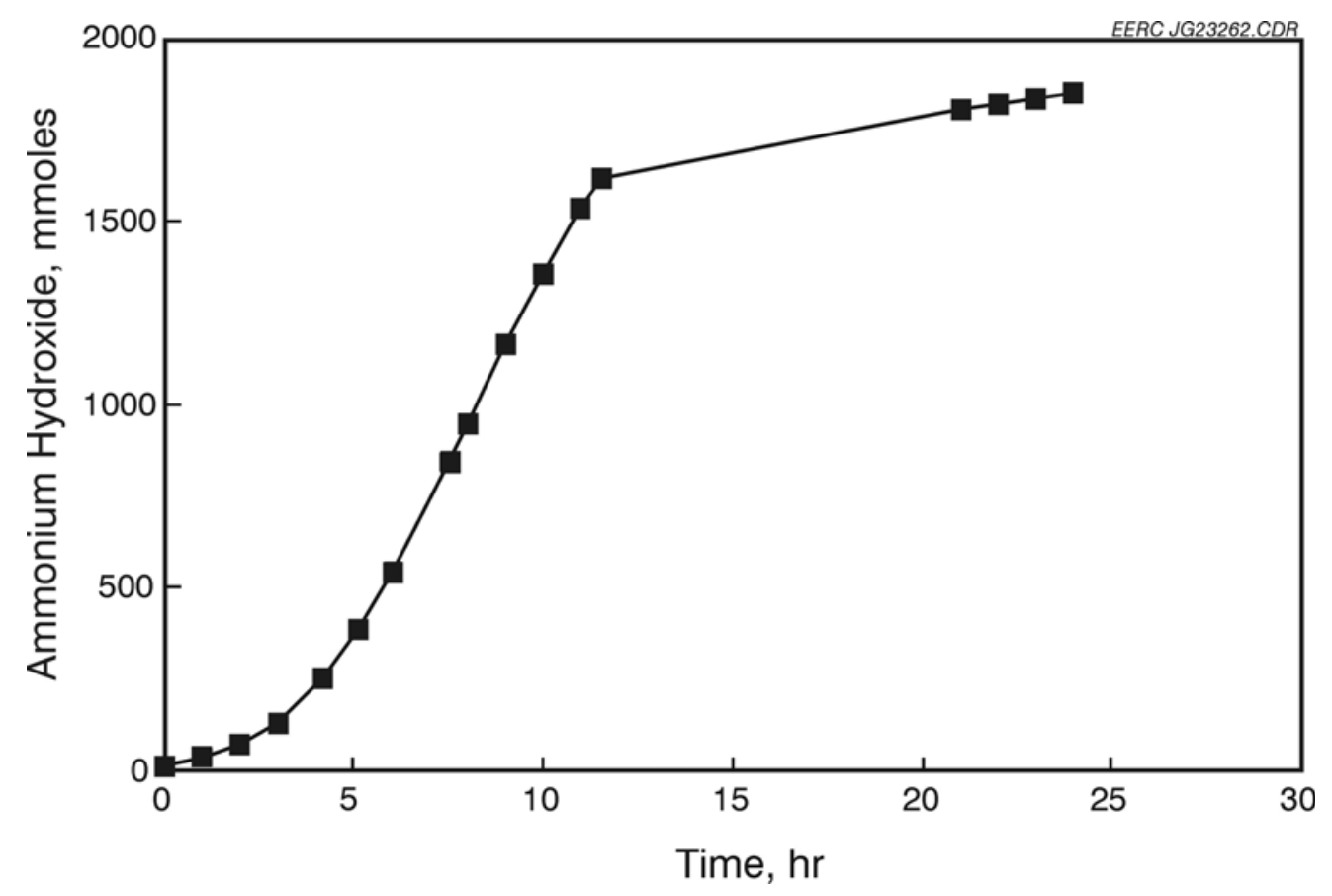

Figure 47. Cumulative consumption of $4.3 \mathrm{M}$ ammonium hydroxide during the fermentation of corn hydrolysate by $L$. casei (nutrients added, initial glucose $119 \mathrm{~g} / \mathrm{L}$ ). 


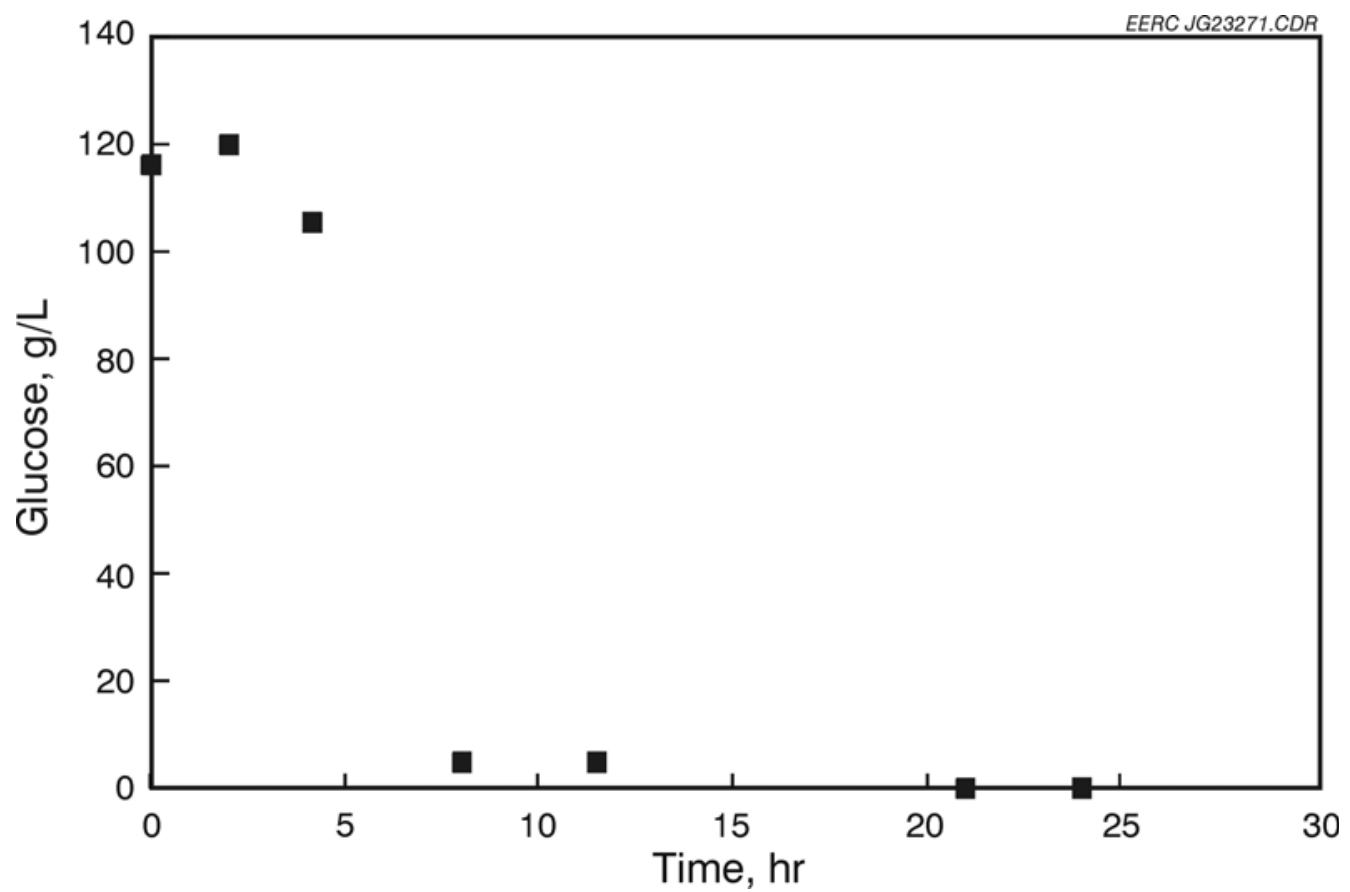

Figure 48. Consumption of carbohydrates in the fermentation of corn hydrolysate by $L$. casei (nutrients added, initial glucose $119 \mathrm{~g} / \mathrm{L}$ ).

was essentially complete by about $8 \mathrm{hr}$. Bacteria counts (Figure 49) started at $7.9 \times 10^{8}$ and increased to $3.2 \times 10^{10}$ after $24 \mathrm{hr}$. The production of acids was essentially complete by $12 \mathrm{hr}$ (Figure 50). The efficiency of this fermentation was much lower than that observed in the first $L$. casei fermentation, peaking at $69.1 \%$ (Figure 51).

The next $L$. casei fermentation was conducted without the addition of the Soytone ${ }^{\circledR}$ and yeast extract nutrients. As this bacterium had shown the best fermentation rates thus far, it was hoped that there might be sufficient nutrients in the corn hydrolysate to perform the fermentation, thus reducing costs. Figure 52 shows the consumption of base in this fermentation. The base consumption is linear and without a lag period. The consumption of glucose shows the same linear pattern and is not completely consumed until after $53 \mathrm{hr}$ (Figure 53). Total bacteria counts (Figure 54) began at $5.9 \times 10^{8}$ and increased to the maximum of $1.1 \times 10^{10} / \mathrm{mL}$ at about $20 \mathrm{hr}$. After $20 \mathrm{hr}$ of fermentation, cell death began, indicating that nutrients were lacking. The production of fermentation acids also shows linear kinetics (Figure 55). Efficiency for this fermentation was $52.8 \%$ after $53 \mathrm{hr}$ (Figure 56).

The last $L$. casei fermentation was conducted using laboratory glucose and nutrients to develop a comparison with the corn hydrolysate. Figure 57 shows the consumption of base during this fermentation. The base consumption shows a short lag period of about $2 \mathrm{hr}$ followed by rapid fermentation that does not quite plateau after about $30 \mathrm{hr}$. Figure 58 shows the consumption of glucose in this fermentation. After $30 \mathrm{hr}$ of fermentation, the glucose was 


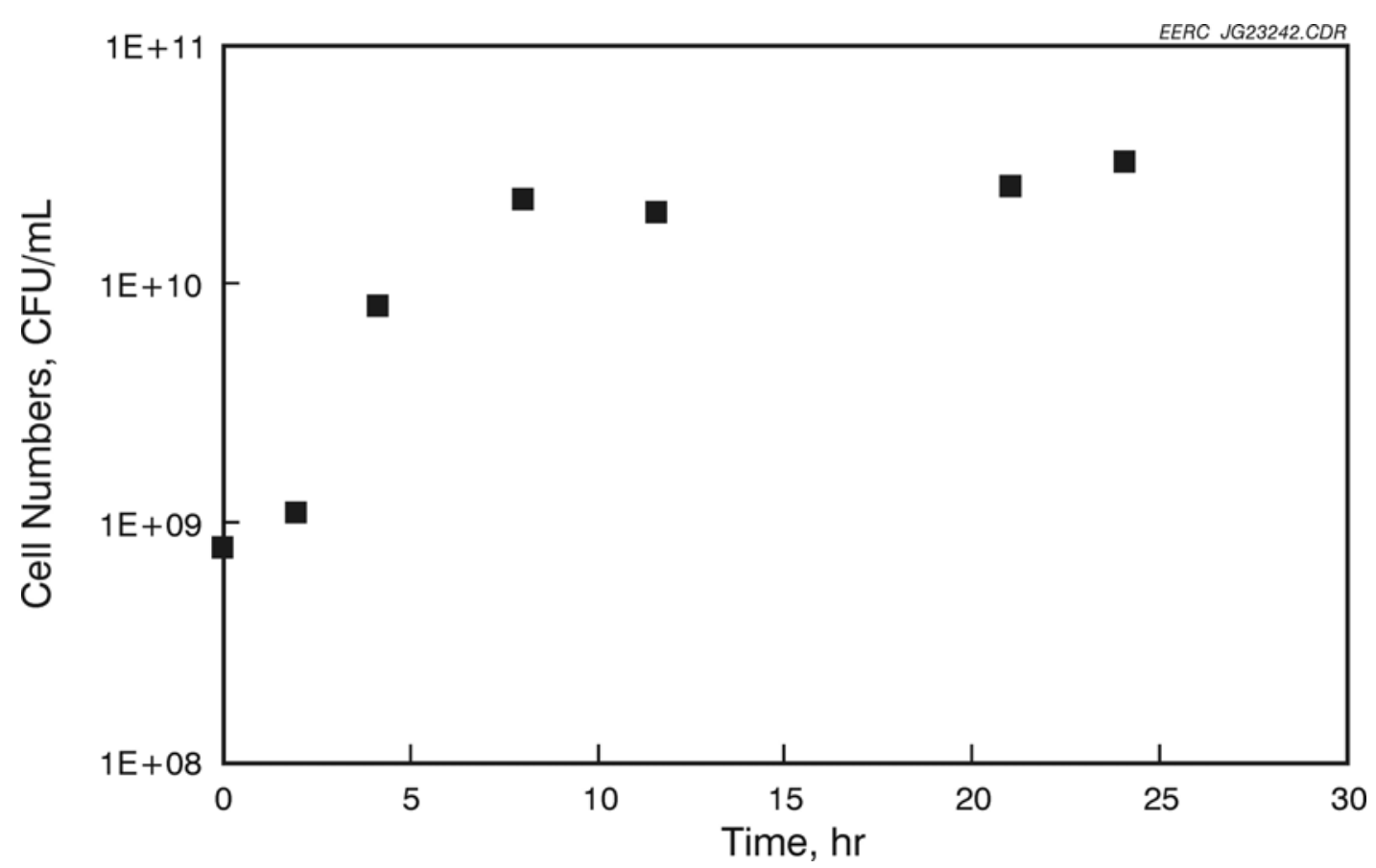

Figure 49. Total bacteria counts of the fermentation broth during the fermentation of corn hydrolysate by $L$. casei (nutrients added, initial glucose $119 \mathrm{~g} / \mathrm{L}$ ).

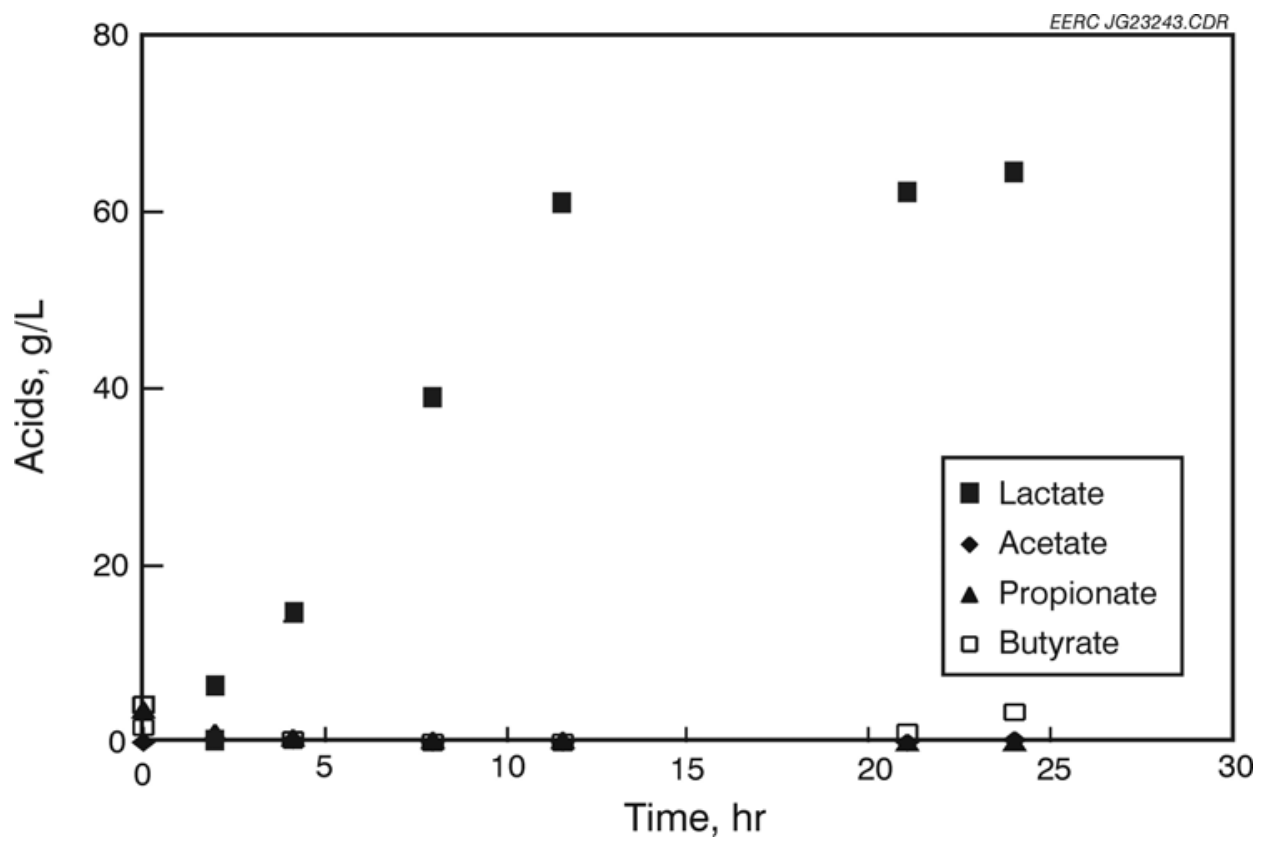

Figure 50. Production of fermentation acids by L. casei during the fermentation of corn hydrolysate (nutrients added, initial glucose $119 \mathrm{~g} / \mathrm{L}$ ). 


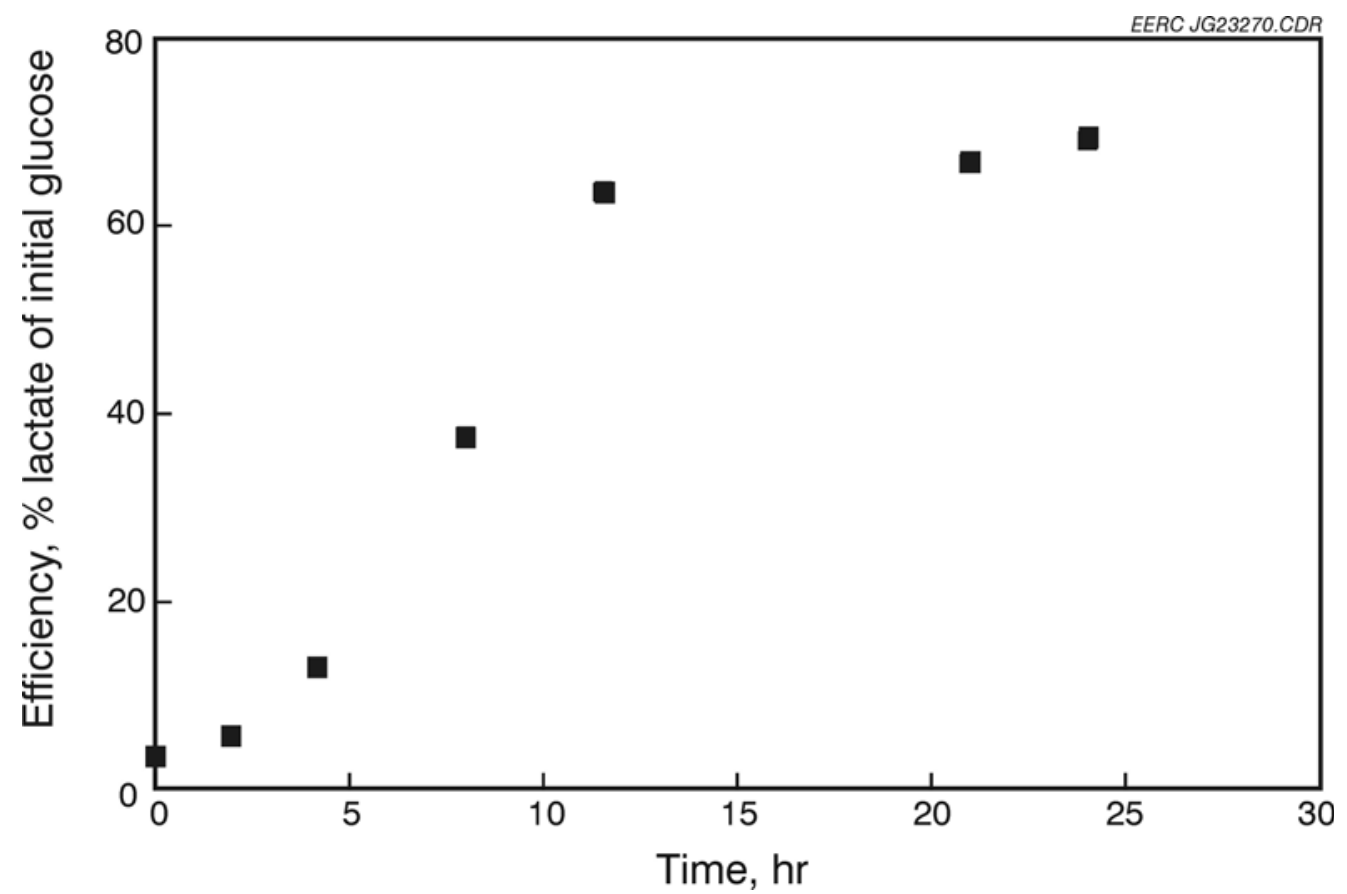

Figure 51. Efficiency of fermentation, expressed as the weight of lactic acid produced compared to the initial glucose concentration, during the fermentation of corn hydrolysate by $L$. casei (nutrients added, initial glucose $119 \mathrm{~g} / \mathrm{L}$ ).

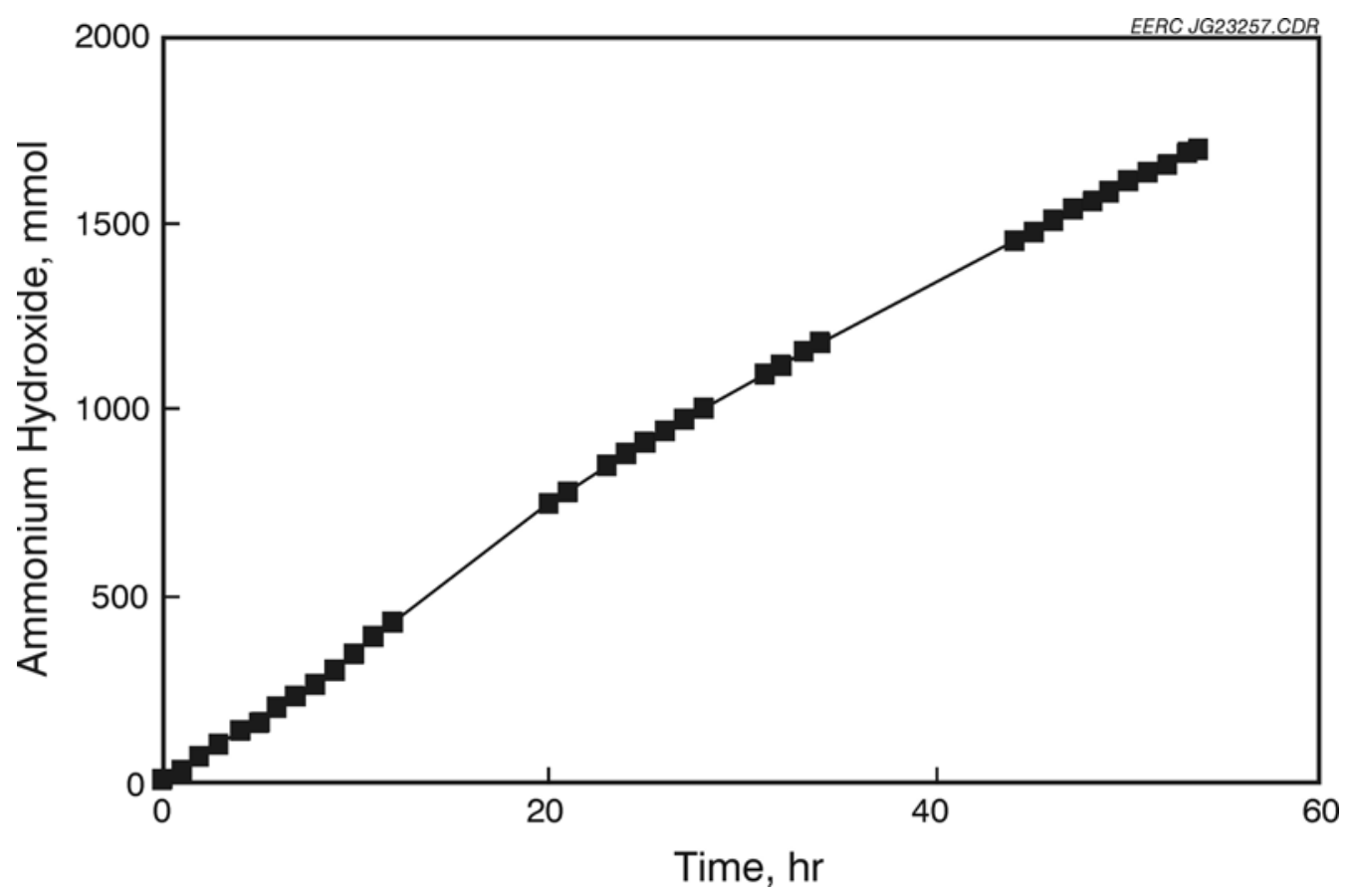

Figure 52. Cumulative consumption of $4.3 \mathrm{M}$ ammonium hydroxide during the fermentation of corn hydrolysate by L. casei (no nutrients, initial glucose $130 \mathrm{~g} / \mathrm{L}$ ). 


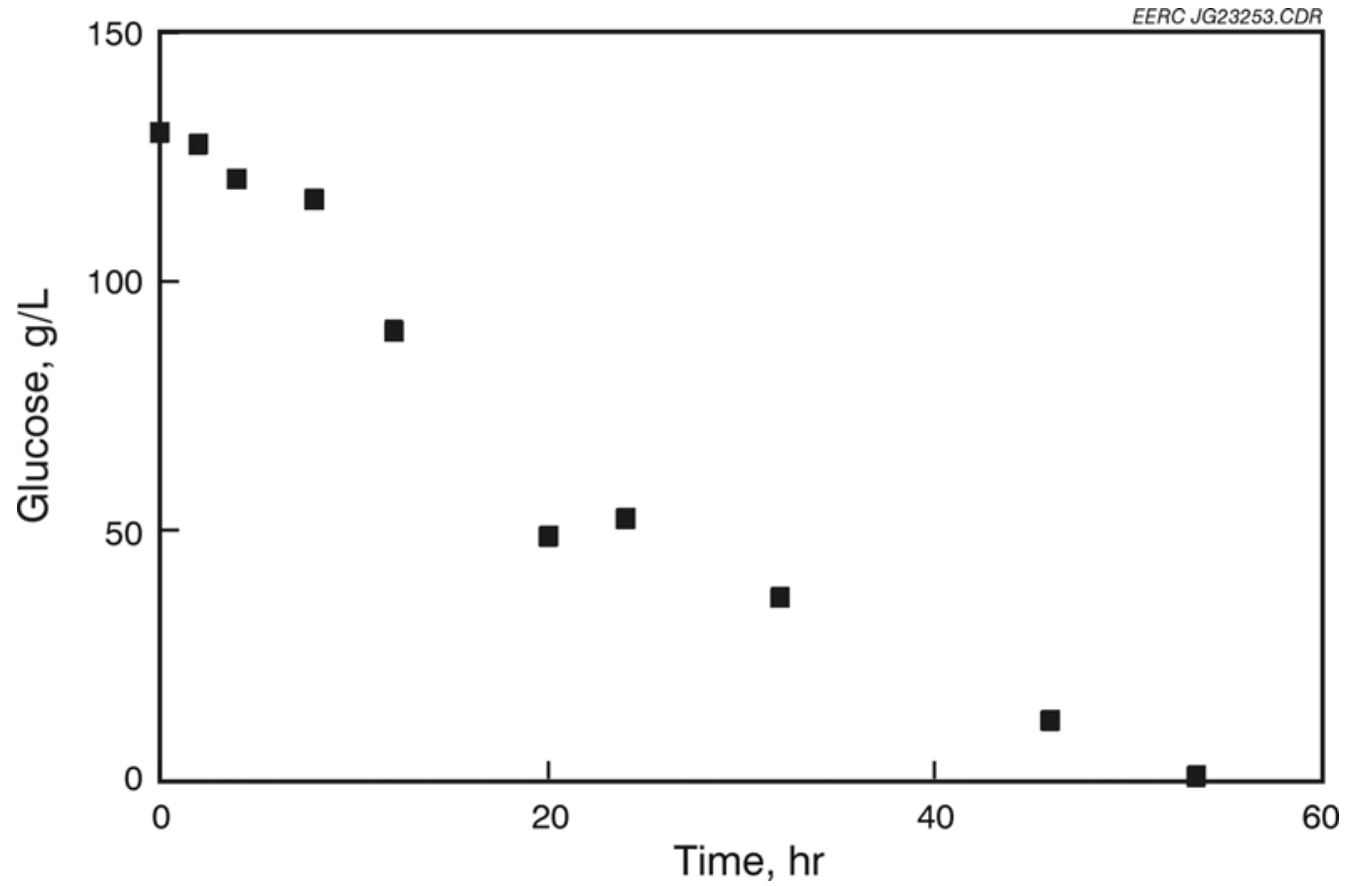

Figure 53. Consumption of carbohydrates in the fermentation of corn hydrolysate by L. casei (no nutrients, initial glucose $130 \mathrm{~g} / \mathrm{L}$ ).

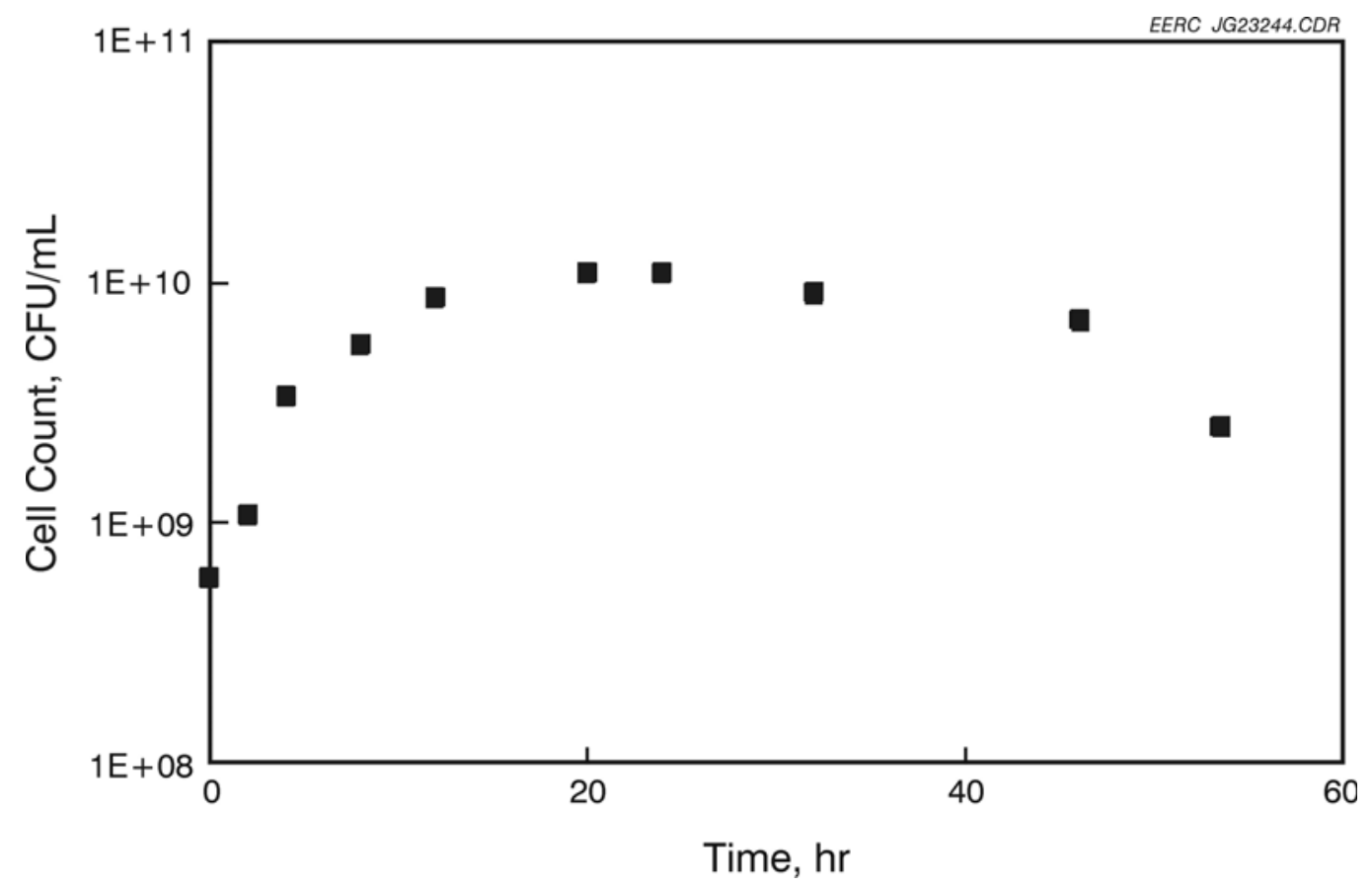

Figure 54. Total bacteria counts of the fermentation broth during the fermentation of corn hydrolysate by $L$. casei (no nutrients, initial glucose $130 \mathrm{~g} / \mathrm{L}$ ). 


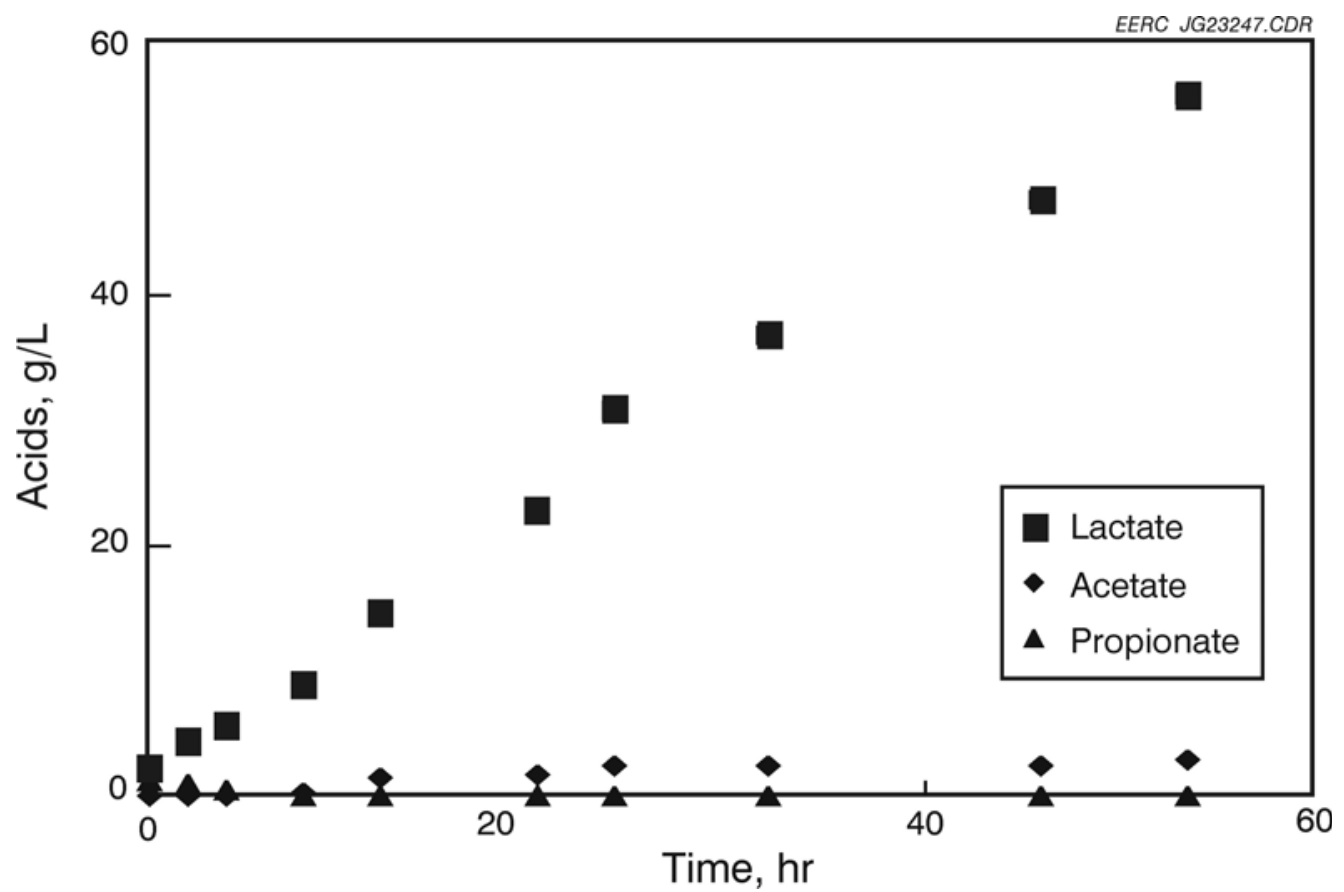

Figure 55. Production of fermentation acids by L. casei during the fermentation of corn hydrolysate (no nutrients, initial glucose $130 \mathrm{~g} / \mathrm{L}$ ).

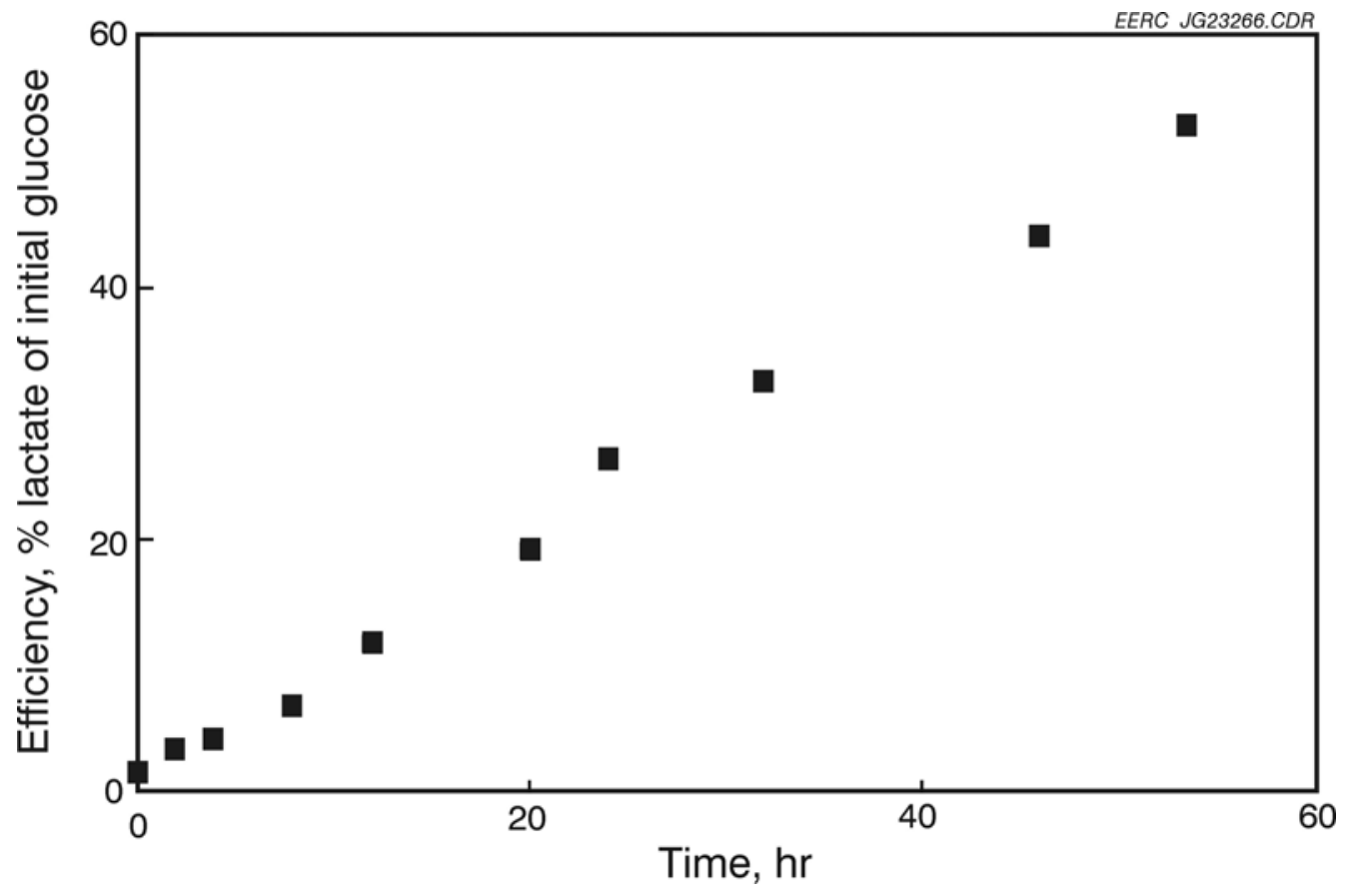

Figure 56. Efficiency of fermentation, expressed as the weight of lactic acid produced compared to the initial glucose concentration, during the fermentation of corn hydrolysate by L. casei (no nutrients, initial glucose $130 \mathrm{~g} / \mathrm{L}$ ). 


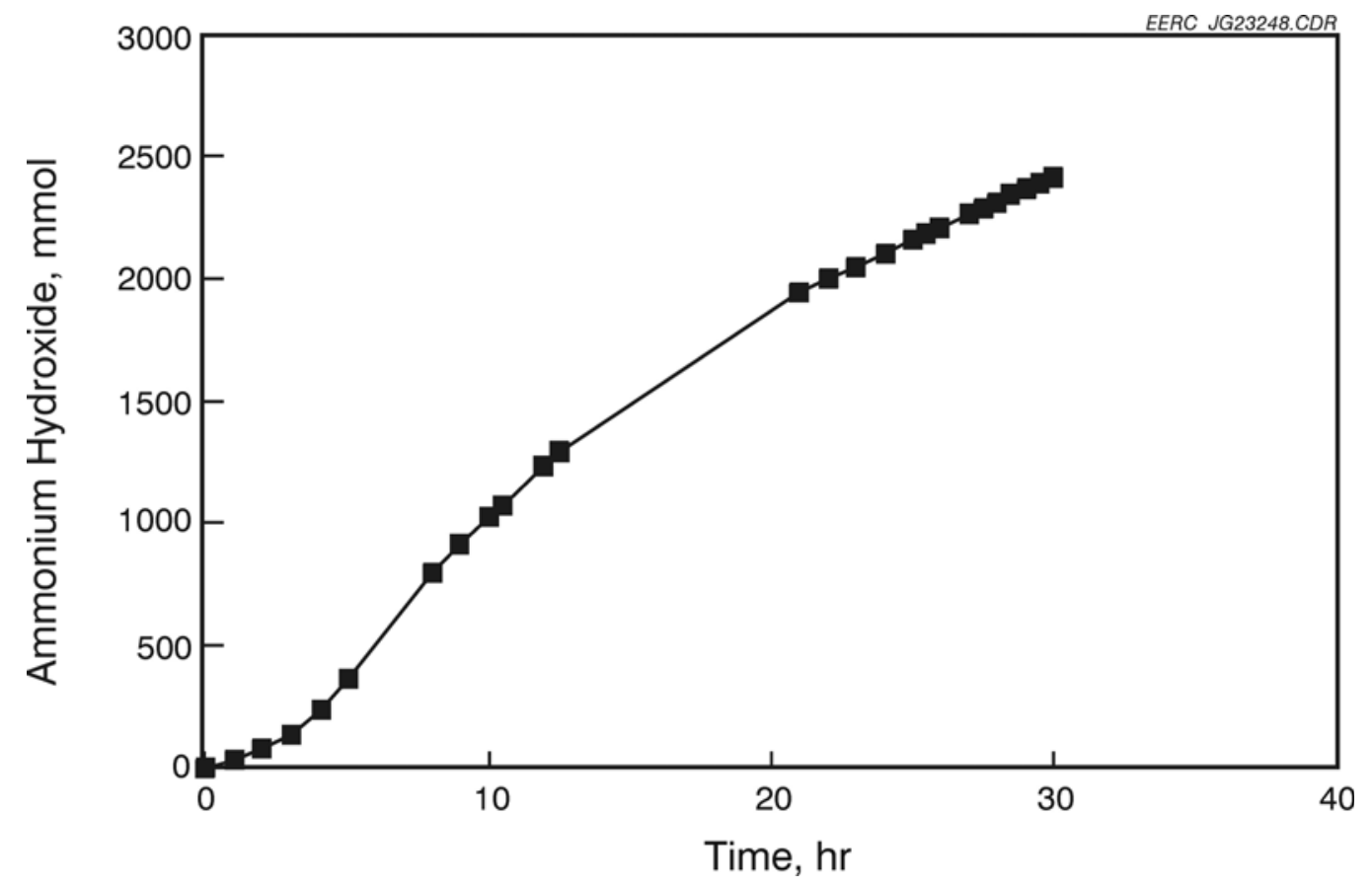

Figure 57. Cumulative consumption of 4.3 $\mathrm{M}$ ammonium hydroxide during the fermentation of glucose by L. casei (nutrients added, initial glucose $177 \mathrm{~g} / \mathrm{L}$ ).

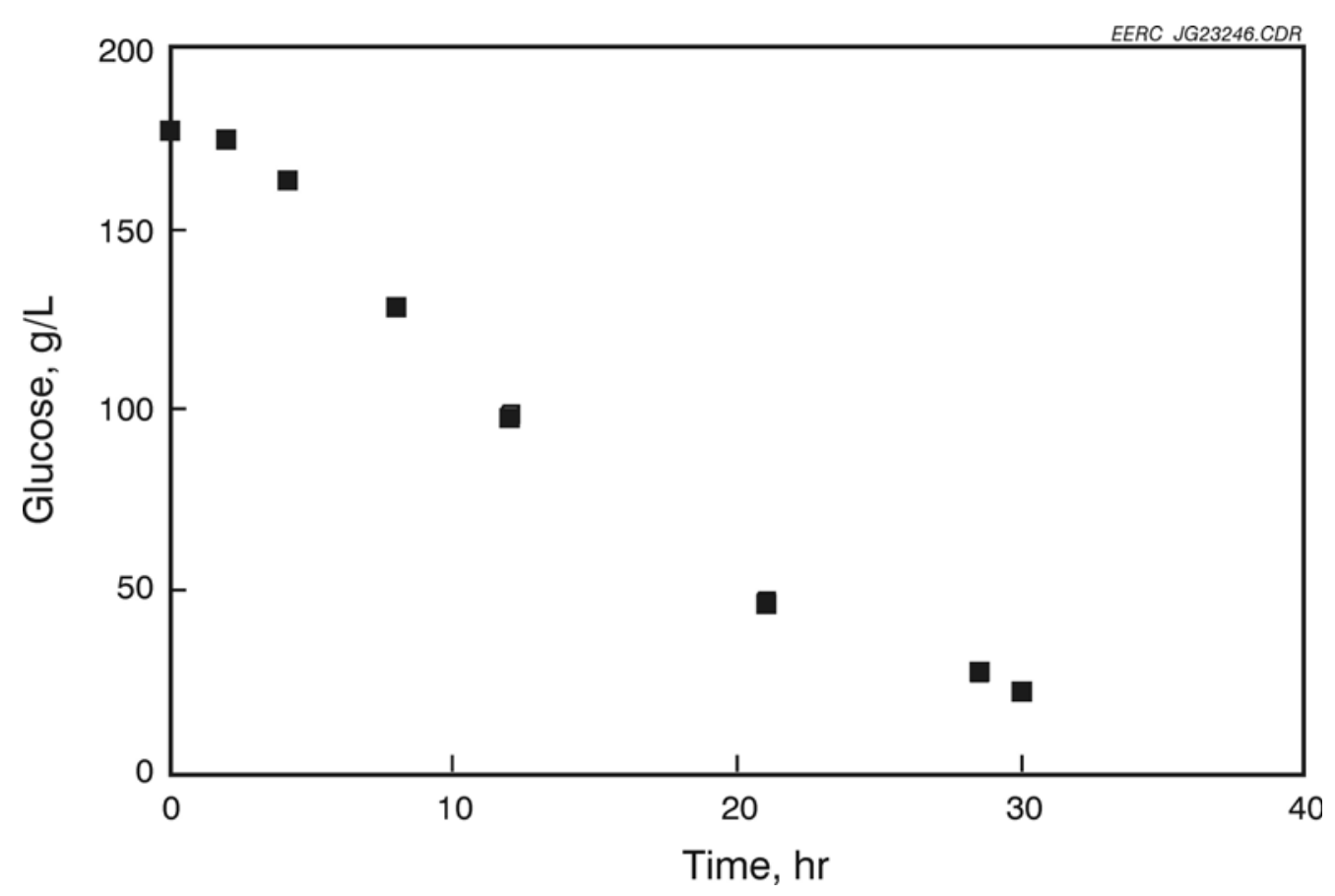

Figure 58. Consumption of carbohydrates in the fermentation of glucose by L. casei (nutrients added, initial glucose $177 \mathrm{~g} / \mathrm{L}$ ). 
$21.6 \mathrm{~g} / \mathrm{L}$. Total bacteria counts for this fermentation are shown in Figure 59. The growth was rapid, beginning at $4.1 \times 10^{8}$ and peaking at about $2.6 \times 10^{10} / \mathrm{mL}$. Lactic acid production, shown in Figure 60, peaks at $145.3 \mathrm{~g}(62.8 \mathrm{~g} / \mathrm{L})$ at $30 \mathrm{hr}$. Fermentation efficiency peaked at $46.9 \%$ (Figure 61).

Base consumption during the fermentation of $E$. coli strain FBR11 using corn hydrolysate and nutrients is shown in Figure 62. These data show a lag period of 3-4 hr and a plateau around $22 \mathrm{hr}$. Carbohydrate consumption, shown in Figure 63, indicates complete consumption of glucose by $24 \mathrm{hr}$. Maltose was also consumed. Total bacteria counts began at $1.1 \times 10^{8}$ and increased to $6.5 \times 10^{9} / \mathrm{mL}$ during the fermentation (Figure 64). Lactic acid production peaked at $51.7 \mathrm{~g} / \mathrm{L}$ (108.7 g), as shown in Figure 65. The fermentation efficiency peaked at 55.5\% (Figure $66)$.

Consumption of base by E. coli FBR 19 during the fermentation corn hydrolysate with nutrients is shown in Figure 67. These data show a lag period of about $1 \mathrm{hr}$ and that the fermentation was complete at about $21 \mathrm{hr}$. Glucose consumption, shown in Figure 68, shows that a small amount of glucose (2.6 g/L) remained unfermented after $26 \mathrm{hr}$. Total bacteria counts began at $9.4 \times 10^{7}$ and peaked at $7.2 \times 10^{9} / \mathrm{mL}$ (Figure 69). The production of fermentation acids, shown in Figure 70, indicates that significant amounts of other acids were also formed. However, these acids decreased somewhat by the end of the fermentation. Efficiency of this fermentation, shown in Figure 71, peaks at 34.8\%.

Table 23 shows the initial glucose concentrations, amount of glucose consumed, the final lactic acid concentration, and the total weight of lactic acid produced. The concentration of glucose at the start of each fermentation varied depending on the concentration of glucose in the batch of corn hydrolysate. In most cases, all or nearly all of the glucose was consumed during the fermentation. Table 24 shows the lag periods, maximum rate of lactic acid production, and the time required to consume all of the glucose. In some cases, this time was estimated. Also, note that in some cases, lactic acid production and base consumption continued after the glucose was consumed. The continued production of lactic acid after the glucose was consumed may be due to the cells using up internal stores of glucose.

The fastest rate of lactic acid production, and the overall most rapid fermentation, was noted with $L$. casei, although the E. coli FBR11 consumed the glucose as quickly. However the E. coli FBR 11 only had an efficiency of 55.5\%, while $L$. casei had efficiencies of 53\%-69\%. For comparison, the rate observed by L. casei by Hujanen et al. (20) was $4.4 \mathrm{~g} / \mathrm{L}$-hr on glucose with malt sprout extract and yeast extract as nutrients, with an efficiency of $84 \%$. Many other studies have found efficiencies ranging from $70 \%$ to $99 \%$ (23). Somewhat lower efficiencies were found in these fermentations. The lower observed efficiencies may be due to potential differences in the inoculum size. A lower inoculum size would require significantly more growth, resulting in a smaller yield. 


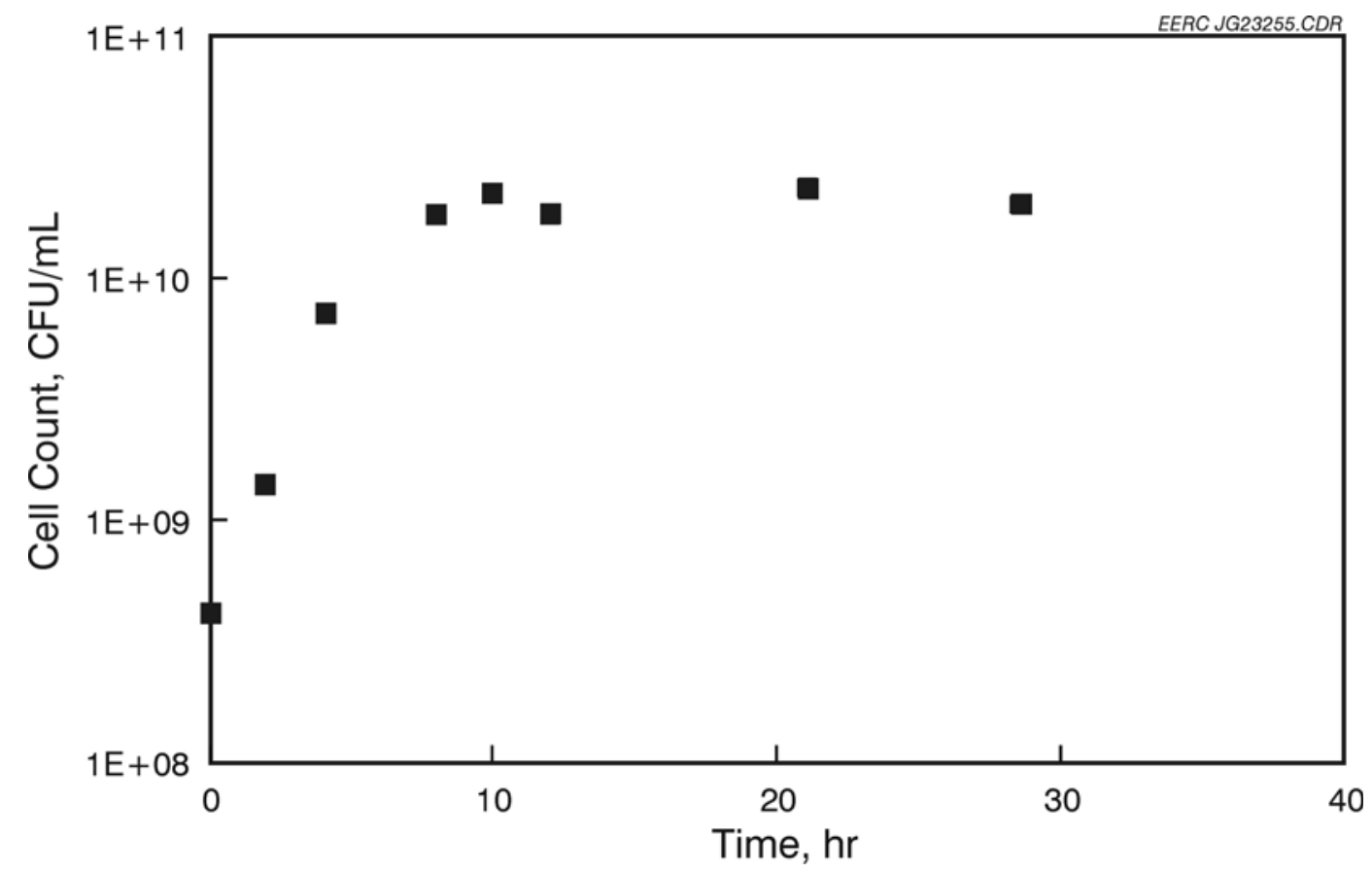

Figure 59. Total bacteria counts of the fermentation broth during the fermentation of glucose by L. casei (nutrients added, initial glucose $177 \mathrm{~g} / \mathrm{L}$ ).

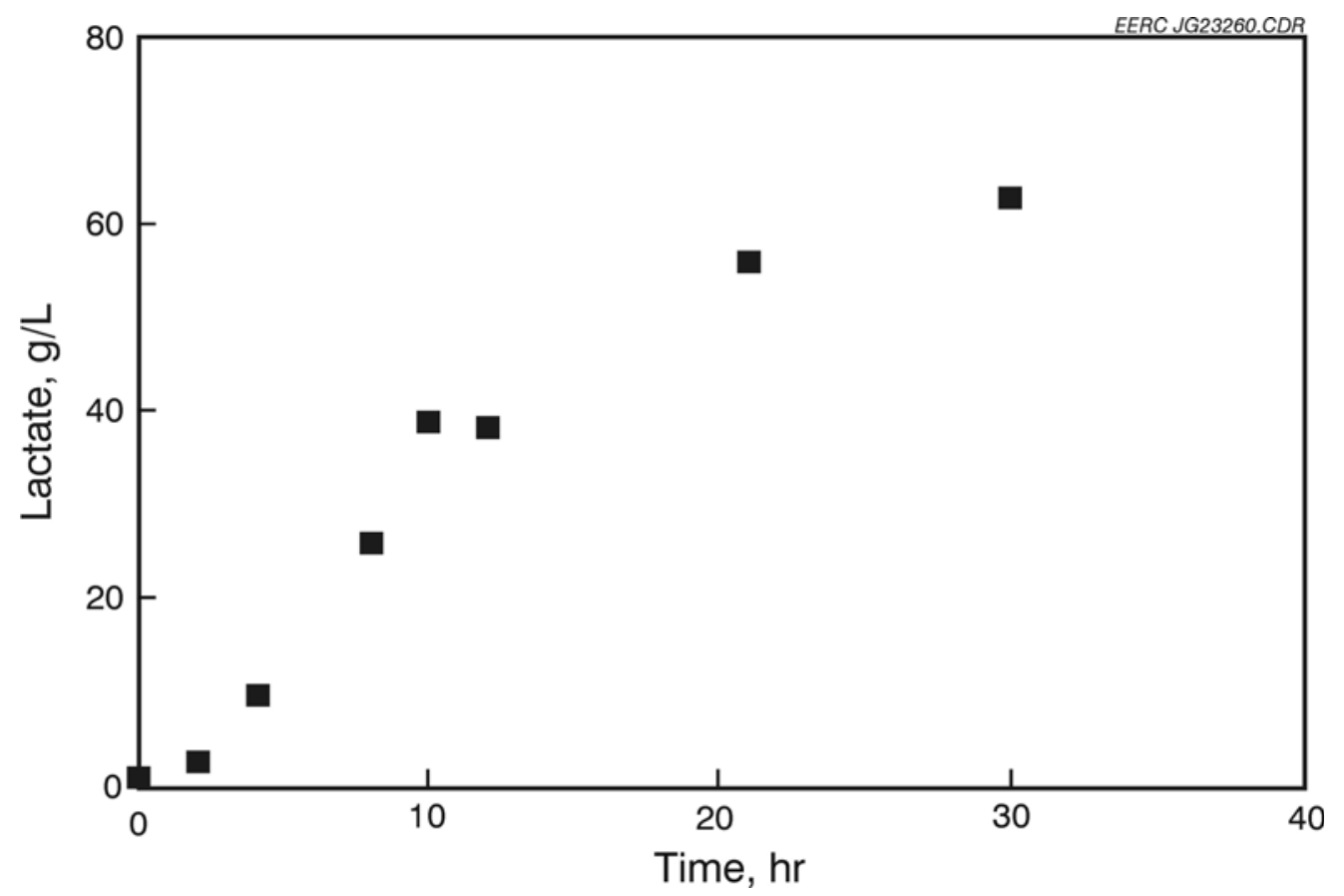

Figure 60. Production of fermentation acids by L. casei during the fermentation of glucose (nutrients added, initial glucose $177 \mathrm{~g} / \mathrm{L}$ ). 


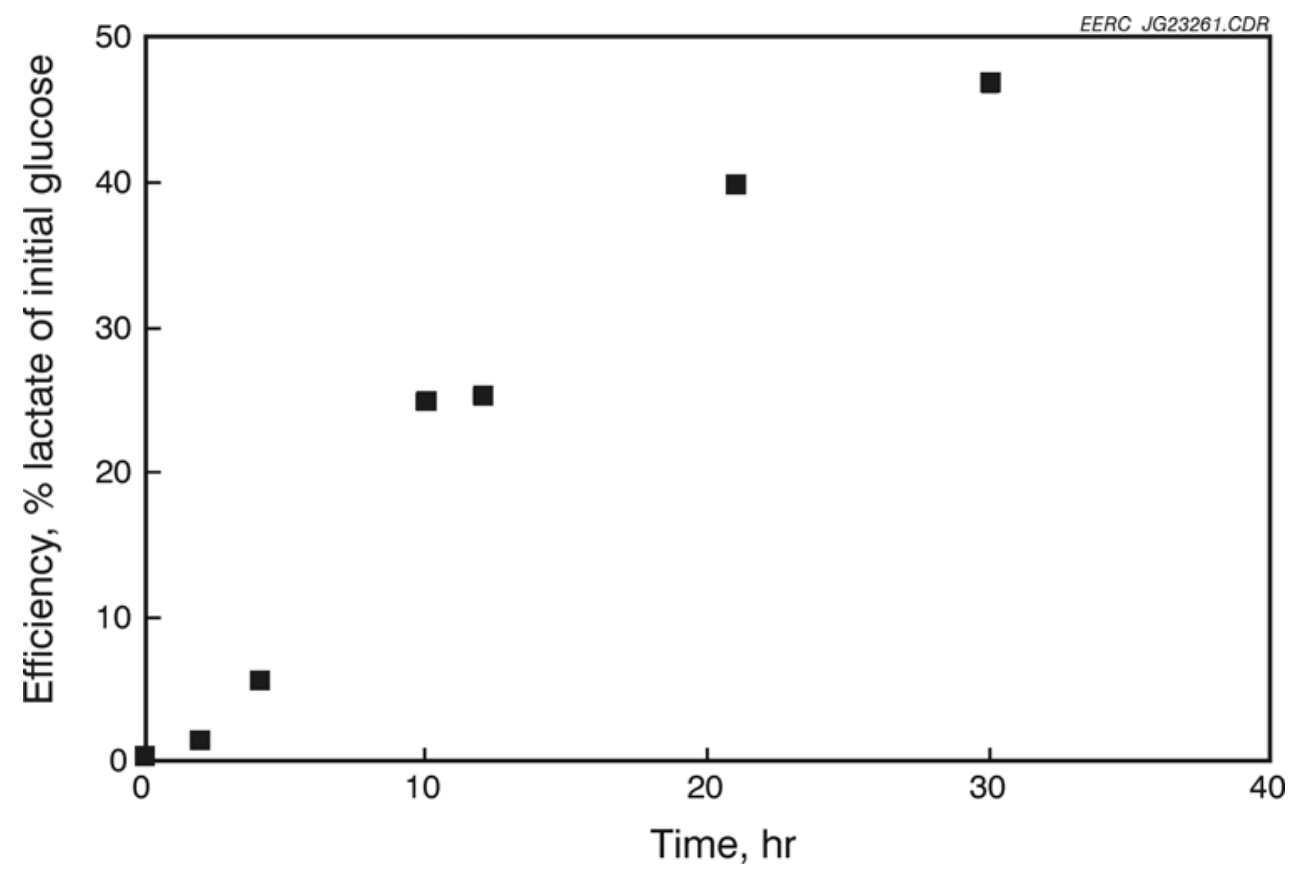

Figure 61. Efficiency of fermentation, expressed as the weight of lactic acid produced compared to the initial glucose concentration, during the fermentation of glucose by L. casei (nutrients added, initial glucose $177 \mathrm{~g} / \mathrm{L})$.

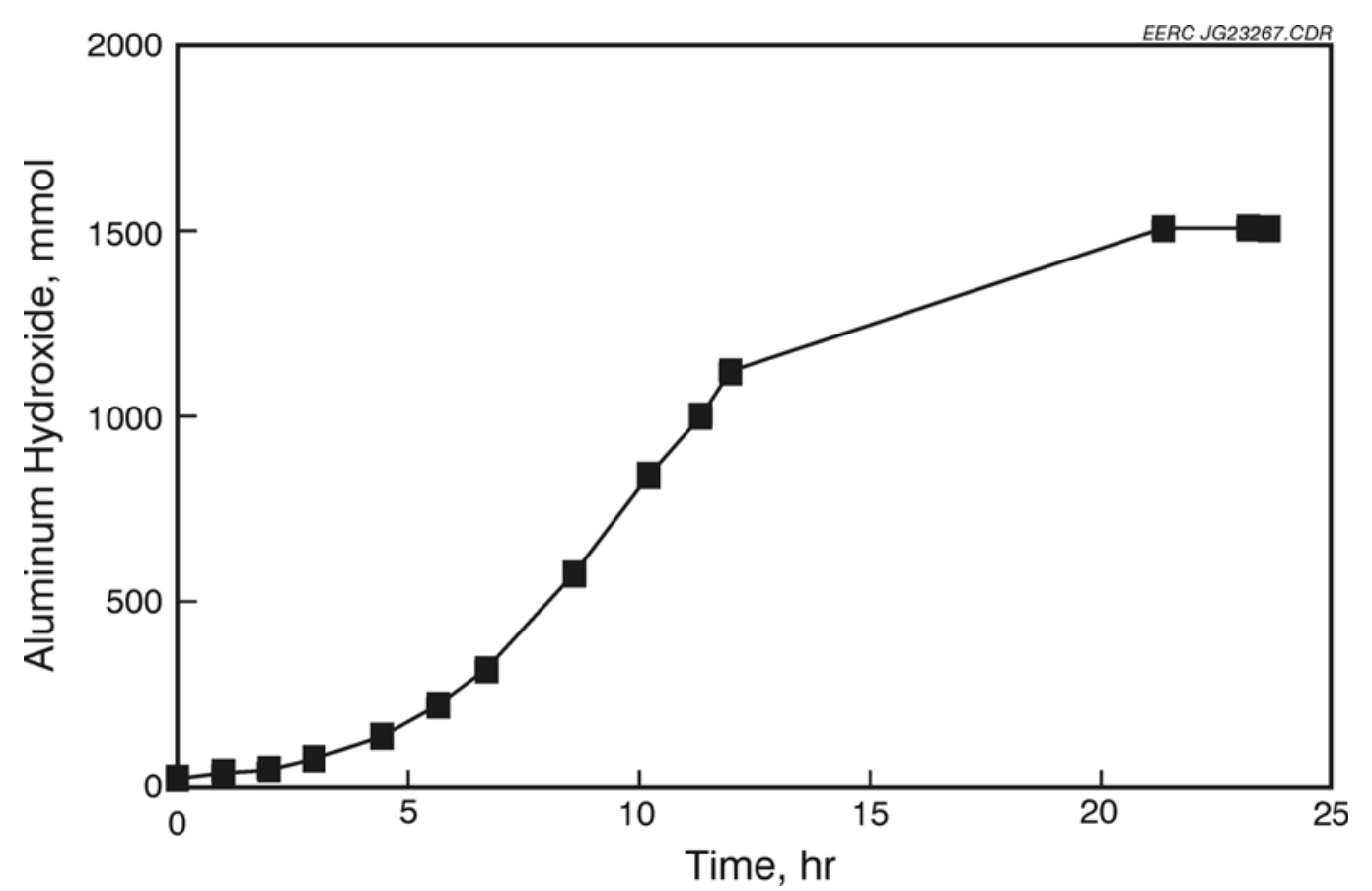

Figure 62. Cumulative consumption of $4.3 \mathrm{M}$ ammonium hydroxide during the fermentation of corn hydrolysate by E. coli FBR11 (nutrients added, initial glucose 112 g/L). 


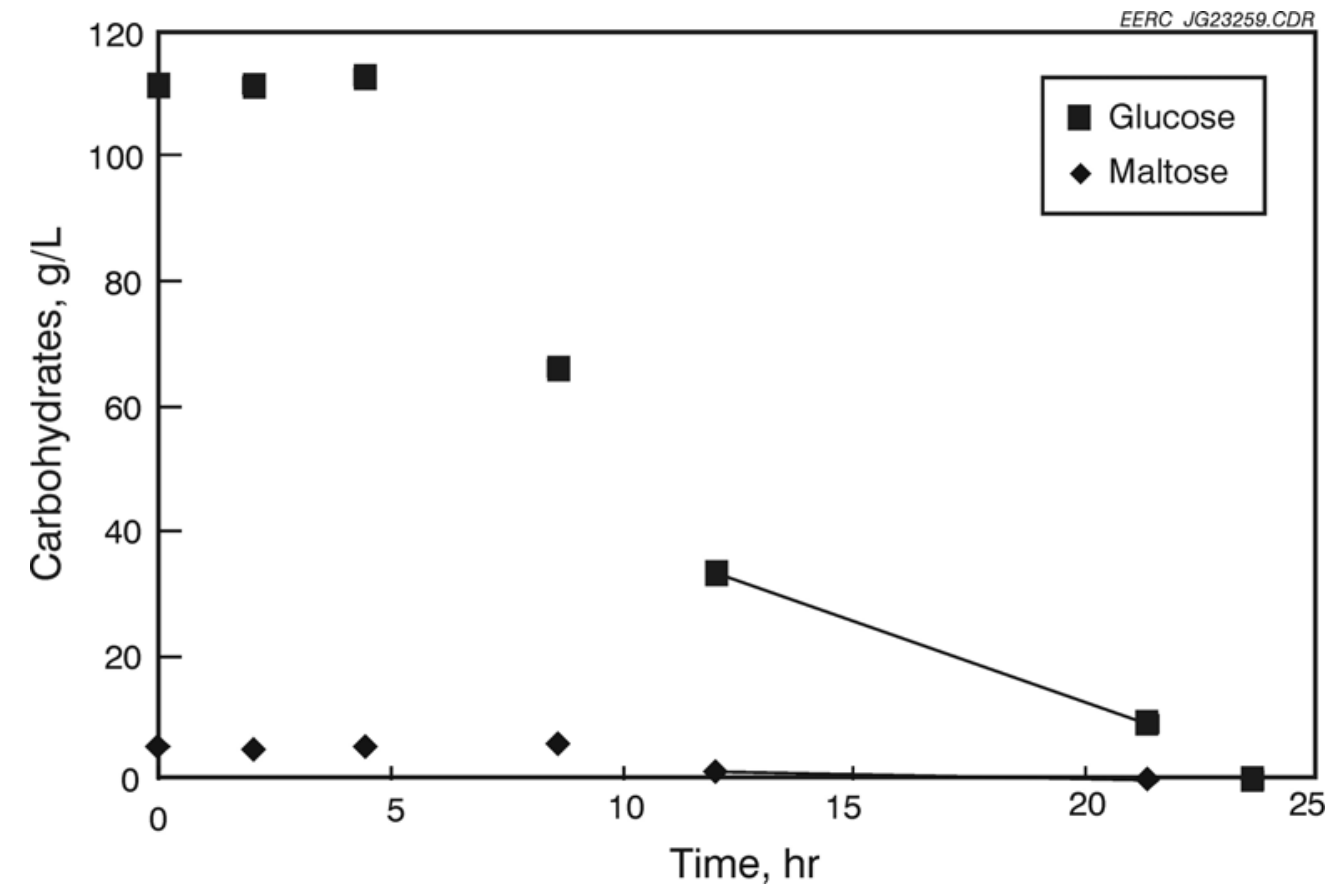

Figure 63. Consumption of carbohydrates in the fermentation of corn hydrolysate by E. coli FBR11 (nutrients added, initial glucose $112 \mathrm{~g} / \mathrm{L}$ ).

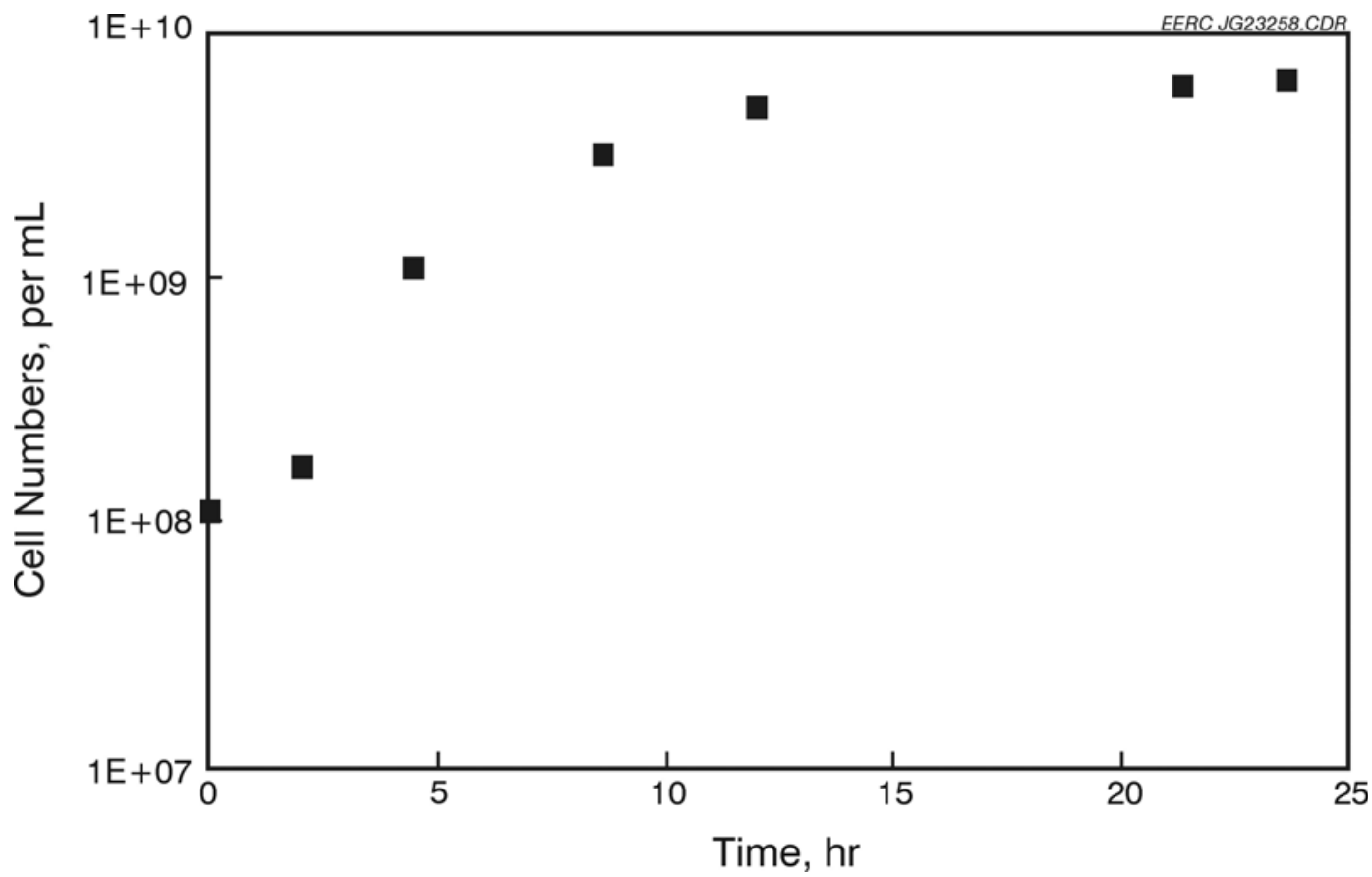

Figure 64. Total bacteria counts of the fermentation broth during the fermentation of corn hydrolysate by E. coli FBR11 (nutrients added, initial glucose $112 \mathrm{~g} / \mathrm{L}$ ). 


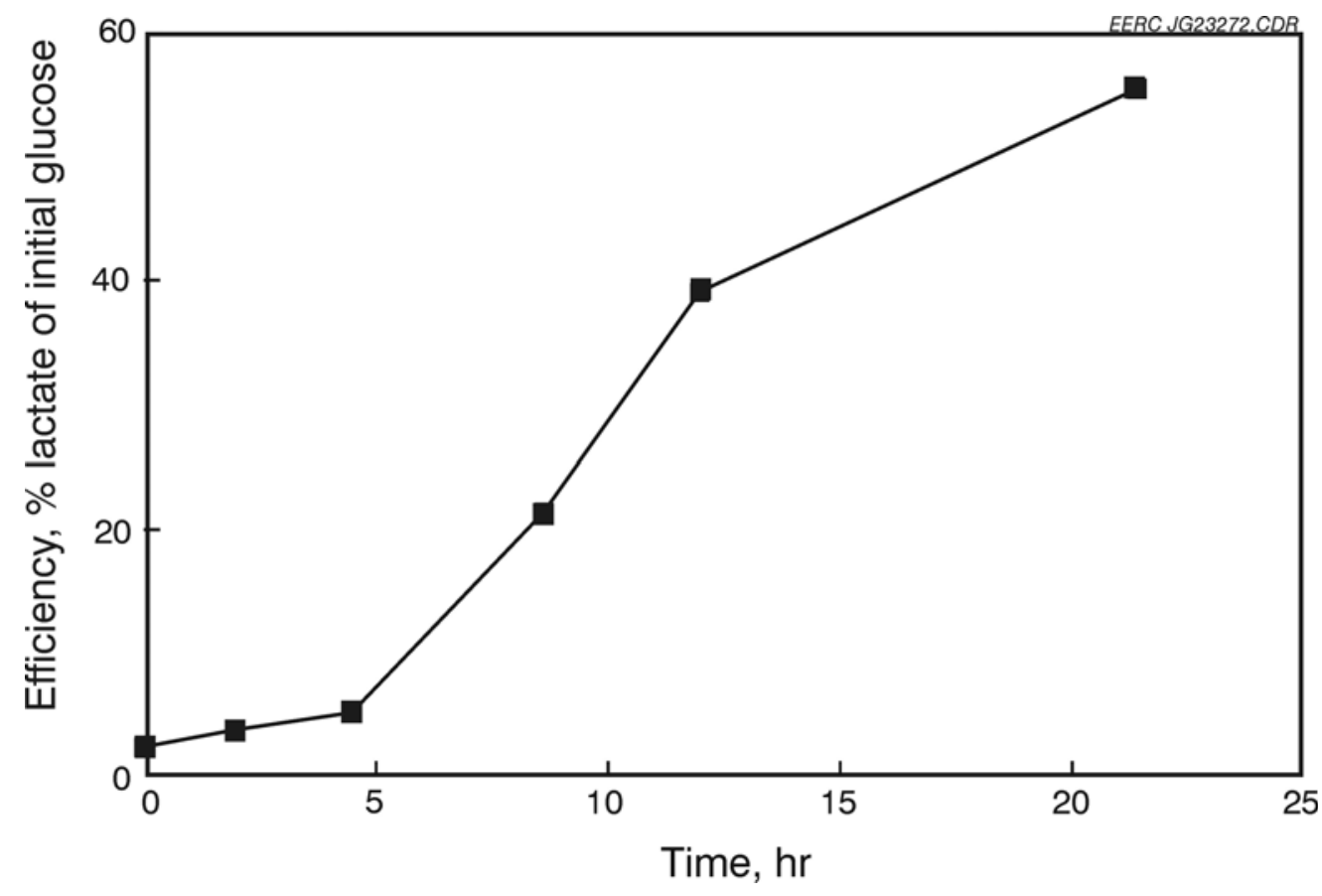

Figure 65. Production of fermentation acids by E. coli FBR11 during the fermentation of corn hydrolysate (nutrients added, initial glucose $112 \mathrm{~g} / \mathrm{L}$ ).

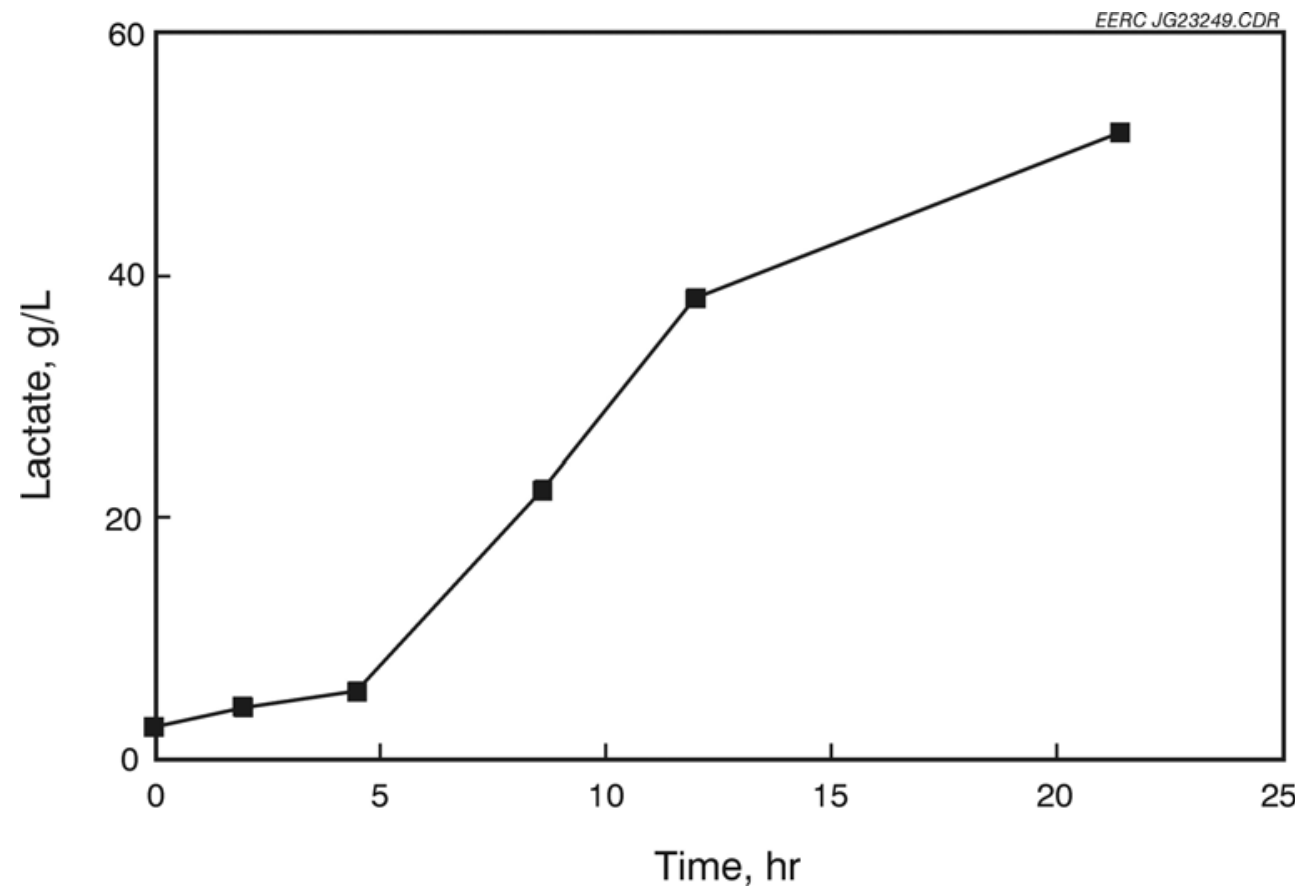

Figure 66. Efficiency of fermentation, expressed as the weight of lactic acid produced compared to the initial glucose concentration, during the fermentation of corn hydrolysate by $E$. coli FBR11 (nutrients added, initial glucose $112 \mathrm{~g} / \mathrm{L}$ ). 


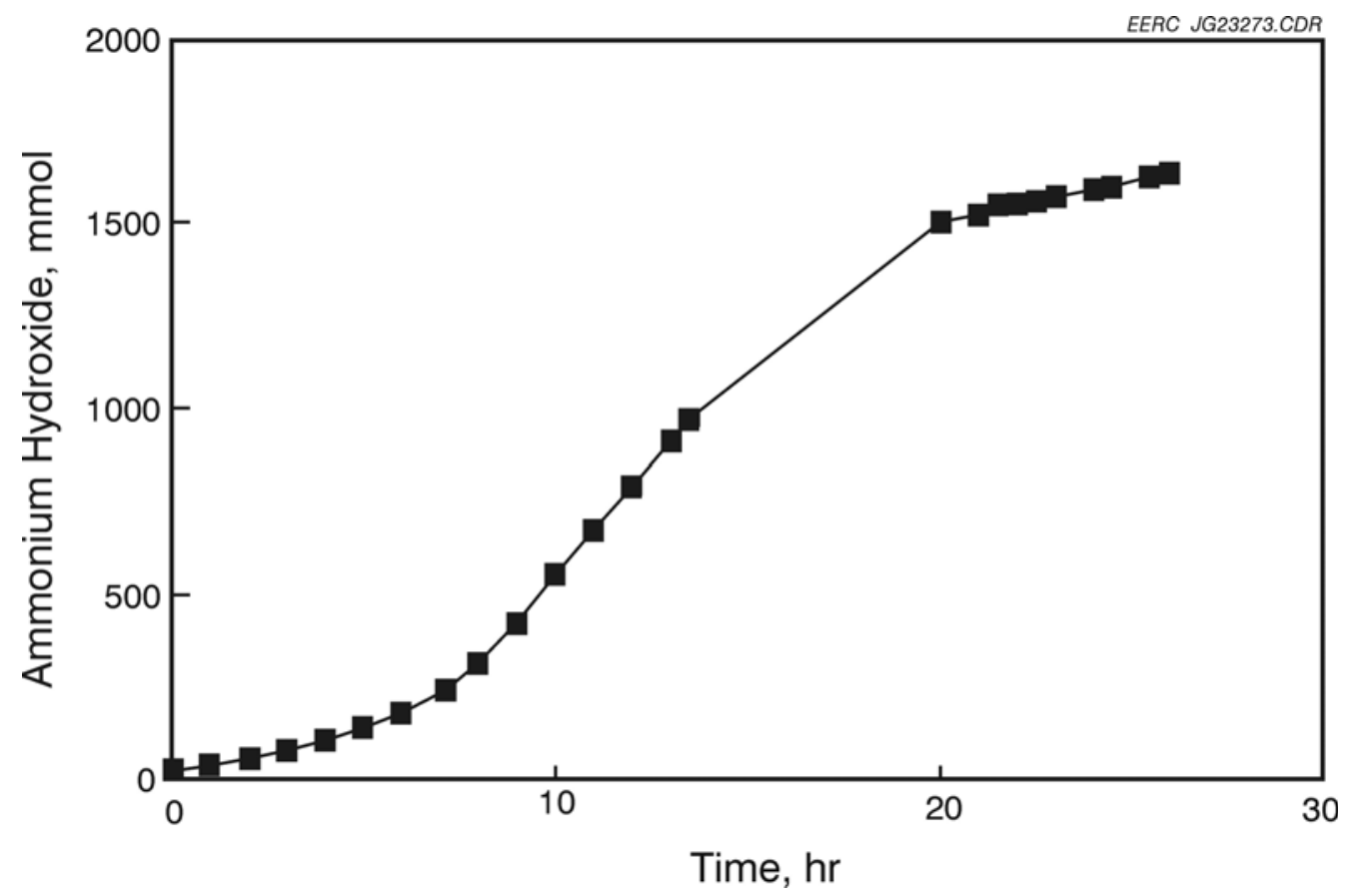

Figure 67. Cumulative consumption of $4.3 \mathrm{M}$ ammonium hydroxide during the fermentation of corn hydrolysate by E. coli FBR19 (nutrients added, initial glucose 124 g/L).

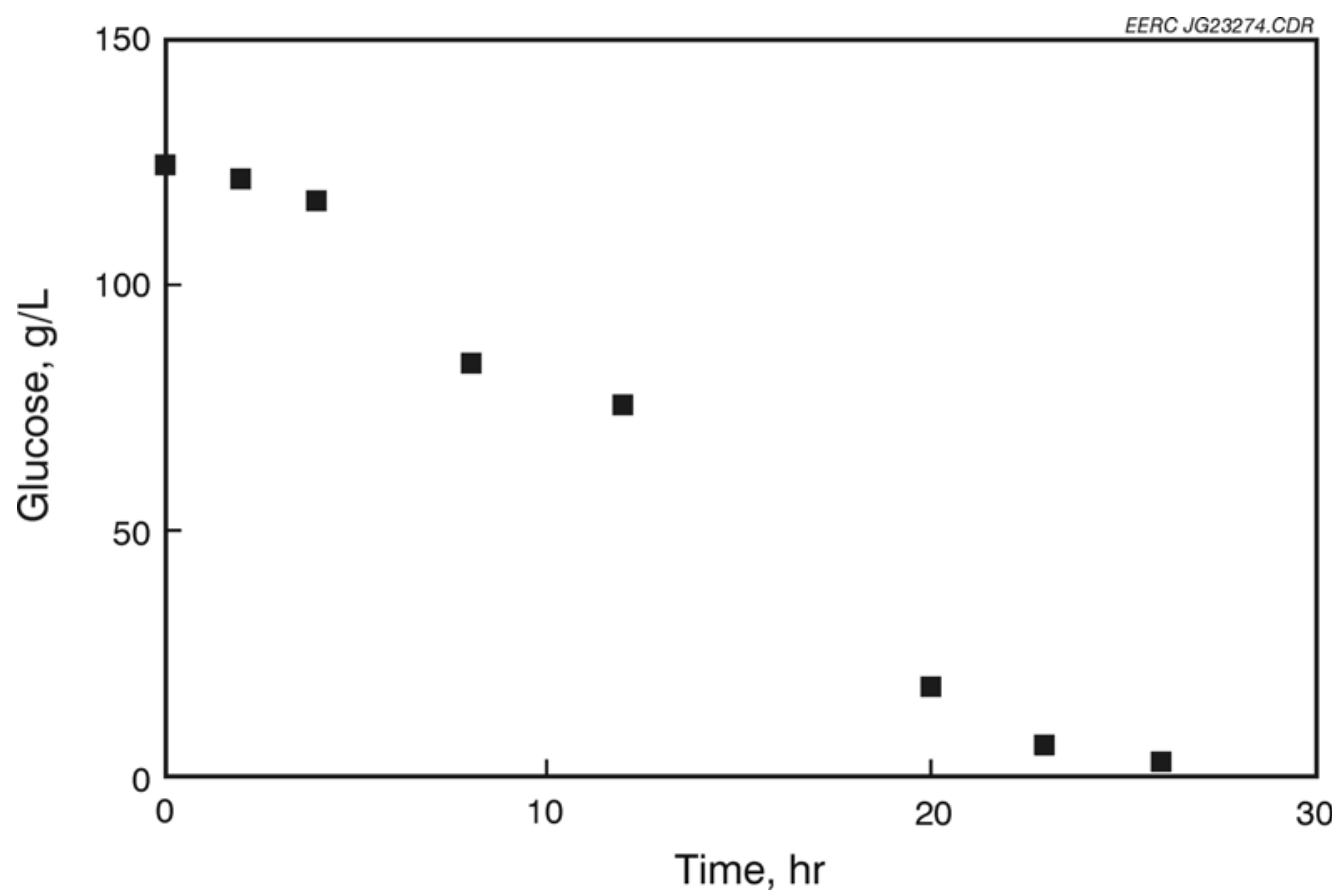

Figure 68. Consumption of carbohydrates in the fermentation of corn hydrolysate by E. coli FBR19 (nutrients added, initial glucose $124 \mathrm{~g} / \mathrm{L}$ ). 


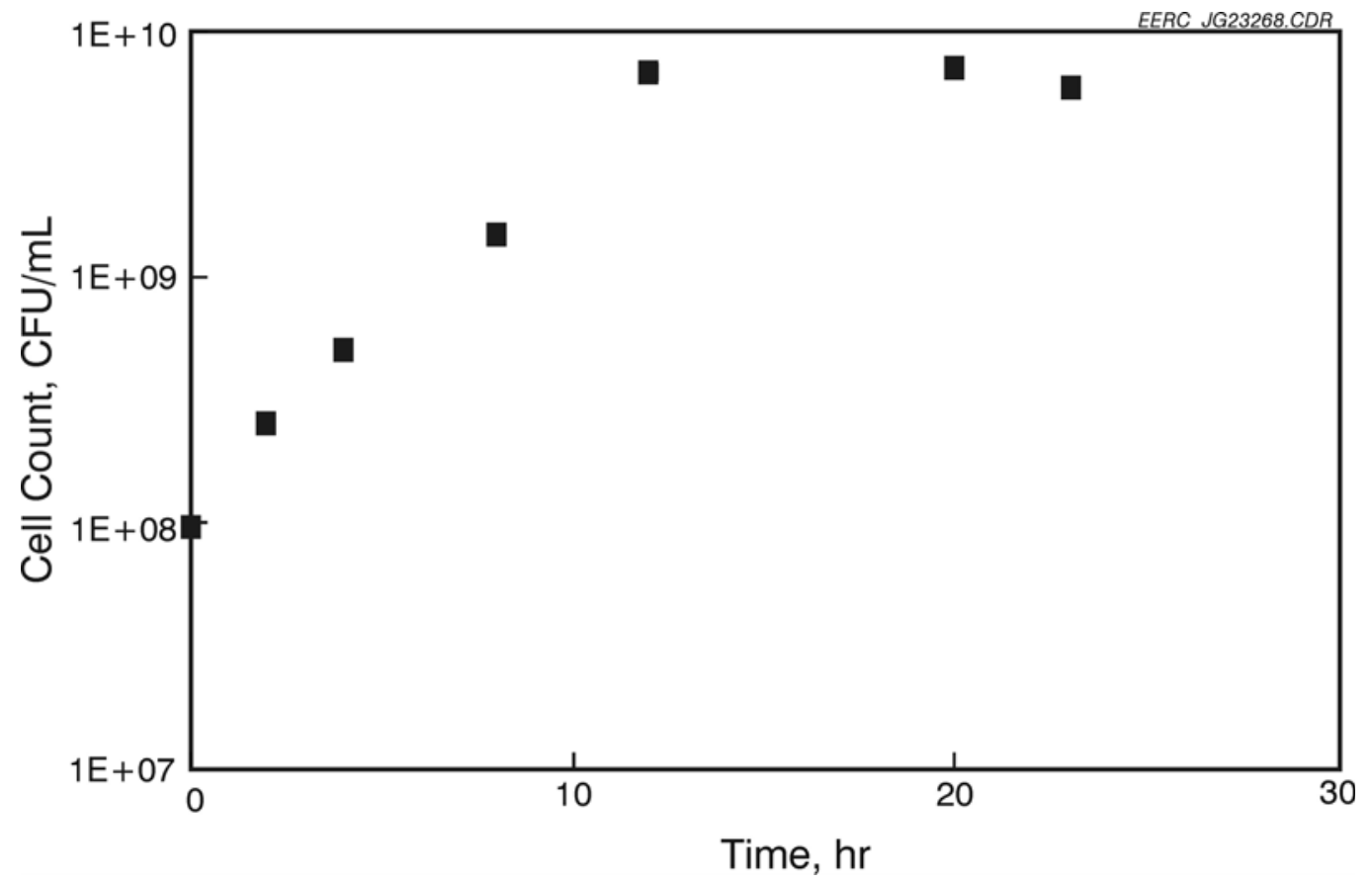

Figure 69. Total bacteria counts of the fermentation broth during the fermentation of corn hydrolysate by E. coli FBR19 (nutrients added, initial glucose $124 \mathrm{~g} / \mathrm{L}$ ).

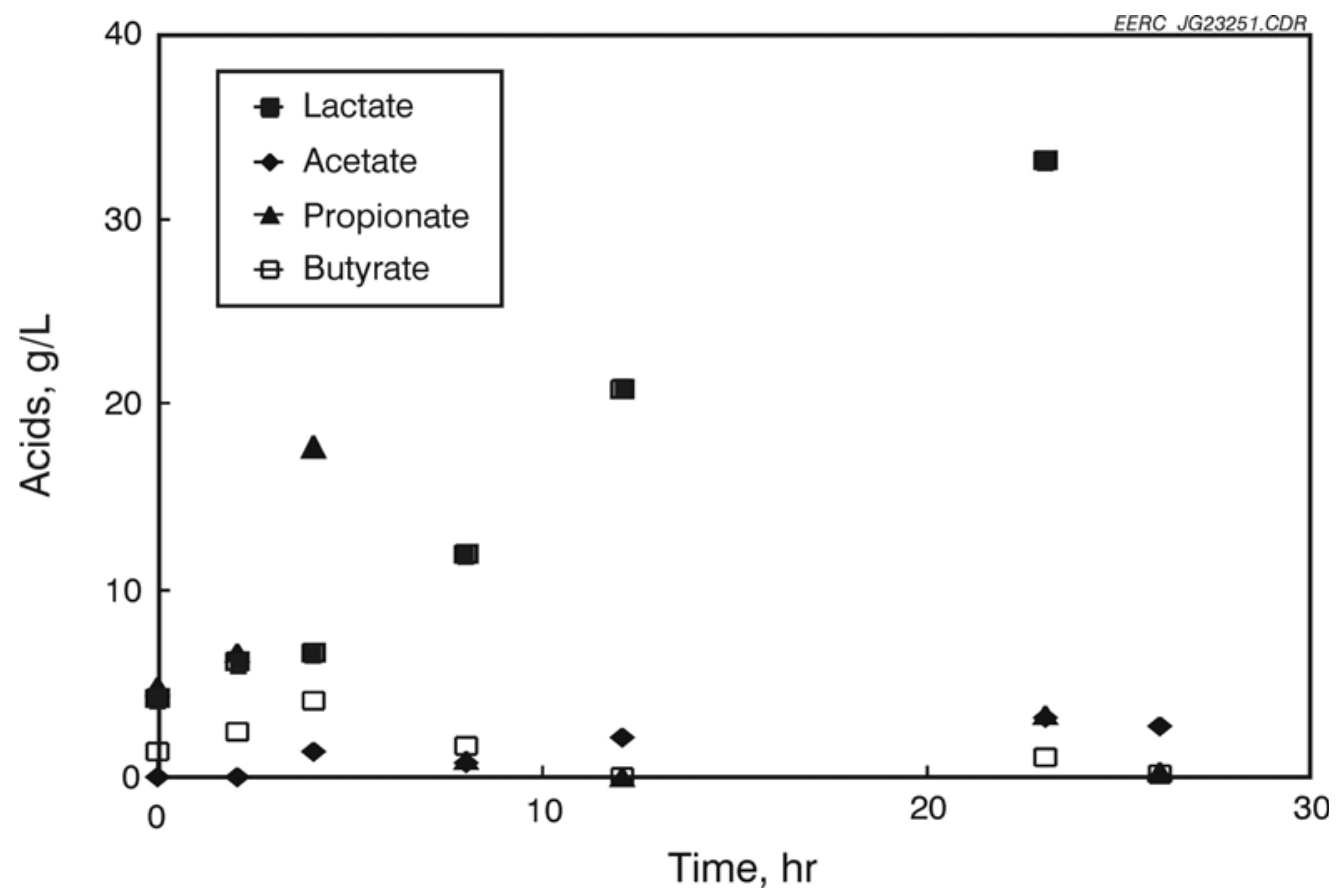

Figure 70. Production of fermentation acids by E. coli FBR19 during the fermentation of corn hydrolysate (nutrients added, initial glucose $124 \mathrm{~g} / \mathrm{L}$ ). 


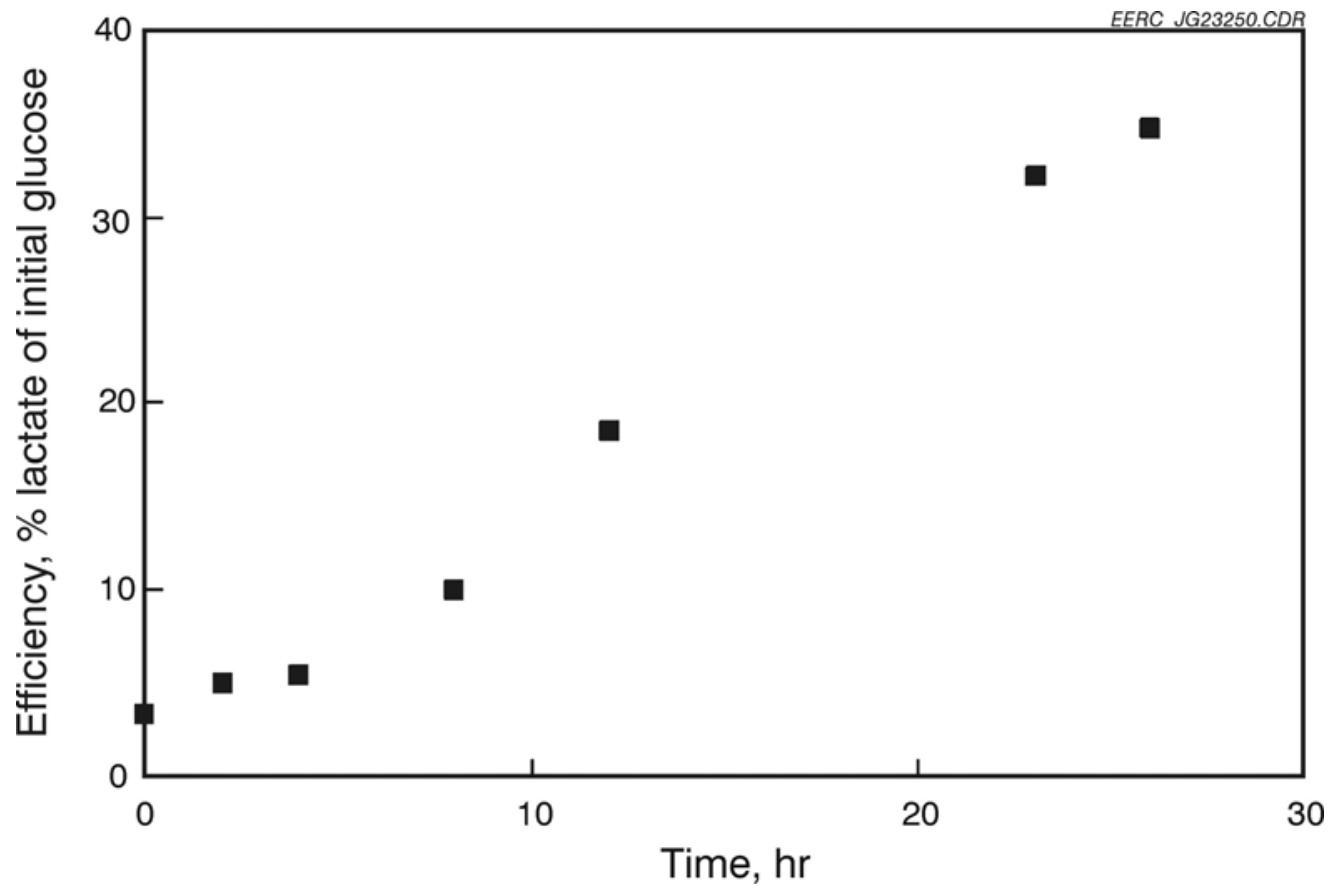

Figure 71. Efficiency of fermentation, expressed as the weight of lactic acid produced compared to the initial glucose concentration, during the fermentation of corn hydrolysate by $E$. coli FBR19 (nutrients added, initial glucose $124 \mathrm{~g} / \mathrm{L}$ ).

Table 23. Glucose and Lactic Acid Concentrations in the Fermentation Tests

\begin{tabular}{lccccc}
\hline Test & Bacterium & $\begin{array}{c}\text { Initial Glucose, } \\
\text { g/L }\end{array}$ & $\begin{array}{c}\text { Glucose } \\
\text { Consumed, g }\end{array}$ & $\begin{array}{c}\text { Final Lactic } \\
\text { Acid, g/L }\end{array}$ & $\begin{array}{c}\text { Lactic Acid } \\
\text { Produced, g }\end{array}$ \\
\hline 1 & L. delbruekii & 99 & 177.6 & 53 & 109 \\
2 & L. casei & 75 & 130 & 51.4 & 104 \\
3 & L. casei & 119 & 210 & 64.5 & 140.7 \\
4 & L. casei & 130 & 227 & 56.1 & 120.4 \\
5 & L. casei & 177 & 261 & 62.8 & 145 \\
6 & E. coli FBR 11 & 112 & 196 & 51.7 & 108.7 \\
7 & E. coli FBR 19 & 124 & 212 & 35.6 & 75.9 \\
\hline
\end{tabular}


Table 24. Lag Periods, Rate of Lactic Acid Production, and Time to Total Glucose Consumption in the Fermentations

\begin{tabular}{llccc}
\hline Test & Bacterium & Lag Period, hr & $\begin{array}{c}\text { Maximum Rate of Lactate } \\
\text { Production, g/L-hr }\end{array}$ & $\begin{array}{c}\text { Time to Consume All } \\
\text { Glucose, hr }\end{array}$ \\
\hline 1 & L. delbruekii & 2.8 & 3.65 & 25 \\
2 & L. casei & 0 & 4.04 & 12 \\
3 & L. casei & 2.4 & 5.84 & 14 \\
4 & L. casei & 0 & 1.02 & 54 \\
5 & L. casei & 2.5 & 4.46 & 35 \\
6 & E. coli FBR 11 & 3.5 & 4.31 & 12 \\
7 & E. coli FBR 19 & 1.1 & 1.77 & 24 \\
\hline
\end{tabular}

\section{Conclusions}

Several different strains of lactobacillus bacteria were evaluated for their ability to produce lactic acid from a corn hydrolysate feedstock used in ethanol production. Batch fermentation trials were conducted in a controlled environment with a laboratory-scale fermenter. The $\mathrm{pH}$ of the acid-producing fermentation reactions was controlled using an ammonium hydroxide solution. The result is the formation of an ammonium lactate solution. Ammonium salts are preferred over calcium salts as they are more easily processed in downstream unit operations (evaporation and esterification) and the ammonia can be recovered and recycled.

L. Casei was found to demonstrate relatively high rates of ammonium lactate production, along with the highest glucose conversion efficiencies. The conversion efficiencies observed during this testing were, however, somewhat less than that reported in the literature. These differences can be attributed to the use of a smaller innoculum size, where substrate needs for additional cell growth apparently resulted in lower lactate yield.

Effluent from the fermentation process needs to be further concentrated to reduce the amount of water prior to esterification. Fermentation broth was concentrated in evaporation trials by bubbling nitrogen gas through a sample of fermentation broth maintained at $70^{\circ} \mathrm{C}$ to produce a concentrated sample containing approximately $80 \%$ ammonium lactate. The concentrate samples were subsequently used in esterification test trials for the production of ethyl lactate esters (Subtask 3.1 of this report). 


\section{TASK 4.0 - MANAGEMENT AND STRATEGIC STUDIES}

\section{Results and Discussion}

An initial kickoff meeting was held in June 2002 where reporting requirements, midproject reviews, and laboratory quality assurance/quality control procedures were reviewed with project managers under the EERC Biomass Utilization project. In February 2003, a midproject review meeting was held at the EERC for all nine technical activities under this project. Quality Control manager at the EERC, Dave Brekke, was present at the meeting long with Associate Director Tom Erickson. Progress of all activities was reviewed, and reporting requirements were reviewed.

Bimonthly meetings of the EERC Center for Biomass Utilization ${ }^{\circledR}\left(\mathrm{CBU}^{\mathrm{SM}}\right)$ were organized over the course of this project and held at the EERC. These meetings were open to all in-house EERC personnel interested in biomass activities and served to update the progress of projects under the Year 2 Biomass Utilization project. Also, discussions were held regarding reporting requirements, deadlines, milestones, environmental issues, upcoming biomass-related conferences, and quality assurance/quality control practices. A short presentation by an EERC principal investigator on current biomass research was always part of these meetings as well, with some seminar titles and presenters including "Gasification of Industrial By-Products and Wastes in a Fluid-Bed Gasifier” by Dr. Michael Swanson, “The Dual Fermentation Biorefinery” by Dr. Edwin Olson, “Distributed Generation Biomass Gasifier Applications” by Darren Schmidt, "Evaluation of Lignin as a Boiler Fuel” by Chris Zygarlicke, "Biomass Gasification Integrated with SOFC Technology" by Phil Hutton, "Low-Intensity Treatment of Low-Rank Coals and Hybrid Wood to Obtain Liquid Fuel and Products of Added Value" by Melanie Jensen, and "Biomass Hydrogen Production from Thermophilic Bacteria” by Dr. John Gallagher.

Several reports were generated under this more administrative activity, including a federal assistance milestone report and hazardous substance plan in fulfillment of DOE contractual reporting requirements, quarterly progress reports and a milestone activity log, and a quality assurance/quality control midproject review form.

Strategic studies performed in this activity included attending meetings and preparing papers and presentations for conferences in order to publish technologies associated with these project activities. Discussions were also held with local industries interested in gasification biopower for their existing heating and power needs. Additional scoping activities were engaged to determine an interest in local biomass resources. In one case, a wheat straw board manufacturer had an interest in evaluating a biomass gasification system coupled with a reciprocal engine for power generation. In another case, biopower activities and the collocation of ethanol plants with utility generating stations were discussed with Alliant Energy, Manitoba Hydro, Great River Energy, Basin Electric Power Company, Arizona Public Service, Southern Company Services, Allegheny Power, and EPRI.

The end result of querying utilities and other groups on biopower opportunities for existing and future generating stations is summarized as follows: 
- Large coal-fired utilities are interested in the collocation of ethanol plants for selling power and steam to the ethanol plant. Utilities are also interested in burning lignin residues from lignocellulosic ethanol plants provided that the resource has been well characterized for its energy value, potential boiler impacts, and quantitative emissions.

- Large coal-fired utility power plants are interested in entertaining cofiring biomass for the purpose of lowering greenhouse gas emissions and for providing a renewable energy choice for constituents or establishing green tags or credits as long as the cost for obtaining biomass fuels does not exceed current coal costs.

- Large coal-fired utility power plants are interested in biomass cofiring as long as the cost for retrofitting the boiler or coal yard equipment to store, handle, process, and inject the biomass is not too exorbitant.

- Utilities or other entities that own or operate smaller ( $<20 \mathrm{MW}$ ) heat or power systems find that a consistent supply and a quality biomass resource are attractive options to cofire with or replace fossil fuels. Similar concerns as for larger utilities remain, such as the cost for the fuel being considerably higher than the current fuel and capital investment costs being too high to convince fuel procurement specialists and lending institutions.

Another strategic study involved evaluating an existing biorefinery process developed at the EERC for application to a fiberboard industry process. The EERC biorefinery process employs direct esterification of concentrated ammonium salts of organic acids. This offers a more simple and efficient processing option. The dual fermentation biorefinery, as it is called, is a proprietary method that involves direct esterification of ammonium salts to form methyl and ethyl esters in high yield. This process is able to produce lactate esters for solvents and intermediates for high-value polylactide (PLA) fibers or other esters for fuel additives, solvents, and chemical intermediates. The concept was discussed with officials from AgriTek (Fargo, North Dakota), a fiberboard developer, to see if this type of biorefinery technology would be of interest to small companies. AgriTek had interests in developing biorefinery products such as value-added chemicals and liquid fuels from residues produced in a medium-density fiber (MDF) and microfiber strand board factory that uses wheat straw.

A strategic study involving exchanging information on integrated biopower and bioproduct development occurred with an institute from the Imperial Valley in California. Dr. Paul Sebesta, Director of the Desert Research \& Extension Center (DREC) in El Centro, California, visited the EERC in August 2003 and described potential biopower and bioproduct developments in the Imperial Valley region of southern California. Since 1997, research has been conducted at the University of California's DREC into the feasibility of growing sugarcane in the low desert. While the initial goal was to use sugarcane as a sugar crop, it is now being viewed as an industrial crop for the production of renewable energy and other bioproducts. With a number of firms interested in developing sugarcane projects in the Imperial Valley, the university, project proponents, and Imperial County representatives are now working to develop this area as a renewable energy "ecopark" and "ecocommunity." Paul Sebesta is the director of the DREC and provided an update on potential renewable bioproduct development being planned for the 
Imperial Valley. Dr. Sebesta was interested in DOE technologies being developed in the EERC Biomass Utilization project, including the CSR technology which would aid in processing sugarcane stalks, leaves, tops, and leafy trash for conversion processes.

In other strategic study-type interactions, a visit was made to North Dakota State University (NDSU) in Fargo, North Dakota, in December 2003, to exchange information on biomass research with NDSU's Dean of Research, Dr. Phillip Boujouk. NDSU is a land-grant college with extensive programs in agricultural technologies, including biomass utilization. Also, a visit was made to the Western Research Institute to trade information on biomass-related projects.

Several papers were presented to promote some of the activities being funded in this DOE project. A paper and presentation on rice straw lignin cofiring with coal were delivered at the Bioenergy 2002 Conference in September 2002 in Boise, Idaho. The Renewable Fuels Association National Ethanol Conference was attended in February 2003 in Scottsdale, Arizona. A paper was presented and two sessions on biomass coordinated at the 28th International Technical Conference on Coal Utilization and Fuel Systems in March 2003 in Clearwater, Florida. The paper was written on gasification of wood saw dust, sugar beet pulp and tailings, and black liquor in a small 1- to 4-lb/hr fluid-bed gasification reactor to determine optimum conditions for product gas. The conference was well attended, and the technical presentations were excellent. A paper entitled Effects of Biomass Blending on Combustion Ash was presented at the American Chemical Society International Conference and Symposium in New York City in September 2003. The paper focused on fundamental mechanisms of ash formation and deposition associated with biomass cofiring with coal.

Work was also done to prepare for and facilitate the Biomass for Heat \& Power Workshop II held on November 13, 2003, at the EERC. The conference was a success with 80 participants from the United States, Mexico, and several Canadian provinces. During Renewable Energy Week at the EERC (November 10-14, 2003), a group of 40 Canadians representing Manitoban industry, government, universities, farmers, and private companies toured the EERC and were given short presentations on utilizing biomass as a resource for producing marketable products, fuels, and power. Also during that week, attendees of the Governor's Ethanol Coalition Meeting, which was held on November 12-13, were given information on biomass-to-ethanol opportunities. Seminars entitled "Biofuels 101: Ethanol" and "Biodiesel and Biopower 101" were also presented at the Renewable Energy Summit October 28-29, 2003, in Mandan, North Dakota.

\section{Conclusions}

The EERC CBU Year 2 project produced a wealth of technological results in the biorefining of biomass to valuable esters, ethanol use in small engines, drying and processing biomass for introduction into combustion or gasification systems, producing hydrogen using ethanol and using bacteria that break down biomass, cofiring herbaceous and woody biomass in a next-generation high-efficiency advanced power system, and utilizing waste oil to produce biodiesel. Over 20 papers were published through this work, and information dissemination 
through meetings, conferences, workshops, and publications gave credence to the value of DOEfunded research and development.

\section{REFERENCES}

1. Selle, S.J.; Hajicek, D.R.; Mann, M.D.; Grewal, N.S. Controlled Spontaneous Reactor System. U.S. Patent 5,546,875, 1996.

2. Hajicek, D.R.; Mann, M.D.; Moe, T.A.; Selle, S.J. Development of a Fluidized-Bed Coal Pretreatment System for Coupling to a Fluidized-Bed Boiler. Presented at the 14th International ASME Conference on Fluidized-Bed Combustion, Vancouver, BC, May 11-14, 1997.

3. Benemann, J.R. Hydrogen Production by Microalgae. J. Appl. Phycol. 2000, 12, 291-300.

4. Boone, D.R. Thermodynamics of Catabolic Reactions in the Anaerobic Digestor. In Biotechnological Advances in Processing Municipal Wastes for Fuels and Chemicals; Antonopoulos, A.A., Ed.; Noyes Data Corporation: Park Ridge, NJ, 1987; pp 85-96.

5. Van Ooteghem, S.A.; Beér, S.K.; Yue, P.C. Hydrogen Production by the Thermophilic Bacterium, Thermotoga Neapolitana. In Proceedings of the 2001 DOE Hydrogen Program Review; 2001, NREL/CP-570-30535.

6. Belkin, S.; Wirsen, C.O.; Jannasch, H.W. A New Sulfur-Reducing, Extremely Thermophilic Eubacterium from a Submarine Thermal Vent. Appl. Environ. Microbiol. 1986, 51, 1180-1185.

7. Heyer, N.I.; Woodward, J. Efficient Hydrogen Production Using Enzymes of the Pentose Phosphate Pathway. In Proceedings of the 2001 DOE Hydrogen Program Review; 2001, NREL/CP-570-30535.

8. Baltz, R.H. Mutagenesis in Streptomyces spp. In Manual of Industrial Microbiology and Biotechnology; Demain, A.L.; Solomon, N.A., Eds.; American Society for Microbiology, Washington, D.C., 1986; pp 184-197.

9. ASTM C618-01. Standard Specification for Coal Fly Ash and Raw or Calcined Natural Pozzolan for Use as a Mineral Admixture in Concrete. ASTM International.

10. ASTM C618-03. Standard Specification for Coal Fly Ash and Raw or Calcined Natural Pozzolan for Use as a Mineral Admixture in Concrete. ASTM International.

11. Hollman, G.G.; Steenbruggen, G.; Janssen-Jurkovicova, M. A Two-Step Process for the Synthesis of Zeolites from Coal Fly Ash. Fuel 1999, 78 (10) 1225-1230. 
12. Mandragon, F.; Rincon, F.; Sierra, L.; Escober, J.; Ramirez, J.; Fernandez, J. New Perspective of Coal Ash Utilization: Synthesis of Zeolite Material. Fuel 1990, 69, 4781-4786.

13. Querol, X.; Alastuey, A.; Turiel, J.L.F.; Soler, A.L. Synthesis of Zeolites by Alkaline Activation of Ferro-Aluminous Lagoon Ash. Fuel 1995, 74 (8), 1225-1231.

14. Kolay, P.K.; Singh, D.N. Effect of Zeolitization on Physicochemico-Mineralogical and Geotechnical Properties of Lagoon Ash. Can. Geotech. J. 2001, 38, 1105-1112.

15. Virta, R.L. Zeolites -2000. In U.S. Geological Survey Minerals Yearbook - 2000, 85; pp 1-5.

16. Energy Bureau Iowa Department of Natural Resources. Ethanol. www.state.ia.us/dnr/energy/programs/ethanol (accessed 2003).

17. Cameron, K. Parallel Paths - Two-Stroke or Four-Stroke Engines. Snowtech Magazine 2002, Sept, 74-77.

18. Wright, C.; White, J. Development and Validation of a Snowmobile Engine Emission Test Procedure. In Proceedings of the International Off-Highway \& Powerplant Conference and Exposition; Milwaukee, WI, Sept 14-16, 1998, SAE 982017.

19. Stenroos, S-L.; Linko, Y-Y.; Linko, P. Production of L-Lactic Acid with Immobilized Lactobacillus Delbruekii. Biotechnol. Lett. 1982, 4, 159-164.

20. Hujanen, M.; Linko, S.; Linko, Y-Y.; Leisola, M. Optimization of Media and Cultivation Conditions for L(+)(S)-Lactic Acid Production by Lactobacillus Casei NRRL B-441. Appl. Microbiol. Biotechnol. 2001, 56, 126-130.

21. Dien, B.S.; Nichols, N.N.; Bothast, R.J. Recombinant Escherichia Coli Engineered for Production of L-Lactic Acid from Hexose and Pentose Sugars. J. Indust. Microbiol. Biotechnol. 2001, 27, 259-264.

22. Dien, B.S.; Nichols, N.N.; Bothast, R.J. Fermentation of Sugar Mixtures Using Escherichia Coli Catabolite Repression Mutants Engineered for Production of L-Lactic Acid. J. Indust. Microbiol. Biotechnol. 2002, 29, 221-227.

23. Litchfield, J.H.. Microbiological Production of Lactic Acid. Adv. Appl. Microbiol. 1996, 42, 45-95. 


\title{
APPENDIX A
}

\section{SUBTASK 1.4 - DEVELOPMENT OF MANAGEMENT OPTIONS FOR BIOMASS COMBUSTION BY-PRODUCTS}

\author{
BIOMASS ASH: \\ AN ANNOTATED BIBLIOGRAPHY
}




\section{Biomass Ash: An Annotated Bibliography}

1. Baxter, L. Biomass-Coal Cofiring: Implications for Ash Disposition. Presented at the American Coal Ash Association-Utility Solid Waste Activities Group Workshop, Nashville, TN, June 5, 2001.

This slide show consists mostly of graphs on subjects including differences between coal and biomass, biomass available for cofiring, and fuel relationships.

Keywords: cofiring, coal ash, alkali, $\mathrm{K}, \mathrm{Ca}, \mathrm{Na}, \mathrm{CO}_{2}$, wood, concrete, $\mathrm{C} 618$

2. Brunner, T.; Dahl, J.; Obernberger, I.; Pölt, P. Chemical and Structural Analyses of Aerosol and Fly-Ash Particles from Fixed-Bed Biomass Combustion Plants by Electron Microscopy. In Proceedings of the 1st World Conference on Biomass for Energy and Industry; Sevilla, Spain, June 2000; James \& James Ltd., Ed.: London, UK, 1991-1995; Vol. II.

This paper explores the mechanisms governing the formation of coarse fly ash and aerosol particles in biomass combustion processes. Results are discussed from analyses by scanning electron microscopy and energy dispersive x-ray spectrometry performed on aerosol and fly ash samples from the flue gas of biomass combustion units. A comparison of the results of analysis of samples from test runs with different kinds of biomass fuels shows the remarkable differences in shape and composition of the submicron and coarse mode of the particulates. While the submicron particles mainly consist of $\mathrm{K}, \mathrm{Na}, \mathrm{S}, \mathrm{Cl}$, and heavy metals such as $\mathrm{Zn}$ and $\mathrm{Pb}$, the main compounds of the coarse mode are refractory species like $\mathrm{Ca}$, Si, Mg, and Al. Submicron particles are spheres or crystals, while the coarse fly ash particles are amorphous (if molten) or consist of a grid built up by refractory species on which smaller particles agglomerated.

Keywords: fly ash, aerosol, electron microscopy, combustion, testing, submicron particles

3. Brunner, T.; Obernberger, I. New Technologies for $\mathrm{NO}_{\mathrm{x}}$ Reduction and Ash Utilization for Biomass Combustion Plants. In Proceedings of the 9th European Bioenergy Conference; JOULE THERMIE 95 Demonstration Project; Elsevier Science Ltd., Ed.: Oxford, UK; Vol. 2, pp 1269-1275.

The technologies described in this paper are aimed at increasing the sustainability of biomass heating plants. In comparison to oil or gas, biomass combustion leads to higher $\mathrm{NO}_{\mathrm{x}}$ emissions. Previous research has shown that "air staging" is a useful way to reduce these $\mathrm{NO}_{\mathrm{x}}$ emissions efficiently. Therefore a new-computer-aided process control system for biomass grate furnaces has been developed. Besides the flue gas, the second product stream of combustion processes, the ash, also contains environmentally harmful substances, the heavy metals. By separating a side stream rich in heavy metals, a major part of the ashes produced can be recycled as secondary raw materials with liming and fertilizing effects. The aim of this technology is to close the elementary cycles of nature (soil/nutrient-root/tree-combustion-ash/fertilizer-soil), which are disturbed by 
the deposition of heavy metals on the forest ecosystem by environmental pollution.

Keywords: combustion, $\mathrm{NO}_{\mathrm{x}}$, reduction, air staging, flue gas recirculation, fractionated heavy metal separation, utilization, environment

4. Buder, M. The World of Wood Flyash. Presented at the ECAP Working Session on the Utilization of Flyash from Wood-Fired Boilers, Nov 27 - Dec 2, 1995.

This slide show presents fly ash opportunities, nature and source of fly ash, hog fuel boilers and their fuel, fly ash handling and disposal, alternatives to disposal, and wood fly ash characteristics.

Keywords: wood, fly ash, hog fuel boilers, characterization, disposal, grate boiler

5. Costello, R. Biomass Cofiring Offers Cleaner Future For Coal Plants. Power Eng. 1999, Jan, 45-48.

This article discusses cofiring technology, environmental benefits of cofiring, cofiring economics, and the future of cofiring biomass. It also includes a table of biomass cofiring plants and gives actual examples of the three stages of cofiring experience: long-term operation, just getting under way, and testing.

Keywords: cyclone boiler, wood, cofiring, pulverized coal boiler, $\mathrm{SO}_{2}, \mathrm{NO}_{\mathrm{x}}, \mathrm{CO}_{2}$

6. C.T. Donovan Associates, Inc.; BFI Organics, Inc. Innovative End Uses For Wood Ash from Construction and Demolition Waste; Final Report 00-15; Burlington, VT; Portsmouth, NH, June 1998; Vol. 1: Study Results.

The primary objective of this project was to test the physical, chemical, and environmental characteristics of flowable fill mixes containing different combinations of construction and demolition (C\&D) wood ash and concrete. A secondary objective was to evaluate the potential for controlling soil acidity by land-application of this ash. Ash samples were obtained from a series of test burns in which clean wood was mixed with from $11 \%$ to $31 \%$ of different types of treated wood, including creosote-treated wood, pentachlorophenol-treated wood, coal combustion ash (CCA)-treated wood, particleboard/plywood, and processed, and mixed C\&D wood. Metal content and leaching were among the tests performed on these ash samples.

Keywords: wood, creosote-treated, pentachlorophenol-treated, CCA-treated, particleboard/plywood, construction and demolition (C\&D or C/D), flowable fill, concrete, liming agent, regulations, testing

7. Dahl, J.; Oberneberger, I. Thermodynamic and Experimental Investigations on the Possibilities of Heavy Metal Recovery from Contaminated Biomass Ashes by Thermal Treatment. In Proceedings of the 10th European Bioenergy Conference; Würzburg, Germany, June 8-11, 1998; C.A.R.M.E.N. (ed): Rimpar, Germany. 
In the framework of the EC-JOULE project, "Sustainable Ash Utilization" research is focused on the possibilities of heavy metal recovery from contaminated filter fly-ashes in order to be able to recycle the decontaminated ashes on soils and use the metals in industrial processing. Thermal ash treatment under controlled conditions was applied to achieve this objective. Glowing contaminated ashes under controlled temperature and gas atmosphere conditions offer the possibility to vaporize the ecologically relevant heavy metals (Cd, Zn) and subsequently separate their condensed species by appropriate measures.

The main emphasis of this investigation is placed on identifying influencing parameters and explaining them with the help of the theoretical calculations. The results of these studies will help to establish a theory on the behavior of heavy metals and other important ash elements (like $\mathrm{K}, \mathrm{S}, \mathrm{Cl}$ ) in high-temperature atmospheres. The highest percentages of heavy metal reduction by thermal ash treatment are achieved in a reducing atmosphere, which is created or enhanced by organic carbon in the ashes.

Keywords: bottom ash, cyclone fly ash, filter fly ash, heavy metal, Cd, Zn, wood, thermal treatment, testing

8. Environmental Resource Services, Inc. Conversion of Biomass to Energy; Final Report for Tennessee Valley Authority Contract No. TV-01418W; Environmental Resource Services, Inc.: Anniston, AL, Oct 31, 1998 (table of contents and executive summary only)

The Anniston biomass conversion facility was originally intended to be a fuel production facility. Various potential customers for bio-oil were identified in the Anniston area, and discussions were held regarding sales of this product as a fuel. Unfortunately, fossil fuel oil prices have dropped significantly in the last two years; consequently, bio-oil as a fuel could not be sold at a price high enough to support the project economics. Thus products other than fuel oil must be sold to permit the Anniston project to proceed. The potential use of a portion of the biooil as natural resin (NR), a replacement for a portion of the phenol in certain resins, has been identified. Discussions with possible customers for NR and product testing are ongoing. It is hoped that even though the project cannot proceed in the context of the Tennessee Valley Authority (TVA) grant, an ENSYN RTP ${ }^{\mathrm{TM}}$ project in the vicinity of Anniston can be completed eventually.

Keywords: Alabama, bio-oil, natural resin, wood, TVA

9. Farris, M.; Paisley, M.A.; Irving, J.; Overend, R.P. The Biomass Gasification Process by Battelle/Ferco: Design, Engineering, Construction, and Startup. In Proceedings of BioEnergy 98, Madison, WI, Oct 4-8, 1998.

The ratio of electricity demand to thermal needs in the processing plant have risen considerably; replacement of current boiler and steam turbine technology by gasifier and gas turbine combined cycles in combined heat and power applications have offset these trends while improving environmental performance. The U. S. Department of Energy, in partnership with industry, is addressing these development needs. One technology that is showing promise is the medium- 
heating-value gasification system developed by Battelle and licensed to the Future Energy Resources Corporation (FERCO). The first large-scale plant, rated at $40 \mathrm{MW}$, is now in start-up at the McNeil power station of the Burlington Electric Department in Burlington, Vermont. The development path and current status of this technology are discussed.

Keywords: gasification, power generation, gas cleanup, commercialization, medium-Btu gas, McNeil Generating Station, FERCO, Battelle, wood

10. Fehrs, J.E.; Donovan, C.T. Ash from the Combustion of Treated Wood: Characteristics and Management Options. In Proceedings of the Second Biomass Conference of the Americas: Energy, Environment, Agriculture, and Industry; Portland, OR, Aug 21-24, 1995; pp 120-129.

Continued research and development of environmentally acceptable and cost-effective end uses for wood ash are having a significant effect on the ability to use wood and wood waste for fuel. This is particularly true for ash resulting from treated wood combustion. Concern about the contents of ash from wood-containing paint, stain, preservatives, or other chemicals is one of the largest regulatory barriers to its use as a fuel. This paper explains the types of "clean, untreated" and "treated" wood that are likely to produce ash that can be beneficially used and also presents preliminary results from a study sponsored by the New York State Energy Research and Development Authority (NYSERDA) on ash characteristics and end uses. This study sampled and analyzed ash generated during test burns of five treated wood wastes at an 18-MW woodfired power plant and describes existing and potential end uses for untreated and treated wood ash.

Keywords: wood, utilization, creosote-treated, pentachlorophenol-treated, CCA-treated, particleboard/plywood, construction and demolition (C\&D or C/D), flowable fill

11. Hower, J.C.; Robertson, J.D.; Roberts, J.M. Petrology and Minor Element Chemistry of Combustion By-Products from the Co-Combustion of Coal, Tire-Derived Fuel, and Petroleum Coke at a Western Kentucky Cyclone-Fired unit. Fuel Process. Technol. 2001, 74, 125-142.

A western Kentucky power plant conducted a series of test burns with coal-tire-derived fuel (TDF) and coal-TDF-petroleum coke blends. Collections of fuel, fly ash, and bottom ash/slag were made from the cyclone-fired unit under four fuel combinations: coal, coal-ca. $1 \% \mathrm{TDF}$, coal-ca. 3\% tdf, and coal-ca. 3\% tdf-petroleum coke. Fly ash carbons derived from the three fuel types can be distinguished, allowing an assessment of the impact of co-combustion on fly ash quality. While certain aspects of the ash chemistry are distinctive, Zn increasing in TDFderived fly ash and $\mathrm{Ni}$ and $\mathrm{V}$ increasing in petroleum coke-derived fly ash, changes in the coal source between sampling dates complicate the assessment of the chemistry.

Keywords: coal; tire-derived fuel; petroleum coke; Kentucky; fly ash, bottom ash, minor elements, trace elements, V, Ni, Zn 
12. Hughes, E.; Tillman, D. Biomass Cofiring: Status and Prospects 1996; EPRI Item No. SP-107679; Project WO4134-04 (abstract and slides discussing paper only).

Cofiring of biomass in coal-fired boilers has been tested and demonstrated in a number of utility installations. All types of combustion technologies have been used to cofire biofuels with coal, including cyclone boilers, wall-fired and tangentially fired pulverized coal boilers, fluidized-bed boilers, and stoker-fired boilers. Capacities used in cofiring tests and commercial applications have ranged from 50 to $>500 \mathrm{MW}$. Supporting these tests and demonstrations have been fundamental studies and experiments on biofuel safety issues, blended biofuel-coal storage and transport, pulverizer issues, fuel chemistries associated with blending, and related concerns. This activity in cofiring has resulted from utility interest in customer service and customer support in a deregulated utility environment, the potential for niche situations where blending of biofuel achieves fuel cost savings, and the potential for environmental benefit (e.g., $\mathrm{NO}_{\mathrm{x}}, \mathrm{SO}_{2}$, and fossil $\mathrm{CO}_{2}$ reductions). The cofiring programs have demonstrated that biofuel use, with coal, in large utility boilers can be beneficial for both the utility and its customers. Further, the cofiring programs have led to the development of a significant database concerning biofuel properties, boiler performance when cofiring biofuels, and combustion mechanisms when cofiring biofuels with coal. This database has been coupled with computer programs to evaluate certain issues associated with blending, such as ash behavior related to slagging or fouling. The cofiring programs have also defined certain issues that remain unresolved, at least in part. These issues include 1) the influence of cofiring on ash properties and fly ash sales; 2) the influence of cofiring on boiler slagging and fouling problems; 3 ) the influence of fuel blending on pulverizer performance; 4) the maximum percentage of cofiring as a function of materials handling and combustion technologies; and 5) the required characteristics of biofuel particles to achieve defined project-specific goals such as avoiding derate, achieving dispatch, achieving $\mathrm{NO}_{\mathrm{x}}$ control, producing a coproduct from oversized particles, and otherwise meeting customer service, environmental, and economic goals.

Keywords: cofiring, biofuel, fly ash, boilers, coal, $\mathrm{NO}_{\mathrm{x}}, \mathrm{SO}_{2}, \mathrm{CO}_{2}$

13. Introductory Background Information Summary on Hog Fuel Boiler Flyash for the Weyerhaeuser/ECAP Panel on Wood-Based Flyash Utilization Working Session. Seattle/Tacoma, WA, Nov. 27 - Dec. 2, 1995.

Sources of hog fuel boiler fly ash, fly ash composition, and fly ash physical properties and additional chemical properties are given in this summary for the Weyerhaeuser/ECAP Panel on Wood-Based Fly Ash Utilization. A diagram of a wood waste-fired boiler is also given.

Keywords: Weyerhaeuser, fly ash, hog fuel, boiler, wood

14. The Irland Group; Dames \& Moore. Assessment of Situation and Potential for Cofiring Coal and Biomass in Energy Facilities; Final Report to the Council of Great Lakes Governors, Inc., Great Lakes Regional Biomass Energy Program; Great Lakes Region, March 24, 1993. (highlights and page 50 only [page 50 is a table of coal and wood cofiring facilities in the Great Lakes Region with additional plants in Pennsylvania and Maine]). 
This assessment reviews the status and potential for cofiring of biomass with coal in the Great Lakes Region. Topics discussed in this report include an economic and technological review of cofiring-electric utility and nonutility cofiring experiences, cofiring combustor designs, and fuel characteristics and effects on cofiring; effects of cofiring biomass with coal on air emissions-biomass cofiring stack test case studies, published emission factors for coal and wood, and regulatory implications of biomass cofiring; overview of cofiring case studies in the Great Lakes Region; and case studies and their summaries-Blandin Paper Company, Consolidated Papers, Inc., Northern States Power Co. (French Island Plant), Duluth Steam (Lake Superior Paper Industries), Northern States Power Company (Bay Front Plant), P.H. Glatfelter Company, Potlatch Corporation (Northwest Paper Division), Tes Energy Co-Generation Facility, and Traverse City Light \& Power.

Keywords: cofiring, coal, wood, emissions, regulations, case studies, Great Lakes Region

15. Levie, B.; Meyer, D.; Tormey, M. Ash Quantification and Characterization Study; Phase II Report for California Integrated Waste Management Board Contract IWM-C081; R. W. Beck: Denver, CO, May 1994.

This report includes the procedures used to sample, test, and analyze the ash streams of three municipal solid waste (MSW), two medical waste, and ten biomass combustion facilities in California. It also includes discussions of ash test results from these facilities; potential useful applications for ashes; and recommendations for use and or ways to improve the usefulness of the material. Three categories of tests were performed: material, analytical, and agricultural. Facility reports containing sampling procedures and test results from individual facilities participating in this study are provided in the appendices.

Keywords: California, municipal solid waste, medical waste, biomass waste, fluidized bed, grate, characterization, fly ash, bottom ash, toxicity, utilization, feedstock, California Integrated Waste Management Board

16. Narodoslawsky, M.; Obernberger, I. From Waste to Raw Material-The Route from Biomass to Wood Ash for Cadmium and Other Heavy Metals. J. Haz. Mater. 1996, 50, 157-168.

Ash from energetic utilization of biomass contains nutrients like calcium, potassium, and phosphorus that should be recycled to forest or agricultural soils, thus closing not only the carbon cycle but also the fluxes of mineral materials caused by these technologies. The problem is that the ash also contains heavy metals. Cadmium poses a special risk to the use of wood ash in agriculture. It pollutes a large fraction of the ash generated in a biomass combustion plant, namely the cyclone fly ash and, to an even higher degree, the filter fly ash or (where flue gas condensation is installed) the condensation sludge. A medium-term solution to the recycling of solid residues from biomass combustion is blending cyclone fly ash and bottom ash and using the 
mixture in agriculture. Although a large part of nutrients might be recycled in this manner, care must be taken of the relatively high amount of cadmium in this material.

A new technology currently under development takes advantage of the different temperatures in a biomass combustion plant. This technology enables concentration of cadmium (and other volatile heavy metals) in a very small portion of the whole ash flux from a plant, and the concentrations of environmentally relevant substances in the remainder of the ash is kept low. In this manner, wood ash from the process industry or district heating systems might be transformed from waste to raw material for agricultural use.

Keywords: combustion, wood, cadmium, heavy metal, fertilizer, bottom ash, fly ash, agriculture

17. Obernberger, I. Characterisation and Utilization of Ashes from Biomass Combustion Plants. In Proceedings of the 8th European Conference on Biomass for Energy, Environment, Agriculture and Industry, Vienna, Austria, Oct 1994; ADEME (ed): Paris, France, 1994.

The objective of this research is to address the following: 1) what the chemical compositions of wood ashes and the fluxes of the inorganic elements from the biomass fuel to the differently produced ash fractions look like, 2) where to choose the cutpoint for separating the mentioned side stream with greatest ecological efficiency, 3) how a sustainable utilization of the recoverable part of wood ash can be achieved, and 4) which technological aims for the future development of biomass combustion plants can be derived from the research results.

To address the issues outlined above, comprehensive ash examinations covering their chemical compositions (concentrations of nutrients and contaminants) and their physical characteristics (surface structures, bulk densities) were carried out. Eight detailed material flux analyses of biomass combustion plants for the inorganic elements from the biomass to the ash fractions produced were also calculated.

Keywords: wood, bottom ash, cyclone fly ash, filter fly ash, heavy metals, organic, Austria, characterization, flux analysis, inorganic

18. Obernberger, I.; Biedermann, F.; Widmann, W.; Riedl, R. Concentrations of Inorganic Elements in Biomass Fuels and Recovery in the Different Ash Fractions. Biomass Bioenergy 1997, 12 (3), 211-224; S0961-9534(96)00051-7.

Inorganic elements and compounds in biomass fuels influence the combustion process and the composition of the ashes produced. Comprehensive test runs were carried out in several biomass combustion plants equipped with different combustion technologies and using various biomass fuels (wood chips, bark, straw, and cereals). During continuous observation periods of at least two days, samples of the biomass and the different ash fractions were taken and analyzed. Furthermore, the most important operating data of the plants were recorded. 
The results of the material balances for inorganic elements showed that the concentrations of environmentally relevant heavy metals (especially $\mathrm{Cd}$ and $\mathrm{Zn}$ ) in biomass ashes increase with decreasing precipitation temperature and particle size. This effect is independent of the biofuel used. Consequently, a major requirement for a sustainable ash utilization is a fractionated heavy metal separation, distinguishing between different fly ash fractions and taking the temperature of fly ash precipitation into consideration for new furnace technologies. Research has also shown that straw and cereals, as well as their ashes, contain significantly lower amounts of heavy metals than woody biofuels and wood ashes. The same principles pointed out for environmentally relevant heavy metals are also valid for $\mathrm{K}, \mathrm{Na}, \mathrm{Cl}$, and $\mathrm{S}$. The high concentrations of these elements in the filter fly ash as well as in the boiler fly ash are of great relevance for reactions that can take place in the boiler section where the flue gas is subjected to a considerable temperature gradient which is accompanied by chemical reactions, phase transitions, and precipitation processes that can support or initiate fouling and corrosion. These effects are of special importance for biofuels that are rich in alkali metals and $\mathrm{Cl}$ such as straw and cereals.

Keywords: combustion, inorganic elements, ash composition, utilization, heavy metal fractionation, fouling, corrosion

19. Obernberger, I.; Dahl, J.; Brunner, T. Formation, Composition, and Particle Size Distribution of Fly-Ashes from Biomass Combustion Plants. In Proceedings of the 4th Biomass Conference of the Americas, Oakland, CA, Sept 1999; Elsevier Science Ltd. (Ed.): Oxford, UK, 1999; pp 1377-1385.

In Austria, the share of thermal biomass utilization in total energy production has steadily increased during recent years, and this trend is expected to continue. Gaseous emissions of biomass combustion plants have fallen to a rather low level, but particulate emissions remain an unsolved problem. Particulate emissions can be divided into coarse fly ash particles entrained with the flue gas from the fuel bed and aerosols formed by nucleation and condensation of species vaporized during combustion. Although the concentration of coarse fly ash particles mainly depends on the load of the furnace and the combustion technology used, the fuel composition and the temperature of combustion influence the amount of aerosols formed. In this paper, the most current knowledge about fly ash and aerosol formation as well as behavior in biomass combustion and flue gas-cleaning units will be presented and explained. A better understanding of the processes and mechanisms governing aerosol formation and growth should assist in the discovery of modified combustion technologies that reduce the amount of aerosols formed and also lead to less aerosol emissions and corrosion damage.

Keywords: aerosol, fly ash, emissions, flue gas, environment, health, K, fluidized bed, fixed bed, grate furnace, Austria

20. Plasynski, S.I. An Overview of DOE’s Biomass Cofiring Program: Opportunities, Challenges, and Results. Presented at the ACAA-USWAG Workshop on Management \& Use of CCPs, Nashville, TN, June 5, 2001. 
This slideshow presentation includes a summary of past testing completed in the DOE Biomass Cofiring Program, testing factors and results, proximate and ultimate analysis of various biofuels and coals, ash elemental analysis of biofuels and coal, a results table of fly ash quality during the biomass cofiring tests at Michigan City, trace metal concentrations in biomass, and a list of biomass project titles and awardees.

Keywords: DOE, cofiring, testing, biofuel, proximate analysis, ultimate analysis, elemental analysis, fly ash, trace metal

21. Rughani, J.; Diebel, J.; McGinnis, G.; St. John, W. Characterization of Wood Ash and Its Regulations for Land Applications in Great Lakes Region. In Proceedings of the 2nd Biomass Conference of the Americas: Energy, Environment, Agriculture, and Industry; Portland, OR, Aug 21-24, 1995; 168-177.

A serious barrier to the increased use of biomass fuels is the problem of ash disposal. The most cost-effective way to dispose of wood ash is to apply/spread it on agricultural land. All the Great Lakes states studied in this report approved the land application of wood ash. However, each state had different analytical requirements for the wood ash characterization to obtain a permit for land application. This report summarizes the state regulatory status of wood ash and agencies and persons to contact regarding the permitting procedures for land application. Also summarized are various types of analyses required for wood ash and soil before the land application permit is approved.

Wood ash samples were obtained from 45 industrial boilers throughout the Great Lakes states. The ash samples were then analyzed to document the range of properties, including elemental composition, $\mathrm{pH}$, chlorides, conductivity, carbonates, sulfates, ammonia nitrogen, nitrate nitrogen, total Kjeldahl nitrogen, ash content and heavy metal concentrations. A wide variation in the wood ash results was observed. No apparent correlation was found with the wood ash results generated between the different types of fuels, species, fuel mix, burners, large or small generators, etc.

Keywords: disposal, agriculture, regulations, Great Lakes Region, wood, heavy metals, soil amendment

22. Segrest, S.A.; Rockwood, D.L.; Stricker, J.A.; Green, A.E.S. Biomass Cofiring with Coal at Lakeland Utilities; Final Report (Sept 1997 - July 1998) for Tennessee Valley Authority Contract No. 97RKW-219287; The Common Purpose Institute; University of Florida: FL, July 31, 1998 (table of contents and abstract only).

This project evaluates the major agricultural, power plant engineering, and business development issues associated with energy crop biomass (i.e., "closed loop”) cofiring with coal at Lakeland Utilities' McIntosh-3 unit in Polk County in central Florida. McIntosh-3 (a Babcock and Wilcox pulverized coal [pc], wall-fired boiler design) is a large power plant (365 MW) operating as a base load facility (i.e., a historical availability/capacity factor of $80+\%$ ). It is unique among pc power plants, designed to allow some cofiring of refuse-derived fuel (RDF). 
Generally, coutilization of biomass with coal in a preexisting pc boiler steam turbine facility can proceed by 1) direct cofiring or 2) indirect cofiring using another thermal processing system and feeding its gaseous, liquid or solid products into the boiler. Prior direct cofiring studies are listed, including a similar wall-fired burner arrangement for cofiring biomass.

Since McIntosh-3's limit of 2\% RDF cofiring impedes effective direct cofiring of biomass or RDF-biomass combined, five ways of overcoming this limitation are identified. The mechanical processing necessary to feed the biomass through the RDF channel is also considered. For indirect cofiring technologies, lists of six external and two internal gasifier vendors are given along with comments on performance. A brief discussion of advanced gasifiers for directly firing combustion turbines is given. The appendix contains an extended biomass gasifier vendor contact list and three tables summarizing a prior detailed evaluation of municipal solid waste or RDF thermal processors that might also be adapted for biomass. In addition, reviews of potential economic and market incentives for biomass cofiring were performed.

Keywords: cofiring, coal, Lakeland Utilities, McIntosh-3, gasifier, municipal solid waste, refusederived fuel (RDF), thermal processor, agriculture

23. Someshwar, A.V. Wood and Combination Wood-Fired Boiler Ash Characterization. Presented at the Symposium on Land Application of Wood-Fired and Combination Boiler Ashes, Auburn University; J. Environ. Qual., in press, 1995.

This paper reviews the available data on macroelement concentrations, trace and heavy metal concentrations, and concentrations of organics (including PAHs, chlorobenzenes, chlorophenols, PCBs, and PCDD/Fs) in ashes from wood residue combustion in industrial boilers. Trace and heavy metal concentrations in wood ashes are compared with other potential soil amendments such as coal ash, sewage sludge, waste treatment plant pulp mill sludge, and agricultural limestone. The impact of combination firing of wood residue with coal, sludge, and other common solid fuels available in the pulp and paper industry upon ash metal concentrations is also presented. PCDD/F levels in ashes resulting from 100\% inland wood residue combustion, salty wood combustion, bleached mill sludge combustion with wood residue and residential wood combustion are reviewed. Wood ash concentrations of metals are seen to be comparable to other potential soil amendments but much lower than those in sewage sludges. Ash PCDD/F contents are seen to be influenced by extraneous sources of chloride in the wood fuel.

In addition, ash composition data resulting from bleached mill sludge burning (along with wood residue) are presented. Ash compositions, both macro- and microelements, are compared with coal ashes and limestone. Microelements in wood ashes are also compared with other potential soil amendments such as sewage and pulp mill sludges.

Keywords: wood, trace metal, heavy metal, microelement, macroelement, coal, limestone, soil amendment, sludge, chloride, organics, PCDD, PCDF, dioxins, furans, organics

24. Sturdy Engineering Corporation; New Concept Engineering. Use of Wood Fly Ash as a 
Cement Concrete Admixture; Testing Report for Second Arrow Project; Mount Vernon, WA; Bellingham, WA.

In this report, the use of wood-fired boiler ash in cement concrete as a replacement for a portion of portland cement in concrete is explored. Concrete cylinders with wood boiler ash replacements were made, and their compression test results were evaluated.

Keywords: wood fly ash, coal fly ash, admixture, cement, concrete, testing

25. Wang, S.; Llamozas, E.; Miller, A.B.; Baxter, L.L.; Fonseca, F.F.; Lucas, W.K. The Effects of Adding Biomass Fly Ash to Concrete. Proceedings of the 15th International American Coal Ash Association Symposium on Management \& Use of Coal Combustion Products (CCPs) [CD-ROM]; St. Petersburg, FL, Jan 27-30, 2003; Paper 93.

Class C and Class F fly ashes have been standardized for industrial use in concrete. Other types of fly ashes, such as those from wood, grass, and various combinations of cofired biomass and coal have not yet been accepted as standardized additives. In an effort to standardize a variety of mixtures for industrial uses in concrete, a set of experiments was conducted on distinct combinations of cofired, wood, and biomass fly ashes in concrete mixtures to determine the effects on slump, air content, flexure, compression, rapid chloride permeability, freeze-thaw, and setting time.

Keywords: admixture, fly ash, concrete, wood, cofiring, coal, testing 